\title{
Accessibility of Bay Area Rail Transit Stations: An Evaluation of Opportunities for Transit Oriented Development
}

\author{
A Thesis \\ presented to \\ the Faculty of California Polytechnic State University, \\ San Luis Obispo
}

\author{
In Partial Fulfillment \\ of the Requirements for the Degrees \\ Master of Science in Engineering/Master of City and Regional Planning \\ (Transportation Planning Specialization) \\ by \\ Kevin M. Fang
}


(C) 2009

Kevin M. Fang

ALL RIGHTS RESERVED 


\section{CommitTee Membership}

TITLE:

AUTHOR:

DATE SUBMITTED:

COMMITTEE CHAIR:
Accessibility of Bay Area Rail Transit Stations:

An Evaluation of Opportunities for

Transit Oriented Development

Kevin M. Fang

September 21, 2009

Dr. Cornelius Nuworsoo

Assistant Professor of

City and Regional Planning

Dr. Kelly Main

Assistant Professor of

City and Regional Planning

Dr. Anurag Pande

Assistant Professor of

Civil and Environmental Engineering 
Accessibility of Bay Area Rail Transit Stations:

An Evaluation of Opportunities for Transit Oriented Development

Kevin M. Fang

Many groups have been pushing for a shift from automotive oriented transportation and land use, to transit-oriented transportation and land use. These groups have many valid reasons. However, just as it is fair to point out issues about auto travel, so too is it fair to see how transit performs at meeting certain goals. This paper examines the important characteristic of accessibility afforded to travelers. This is quantified through the calculation of accessibility indices for stations, for the specific case of two existing rail systems and four proposed rail extensions in the San Francisco Bay Area.

As a whole, the four extensions investigated increase regionwide rail accessibility by 18.5 percent, not an insignificant increase. However, the new stations are on average less accessible than their existing counterparts. Two of the four extensions perform well on accessibility measures, either their stations have high accessibility, or jobs around them contribute to high accessibility for nearby stations. The other two extensions however perform poorly on accessibility measures. In a time of limited resources, the accessibility results clearly indicate how the four extensions should be prioritized. The more successful extensions have good access to activity centers. Extensions having good connectivity with other lines can also enhance accessibility if providing significant travel time savings. 


\title{
ACKNOWLEDGEMENTS
}

\author{
Dedicated to \\ Professor Edward C. Sullivan \\ Associate Dean \\ College of Engineering \\ 1944-2009
}

A true gentleman and mentor

Was to be a member of this thesis committee

Very special thanks to:

The Committee,

Professor Nuworsoo, Professor Main, and Professor Pande

For their time and expertise, reading and commenting

on this ever-changing, never-ending document

David Yun

Department of Forestry and Natural Resources

For teaching well the fundamentals of Geographic Information Systems

The students of

City and Regional Planning 214

Spring 2009 


\section{TABLE OF CONTENTS}

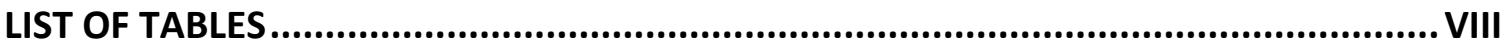

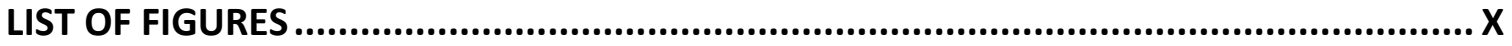

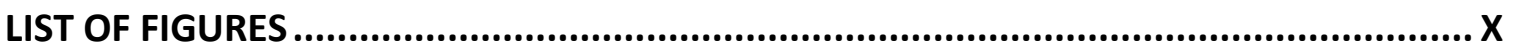

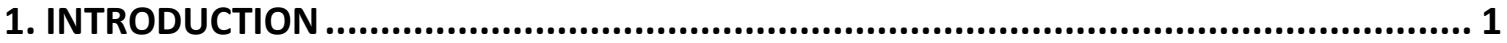

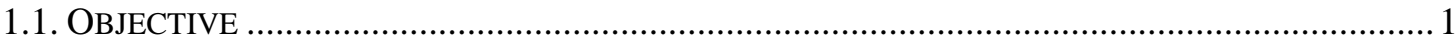

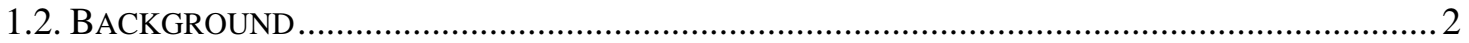

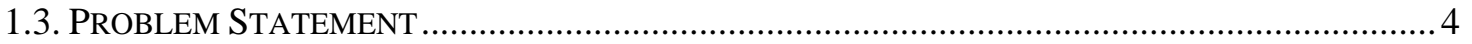

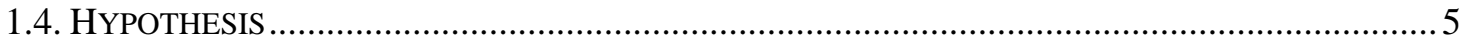

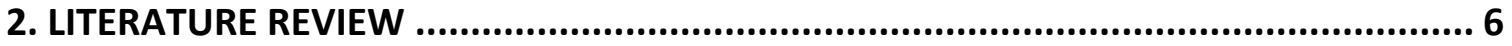

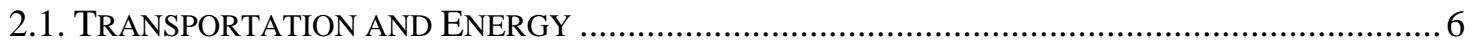

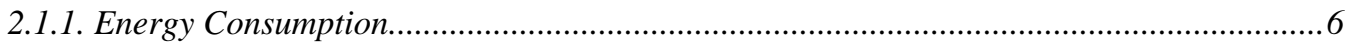

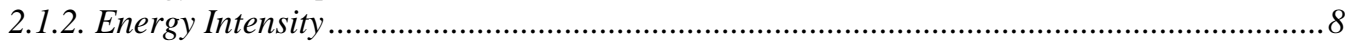

2.1.3. Carbon Dioxide Generation .........................................................................................12

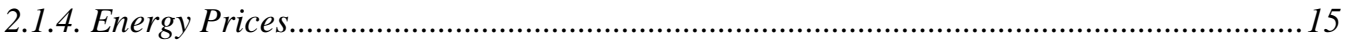

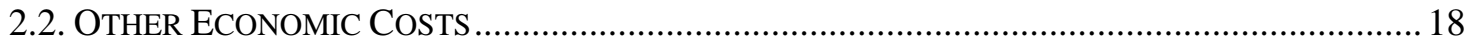

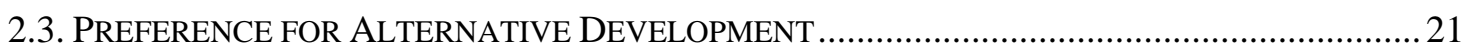

2.3.1. Boston and Atlanta Case Study .......................................................................................21

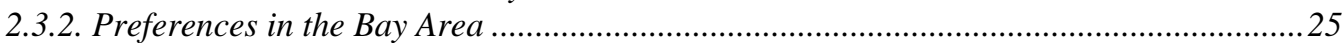

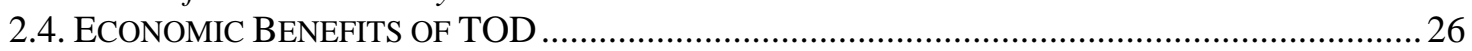

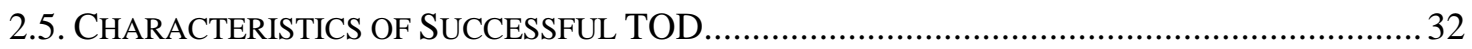

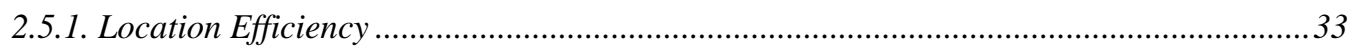

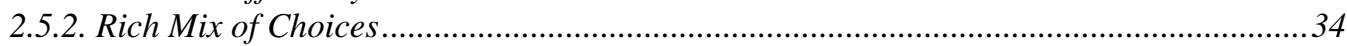

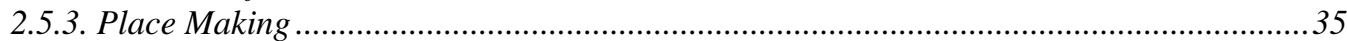

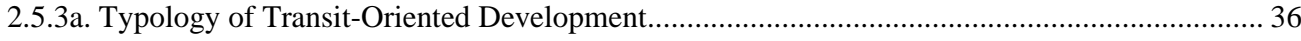

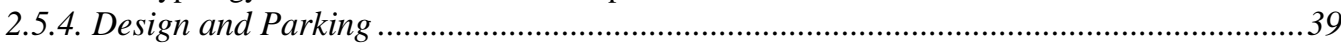

2.6. USING ACCESSIBILITY AS MEASURE FOR TOD OPPORTUNITIES.......................................... 42

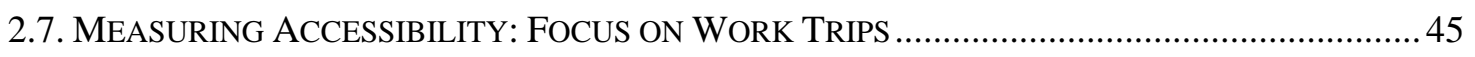

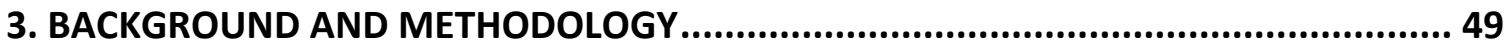

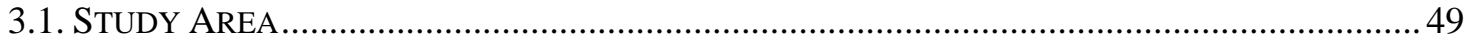

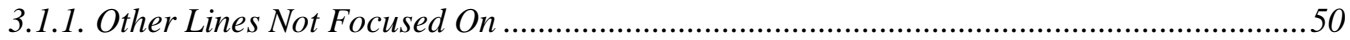

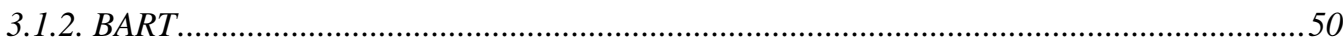

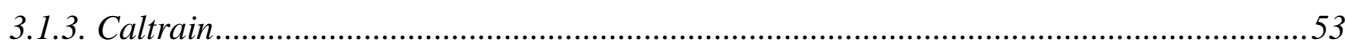

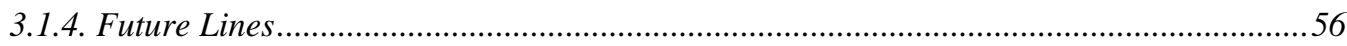

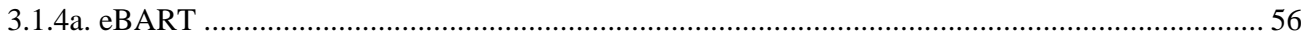

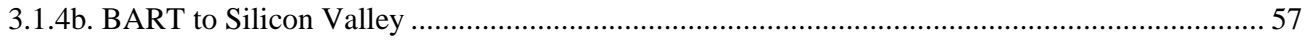

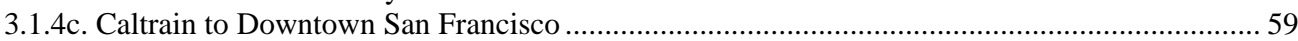

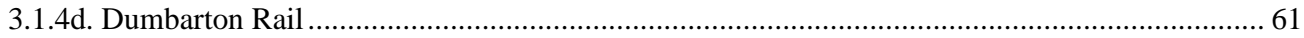

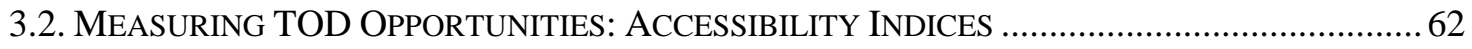

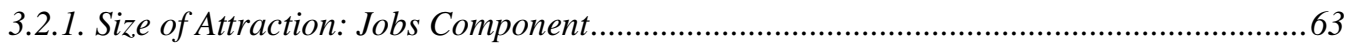

3.2.2. Friction Factor Component ………………....................................................................69

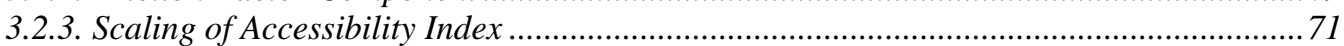

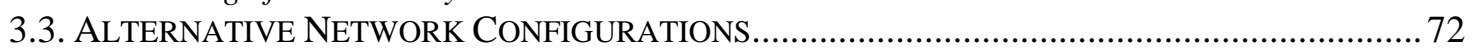

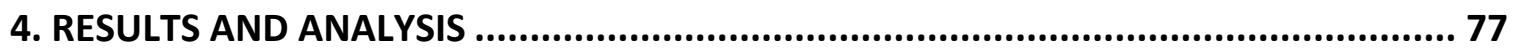

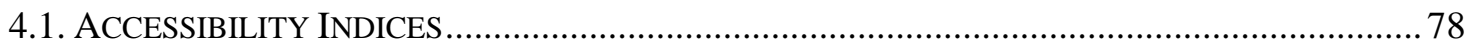


4.1.1. Accessibility Indices for Alternative Network Configuration A .........................................78

4.1.2. Accessibility Indices for Alternative Network Configuration B .........................................83

4.1.3. Accessibility Indices for Alternative Network Configuration C .........................................87

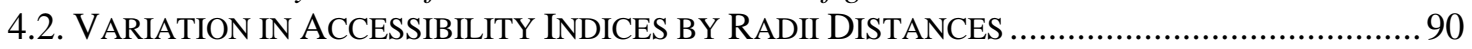

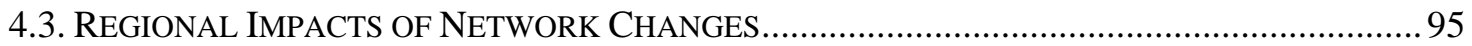

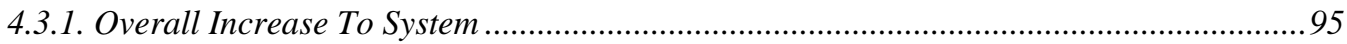

4.3.2. Impacts on Accessibility by Sub-Regional Area Type .........................................................97

4.3.3. Impacts on Accessibility by Sub-Regional Geographic Area...........................................101

4.3.3a. Increases from Alternative Network Configurations A to B................................................... 104

4.3.3b. Increases from Alternative Network Configurations A to C ………………………………..... 107

4.3.3c. Increases from Alternative Network Configurations B to C.................................................... 110

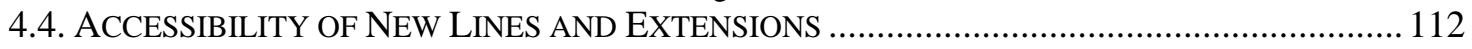

4.4.1. Accessibility Indices and Relative Ranks of Stations Along Extensions..........................112

4.4.2. Accessibility Benefit to Specific Lines................................................................................114

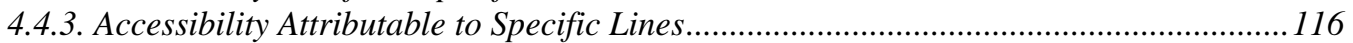

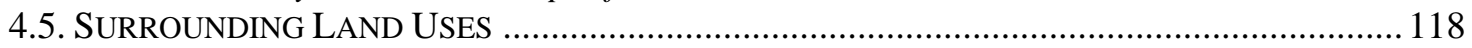

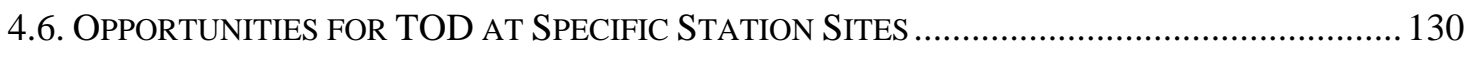

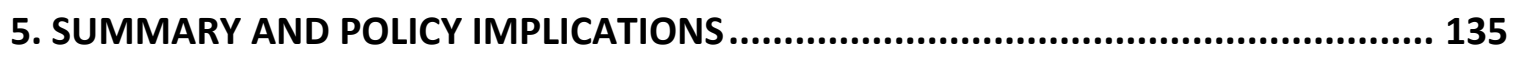

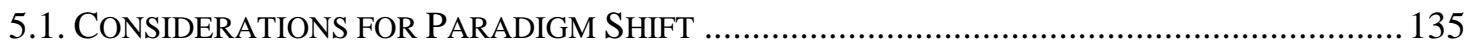

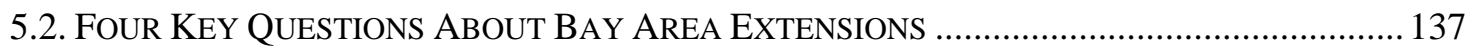

5.2.1. Accessibility of Existing Stations .................................................................................138

5.2.2. Accessibility of Stations along Extensions .........................................................................139

5.2.3. Increases in Station Accessibility due to Extensions.......................................................139

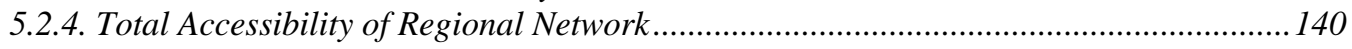

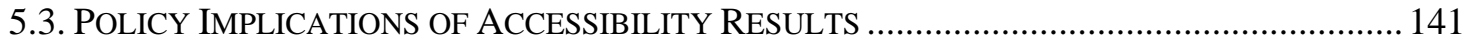

5.3.1. Prioritization of Extensions ..........................................................................................141

5.3.2. Characteristics of More Accessible Extensions ................................................................143

5.3.3. Importance of Transit-Oriented Development Supporting Policies..................................144

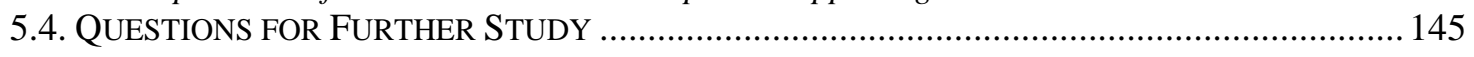

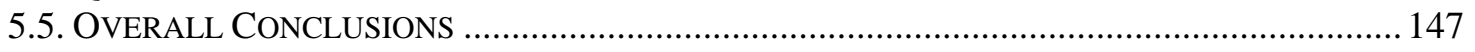

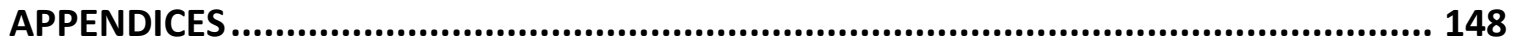

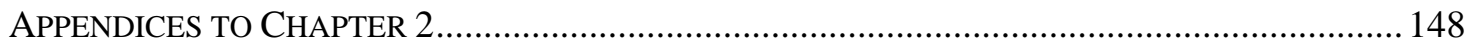

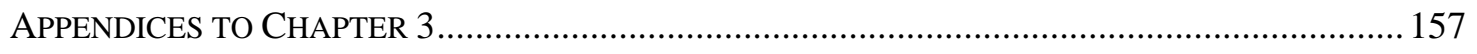

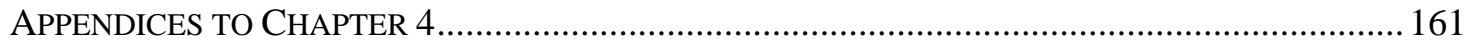

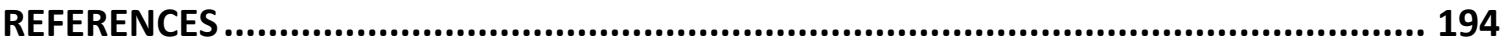

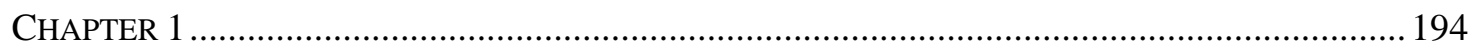

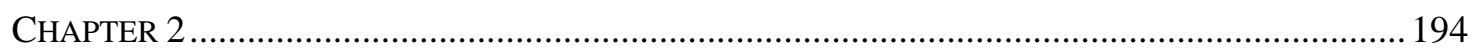

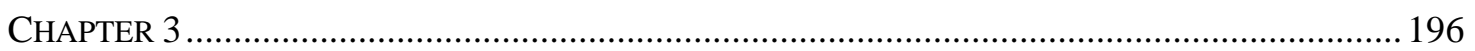

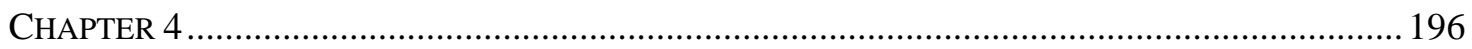

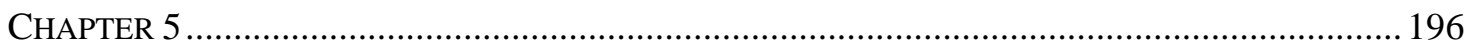




\section{LIST OF TABLES}

Table 2.1 Energy Consumption by Transportation Sector by Source (in Quadrillions of BTUs), 1995-2005.

Table 2.2 Carbon Dioxide Emissions in the Transportation Sector by Energy Source (in

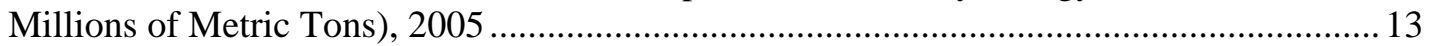

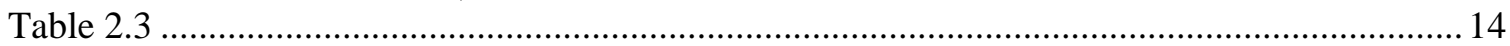

Relative carbon content of different energy fuels (grams of carbon per megajoule of energy

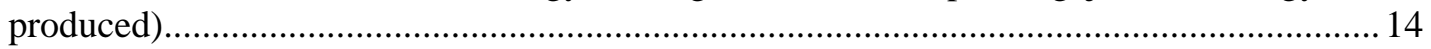

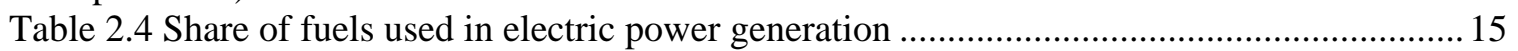

Table 2.5 Projected Water and Sewer Infrastructure under Conventional Development and

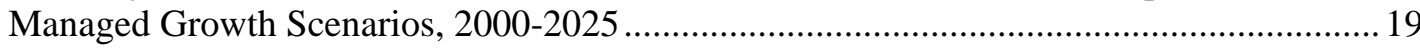

Table 2.6 Projected Local Road Infrastructure under Conventional Development and

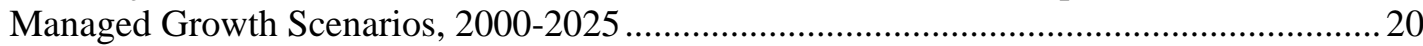

Table 2.7 Projected Fiscal Impact Under Conventional Development and Managed Growth

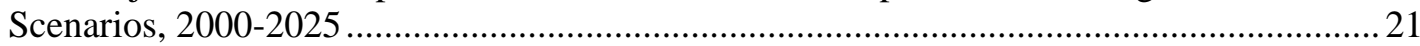

Table 2.8 Neighborhood preference factors, Boston and Atlanta.................................................22

Table 2.9 Where respondents lived (by neighborhood cluster), Boston and Atlanta......................23

Table 2.10 Average Annual Consumer Expenditures (Dollars), 2006 ..........................................26

Table 2.11 Average Annual Transportation Expenditures by Type of Area (Dollars), 2006 ........ 28

Table 2.12 Percent of Consumer Units That Own At Least 1 Vehicle, 2006 ................................29

Table 2.13 Private Vehicle vs. Public Transport Costs in Central Cities and Other Urban

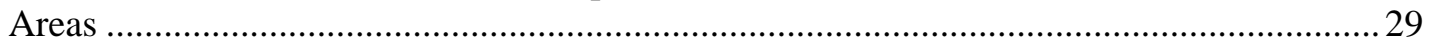

Table 2.14 General Typology of TOD Places Within a Metropolitan Region ............................. 39

Table 2.15 Average Weekday Daily Trips and Person Miles of Travel: San Francisco Bay

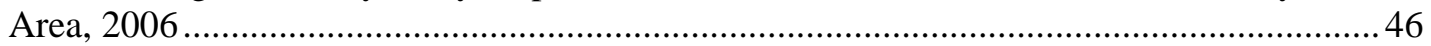

Table 2.16 Average Weekday Daily Trips and Person Miles of Travel: San Francisco Bay

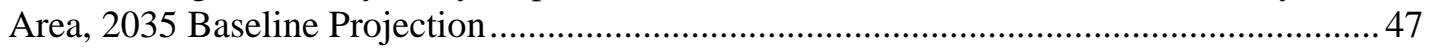

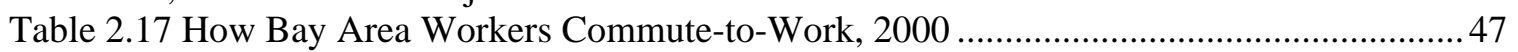

Table 2.18 How Workers Commute To Work For Selected Locations, 2000 .............................. 48

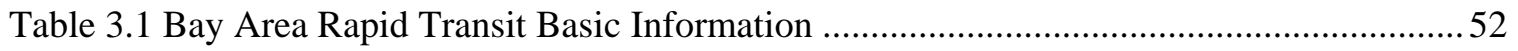

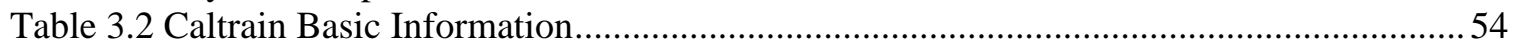

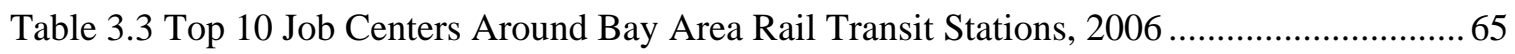

Table 3.4 Smallest 5 Job Centers Around Bay Area Rail Stations, 2006 ....................................65

Table 4.1 Top 20 and Bottom 5 Index Stations - Alternative Network Configuration A ............ 82

Table 4.2 Top 20 and Bottom 5 Index Stations - Alternative Network Configuration B ............ 86

Table 4.3 Top 20 and Bottom 5 Index Stations - Alternative Network Configuration C ............. 89

Table 4.4 Spearman's Rho Values Measuring Variation of Accessibility Index Values

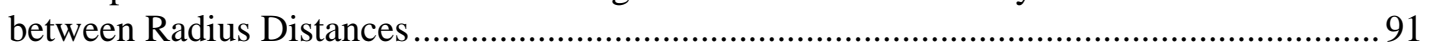

Table 4.5 T-distribution Significance Test for Spearman's Rho Values ......................................92

Table 4.6 Variability In Job Counts Around East and West Dublin/Pleasanton Stations.............. 93

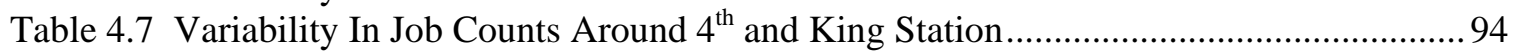

Table 4.8 Systemwide Accessibility and Rates of Change From Alternatives A-C ...................... 96

Table 4.9 Shares of Growth In Accessibility Between Alternative Network Configurations

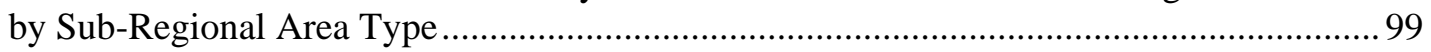

Table 4.10 Shares of Growth In Accessibility Between Alternative Network Configurations

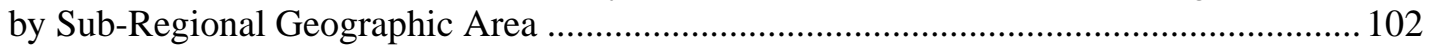

Table 4.11 Top 10 Increases in Accessibility for Stations from Alternative A to B ................... 105

Table 4.12 Top 10 Increases in Accessibility for Stations from Alternative A to C ................... 108 
Table 4.13 Top 10 Increases in Accessibility for Stations from Alternative B to C 110

Table 4.14 Accessibility Indices and Relative Ranks of Stations Along Extensions

Table 4.15 Shares of Growth In Accessibility Benefit By Line ...

Table 4.16 Shares of Growth In Accessibility Generation By Line 117

Table 4.17 Top 20 Stations by Percent of Station Areas That Are Low Density Res. Within $1 / 4$ Mile

Table 4.18 Top 20 Stations by Percent of Station Areas That Are Low Density Res. Within $1 / 2$ Mile

Table 4.19 Percent of Station Areas That Are Low Density Residential Within 1 Mile .............127

Table X2.1 Energy Use By Sector, 1949-2007 (Billions of BTUs)............................................ 148

Table X2.2 Energy Intensity by Passenger Mode (in BTU per Passenger Miles Traveled), 1994-2006

Table X2.3 Calculation of Energy Intensity for Heavy Rail and Light Rail............................... 150

Table X2.4 Calculation of Energy Intensity for Commuter Rail ................................................. 151

Table X2.5 Carbon Dioxide Emissions by Economic Sector (Millions of Metric Tons of $\mathrm{CO}_{2}$ ), 1980-2006. 152

Table X2.6 Calculation of relative carbon content of different energy fuels.............................. 153

Table X2.7 Real Gas Prices (in 2008 Dollars), 1919-2010. 154

Table X2.8 Real Gas Prices (in 2008 Dollars) and Vehicle Miles Traveled, January 2007 April 2009 156

Table X3.1 Job Counts Within One Quarter and One Half Mile of Existing or Potential Rail Stations, 2006

Table X3.2 Calibrated Friction Factors from MTC BAYCAST-90 Travel Model ..................... 159

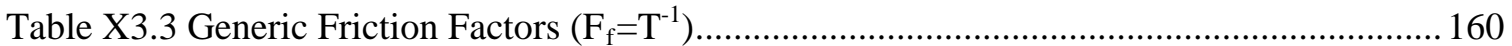

Table X4.1 Accessibility Indices - Alternative Network Configuration A ................................ 161

Table X4.2 Accessibility Indices - Alternative Network Configuration B ................................. 164

Table X4.3 Accessibility Indices - Alternative Network Configuration C ................................. 167

Table X4.4 Accessibility Indices and Ranks - Alternative Network Configuration A ............... 170

Table X4.5 Accessibility Indices and Ranks - Alternative Network Configuration B................. 172

Table X4.6 Accessibility Indices and Ranks - Alternative Future C ........................................ 175

Table X4.7 Spearman's Rho Significance Test for Station Rankings at Different Distance Radii 178

Table X4.8 Increase in Accessibility from Alternative Network A to Alternative Network B ... 179 Table X4.9 Increase in Accessibility from Alternative Network A to Alternative Network C ... 181 Table X4.10 Increase in Accessibility from Alternative Network B to Alternative Network C . 183

Table X4.11 Percent of Station Surrounding Areas That Are Low Density Res. - 1/4 Mile Radius

Table X4.12 Percent of Station Surrounding Areas That Are Low Density Res. - 1/2 Mile Radius

Table X4.13 Percent of Station Surrounding Areas That Are Low Density Residential - 1 Mile Radius

Table X4.14 Generalized Opportunities for TOD at Individual Stations 191 


\section{LIST OF FIGURES}

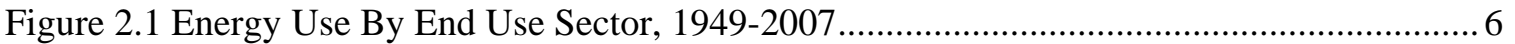

Figure 2.2 Energy Intensity by Passenger Mode, 1994-2006 ...................................................

Figure 2.3 Carbon Dioxide Emissions by Economic Sector, 1980-2006 .................................... 13

Figure 2.4 Real Gasoline Pump Prices: Annual Average, 1919-2010 (in 2008 Dollars) .............. 16

Figure 2.5 Gas Prices and Vehicle Miles Traveled, January 2007-June 2008.............................. 17

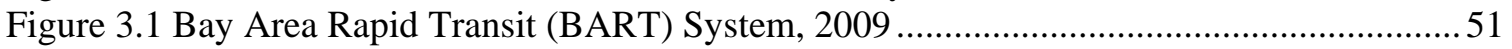

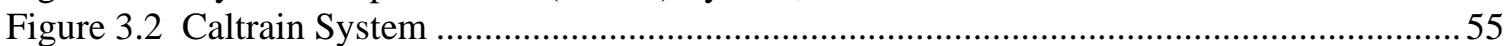

Figure 3.3 Potential Full Build Alignment of eBART System .................................................. 57

Figure 3.4 Proposed BART to Silicon Valley Extension............................................................. 59

Figure 3.5 Proposed Caltrain to Downtown San Francisco Extension .........................................60

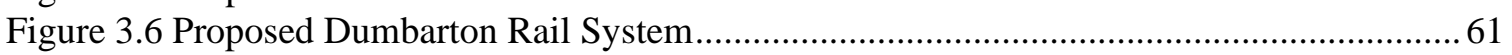

Figure 3.7 Number of Jobs Within One Quarter Mile of Bay Area Rail Stations, 2006 ............... 66

Figure 3.8 Number of Jobs Within One Half Mile of Bay Area Rail Stations, 2006 ................... 67

Figure 3.9 Number of Jobs Within One Mile of Bay Area Rail Stations, 2006 ............................. 68

Figure 3.10 Friction Factors from MTC BAYCAST-90 Travel Demand Study vs. Generic

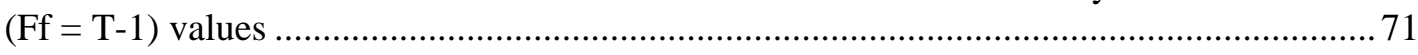

Figure 3.11 Alternative Network A: Existing System - BART and Caltrain ................................. 74

Figure 3.12 Alternative Network B: BART, Caltrain, eBART, BART-Silicon Valley,

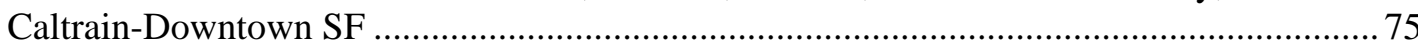

Figure 3.13 Alternative Network C: Alternative B plus Dumbarton Rail .................................... 76

Figure 4.1 Schematic of Connectivity for the Three Alternative Network Configurations ........... 78

Figure 4.2 Accessibility Indices - Alternative Network Configuration A....................................81

Figure 4.3 Accessibility Indices - Alternative Network Configuration B ..................................... 85

Figure 4.4 Accessibility Indices - Alternative Network Configuration C.....................................8 88

Figure 4.5 Stations by Sub-Regional Area Type ....................................................................... 100

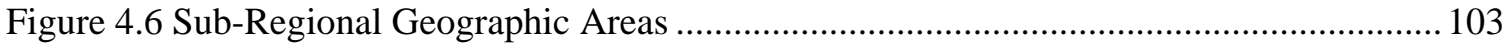

Figure 4.7 Increases in Accessibility for Stations from Alternative A to B................................ 106

Figure 4.8 Increases in Accessibility for Stations from Alternative A to C.................................. 109

Figure 4.9 Increases in Accessibility for Stations from Alternative B to C................................. 111

Figure 4.10 Generalized Land Uses in the San Francisco Bay Area .......................................... 121

Figure 4.11 Percent of Station Areas That Are Low Density Residential Within 1/4 Mile........... 124

Figure 4.12 Percent of Station Areas That Are Low Density Residential Within 1/2 Mile........... 126

Figure 4.13 Percent of Station Areas That Are Low Density Residential Within 1 Mile.............128

Figure 4.14 Generalized Opportunity for TOD at Individual Stations (by Rank Quintile) .......... 134 


\section{INTRODUCTION}

\subsection{Objective}

This study examines the accessibility of the rail transit network in the San Francisco Bay Area and the resulting opportunities for transit-oriented development that this accessibility fosters. Accessibility will be investigated for the existing rail transit network as well as potential future network alignments incorporating four proposed future extensions. The investigation will focus on four key questions:

(a) Whether existing stations are highly accessible and thus good opportunities for transit-oriented development

(b) Whether stations along proposed extensions are highly accessible and thus good opportunities for transit-oriented development

(c) The degree to which existing stations increase in accessibility as a result of extensions to the network

(d) The overall total accessibility of the regional rail network

The spotlight on accessibility and transit-oriented development is driven by the paradigm shift many groups, including transportation planners, land use planners, and community activists, are seeking away from predominantly automobile-oriented transportation and land use, to transit-oriented transportation and land use. Considering this movement, it would be beneficial to see how well transit systems perform, with accessibility being an important goal to look at. Accessibility is important no matter what mode a transportation network comes in. As for the specific case of the San Francisco Bay, it would be helpful to see how potential future investments on transit can impact accessibility and create 
opportunities for transit-oriented development, and where in the region those opportunities might be.

\subsection{Background}

The San Francisco Bay Area is one of the more transit rich regions in the United States, particularly west of the Mississippi. The region is home to 7,203,557 residents (US Census - American Community Survey, 2005-2007) who logged over 21 million trips per weekday in 2006. There are 26 different public transit agencies, including a regional heavy rail system, two commuter rail systems, two light rail systems, ferries, and buses.

This study focuses on larger, inter-city heavy and commuter rail systems which have the potential to carry more passengers and support larger transit-oriented developments. The two existing major inter-city workhorses are the Bay Area Rapid Transit (BART) heavy rail system, and the Caltrain commuter rail system.

BART is a heavy-rail system composed of five lines. BART serves the East Bay, and upper Peninsula areas of the Bay Area. Four of the five lines serve downtown San Francisco, and the fifth line is an intra-East Bay line. All five lines go through Oakland. San Francisco and Oakland are connected via the Transbay Tube, a tunnel that runs under the floor of San Francisco Bay to the north of the Bay Bridge. The five lines are routed on 104 miles of track served by 44 stations. At peak periods, trains operate at headways as short as five minutes. During off-peak periods and weekends, trains operate at headways no longer than 20 minutes. In 2008, BART attracted 357,775 riders per weekday. 
Caltrain serves the west and south sides of San Francisco Bay. Caltrain is a commuter rail system that runs as a single line from San Francisco, through the Peninsula, to San Jose, and southern Santa Clara County. The system does not penetrate the downtown cores of either San Francisco or San Jose, stopping just short in San Francisco and grazing the side of downtown San Jose. The 77 mile system has 33 stations, served by local stop, and express 'Baby Bullet’ trains, which stop at selected higher-volume stations. Different Baby Bullet runs stop at different sets of higher-volume stations. During peak hours, Baby Bullet served stations can see headways between five minutes (atypical - on stations where all Baby Bullets stop) and 30 minutes, and non-Baby Bullet served stations see peak headways of one hour. In 2008, Caltrain attracted 36,993 riders per weekday.

The four new lines evaluated are the BART to Silicon Valley extension, eBART extension, Caltrain to Downtown San Francisco extension, and the Dumbarton Rail project. All four of the extensions have been identified as part of future rail network expansion in the 2035 Bay Area Transportation Plan by the area's regional transportation planning entity, the Metropolitan Transportation Commission (MTC).

eBART extends off the Pittsburg terminus of the BART system. eBART would provide commuter rail service to the Sacramento River Delta area, outer-ring suburbs, in northeastern Contra Costa County. The full build option of the extension includes seven stations out to the small town of Byron. 
BART to Silicon Valley would extend the system from the Fremont terminus through San Jose, to a new terminus in Santa Clara. It would serve both Downtown San Jose, and the San Jose International Airport, via a people mover. The 20.2 mile extension would include seven stations, including two connections with Caltrain at San Jose-Diridon and Santa Clara.

Caltrain to Downtown San Francisco would extend Caltrain, which currently stops short of downtown San Francisco into downtown. The extension would be comprised of only one additional station at a redeveloped Transbay Center intermodal facility.

Dumbarton Rail would re-introduce commuter rail across the presently abandoned Dumbarton Rail Bridge, just south of the vehicular Dumbarton Bridge that crosses San Francisco Bay. The project would connect communities in the mid-East Bay between Oakland and San Jose, with those in the mid-Peninsula between San Francisco and San Jose. Three new stations would be put into service between existing BART and Caltrain stations.

\subsection{Problem Statement}

Previous research has identified many ills regarding predominantly auto-oriented transportation and land use. These include environmental, economic, social/equity, and consumer preference issues. In light of these facts, advocates call for expansion of transit infrastructure.

However, there should not be a shift to transit just for the sake of having transit. Public transit is subsidized in the US, a fact that energizes opponents of transit capital 
expansion. It is prudent when transit investments are made that the infrastructure and service provided work well. The investigation of accessibility and transit-oriented development, and the other research that this report builds on, can help shed light on the potential impacts of investments and priorities that should be accorded various improvements.

\subsection{Hypothesis}

Accessibility is related to the size or number of activity centers that one can reach from a given place, and inversely related to the cost, whether it is time or distance or some other cost, of reaching those centers. It can thus be generally expected, that the highest accessibility, and thus best opportunities for transit-oriented development will be found in places very close to large activity centers. The more activity centers a traveler can reach from a place, the higher the accessibility, so it can also be reasonably expected that the more complete and far-reaching a network is, the higher the accessibility as well.

Extensions, by virtue of encompassing previously un-served activity centers, however big or small, should by default increase accessibility by some amount. It would seem reasonable that extensions that are in high activity areas, or that close loops and make new connections between lines, thus helping form a more complete network, should result in significantly higher accessibility. Conversely, extensions that go out into the fringe, into lower activity areas, or that spur outward only, and thus are connected at just one end, should result in more marginal gains in accessibility. The analyses in this study investigate this hypothesis. 


\section{LITERATURE REVIEW}

\subsection{Transportation and Energy}

\subsubsection{Energy Consumption}

The transportation sector is a major consumer of energy, with 29 quadrillion BTU's of energy used in 2007 (Energy Information Administration, 2008). Transportation was thus the second highest end-use sector consumer of energy out of four main economic sectors (see Figure 1 and Appendix, Table X2.1).

\section{Figure 2.1}

Energy Use By End Use Sector, 1949-2007

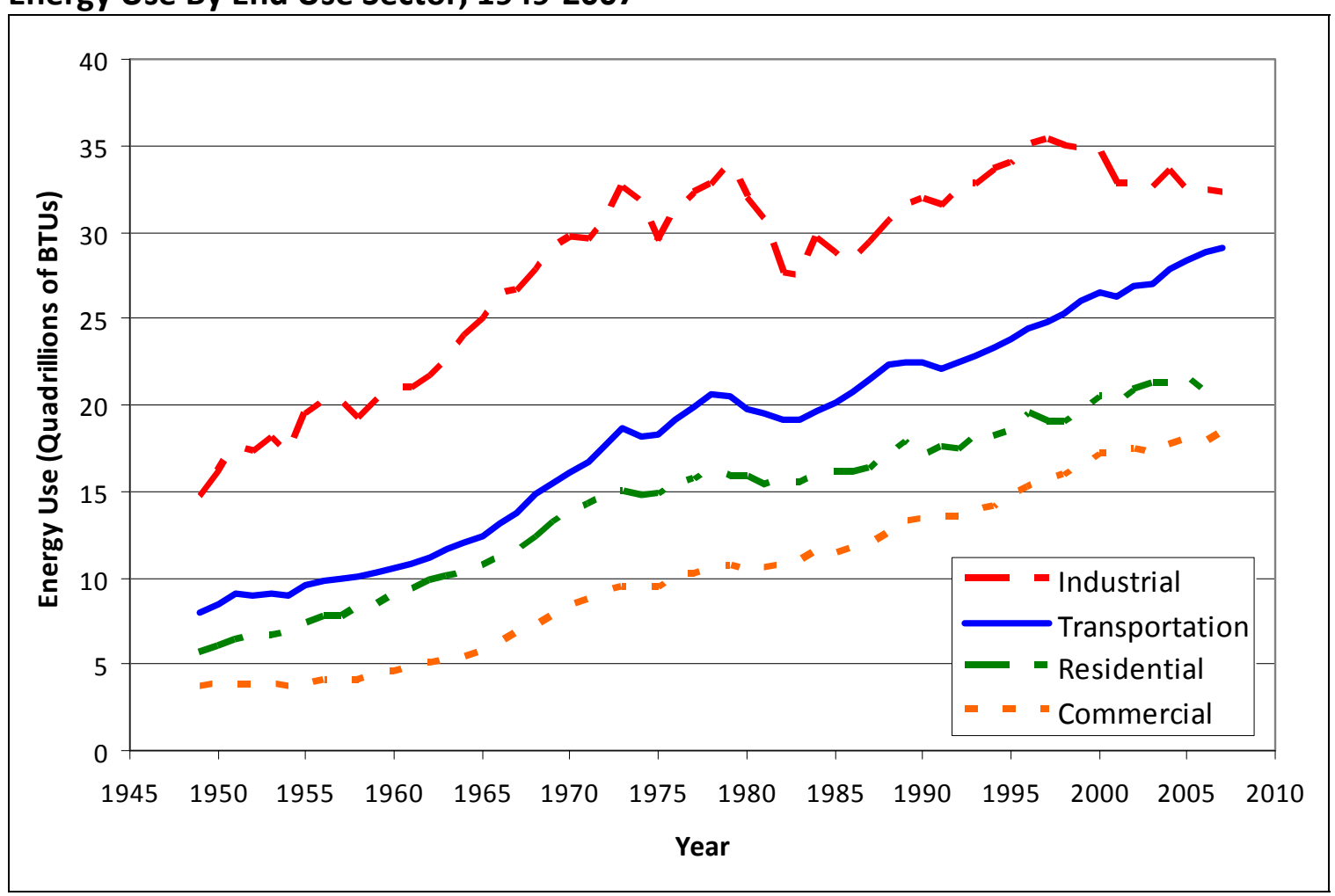

Source: Energy Information Administration (2008), Annual Energy Review, Table 2.1a

The transportation sector was behind only the industrial sector which accounted for 32\% of total energy consumption. While only the second highest consumer in 2007, the 
transportation sector has experienced the highest growth in consumption over the last decade. Since the late-1990's, energy use in the industrial sector has tapered off, peaking in 1997.

Almost all of the energy consumed by the transportation sector is generated from nonrenewable fossil fuels, mainly petroleum products. Since 1995, around $97 \%$ of all energy consumed by the transportation sector was from petroleum (see Table 2.2). Marginal amounts of energy are generated from natural gas, and from electric power plants, which are also mostly fossil-fuel driven. In 2007, only approximately $8.2 \%$ of electric power was generated from 'renewable’ sources (Energy Information Administration, 2008, Annual Energy Review, Table 8.2c).

Table 2.1

Energy Consumption by Transportation Sector by Source (in Quadrillions of BTUs), 1995-2005

\begin{tabular}{|l|r|r|r|r|r|r|}
\hline & $\begin{array}{r}\text { Total } \\
\text { transportation } \\
\text { consumption }\end{array}$ & $\begin{array}{r}\text { Natural } \\
\text { gas }\end{array}$ & Electricity & $\begin{array}{r}\text { Elec. system } \\
\text { energy } \\
\text { losses }\end{array}$ & $\begin{array}{r}\text { Petroleum } \\
\text { products }\end{array}$ & $\begin{array}{r}\text { Petroleum } \\
\text { share of } \\
\text { transportation }\end{array}$ \\
\hline 1995 & 23.96 & 0.72 & 0.02 & 0.04 & 23.18 & $96.7 \%$ \\
\hline 1996 & 24.51 & 0.74 & 0.02 & 0.04 & 23.72 & $96.8 \%$ \\
\hline 1997 & 24.81 & 0.78 & 0.02 & 0.04 & 23.97 & $96.6 \%$ \\
\hline 1998 & 25.36 & 0.67 & 0.02 & 0.04 & 24.64 & $97.2 \%$ \\
\hline 1999 & 26.11 & 0.68 & 0.02 & 0.04 & 25.37 & $97.2 \%$ \\
\hline 2000 & 26.70 & 0.67 & 0.02 & 0.04 & 25.97 & $97.3 \%$ \\
\hline 2001 & 26.27 & 0.66 & 0.02 & 0.04 & 25.56 & $97.3 \%$ \\
\hline 2002 & 26.85 & 0.70 & 0.02 & 0.04 & 26.08 & $97.2 \%$ \\
\hline 2003 & 27.04 & 0.63 & 0.02 & 0.05 & 26.33 & $97.4 \%$ \\
\hline 2004 & 27.92 & 0.61 & 0.02 & 0.05 & 27.23 & $97.5 \%$ \\
\hline 2005 & 28.04 & 0.60 & 0.03 & 0.06 & 27.35 & $97.5 \%$ \\
\hline
\end{tabular}

Note: Electrical system energy losses are incurred in the generation, transmission, and distribution of electricity plus plant use and unaccounted electrical system energy losses.

Source: Bureau of Transportation Statistics (2006), National Transporation Statistics, Table K-1 


\subsubsection{Energy Intensity}

The modes of travel used have a great impact on the amount of energy that is consumed in the transportation sector. The dominance of passenger car travel has led to an inordinate consumption of energy in the transportation sector. This can be demonstrated by taking a look at the energy intensity of different modes, or how much energy is required to move people a given distance.

Highway vehicles, such as passenger cars, trucks, and buses, and aircraft have relatively high energy intensities and rail vehicles have relatively low energy intensities (see Figure 2.2 and Appendix, Tables X2.2-X2.4). Several different factors can impact travel modes’ energy intensity, but two stand out prominently. First, there is the energy required to move a vehicle. In general terms, it is logical to think it would take more energy to move a large vehicle, and less energy to move a smaller vehicle. A second key factor is how many people are traveling in a vehicle. All things being equal, a vehicle carrying many people will have a lower energy intensity than the same vehicle carrying fewer people. 


\section{Figure 2.2}

\section{Energy Intensity by Passenger Mode, 1994-2006}

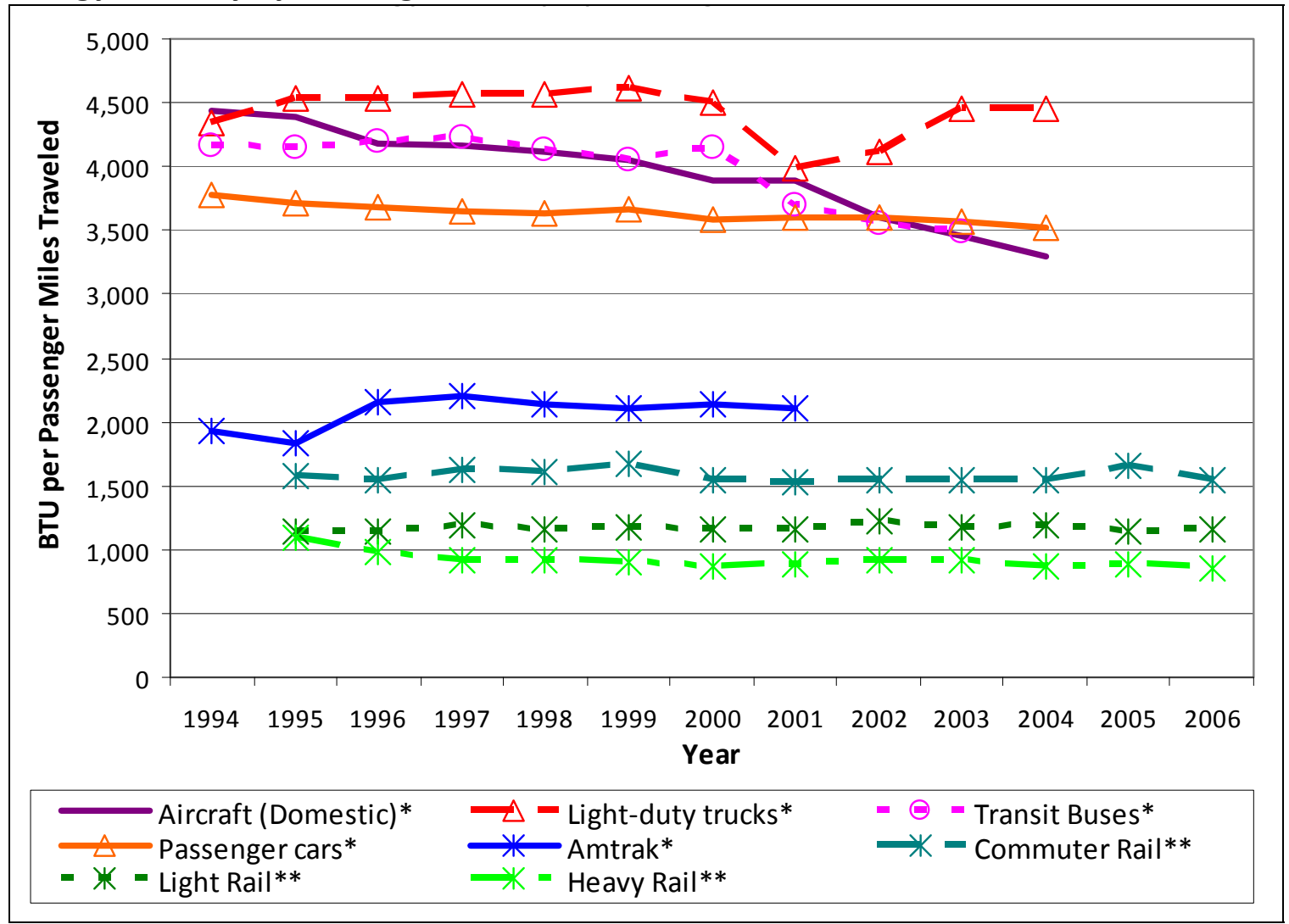

*Source: Bureau of Transportation Statistics (2006), National Transportation Statistics, Table K-6

**Calculation based on passenger and energy consumption figures from the American Public Transportation Association (2007), Public Transportation Fact Book, Tables 6, 27, 2

Evaluation of different modes shows that generally, the mode with the highest energy intensity generally is light-duty trucks. The Bureau of Transportation Statistics defines a light-duty truck as "Trucks of 10,000 pounds gross vehicle weight rating or less, including pickups, vans, truck-based station wagons, and sport utility vehicles.” Logically these vehicles have a higher energy intensity than conventional passenger cars as they are generally larger than passenger cars, but carry similar numbers of passengers.

Rail modes are clearly less energy intensive, with energy intensities approximately half or less of those by highway vehicles. Among the rail modes, heavy rail has the lowest 
energy intensity, followed by light rail, commuter rail, and Amtrak. This relative distribution of these four rail types makes sense in theoretical terms. Generally, heavy rail can hold more passengers than light rail trains, while both theoretically would have higher ridership than commuter rail lines. Heavy and light rail lines are more typically in the more-populated core of a region, with commuter rail serving less-populated, more outlying areas. Amtrak makes sense as the most energy intensive. Amtrak theoretically has similar passenger capacities as the other intra-region types of rail, but travels longer inter-region distances.

Trains are obviously much larger vehicles than passenger cars and trucks, but still have the much lower energy intensities than passenger vehicles. This indicates that the large passenger capacity and corresponding mass of ridership on rail more than makes up for their bigger physical size.

The two wild cards in terms of energy intensity are aircraft and transit buses. In 1994, both modes had higher energy intensities than passenger cars. However, by 2002 both had lower energy intensities than passenger cars.

For buses, ridership or lack there of, has a large impact on the mode's energy intensity. Empty or near-empty buses on poorly utilized routes can have higher energy intensities than cars due to the large physical size of buses. Correlating to the steadily lowering energy intensity for buses from 1994-2003 is an increase in ridership over the period. In 1995, buses logged 18.8 billion passenger miles, and by 2002, this figure had increased to 
21.8 billion passenger miles. Higher ridership does not necessarily mean energy intensity will drop dramatically. For instance, the new ridership could be placed in all new vehicles that consume a lot of energy. However, if a significant portion of the higher ridership can be funneled into existing vehicles, or in essence, the existing fleet is running closer to its capacity, energy intensity can go down. By shear size, a typical bus has many more seats than a typical car, and thus has a great opportunity to run at a higher capacity and lower its energy intensity.

Air travel will not be discussed further in this report, but increases in air travel could have reduced the energy intensity of the mode over this period as well, but this is a trickier comparison due to the nature of air travel. The heaviest consumption of energy for aircraft is on take-off and landing (Aten and Hewings, 1995). Thus, the same distances traveled by many shorter flights would have a greater energy intensity than fewer longer flights. An examination of air travel energy intensities is incomplete without an analysis of the number and length of flights taken.

The inordinate energy use of passenger vehicles, as demonstrated through the mode's high energy intensities, especially compared to rail, raises several issues. However, two primary concerns, environmental and economic, loom especially large considering passenger cars essentially sole-dependence on petroleum products. 


\subsubsection{Carbon Dioxide Generation}

As shown earlier, the transportation sector uses the second most energy out of the four main sectors in an economy. Despite being only the second greatest user, the transportation sector is second to none in terms of the amount of climate altering Carbon Dioxide released into the atmosphere (see Figure 2.3 and Appendix, Table X2.5). In 2006, the transportation sector generated 1.99 billion metric tons of $\mathrm{CO}_{2}$. The industrial sector, the biggest energy user, but second biggest $\mathrm{CO}_{2}$ generator released 1.65 billion metric tons. The rate at which $\mathrm{CO}_{2}$ emissions have grown has also been higher in the transportation sector than in the other three sectors. From 1997 to 2006, emissions in the transportation sector went up 14.1 percent. In the same time frame, emissions in rose in the commercial sector by 13.3 percent, rose in the residential sector by 10.5 percent, and declined in the industrial sector 8.9 percent. 


\section{Figure 2.3}

\section{Carbon Dioxide Emissions by Economic Sector, 1980-2006}

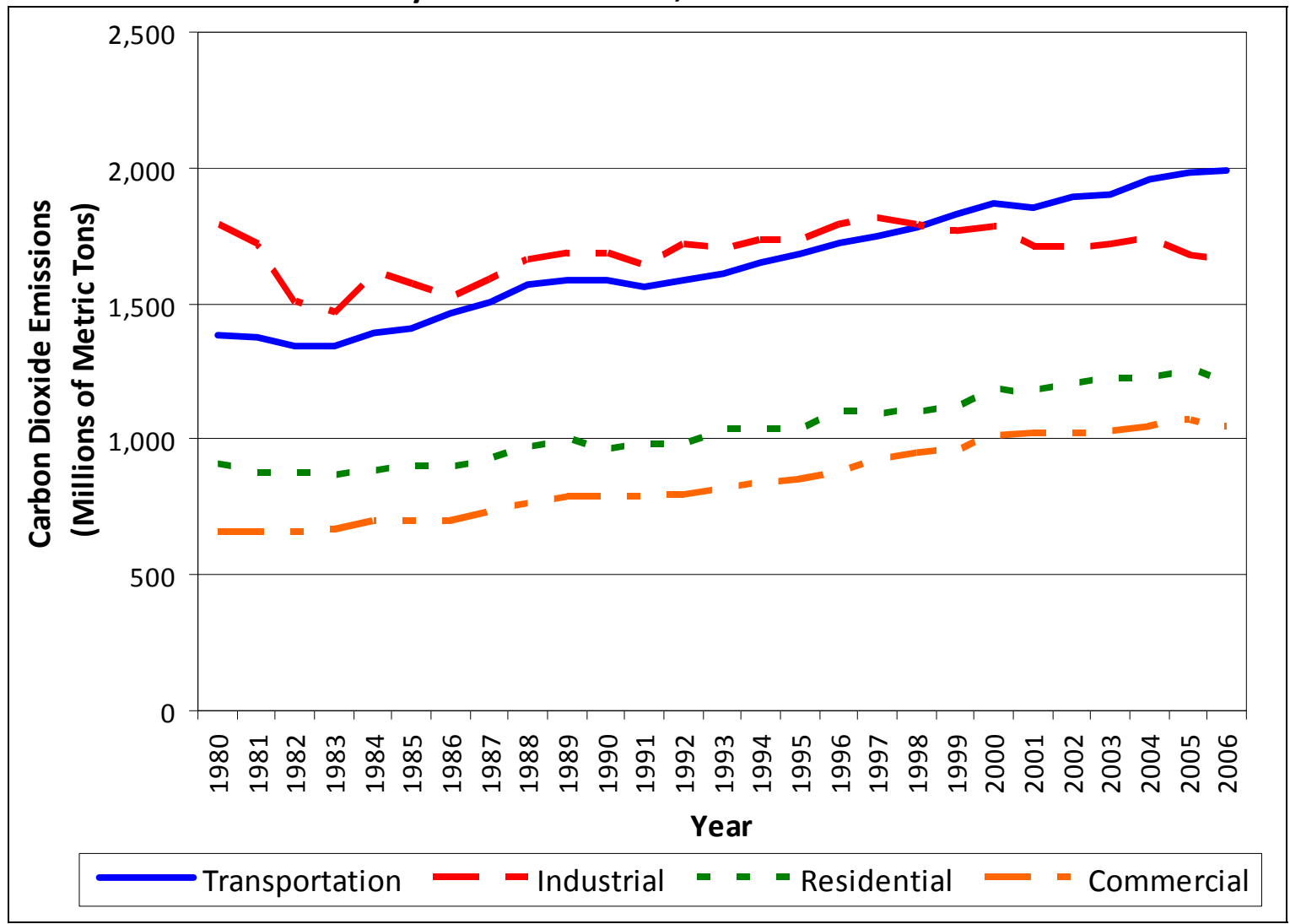

Source: Energy Information Administration (2008), Annual Energy Review, Table 12.2

Within the transportation sector, petroleum use accounts for slightly more than its share of sector's $\mathrm{CO}_{2}$ emissions. As shown previously in Table 2.1, petroleum products accounted for 97.5 percent of transportation sector energy use in 2005. However, the use of petroleum accounted for 98.1 percent of $\mathrm{CO}_{2}$ emissions in 2005 (see Table 2.2).

Table 2.2

Carbon Dioxide Emissions in the Transportation Sector by Energy Source (in Millions of Metric Tons), 2005

\begin{tabular}{|l|r|r|r|}
\hline Petroleum & $\begin{array}{r}\text { Mass of } \\
\text { Emissions }\end{array}$ & $\begin{array}{r}\text { Share of } \\
\text { Emissions }\end{array}$ & $\begin{array}{r}\text { Share of } \\
\text { Energy Use }\end{array}$ \\
\hline Natural Gas & $1,921.7$ & $98.1 \%$ & $97.5 \%$ \\
\hline Electric Power & 31.5 & $1.6 \%$ & $2.1 \%$ \\
\hline Total & 5.4 & $0.3 \%$ & $0.3 \%$ \\
\hline
\end{tabular}

Source: Energy Information Administration (2006), Annual Energy Review, Table 12.3; Bureau of Transportation Statistics (2006), National Transportation Statistics, Table K-1 
Natural gas, which accounted for $2.1 \%$ of energy use in 2005, was only responsible for $1.6 \%$ of $\mathrm{CO}_{2}$ emissions. $95.3 \%$ of transportation sector natural gas consumption in 2005 was by buses. Electric power accounted for .3\% of energy use and .3\% of $\mathrm{CO}_{2}$ emissions. 98.9\% of transportation sector electric power consumption in 2005 was by mass transit, almost entirely by rail with some trolley bus use.

Petroleum accounts for a disproportionate share of carbon emissions because compared to other fuels it has relatively high carbon content, taking into account both the carbon content in a given quantity of fuel, and the energy that quantity generates. The two main petroleum based fuels used in transportation, gasoline and petro-diesel, contain approximately 20 grams of carbon for each megajoule of energy produced (see Table 2.3 and Appendix Table X2.6). This is approximately 40\% greater than the carbon content of natural gas.

\section{Table 2.3}

Relative carbon content of different energy fuels (grams of carbon per megajoule of energy produced)

\begin{tabular}{|l|r|}
\hline & Carbon content per unit energy \\
\hline Coal & $25.4 \mathrm{~g} / \mathrm{mJ}$ \\
\hline Gasoline & $19.9 \mathrm{~g} / \mathrm{mJ}$ \\
\hline Petro-Diesel & $20.1 \mathrm{~g} / \mathrm{mJ}$ \\
\hline Natural Gas & $14.2 \mathrm{~g} / \mathrm{mJ}$ \\
\hline
\end{tabular}

Source: Oak Ridge National Laboratory, Bioenergy Conversion Factors

The only major fuel used in any economic sector that has higher carbon content than petroleum is coal. While not used directly in transportation, it is a fuel used to generate some electric power used in transportation. Nearly two thirds, 62.9\%, of United States electricity production in 2005 was fueled by high carbon coal and petroleum. However, 
$22.5 \%$ was fueled by lower carbon natural gas, as well as $11.4 \%$ from zero carbon emission nuclear, hydroelectric, geothermal, solar, and wind sources (see Table 2.4). As a result of these lower carbon and zero carbon sources, electric power use in transportation did not lead to a disproportionately large amount of $\mathrm{CO}_{2}$ emissions. There was not enough of these sources however to lead to a disproportionately small amount of $\mathrm{CO}_{2}$ emissions either.

Table 2.4

Share of fuels used in electric power generation

\begin{tabular}{|l|r|l|r|}
\hline Fuel & Share & Fuel & Share \\
\hline Petroleum & $40.2 \%$ & Geothermal & $0.3 \%$ \\
\hline Coal & $22.7 \%$ & Wind & $0.2 \%$ \\
\hline Natural Gas & $22.5 \%$ & Solar & $0.1 \%$ \\
\hline Nuclear & $8.1 \%$ & Biomass & $3.1 \%$ \\
\hline Hydroelectric & $2.7 \%$ & Imports & $0.1 \%$ \\
\hline
\end{tabular}

Source: Energy Information Administration (2008), Annual Energy Review, Table 1.3

\subsubsection{Energy Prices}

The inordinate consumption of energy derived from petroleum products is troublesome economically as oil prices have been relatively high in recent years compared with the last century of automobile travel. In 2008, gas prices reached $\$ 3.26$ per gallon on average, a high, adjusted for inflation, only scene twice before, during the 1979 Energy Crisis, and back in the early 1920s when automobile travel was in its infancy (Energy Information Administration, Short-Term Energy Outlook, 2009). While in 2009, prices have dropped sharply from the 2008 peak, gas prices can generally be described as more expensive than more than half of the preceding 90 years. Projections for 2010 by the Energy Information Administration foresee an uptick again in gas prices, although not to the level seen in 2008 (see Figure 2.4 and Appendix, Table X2.7). 


\section{Figure 2.4}

Real Gasoline Pump Prices: Annual Average, 1919-2010 (in 2008 Dollars)

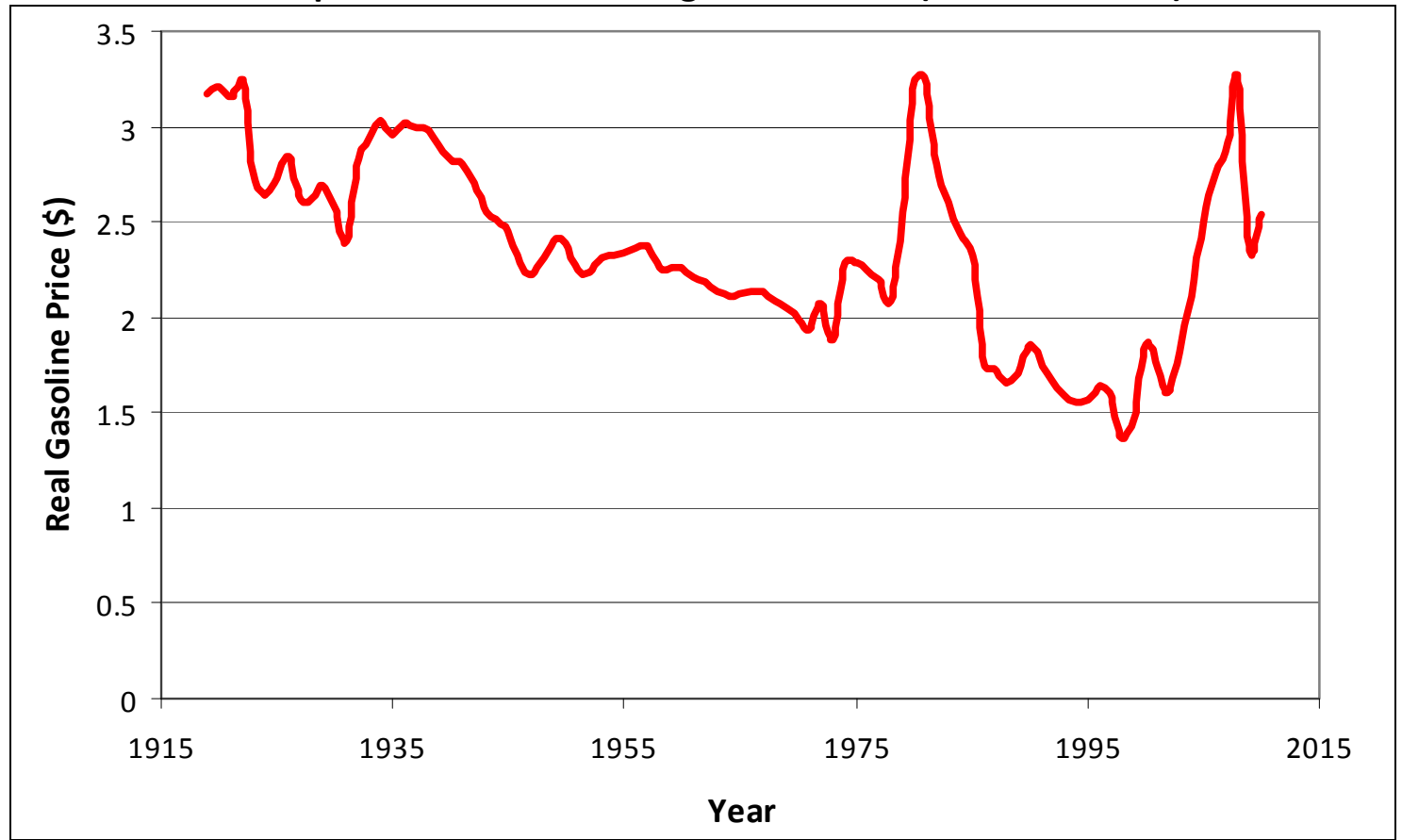

*Projection for 2010

Source: Energy Information Administration (2009), Short-Term Energy Outlook, Real Petroleum Prices

High gas prices can have repercussions on the economy as a whole. It is reasonable to expect that automobile vehicle miles traveled would go down if gasoline becomes extremely expensive. In 2008, as gas prices rose sharply, automobile vehicle miles traveled dropped sharply (see Figure 2.5 and Appendix, Table X2.8). This is an unprecedented decline, as generally vehicle miles travel increase annually, this being the first decline since 1980 .

A decrease in vehicle miles traveled has some benefits, as less traveling, means less energy consumption, and thus less pollution. High fuel prices are associated with increases in public transit ridership as well. 
It can not be definitively said that high gas prices alone have led to a decrease in vehicle miles traveled, since as gas prices have dropped from their 2008 peak, VMT has not rebounded in kind. However, if it is at least a contributor to decreasing vehicle miles travel, part of the decline can be linked to a decrease in economic activity. Typically, people do not make trips for the sake of making trips, they do it for a purpose which often has an economic component, whether earning or spending money. If economic activity goes down, vehicle miles traveled goes down, economic activity goes down, unless the same types of trips are made only to shorter distances, or are taken on other modes. This has consequences on segments of the economy, and areas of the country, reliant on automobile travel.

Figure 2.5

Gas Prices and Vehicle Miles Traveled, January 2007-June 2008

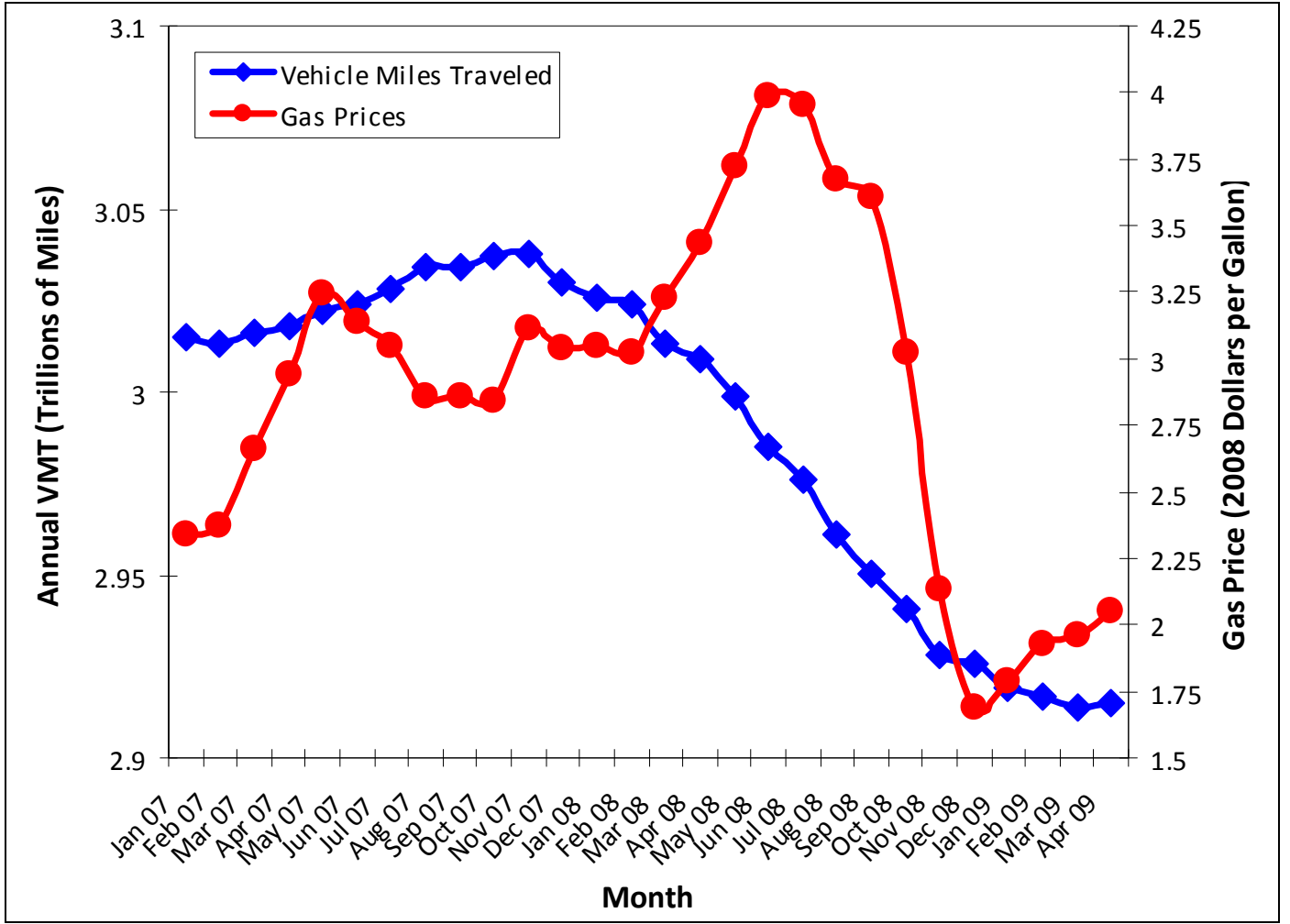

Source: Energy Information Administration (2009), Short-Term Energy Outlook, Real Petroleum Prices; Federal Highway Administration (2009), Traffic Volume Trends, Figure 1 


\subsection{Other Economic Costs}

Burchell and Mukherji (2003) examine the relative costs of future development built under two physical layout scenarios, an auto conducive Conventional Development scenario, and a more transit favorable Managed Growth Scenario. At the base of their model are projections of needed residential and non-residential development between 2000 and 2025. In both scenarios, the space needs are accommodated completely. Comparing costs in their model results finds significant potential savings if development followed the physical layout of the Managed Growth scenario.

The Conventional Development scenario assumes that current development trends of sprawl are extended into the future. Typical sprawl development is described to be low density, mainly single-family subdivisions and strip commercial. In this scenario, growth is geographically unconstrained. If the existing physical layout of development is continued, so too likely would be the automobile dominated transportation system that serves it.

The key of the Managed Growth scenario is that growth is geographically constrained, with development clustered adjacent to already built-up areas, and thus also within easier access to existing public services and infrastructure. This scenario would also have denser development. Additional transit-oriented development would fit under the Managed Growth scenario due to its greater density and location closer to urbanized areas, where transit services are more likely to exist and be more effective. 
To get water and sewer service, individual developments need to be attached, via lateral connections, to water and sewer systems. Generally, single family detached units require more lateral connections than the same number of multi-family or single-family attached units. Burchell and Mukherji modeled that in the Conventional Development scenario, almost 46 million laterals would be required to service new growth to 2025. However, in the Managed Growth Scenario, only slightly more than 41 million laterals are required. The elimination of those extra laterals could decrease the cost of water infrastructure by 12.6 billion dollars, a savings of 6.6\% (see Table 2.5 ).

Table 2.5

Projected Water and Sewer Infrastructure under Conventional Development and Managed Growth Scenarios, 2000-2025

\begin{tabular}{|l|c|c|c|c|}
\hline & $\begin{array}{c}\text { Conventional } \\
\text { Development }\end{array}$ & $\begin{array}{c}\text { Managed } \\
\text { Growth }\end{array}$ & Savings & $\begin{array}{c}\text { Percent } \\
\text { Savings }\end{array}$ \\
\hline Total Water and Sewer Lateral (Thousands) & 45,867 & 41,245 & 4,621 & $10.1 \%$ \\
\hline Total Infrastructure Costs (Billions) & $\$ 189.8$ & $\$ 177.2$ & $\$ 12.6$ & $6.6 \%$ \\
\hline
\end{tabular}

Source: Burchell and Mukherji (2003), Compact Development Versus Managed Growth: The Costs of Sprawl, Table 3

The Managed Growth scenario also shows savings over the Conventional Development scenario in terms of road building costs. The extra area of the Conventional Development scenario requires an additional 188,305 lane-miles of roadway be built compared to the Managed Growth scenario. These additional lane-miles make the Managed Growth scenario 109.7 billion dollars cheaper, a savings of almost 12 percent (see Table 2.4). The authors note that even though the Managed Growth scenario requires less road building, a considerable amount of road building is still required. In developed areas, growth may necessitate some new roadways, but also widening of current roadways adding new lane- 
miles. One caveat to this monetary savings calculation is that it does not include land acquisition costs for rights of way.

\section{Table 2.6}

Projected Local Road Infrastructure under Conventional Development and Managed Growth Scenarios, 2000-2025

\begin{tabular}{|l|c|c|c|c|}
\hline & $\begin{array}{c}\text { Conventional } \\
\text { Development }\end{array}$ & $\begin{array}{c}\text { Managed } \\
\text { Growth }\end{array}$ & Savings & $\begin{array}{c}\text { Percent } \\
\text { Savings }\end{array}$ \\
\hline Total Lane-Miles Required & $2,044,179$ & $1,855,874$ & 188,305 & $9.21 \%$ \\
\hline Total Infrastructure Costs (Billions) & $\$ 927.0$ & $\$ 817.3$ & 109.7 & $11.83 \%$ \\
\hline
\end{tabular}

Source: Burchell and Mukherji (2003), Compact Development Versus Managed Growth: The Costs of Sprawl, Table 4

Beyond infrastructure costs, new development must be served by local government public services, which have a fiscal impact on the jurisdictions that are home to the new development. Typically, new development does not pay for all its needed public services itself, and Burchell and Mukherji find deficits under both scenarios. However, in the Managed Growth scenario, the deficit is smaller than in the Conventional Development scenario. This is driven by economies of scale which exist when more development is grouped together. Further, when growth is placed closer to existing development, some public service needs could be absorbed by excess capacity in existing developments as opposed to requiring entirely new public services.

In both scenarios, Burchell and Mukherji project similar incoming revenues to local governments of over 99 billion dollars. Recall that both scenarios are completely accommodating all growth needs to 2025. However, the Managed Growth scenario incurs costs of 139.2 billion dollars compared to 143.2 billion dollars for the Conventional 
Development scenario. Again, while both sustain deficits, in the Managed Growth scenario the deficit is 4.2 billion dollars smaller, 9.6 percent less (see Table 2.7).

Table 2.7

Projected Fiscal Impact Under Conventional Development and Managed Growth Scenarios, 2000-2025

\begin{tabular}{|l|r|r|}
\hline Fiscal Impact (Billions) & $\begin{array}{r}\text { Conventional } \\
\text { Development }\end{array}$ & $\begin{array}{r}\text { Managed } \\
\text { Growth }\end{array}$ \\
\hline Costs & $\$ 143.2$ & $\$ 139.2$ \\
\hline Revenues & $\$ 99.4$ & $\$ 99.5$ \\
\hline Deficit & $\$-43.8$ & $\$-39.6$ \\
\hline \multicolumn{2}{|c|}{ Difference (Conventional Minus Managed) } & $\$ 4.2$ \\
\hline \multicolumn{2}{|c|}{ Percent Difference } & $9.6 \%$ \\
\hline
\end{tabular}

Source: Burchell and Mukherji (2003), Compact Development Versus Managed Growth: The Costs of Sprawl, Table 5

\subsection{Preference for Alternative Development}

\subsubsection{Boston and Atlanta Case Study}

Levine, Inam, and Torng (2005) looked at people’s responsiveness to alternative types of land use. In their study they discovered a significant proportion of their survey respondents were supportive of living in pedestrian and transit-oriented neighborhoods. They also found that there was a discrepancy between what people desired in their neighborhoods, and where they actually lived, illustrating an unmet demand for alternatively designed neighborhoods.

For their study, 800 households were selected in both Boston and Atlanta. These two cities were selected because of their differences in layout. As a result of when they were historically developed, Boston has a relatively wider array of neighborhood types, from 
auto-oriented to pedestrian and transit-oriented. Atlanta, on the other hand, has developed dominantly auto-oriented. Respondents in both cities were asked a series of trade-off questions to determine whether they preferred the attributes, and the associated benefits and costs, of living in more auto-oriented neighborhoods, or of living in more pedestrian and transit-oriented neighborhoods.

In Boston, a plurality of respondents preferred pedestrian-oriented neighborhoods, and in Atlanta, a plurality of respondents preferred auto-oriented neighborhoods (see Table 2.8). At first glance, this makes sense considering the general land use characteristics of the two metropolitan areas. However, the results become surprising when looking specifically at the types of neighborhoods the respondents actually lived in.

\section{Table 2.8}

Neighborhood preference factors, Boston and Atlanta

\begin{tabular}{|c|c|c|c|c|c|}
\hline & $\begin{array}{c}\text { Very Strong } \\
\text { Pedestrian } \\
\text { Neighborhood } \\
\text { Preference }\end{array}$ & $\begin{array}{c}\text { Pedestrian } \\
\text { Neighborhood } \\
\text { Preference }\end{array}$ & $\begin{array}{c}\text { Mean } \\
\text { (Neutral) } \\
\text { Preference }\end{array}$ & $\begin{array}{c}\text { Auto } \\
\text { Neighborhood } \\
\text { Preference }\end{array}$ & $\begin{array}{c}\text { Very Strong } \\
\text { Auto } \\
\text { Neighborhood } \\
\text { Preference }\end{array}$ \\
\hline Boston & $4.5 \%$ & $35.5 \%$ & $31.2 \%$ & $24.3 \%$ & $4.5 \%$ \\
\hline Atlanta & $6.4 \%$ & $23.0 \%$ & $29.7 \%$ & $34.2 \%$ & $6.7 \%$ \\
\hline
\end{tabular}

Source: Levine, Inam, and Torng (2005), Table 3

Levine, Inam, and Torng broke down their respondents as living in neighborhoods that fell into five different land-use clusters (see Table 2.9). Three land-use clusters, central business district, other central city, and inner suburban, were marked as more pedestrian/transit-oriented areas. 
The other two land-use clusters, middle suburban and outer suburban/exurban were marked as more auto-oriented areas.

\section{Table 2.9}

Where respondents lived (by neighborhood cluster), Boston and Atlanta

\begin{tabular}{|c|c|c|c|c|c|}
\hline & $\begin{array}{c}\text { Central } \\
\text { Business } \\
\text { District (A) }\end{array}$ & $\begin{array}{c}\text { Other Central } \\
\text { City (B) }\end{array}$ & $\begin{array}{c}\text { Inner } \\
\text { Suburban (C) }\end{array}$ & $\begin{array}{c}\text { Middle } \\
\text { Suburban (D) }\end{array}$ & $\begin{array}{c}\text { Outer } \\
\text { Suburban/ } \\
\text { Exurban (E) }\end{array}$ \\
\hline Boston & $2.6 \%$ & $17.3 \%$ & $34.6 \%$ & $33.2 \%$ & $12.4 \%$ \\
\hline Atlanta & $0.5 \%$ & $2.9 \%$ & $8.4 \%$ & $27.9 \%$ & $60.3 \%$ \\
\hline
\end{tabular}

Source: Levine, Inam, and Torng (2005), Table 1

In Atlanta, $88.2 \%$ of respondents lived in the auto-oriented land clusters, but as shown, only $40.9 \%$ of respondents signaled an auto-oriented preference. If auto travel was dominant because people wholeheartedly wanted to drive a lot, one would expect Atlantans to live in auto-oriented neighborhoods and really want to be there too. Also in Atlanta, 29.4\% of respondents signaled some preference for pedestrian-oriented neighborhoods. However, only $11.8 \%$ of Atlantans lived in the more pedestrian friendly land use clusters. This indicates that in Atlanta, those preferring a more pedestrianoriented neighborhood were constrained by something when trying to act on those preferences.

Just like in Atlanta, in Boston there are more people living in the auto-oriented clusters than prefer them. $28.8 \%$ of Bostonians signaled an auto-oriented preference, but a much large share, $45.6 \%$ of the regions residents, lived in the two more auto-oriented land use clusters. This was despite Boston’s lower preference for auto-oriented neighborhoods than Atlanta. 
Boston differed in that there were people who both preferred pedestrian-oriented neighborhoods and resided in more pedestrian friendly land use clusters. $40.0 \%$ of Bostonians signaled a preference for pedestrian-oriented neighborhoods, and a larger share, $54.5 \%$ lived in the three more pedestrian friendly clusters. However, this figure is less than $71.2 \%$, the total of pedestrian preferring plus the neutral respondents..

Overall, residents in Boston and Atlanta live in regions with significantly different physical form. Atlantans live in almost entirely auto-oriented areas, while Bostonians live in a region that is only slightly auto-oriented, with much more balance toward pedestrian and transit-oriented areas. The two areas also had differing preferences, but not radically different. The differences were only a slight plurality one way or the other. In discussing this circumstance, and modeling for additional factors, Levine, Inam, and Torng conclude that "the differences in preferences are insufficient to explain differences in outcomes."

Levine, Inam, and Torng also discuss that much of the current policy discussion and debate on the physical form of cities are based upon "An implicit worldview that current auto-dependent development are a product of individual preferences revealing themselves through markets” (Levine, Inam, and Torng, p. 13). However, if the layout of land use in cities was truly all about preferences, perhaps Atlanta would look more like Boston. Levine, Inam, and Torng suggest that if Atlantans "had a set of choices available that was less constrained into a low-density, automobile-oriented development form, they might well opt for such choices, and such a move would bring their preferences and their choices closer together” (Levine, Inam, and Torng, p. 13). 


\subsubsection{Preferences in the Bay Area}

The San Francisco Bay Area Metropolitan Transportation Commission’s Transportation 2035 Poll included a pair of questions on land use preferences (Metropolitan

Transportation Commission, 2007). The MTC poll questions were similar to those posed by Levine, Inam, and Torng as they were phrased in terms of trade-offs. The results of the poll questions showed a clear openness towards alternative land use.

\section{Exhibit 2.1}

\section{Tradeoffs in housing choice, Bay Area Transportation 2035 Poll}

Question: Many people say they face tradeoffs when choosing a place to live - meaning that they have to give up some things in order to have other things. How do you feel about the following tradeoffs? Other things being equal:

- Would you choose to live in a small home with small backyard, if it means you have a short commute to work (A), or

- Would you choose to live in a large home with a large backyard, even if it means you would have a long commute to work (B)?

\begin{tabular}{|c|c|c|c|c|}
\hline Option A & Option B & Both & Neither & Don't Know/NA \\
\hline $74 \%$ & $19 \%$ & $1 \%$ & $3 \%$ & $4 \%$ \\
\hline
\end{tabular}

By nearly a 4 to 1 margin, respondents preferred Option A. While this question was mode of travel neutral, the denser layout of Option A would be relatively more pedestrian friendly, and easier to provide transit into. The less dense Option B would be more difficult to implement pedestrian friendliness and transit service, and would become increasingly auto dependent the less dense, and the larger homes became.

\section{Exhibit 2.2}

Tradeoffs in density versus open space/air quality, Bay Area Transportation 2035 Poll Question: Thinking again about tradeoffs, would you be willing to accept an increase in the number of homes and the amount of traffic in your community, if it protected open space and the quality of air in the Bay Area?

\begin{tabular}{|c|l|}
\hline $67 \%$ & Yes, willing to accept more homes \& traffic for open space \& air quality \\
\hline $28 \%$ & No, not willing to accept more homes \& traffic for open space \& air quality \\
\hline $1 \%$ & None of the Above \\
\hline $4 \%$ & Don't Know/NA \\
\hline
\end{tabular}


Again, while not looking into modes, the results of this question imply openness to additional density, at least in a general sense. Adding density is a trickier political operation when discussing real projects in actual neighborhoods, but the results at least belay a supportive starting point.

\subsection{Economic Benefits of TOD}

The economics of transportation are important to everyday commuters as transportation costs are the second largest expense for typical households. The Bureau of Labor Statistics Consumer Expenditure Survey found that the average consumer unit spent $\$ 8,508$ in transportation expenses in 2006 . This was $17.6 \%$ of all spending. Only housing drew more expenditure. Transportation was thus more costly than other necessities like food, health care, and clothing (see Table 2.10).

Table 2.10

Average Annual Consumer Expenditures (Dollars), 2006

\begin{tabular}{|l|r|r|}
\hline & Cost (\$) & Percent \\
\hline Housing & 16,366 & $33.8 \%$ \\
\hline Transportation & 8,508 & $17.6 \%$ \\
\hline Personal Insurance/Pensions & 6,111 & $12.6 \%$ \\
\hline Health and Personal Care & 5,270 & $10.9 \%$ \\
\hline Entertainment/Reading & 3,351 & $6.9 \%$ \\
\hline Apparel & 2,493 & $5.2 \%$ \\
\hline Cash Contributions & 1,874 & $3.9 \%$ \\
\hline Education & 1,869 & $3.9 \%$ \\
\hline Miscellaneous & 888 & $1.8 \%$ \\
\hline Alcohol and Tobacco & 846 & $1.7 \%$ \\
\hline Total & 824 & $1.7 \%$ \\
\hline
\end{tabular}

Source: Bureau of Labor Statistics (2007), Consumer Expenditure Survey, Table 7 
A consumer unit, the unit of analysis used in the Consumer Expenditure Survey, is essentially the Bureau of Labor Statistics equivalent of a household. The average consumer unit was made up of 2.5 persons, with 0.6 persons younger than 18 , and 0.3 persons 65 years or older. They were supported by an average of 1.3 wage earners, and operated 1.9 vehicles.

Spending on transportation varied by where consumer units live in regions. Residents of central cities spent the least on transportation. Residents of urbanized areas outside central cities had significantly higher transportation costs. Rural residents generally spent less on transportation than urban residents as a whole, however they spent over one thousand dollars more than central city residents. (see Table 2.11).

Transportation expenditures were broken down in the Consumer Expenditure Survey into four types of costs. Three of the costs were related to the owning and operating of a motor vehicle, the payment for the vehicle itself, gasoline and motor oil costs, and the numerous other vehicle costs, which included necessities like maintenance and insurance. Central city residents had the lowest expenditures in all three of these vehicle costs by a significant margin. 
Table 2.11

Average Annual Transportation Expenditures by Type of Area (Dollars), 2006

\begin{tabular}{|l|r|r|r|r|r|}
\hline & \multirow{2}{*}{ Overall } & \multicolumn{3}{|c|}{ Urban } & \multirow{2}{*}{ Rural } \\
\cline { 3 - 5 } & & Total & Central City & Other Urban & \\
\hline Total Transportation & 8,508 & 8,547 & 7,024 & 9,293 & 8,091 \\
\hline Vehicle purchase & 3,421 & 3,438 & 2,736 & 3,782 & 3,236 \\
\hline Gasoline and Oil & 2,227 & 2,188 & 1,756 & 2,400 & 2,652 \\
\hline All Other Vehicle Costs & 2,355 & 2,386 & 1,978 & 2,587 & 2,015 \\
\hline Public transport & 505 & 534 & 554 & 524 & 188 \\
\hline
\end{tabular}

Source: Bureau of Labor Statistics (2007), Consumer Expenditure Survey, Table 7

Central city residents did have the highest public transportation costs. However, the difference is slight compared to other urban residents. Rural residents had far lower public transportation costs, not surprising due to the dearth of public transit in rural areas.

Generally in central cities, there will be greater access to transit. Also, there are generally more barriers to driving with issues of parking availability, parking cost, and congestion. As a result, it would make sense that central city residents drive less. The Consumer Expenditure Survey does not break down transportation costs data by what commuter's primary mode of travel is. However, the data that is provided does infer that central city residents drive less.

The lower vehicle purchase costs indicate that central city residents are likely buying fewer cars. One piece of data the Consumer Expenditure Survey does provide is that central city residents have the highest rate, $22 \%$, of consumer units who do not own at least one vehicle. However, the vast majority of consumer units, 78\%, do own at least one vehicle. Overall, $87 \%$ of urban residents own at least one vehicle, with $92 \%$ of other non-central city urban residents owning at least one vehicle (see Table 2.12). 
Table 2.12

Percent of Consumer Units That Own At Least 1 Vehicle, 2006

\begin{tabular}{|c|c|}
\hline Consumer Units* & $\begin{array}{c}\text { Percent Owning } \\
\text { Vehicle }\end{array}$ \\
\hline All Consumer Units & $\mathbf{8 8 \%}$ \\
\hline Urban - Total & $\mathbf{8 7 \%}$ \\
\hline Urban - Central City & $78 \%$ \\
\hline Urban - Other & $92 \%$ \\
\hline Rural & $\mathbf{9 3 \%}$ \\
\hline
\end{tabular}

*Consumer units are defined as: (1) All members of a particular household who are related by blood, marriage, adoption, or other legal arrangements; (2) a person living alone or sharing a household with others or living as a roomer in a private home or lodging house or in permanent living quarters in a hotel or motel, but who is financially independent; or (3) two or more persons living together who use their incomes to make joint expenditure decisions.

Source: Bureau of Labor Statistics (2007), Consumer Expenditure Survey, Table 7

Whether living in central cities, or other urban areas, or rural areas, people still need to make trips. So if central city residents do not drive as much, presumably these trips are made up in other modes, like public transit. However, these trips substituted in other modes appear to not carry a proportionate level of cost. Central city residents are saving much more on private vehicle costs than the additional expenditure on public transit. On average, central city residents spend nearly 2300 dollars less in private vehicle costs, but pay only 30 dollars more in transit costs (see Table 2.13). Due to the density of central cities, car trips may also be significantly substituted with pedestrian and bicycle trips, which generally have even lower costs than public transit.

Table 2.13

Private Vehicle vs. Public Transport Costs in Central Cities and Other Urban Areas

\begin{tabular}{|l|c|c|c|}
\hline & Central City & Other Urban & $\begin{array}{c}\text { Central city versus } \\
\text { Other Urban }\end{array}$ \\
\hline Private Vehicle costs (\$) & 6,470 & 8,769 & 2,299 less \\
\hline Public transport costs (\$) & 554 & 524 & 30 more \\
\hline
\end{tabular}

Source: Bureau of Labor Statistics (2007), Consumer Expenditure Survey, Table 7 
An important thing to keep in mind about the Consumer Expenditure Survey data is that it is providing average data on transportation costs. It does not calculate what a primarily car commuter spends versus what a public transit commuter spends.

A theoretical comparison between costs of different modes is offered by the American Public Transportation Association (APTA). Their September 2008 “Transit Savings Report” estimated that an average commuter in an urban area could save $\$ 9,596$ per year by commuting via transit over automobile. Specifically for the San Francisco Bay Area, they estimate a commuter could save even more, $\$ 12,648$ per year, or $\$ 1,054$ per month, by using transit (APTA, 2008).

While this calculation was carried out by a trade group representing transit agencies pursuing transit advocacy, they are transparent on their methodology. Costs of commuting by transit are based on average monthly pass fare information gathered by their member agencies. They assume a commuter switching to transit as their primary commute mode would seek to use a monthly pass when available over paying base fares daily.

Vehicle costs are based on a cost of driving formula by the American Automobile Association (AAA). This formula is based on variable costs, such as gas and maintenance, and fixed costs, such as registration and insurance. In this way, their vehicle cost estimation is much like the Bureau of Labor Statistics calculation. AAA assumes commuters are driving an average mid-size vehicle, with a fuel economy of 23.4 miles 
per gallon. They also assume yearly driving of 15,000 miles. Vehicle commuting costs also include parking costs as found in the 2008 Colliers International Parking Rate Study. That study showed that parking alone in a downtown business district was $\$ 134$ per month (APTA, 2008).

The methodology used appears reasonable. However, since they are making several assumptions, savings for individual drivers will vary. Commuters with a less fuel efficient car and longer commutes will save more than the same commuter with a more fuel efficient car and a shorter commute. Parking will cause significant variation in actual savings versus average savings as a commuter who works in an expensive to park downtown area will save much more than someone whose workplace offers free parking. A particularly high point of the methodology is that it does not assume transit commuters do not drive at all. The estimate assumes primarily transit commuters own one less car.

The BTS data and APTA comparisons reveal that significant savings may accrue to residents who live in communities with similar characteristics as central cities, and to commuters who have good availability to public transit. Transit-oriented developments, which are compact, higher-density, mixed-use, and have access to transit, share these characteristics with central cities. Thus, transit-oriented developments can be expected to give their residents savings in transportation costs. 


\subsection{Characteristics of Successful TOD}

People's preferences for transit and pedestrian-oriented lifestyles, the benefits of transitoriented development, and costs of conventional development will not necessarily get people to move into a transit-oriented development. When individuals make housing decisions, they are not in a vacuum of travel mode alone. People are looking for things like amenities, services, and character. Robert Cervero concludes that "An important challenge in creating successful transit-oriented environments, then, is to plan, design, and build compact yet attractive communities that are well served by alternative modes such as transit and that are also affordable, have good schools, are safe to be in, and, in short, are like traditional suburbs in most other ways” (Cervero, 1999).

So, what then are the keys of creating successful and livable transit-oriented developments? The New Transit Town: Best Cases in Transit-Oriented Development contains a series of essays on basics of transit-oriented development and case studies from around the United States. A key distinction that the book attempts to lay out is how to create transit-oriented development that integrates communities with transit well versus transit-adjacent development that is merely next to transit. One essay in the book by Dittmar and Poticha (2004) states several central goals for developments that would make them truly transit-oriented. 


\subsubsection{Location Efficiency}

Dittmar and Poticha first state that transit-oriented developments should exhibit location efficiency. This involves the conscious placement of housing near transit such that transit systems are well utilized and residents can use transit effectively. Location efficiency is dependent upon three components, density, transit accessibility, and pedestrian friendliness.

Density is important as in order for transit service to be sustained, there must be sufficient densities to support it. Dittmar and Poticha point out studies by Zupan and Pushkarev, 1977, Frank and Pivo, 1994, and Messenger and Ewing, 1996. Zupan and Pushkarev found that transit use was related to, and automobile use was inversely related to, residential density and non-residential agglomerations around transit stops. Frank and Pivo, 1994 supported their results. Messenger and Ewing, 1996 looked at minimums for bus service and concluded eight units per acre or greater are required to sustain 25-minute headways, and 11 units per acre or greater are required to sustain 15-minute bus service frequencies (Dittmar and Poticha, 2004).

Transit accessibility is a straightforward component to location efficiency. Transit stations and stops should be convenient so people can easily use transit service. The third component of location efficiency, pedestrian friendliness, can enhance this by connecting transit stops and other uses throughout a transit-oriented district. Furthermore, Dittmar and Poticha cite a study by Holtzclaw et al., 2002, that showed housing density, transit service, and pedestrian and bicycle friendliness were together the three key variables that 
best predicted auto use and household transportation expenditures once household size and income were controlled for.

\subsubsection{Rich Mix of Choices}

Another central goal Dittmar and Poticha state is that transit-oriented developments should provide a rich mix of choices. There should be a rich mix of housing types, from compact single-family, to apartments, to condominiums, to live-work units. Having this variety can create a diverse community in terms of age, family type, household size, and income among others, as people in different life situations and stages may desire different types of housing. Dittmar and Poticha point out that having different choices in the same transit-oriented neighborhood could allow the same person to fill different slots of this diversity at different times. An individual could start in one type of housing at one point in life, move to different types at other points in life, and not be forced to leave the community.

The focus on providing choices serves as a reminder that transit-oriented development is not about forcing people to live a certain way. In a separate essay in The New Transit Town, Dittmar, Belzer, and Autler, point out, “Transit-oriented development has been touted as a panacea, with some arguing that all metropolitan growth can be accommodated through higher density infill development along transit lines - a physical possibility perhaps, but not viable in a democracy” (Dittmar, Belzer, and Autler, 2004). Instead, Dittmar, Belzer, and Autler argue that transit-oriented development provides a choice for households. Certainly as discussed, transit-oriented is an underutilized and 
beneficial choice, but still a choice. Providing a rich mix of housing choices however can make transit-oriented development more things to more people, and thus a viable alternative to more potential residents.

The rich mix of choices Dittmar and Poticha advocate goes beyond housing to other land uses and activities as well. A transit and pedestrian friendly neighborhood that includes activities particularly for non-driving populations like the young and old, is an equitable one. Even for drivers and more mobile groups, having a rich mix of activities can create substitution of car trips or allow for greater trip chaining.

\subsubsection{Place Making}

Perhaps the most important central goal about transit-oriented developments set out by Dittmar and Poticha is the idea of place making. Being next to transit physically is an asset, but in and of itself is not sufficient to make a person want to live somewhere. Dittmar and Poticha argue that a lack of attention on making transit-oriented developments pedestrian-friendly and attractive places as one of the greatest shortcomings of early generation transit-oriented developments.

When thinking about place making, the first thing to keep in mind is that places are for people. As such transit-oriented developments should foster interactions at the personal level, thus making convenience for pedestrians a central concern. They argue that when planning for the connectivity of a development, planners should consider how people travel by foot, bicycles, public transportation, and automobiles, in that order. 
One way places can be enhanced is by taking advantage of surroundings. When making places, attention should be cast to "utilize each site's intrinsic resources—-the climate, landform, landscape, and ecology — to maximize energy conservation and amenity.”

\subsection{3a. Typology of Transit-Oriented Development}

Exactly what kind of place a given transit oriented development should be varies from project to project. Different developments are located in different places, with different surroundings, and different proximities to job centers. Dittmar and Poticha identify six different settings where transit-oriented developments are generally built, which they call a General Typology of TOD Places Within a Metropolitan Region. These six settings include Urban Downtown, Urban Neighborhood, Suburban Town Center, Suburban Neighborhood, Neighborhood Transit Zone, and Commuter Town locations. A grid of characteristics for each of these settings is shown below in Table 2.14.

Urban Downtown - The roles of central cities are changing. While still important as job centers, other jobs centers are forming in satellite centers around cities, and central cities are instead growing in their prominence as civic and cultural centers. This is attracting new residents who want to be close to this activity. With the diversity of roles urban downtowns are now playing, there is also diversity in how development should be oriented in downtowns. Transit service must also do many things, traditionally shuttling commuters in and out, but also connecting passengers to other non-work related places of interest, and meeting the needs of residents. Recommended service headways in urban downtowns should be less than 10 minutes. 
Urban Neighborhoods - The primary blocks of medium-to-high density, and often times affordable housing in a region, urban neighborhoods, as Dittmar and Poticha put it, “Form the backbone of a compact, transit-friendly region.” Often organized off extensions of downtown street grids, transit oriented developments here are well integrated on a pedestrian scale. They also often have deep historic routes which can be an asset, as some urban neighborhoods are destinations themselves. Recommended service headways are 10 minutes during peak hours and 20 minutes during off-peak hours.

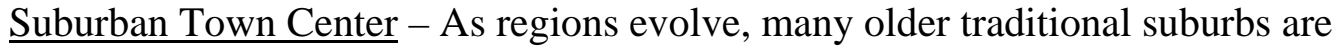
developing beyond just bedroom communities. These communities are seeing greater agglomeration of jobs, retail, and entertainment. Transit-oriented development in suburban town centers should support and contain these new agglomerations. They should also be particularly connected, both to traditional regional centers that they have been traditionally subordinate to, as well as other suburbs which are becoming subordinate to it. With activity not just during work hours, suburban town centers are recommended to have greater than 10 minute service headways during peak hours and 10-15 minute service headways off-peak.

Suburban Neighborhood - This setting is marked by suburban neighborhoods with access either to a regional sub-center, like a suburban town center, or to an urban downtown itself. Transit-oriented development here would potentially include some increased 
density adjacent to the station tapering down to more traditional suburban single-family residential, as well as some neighborhood retail space. Recommended service headways are 20 minute or less during peak hours and 30 minute or less during off-peak hours.

Neighborhood Transit Zone - These are areas surrounding basic local stops on bus, streetcar, or light-rail lines in mostly residential settings. There may be some neighborhood retail, or small office space. Transit-oriented development in this area could include compact light residential development like townhomes. Recommended service headways in this zone are 25-30 minutes.

Commuter Town - This community is more of a free-standing small town, outside the general urban and suburban stretches of a region. However, this type of community is located within reach of commuter rail or bus service to the adjacent region. Transitoriented development in this type of place would be in a "main-street" style that serves primarily as the stand-alone center of the town, but also provides access and some service to commuters. Such commuter towns are likely only to support peak-period service. 
Table 2.14

General Typology of TOD Places Within a Metropolitan Region

\begin{tabular}{|c|c|c|c|c|c|c|}
\hline TOD Type & Land-Use Mix & $\begin{array}{l}\text { Minimum } \\
\text { Housing } \\
\text { Density }\end{array}$ & $\begin{array}{l}\text { Housing } \\
\text { Types }\end{array}$ & Scale & $\begin{array}{l}\text { Transit } \\
\text { Modes }\end{array}$ & Frequencies \\
\hline $\begin{array}{l}\text { Urban } \\
\text { Downtown }\end{array}$ & $\begin{array}{l}\text { - Primary office } \\
\text { center } \\
\text { - Urban } \\
\text { entertainment } \\
\text { - Multifamily } \\
\text { housing } \\
\text { - Retail }\end{array}$ & $\begin{array}{l}>60 \\
\text { units/acre }\end{array}$ & $\begin{array}{l}\text { - Multi- } \\
\text { family } \\
\text { - Loft }\end{array}$ & High & All modes & $<10$ minutes \\
\hline $\begin{array}{l}\text { Urban } \\
\text { Neighborhood }\end{array}$ & $\begin{array}{l}\text { - Residential } \\
\text { - Retail } \\
\text { - Class B } \\
\text { Commercial }\end{array}$ & $\begin{array}{l}>20 \\
\text { units/acre }\end{array}$ & $\begin{array}{l}\text { - Multi- } \\
\text { family } \\
\text { - Loft } \\
\text { - Townhm. } \\
\text { - Single } \\
\text { Family }\end{array}$ & Medium & $\begin{array}{l}\text { - Light-rail } \\
\text { - Streetcar } \\
\text { - Rapid Bus - } \\
\text { Local Bus }\end{array}$ & $\begin{array}{l}\text { - } 10 \text { minutes } \\
\text { peak } \\
\text { - } 20 \text { minutes } \\
\text { offpeak }\end{array}$ \\
\hline $\begin{array}{l}\text { Suburban } \\
\text { Center }\end{array}$ & $\begin{array}{l}\text { - Primary office } \\
\text { center } \\
\text { - Urban } \\
\text { entertainment } \\
\text { - Multifamily } \\
\text { housing } \\
\text { - Retail }\end{array}$ & $\begin{array}{l}>50 \\
\text { units/acre }\end{array}$ & $\begin{array}{l}\text { - Multi- } \\
\text { family } \\
\text { - Loft } \\
\text { - Townhm. } \\
\text { - Single } \\
\text { family }\end{array}$ & High & $\begin{array}{l}\text { - Rail } \\
\text { - Streetcar } \\
\text { - Rapid bus } \\
\text { - Local bus } \\
\text { - Paratransit }\end{array}$ & $\begin{array}{l}\text { - } 10 \text { minutes } \\
\text { peak } \\
\text { - } 10-15 \\
\text { minutes } \\
\text { offpeak }\end{array}$ \\
\hline $\begin{array}{l}\text { Suburban } \\
\text { Neighborhood }\end{array}$ & $\begin{array}{l}\text { - Residential } \\
\text {-Neighborhood } \\
\text { retail } \\
\text { - Local office }\end{array}$ & $\begin{array}{l}>12 \\
\text { units/acre }\end{array}$ & $\begin{array}{l}\text { - Multi- } \\
\text { family } \\
\text { - Townhm. } \\
\text { - Single } \\
\text { family }\end{array}$ & Moderate & $\begin{array}{l}\text { - Light-rail } \\
\text { - Rapid bus } \\
\text { - Local bus } \\
\text { - Paratransit }\end{array}$ & $\begin{array}{l}\text { - } 20 \text { minutes } \\
\text { peak } \\
\text { - } 30 \text { minutes } \\
\text { offpeak }\end{array}$ \\
\hline $\begin{array}{l}\text { Neighborhood } \\
\text { Transit Zone }\end{array}$ & $\begin{array}{l}\text { - Residential } \\
\text { - } \\
\text { Neighborhood } \\
\text { retail }\end{array}$ & $\begin{array}{l}>7 \\
\text { units/acre }\end{array}$ & $\begin{array}{l}\text { - } \\
\text { Townhome } \\
\text { - Single } \\
\text { family }\end{array}$ & Low & $\begin{array}{l}\text { - Local bus } \\
\text { - Paratransit }\end{array}$ & $\begin{array}{l}\text { - } 25-30 \\
\text { minutes } \\
\text { - Demand } \\
\text { responsive }\end{array}$ \\
\hline $\begin{array}{l}\text { Commuter } \\
\text { Town Center }\end{array}$ & $\begin{array}{l}\text { - Retail center } \\
\text { - Residential }\end{array}$ & $\begin{array}{l}>12 \\
\text { units/acre }\end{array}$ & $\begin{array}{l}\text { - Multi- } \\
\text { family } \\
\text { - Townhm. } \\
\text { - Single } \\
\text { family }\end{array}$ & Low & $\begin{array}{l}\text { - Commuter } \\
\text { rail } \\
\text { - Rapid bus }\end{array}$ & $\begin{array}{l}\text { - Peak } \\
\text { service } \\
\text { - Demand } \\
\text { service }\end{array}$ \\
\hline
\end{tabular}

Source: Dittmar and Poticha, 2004, Table 2.3

\subsubsection{Design and Parking}

Cervero offers a similar set of characteristics for successful transit-oriented developments as Dittmar and Poticha. He calls out three dimensions, or 3 D’s to make transit-oriented development work. These are density, design, and diversity (Tumlin and Millard-Ball, 
2003). Density and diversity are thoroughly emphasized by Dittmar and Poticha, with density as a key component of location efficiency, and diversity being gained by a rich mix of choices. Density and land use mixes are also key considerations in Dittmar and Poticha's typologies of transit-oriented developments.

The importance of the final dimension, design, goes back to the idea that transit-oriented developments should be like traditional developments in every way except for their accessibility to different modes of travel. Transit accessibility in and of itself is insufficient to attract residents, they must also be attractive. It is arguable that perhaps transit-oriented developments need to be more attractive and have better design than traditional neighborhoods as they must cater to and foster pedestrian activity.

A key concern that transit-oriented developments must juggle in order to achieve all three of these dimensions is the issue of parking. It is necessary to still provide some parking to residents of transit-oriented developments. Just as having neighborhoods with automobile-only access constrains its residents from reaching certain areas, so would noautomobile access. Providing zero parking for transit-oriented developments would ignore resident's occasional needs to access surrounding developments that require automobiles for access.

Beyond their residents, transit-oriented developments must also accommodate the needs of commuters driving in to use their adjacent transit stations. This is of particular 
importance around stations where transit-oriented development is proposed, but large parking supplies currently exist.

While some parking is necessary, providing excessive parking can be extremely detrimental to transit-oriented developments. Dedicating large swaths of land to parking can lower the density of development that can be built. Also, forcing pedestrians to cross through large areas of parking is one of the greatest barriers to walking (Daisa, 2004). In terms of design, Cervero notes that having less parking can enhance design by allowing a "finer grain of development." By this, Cervero argues that less parking allows for smaller block sizes, which in general allow for greater variety and interesting design (Tumlin and Millard-Ball, 2003).

Daisa and Seigman offer several suggestions to handle parking issues in transit-oriented developments. Both Daisa, and Seigman call for a general de-emphasis on parking. Daisa says that parking should be configured so that it does not dominate a transit-oriented development. To do this, he says that parking should be "oriented away from the public realm," in structures, underground, or sheathed behind buildings (Daisa, 2004). Seigman takes this a step further, proposing to abolish minimum parking requirements, and identifying specific maximum parking requirements. He proposes no more than 500 spaces for 1,000 workers (Seigman, 2003).

Both Daisa and Seigman also suggest “unbundling” parking. Usually in developments, whether commercial or residential, parking spaces are included in the sale or lease of 
units. In unbundling, units are sold or rented without being allocated parking spaces, but without being charged for them either. Instead, parking spaces are separated into their own market, where only those who need or desire parking can buy it separately, generally cutting down on parking requirements (Daisa, 2004).

In addition to their common proposals, Daisa suggests charging for parking. Such charges would be dependent on specific parking objectives. For instance, a retail development would have a parking scheme that would promote short-term parking. Daisa says that pricing parking appropriately may significantly reduce parking demand, anywhere between 10 and 30 percent (Daisa, 2004).

To serve commuters driving in to use transit stations, Daisa proposes the use of remote parking facilities for commuters to park off site. Ultimate access to stations would be provided via frequent shuttles or express bus service. This reserves land directly adjacent to transit stations for more intense development. Other suggestions by Daisa include creating parking districts to fund municipal parking facilities like garages in an area, and protection of surrounding neighborhoods from overflow parking through the use of residential parking permits in those areas.

\subsection{Using Accessibility as Measure for TOD Opportunities}

This study uses the concept of accessibility, and the quantified measure of the accessibility index, to determine the quality of opportunities for transit-oriented 
development. This is done because of the importance of accessibility for any transportation network, regardless of what mode it comes in.

Cervero, 2000 raises the idea of a shift from automobility planning to accessibility planning. Cervero writes: "Replacing automobility planning with accessibility planning means social and community considerations take precedence over individualistic ones. It also recognizes what cities are about, first and foremost - people and places, not movement” (Cervero, 2000).

Note, that Cervero's idea has a shift to accessibility as the end goal for transportation, and not necessarily transit as the end goal. Since the idea is a shift away from automobility planning, he is inferring that traditional, auto-oriented development lacks at providing accessibility. However, just as it is fair to point out the shortcomings of over-dependency on automobile travel and auto-oriented development, so is it fair to also investigate the effectiveness of alternative transit investments. Thus, if one mark on auto-oriented development is a lack of accessibility, it would be beneficial to see if transit can provide that accessibility.

Accessibility is also a good measure to evaluate transit investments with because of the tenuousness of transportation funding. Cervero, 2000, also mentions that in the United States, "Highway construction dollars are pegged to the steady stream of gasoline tax receipts whereas public transport support is subject to whims of political brokering” (Cervero, 2000). 
Among the points raised earlier in this chapter on auto-oriented transportation and land use versus transit-oriented transportation and land use are issues like energy intensity, long term development costs, and latent demand, among others. As strong and as valid as these cases are, these cannot necessarily be described as hot button political issues.

What may be more politically appealing is customer satisfaction, which can come from providing good accessibility, and making it possible for people to do more activities and want to ride. So, with transit funding challenged, when extensions are built, they ought to have the maximum accessibility benefit possible, to strengthen the case for further extensions. This is particularly important if other justifications for transit, however valid, like the other ones listed previously, are less able to make the case.

Blumberg and Ong, 1998, discover that having good accessibility has strong benefits in its own right. They found that in their case study of Los Angeles, increasing accessibility to jobs contributes to decreasing enrollment in welfare and can thus help promote socioeconomic equity. They cite that this result is consistent with several other pieces of research from the early to mid-1990s looking at employment opportunities and welfare use.

Cervero, Tsai, et al., 2002, also highlights an additional accessibility-related equity issue in California. They find transit accessibility lacking in reverse commute directions, with particularly strong impacts on low-income reverse commuters. Low-income workers make reverse commutes at approximately double the rate of all workers in general. Many 
of these workers do not own cars and thus face exceedingly long travel times, up to four times longer than automobiles, on public transit networks oriented in the standard commute network.

\subsection{Measuring Accessibility: Focus on Work Trips}

The analysis of accessibility of transit stations in this study will focus on access to jobs from each location. This is a function of the significance of home-based trips to and from work. While these home-based work trips do not account for the most number of trips people make, they account for the largest amount of travel by distance the average people make. Work trips tend to be the longest trips people make, and are getting longer. Furthermore, unlike other trip types like shopping or social trips, for most people, the work trip has a set end location.

The 2035 Regional Transportation Plan by the San Francisco Bay Area Metropolitan Transportation Commission includes a Travel Forecast report that looks at travel characteristics by trip type. The Travel Forecast breaks down trips into home-based work, home based social/recreations, home-based school (of three types), home-based shopping/other, and non-home based trips. The report includes estimates for trip characteristics in 2006 and projects trip characteristics in 2035. Characteristics for 2035 are projected assuming the current transportation network is in place as well as projects slated in the 2007 MTC Traffic Improvement Program. 
In 2006, Home-Based Shop/Other Trips constituted the largest plurality of trips with 26.9\%. This was marginally greater than Non-Home-Based trips, 26.6\%, and HomeBased Work trips, 23.2\%. In terms of average weekly daily person miles however HomeBased Work trips were the largest plurality, and clearly so. Home-Based Work Trips made up $40.1 \%$ of miles traveled on an average weekday (see Table 2.15).

Table 2.15

Average Weekday Daily Trips and Person Miles of Travel: San Francisco Bay Area, 2006

\begin{tabular}{|l|r|r|r|r|}
\hline & $\begin{array}{r}\text { Average } \\
\text { Weekday Daily } \\
\text { Person Trips }\end{array}$ & Percent & $\begin{array}{r}\text { Avg. Weekday } \\
\text { Daily Person } \\
\text { Miles of Travel }\end{array}$ & Percent \\
\hline Home-Based Work, TOTAL & $4,921,732$ & $23.2 \%$ & $57,928,786$ & $40.1 \%$ \\
\hline Home-Based Shop/Other & $5,712,570$ & $26.9 \%$ & $29,191,233$ & $20.2 \%$ \\
\hline Home-Based Social/Recreation & $2,589,294$ & $12.2 \%$ & $15,846,479$ & $11.0 \%$ \\
\hline Non-Home-Based & $5,647,534$ & $26.6 \%$ & $31,569,715$ & $21.9 \%$ \\
\hline Home-Based Grade School & $1,299,177$ & $6.1 \%$ & $3,247,943$ & $2.2 \%$ \\
\hline Home-Based High School & 553,723 & $2.6 \%$ & $1,882,658$ & $1.3 \%$ \\
\hline Home-Based College & 532,348 & $2.5 \%$ & $4,785,809$ & $3.3 \%$ \\
\hline TOTAL & $21,256,378$ & $100 \%$ & $144,452,622$ & $100 \%$ \\
\hline
\end{tabular}

Source: Bay Area 2009 Regional Transportation Plan, Travel Forecast, Table D.4

The Travel Forecast report's projections for 2035 show these characteristics continuing into the future. Non-Home-Based trips are projected to become the largest share over Home-Based Shop/Other, however the roughly even distribution between those two trip types and Home-Based Work persist.

Home-Based Work trips are projected to maintain the clear plurality in average weekday person miles of travel. In fact, it begins to approach majority status with a projection of over 92 million average weekday daily person miles of travel or $45.6 \%$ (see Table 2.16). 
Table 2.16

Average Weekday Daily Trips and Person Miles of Travel: San Francisco Bay Area, 2035 Baseline Projection

\begin{tabular}{|l|r|r|r|r|}
\hline & $\begin{array}{r}\text { Average } \\
\text { Weekday Daily } \\
\text { Person Trips }\end{array}$ & Percent & $\begin{array}{r}\text { Avg. Weekday } \\
\text { Daily Person } \\
\text { Miles of Travel }\end{array}$ & Percent \\
\hline Home-Based Work, TOTAL & $7,776,528$ & $26.7 \%$ & $92,229,622$ & $45.6 \%$ \\
\hline Home-Based Shop/Other & $7,342,447$ & $25.2 \%$ & $37,813,602$ & $18.7 \%$ \\
\hline Home-Based Social/Recreation & $3,362,867$ & $11.6 \%$ & $19,201,971$ & $9.5 \%$ \\
\hline Non-Home-Based & $8,028,588$ & $27.6 \%$ & $42,150,087$ & $20.9 \%$ \\
\hline Home-Based Grade School & $1,417,325$ & $4.9 \%$ & $3,316,541$ & $1.6 \%$ \\
\hline Home-Based High School & 604,201 & $2.1 \%$ & $2,072,409$ & $1.0 \%$ \\
\hline Home-Based College & 576,337 & $2.0 \%$ & $5,336,881$ & $2.6 \%$ \\
\hline TOTAL & $29,108,293$ & $100 \%$ & $202,121,112$ & $100 \%$ \\
\hline
\end{tabular}

Source: Bay Area 2009 Regional Transportation Plan, Travel Forecast, Table D.4

To make their work trips, commuters in the Bay Area use automobiles predominantly, as is the case throughout the United States. 68\% of Bay Area commuters drove alone to work, and $12.9 \%$ of commuters carpooled. This makes a total of $80.9 \%$ of Bay Area workers that commute using passenger automobiles in 2000 (see Table 2.17).

Table 2.17

How Bay Area Workers Commute-to-Work, 2000

\begin{tabular}{|c|c|c|c|c|c|c|}
\hline $\begin{array}{c}\text { Drive } \\
\text { Alone }\end{array}$ & $\begin{array}{c}\text { Carpool } \\
\mathbf{2 +}\end{array}$ & $\begin{array}{c}\text { Transit } \\
\text { Passenger }\end{array}$ & $\begin{array}{c}\text { Walk } \\
\text { Only }\end{array}$ & $\begin{array}{c}\text { Work } \\
\text { at Home }\end{array}$ & $\begin{array}{c}\text { Other } \\
\text { Means }\end{array}$ & $\begin{array}{c}\text { Total } \\
\text { Workers }\end{array}$ \\
\hline $2,215,800$ & 419,300 & 315,700 & 104,400 & 132,600 & 70,700 & $3,258,500$ \\
\hline $68.0 \%$ & $12.9 \%$ & $9.7 \%$ & $3.2 \%$ & $4.1 \%$ & $2.2 \%$ & $100 \%$ \\
\hline
\end{tabular}

Source: MTC, Census 2000: The Journey to Work in the San Francisco Bay Area,Data Sum. 5, Table S-1

While automobile commuters are clearly the majority, the Bay Area has relatively fewer automobile commuters than the country as a whole. Nationwide, $87.9 \%$ of workers commute via automobile, a figure seven percentage points higher than the Bay Area (see Table 18). 
Table 2.18

How Workers Commute To Work For Selected Locations, 2000

\begin{tabular}{|l|c|c|c|c|c|c|}
\hline \multicolumn{2}{|c|}{} & $\begin{array}{c}\text { Chicago } \\
\text { CMSA* }\end{array}$ & $\begin{array}{c}\text { New York } \\
\text { CMSA* }\end{array}$ & $\begin{array}{c}\text { Los Angeles } \\
\text { CMSA* }\end{array}$ & $\begin{array}{c}\text { SF Bay Area } \\
\text { CMSA* }\end{array}$ & $\begin{array}{c}\text { United } \\
\text { States }\end{array}$ \\
\hline \multirow{2}{*}{ Total Commuters } & $4,218,108$ & $9,319,218$ & $6,767,619$ & $3,432,157$ & $128,279,228$ \\
\hline \multirow{3}{*}{ Total Auto } & Number & $3,435,893$ & $6,121,044$ & $5,929,546$ & $2,780,195$ & $112,736,101$ \\
\cline { 2 - 7 } & Percent & $81.46 \%$ & $65.68 \%$ & $87.62 \%$ & $81.00 \%$ & $87.90 \%$ \\
\hline \multirow{2}{*}{$\begin{array}{l}\text { Drove } \\
\text { Alone }\end{array}$} & Number & $2,972,853$ & $5,246,331$ & $4,901,201$ & $2,335,785$ & $97,102,050$ \\
\cline { 2 - 7 } Carpool 2+ & Percent & $70.48 \%$ & $56.30 \%$ & $72.42 \%$ & $68.06 \%$ & $75.70 \%$ \\
\cline { 2 - 7 } & Number & 463,040 & 874,713 & $1,028,345$ & 444,410 & $15,634,051$ \\
\hline \multirow{2}{*}{$\begin{array}{l}\text { Transit } \\
\text { Passenger }\end{array}$} & Number & $10.98 \%$ & $9.39 \%$ & $15.20 \%$ & $12.95 \%$ & $12.20 \%$ \\
\cline { 2 - 7 } & Percent & $11.49 \%$ & $24.90 \%$ & $4.66 \%$ & $9.48 \%$ & $4.70 \%$ \\
\hline \multirow{2}{*}{ Other } & Number & 297,380 & 878,019 & 522,529 & 326,750 & $9,475,424$ \\
\cline { 2 - 7 } & Percent & $7.05 \%$ & $9.42 \%$ & $7.72 \%$ & $9.52 \%$ & $7.40 \%$ \\
\hline
\end{tabular}

*CMSA = Consolidated Metropolitan Statistical Area

Source: US Census, 2000, Summary File 3, Table P30

Comparing the Bay Area to the Los Angeles metropolitan area, a region perceived as extremely auto-dominated, the Bay Area has 6.62\% fewer auto commuters in total, but also a smaller share of carpoolers. It is interesting to note that Los Angeles has a lower share of total auto commuters than the country as a whole, although just barely. While the Bay Area is relatively more balanced in commute modes than most of the country, it is definitely not quite in the same league as the nation's transit powerhouse, New York City, which has almost two and a half times the transit share of the Bay Area, $24.90 \%$ versus $9.48 \%$ respectively. 


\section{BACKGROUND AND MethodOLOGY}

\subsection{Study Area}

This study on the opportunities for and evaluation of transit-oriented development in the San Francisco Bay Area focuses mainly on the region's major rail lines. As shown with Dittmar and Poticha's typologies of transit-oriented developments in the previous chapter, there can definitely be transit-oriented developments along lower-volume, local serving systems, and non-rail public transit systems. However, for the sake of focusing on a manageable area for a study of this type, major emphasis is on systems which can carry high volumes of commuters, and thus have the opportunity to support large transitoriented developments.

Two existing inter-city, intra-region systems which fit this description are the Bay Area Rapid Transit system (BART) and the Cal Train system. Both systems currently connect two of the three largest cities in the region to each other. BART connects San Francisco and Oakland, with several branches that go into the greater East Bay (Alameda and Contra Counties), and northern San Mateo County. Caltrain connects San Francisco and San Jose on a single trunk, and serves the greater peninsula between the two cities, and the South Bay (San Mateo and Santa Clara Counties). 


\subsubsection{Other Lines Not Focused On}

Other rail systems in the Bay Area not covered in this study include the San Francisco MUNI Metro System, the Santa Clara County Valley Transit Authority Light Rail system, the Amtrak Capital Corridor line, and the Altamont Commuter Express line.

The MUNI and VTA light rail systems are not included due to the relatively lowercapacity nature of light rail, and the local service nature of the two systems. The Amtrak Capital Corridor line serves more as an inter-region rather than an intra-region system. The ACE can be classified as an inter-region or intra-region system depending on how the region is defined. Ultimately, ACE's penetration deep into San Joaquin County, which is not generally considered to be part of the Bay Area, and its relative scant service with only four round trips per day, ultimately led to it not being considered for detailed analysis in this study.

\subsubsection{BART}

BART is a heavy-rail system that operates five lines in the East Bay, San Francisco, and upper Peninsula. Four of the five lines serve San Francisco, and the fifth line is an intraEast Bay line. All five lines go through Oakland. San Francisco and Oakland are connected via the Transbay Tube, a tunnel that runs under the floor of San Francisco Bay to the north of the Bay Bridge (see Figure 3.1). 


\section{Figure 3.1}

Bay Area Rapid Transit (BART) System, 2009

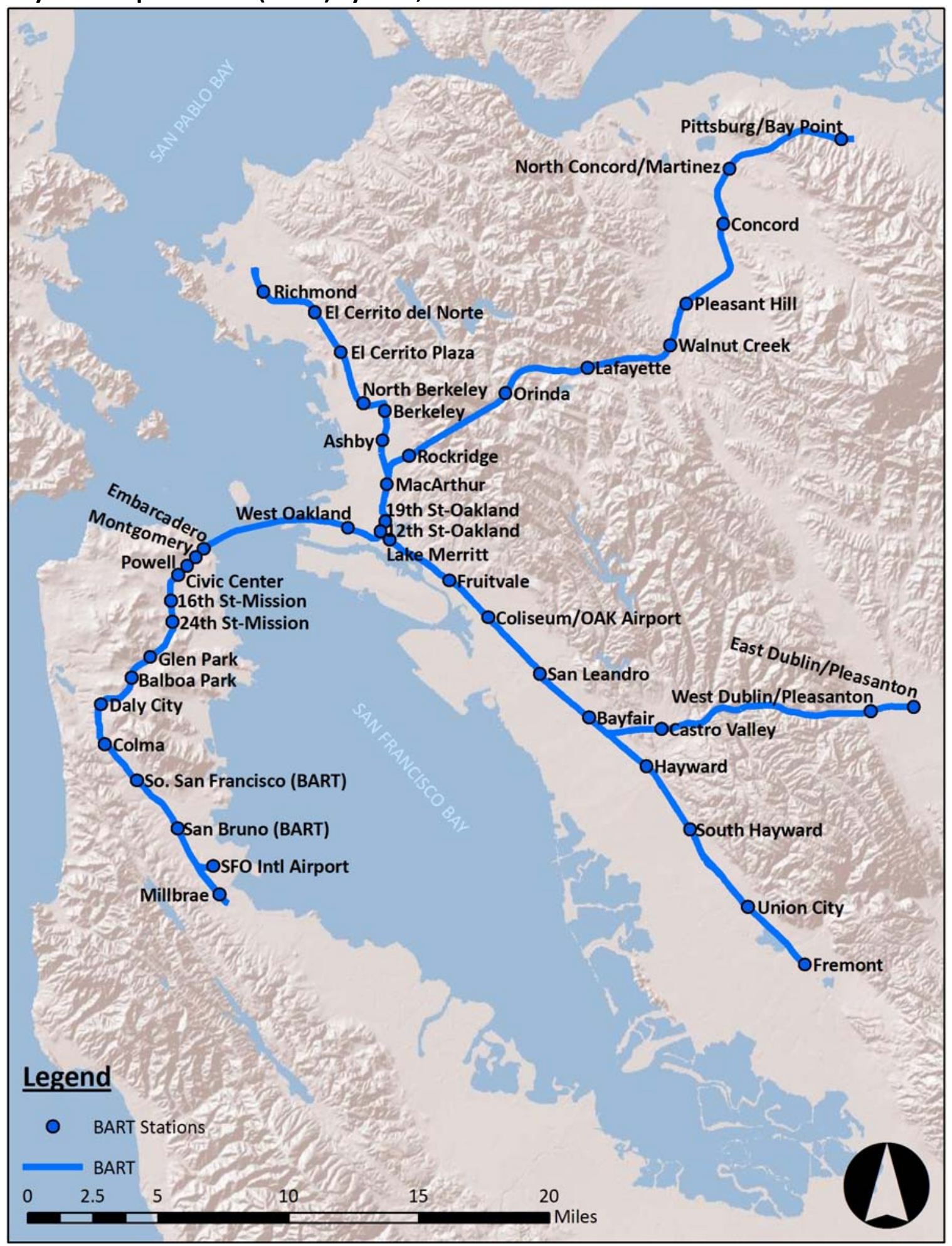

Source: SF-Metropolitan Transportation Commission, ESRI Shaded Relief Basemap 
The five lines are routed on 104 miles of track served by 44 stations (see Figure 1). At peak periods, trains operate at headways as short as 5 minutes. During off-peak periods and weekends, trains operate at headways no longer than 20 minutes. In 2008, BART attracted 357,775 riders per weekday (see Table 3.1).

Table 3.1

Bay Area Rapid Transit Basic Information

\begin{tabular}{|l|l|}
\hline Type & Heavy Rail \\
\hline Stations & 44 \\
\hline Lines & 5 \\
\hline Length & 104 miles \\
\hline Minimum Peak Hour Headway & 5 minutes \\
\hline 2008 Ridership & 357,775 per weekday \\
\hline
\end{tabular}

Downtown San Francisco is served by four stations, Embarcardero, Montgomery, Powell, and Civic Center. Downtown Oakland is served by three stations, Lake Merritt, $12^{\text {th }}$ Street, and $19^{\text {th }}$ Street. To the west and south of Downtown San Francisco, BART travels through other residential districts of the City, and cities in northern San Mateo County. This end of the BART system has two termini, San Francisco Internation Airport, and the Milbrae station, a transfer point with Caltrain.

Moving away from Oakland in the East Bay, BART breaks off in four directions, two to the North, and two to the South. To the North, one line serves bayside communities up to Richmond, and the other lines serves inland communities through the Lamorinda Area, Diablo Valley, and Delta area of Contra Costa County. To the South, one line serves bayside communities down to Fremont, with the other line splitting off the Fremont line at Bayfair east to the Tri-Valley area. In the Tri-Valley area, BART serves the East Dublin/Pleasanton Station. A second Tri-Valley station, the West Dublin/Pleasanton 
Station is under construction and slated to open in 2009. For the purposes of this study, it is assumed the West Dublin/Pleasanton is completed and included in any grouping of ‘existing’ stations.

BART's focus of service in San Francisco and the East Bay is a result of the historical structure of the Bay Area Rapid Transit District. Initially created by the California State Legislature as a five-county district, by 1962, the District was reduced to the three by the withdrawals of Marin County and San Mateo County. Then rural Santa Clara County was not included in the initial district. BART's original service, which began in 1972, was therefore focused in San Francisco, Alameda, and Contra Costa Counties.

\subsubsection{Caltrain}

Caltrain is a commuter rail system that runs on a single line from San Francisco in the north, through San Mateo County, into Santa Clara County, through San Jose, with a terminus in Gilroy in the south. The total length of the system is 77 miles which is served by 33 stations (see Figure 3.2 and Table 3.2).

On the single line of the system, Caltrain operates both local service trains, which stop at all stops, and express 'Baby Bullet” services which stop at selected higher-volume stations. Different Baby Bullet trains stop at different sets of higher-volume stations. During peak hours, Baby Bullet served stations can see headways between five minutes, (atypical - on stations where all Baby Bullets stop) and 30 minutes, and non-Baby Bullet served stations see peak headways of one hour. 


\section{Table 3.2}

\section{Caltrain Basic Information}

\begin{tabular}{|l|l|}
\hline Type & Commuter Rail \\
\hline Stations & 33 \\
\hline Lines & 1 \\
\hline Length & 77 miles \\
\hline Minimum Peak Hour Headway & 5 minutes - 1 hour* \\
\hline 2008 Ridership & 36,993 per weekday \\
\hline
\end{tabular}

*As low as 5 minutes for stations served by all Baby Bullet limited-stop express service. Up to 1 hour for stations not served by any Baby Bullet service. Baby Bullet trains do not stop at same stations.

It is of note that Caltrain does not pass directly through the downtown cores of the two major cities it serves as BART does. In San Francisco, Caltrain ends at $4^{\text {th }}$ Street and King Street in the Mission Bay District, one block from the San Francisco Giants stadium originally known as Pacific Bell Park, and two blocks from the Mission Bay campus of the University of California, San Francisco. Market Street, the main thoroughfare of downtown San Francisco sits eight blocks to the northwest across the Interstate 280 freeway. Rail access to the main sections of downtown San Francisco are available at $4^{\text {th }}$ and King via connecting service by the San Francisco MUNI Metro light rail system.

In San Jose, Caltrain grazes downtown San Jose with a stop at the central Diridon station. The body of downtown San Jose lies four blocks to the northeast, across the California Route 87 freeway. Diridon station is a major transfer station, serving VTA Light Rail, inter-regional Amtrak Service, and is the southern terminus of the Capitol Corridor and Altamont-Commuter Express lines.

Most of the communities Caltrain passes through in San Mateo County are generally lowdensity inner-ring suburbs. However, the line does pass through the regional sub-centers 
of San Mateo, and Redwood City, the county seat of San Mateo County. Caltrain also passes by two universities, Stanford University in Palo Alto, and Santa Clara University in Santa Clara, both in Santa Clara County. Connection to BART is available at the Millbrae station.

\section{Figure 3.2}

Caltrain System

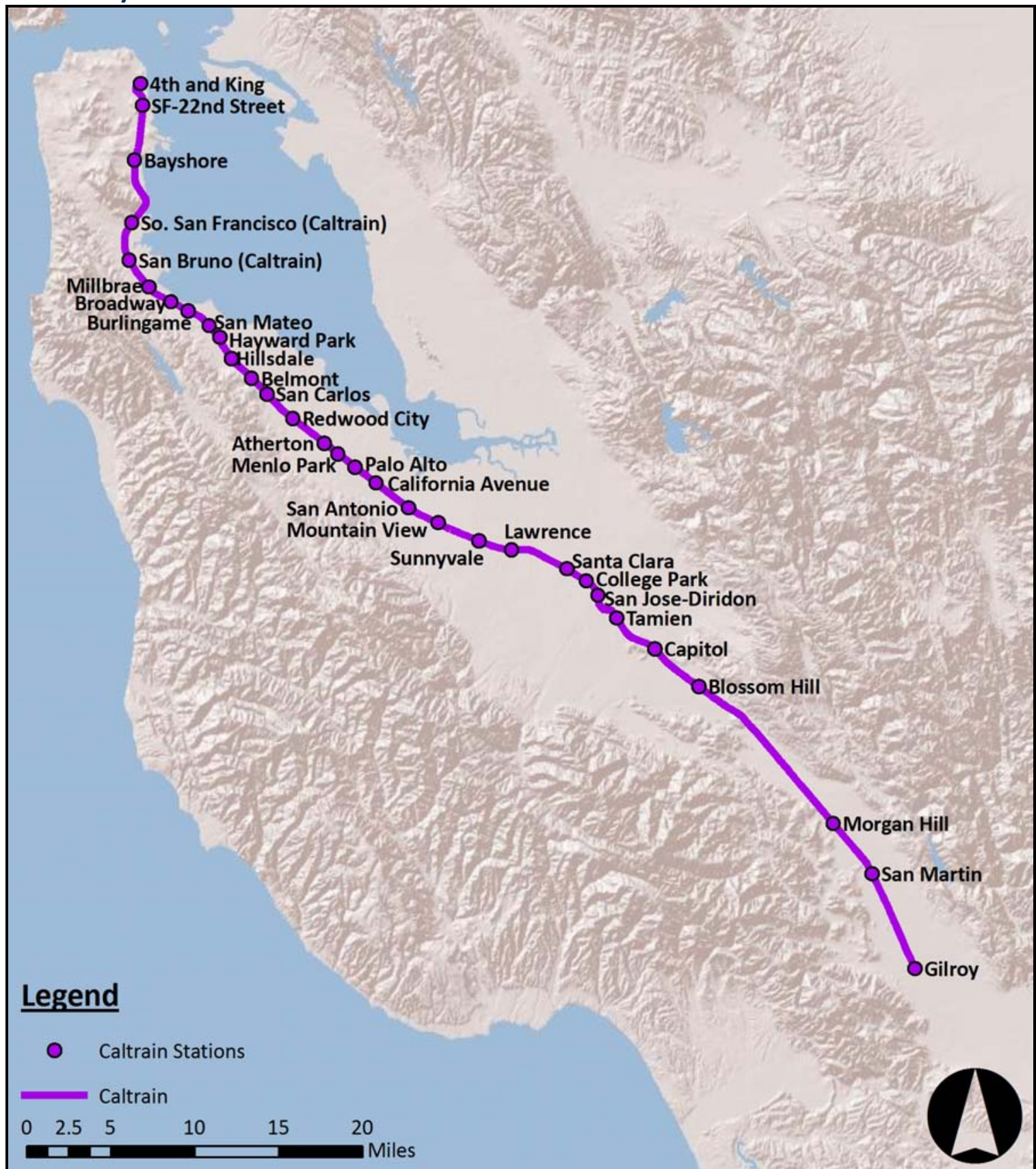

Source: SF-Metropolitan Transportation Commission, ESRI Shaded Relief Basemap 


\subsubsection{Future Lines}

In addition to looking at opportunities for transit-oriented development on existing rail lines, this study examines the potential along proposed rail lines and extensions. As with with existing rail lines, the scope of this study will focus on high capacity potential, intraregional systems. All proposed projects that are looked at are identified as Strategic Expansion programs in the San Francisco Metropolitan Transportation Commission's Transportation 2030 Plan (MTC, 2005).

\subsection{4a. eBART}

The eBART extension is a pre-construction project to extend commuter rail service to Sacramento River Delta cities in northern and northeastern Contra Costa County. As part of the original BART district, these communities have been paying into the BART system since its inception.

The eBART extension was approved by voters in 2004, with construction slated to begin in 2010. Phase I of the extension is slated to become operational in 2014 with two new stations east of the current Pittsburg/Bay Point terminus in Pittsburg and Antioch.

During deliberation of alternatives, it was decided that the eBART extension would not be served by traditional BART trains. Instead, the line would be served by diesel multiple unit trains. As such, the Phase I of the project also includes additions to the existing Pittsburg/Bay Point Station to allow for transfers from eBART trains to conventional 
BART trains. The potential full build of the eBART system considered in this study is a seven station extension from Pittsburg/Bay Point to Byron (see Figure 3.3).

\section{Figure 3.3}

Potential Full Build Alignment of eBART System

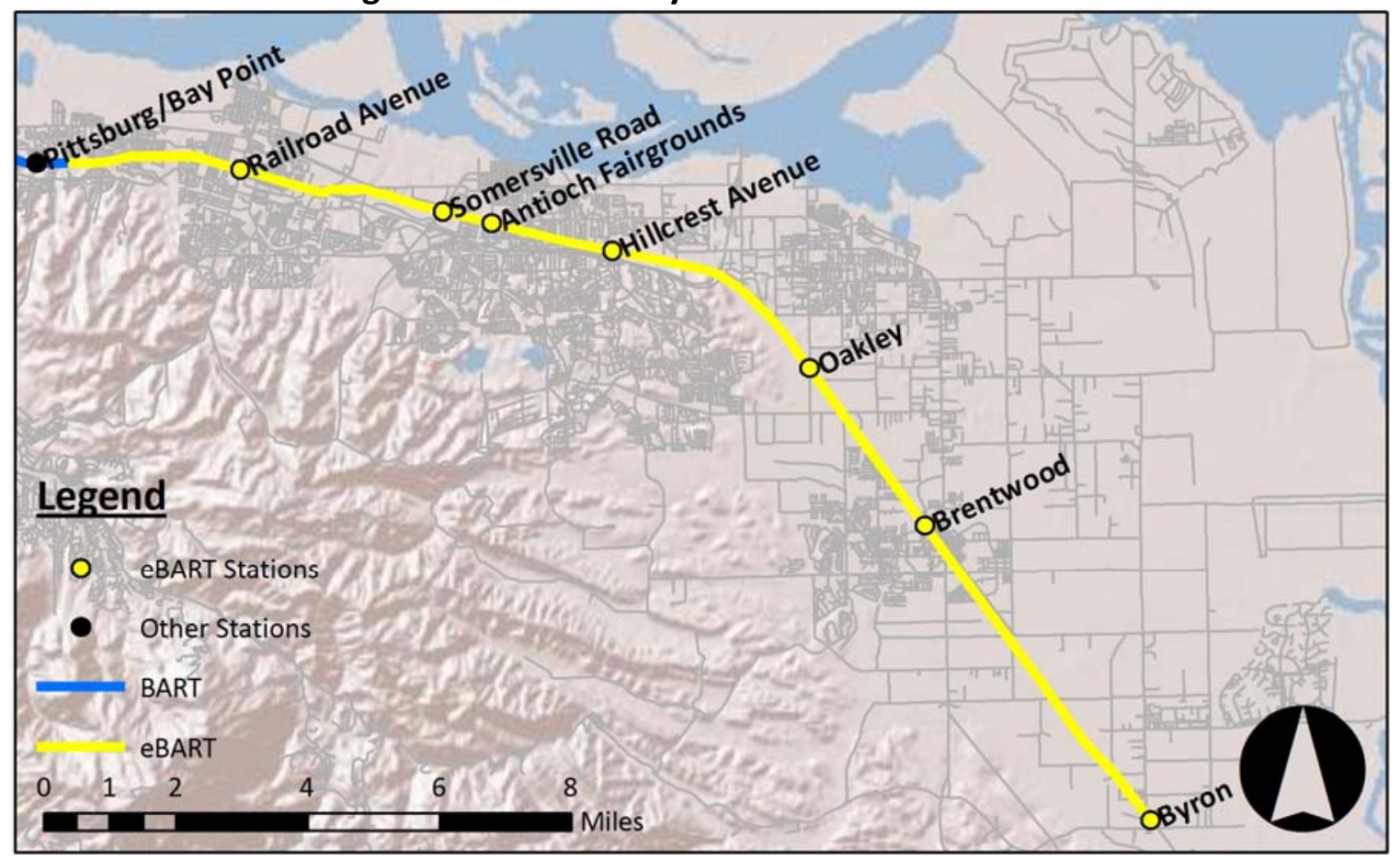

Source: SF-Metropolitan Transportation Commission, ESRI Shaded Relief Basemap

\subsection{4b. BART to Silicon Valley}

The BART to Silicon Valley project is a joint effort between BART and the Santa Clara County Valley Transportation Agency. If built, BART would continue from its current Fremont terminus, south into San Jose, through downtown San Jose, to a new terminus in Santa Clara.

To extend BART from Fremont to San Jose will actually require two separate projects. The first project is a 5.1 mile extension from the current Fremont station to the planned Warm Springs Station, in the southernmost Warm Springs district of Fremont. This 
project may also include an additional intermediary station in the Irvington district of Fremont.

The second project is the actual BART-VTA joint venture to San Jose. This project is a 15.1 mile extension from the planned Warm Springs Station to the new terminus in Santa Clara. The extension would include a stop in Milpitas, four or five stations in San Jose, and the end station in Santa Clara. The ambiguity in number of stations comes from the presence of two alternatives for downtown San Jose. One alternative includes only one downtown San Jose station, and another alternative has two downtown San Jose stations at Market Street and at the San Jose Civic Center/San Jose State University. For the purposes of calculations in this study, it is assumed that the two station alternative is selected. The extension would also have two transfer points to Caltrain, at the main Diridon Station terminal, and at Santa Clara (see Figure 3.4).

The Warm Springs extension as of early 2009 was in a pre-construction stage. Construction is slated to begin in mid-2009 with commencement of revenue service in 2014. The full extension to San Jose and Santa Clara as of early 2009 is in an engineering and draft environmental review stage. Following the passage of Santa Clara County Measure B in November 2008 to fund maintenance and operations, the project is expected to re-enter a process for federal approval. If approved, construction is slated to begin in 2010 with commencement of revenue service in 2018. 


\section{Figure 3.4}

\section{Proposed BART to Silicon Valley Extension}

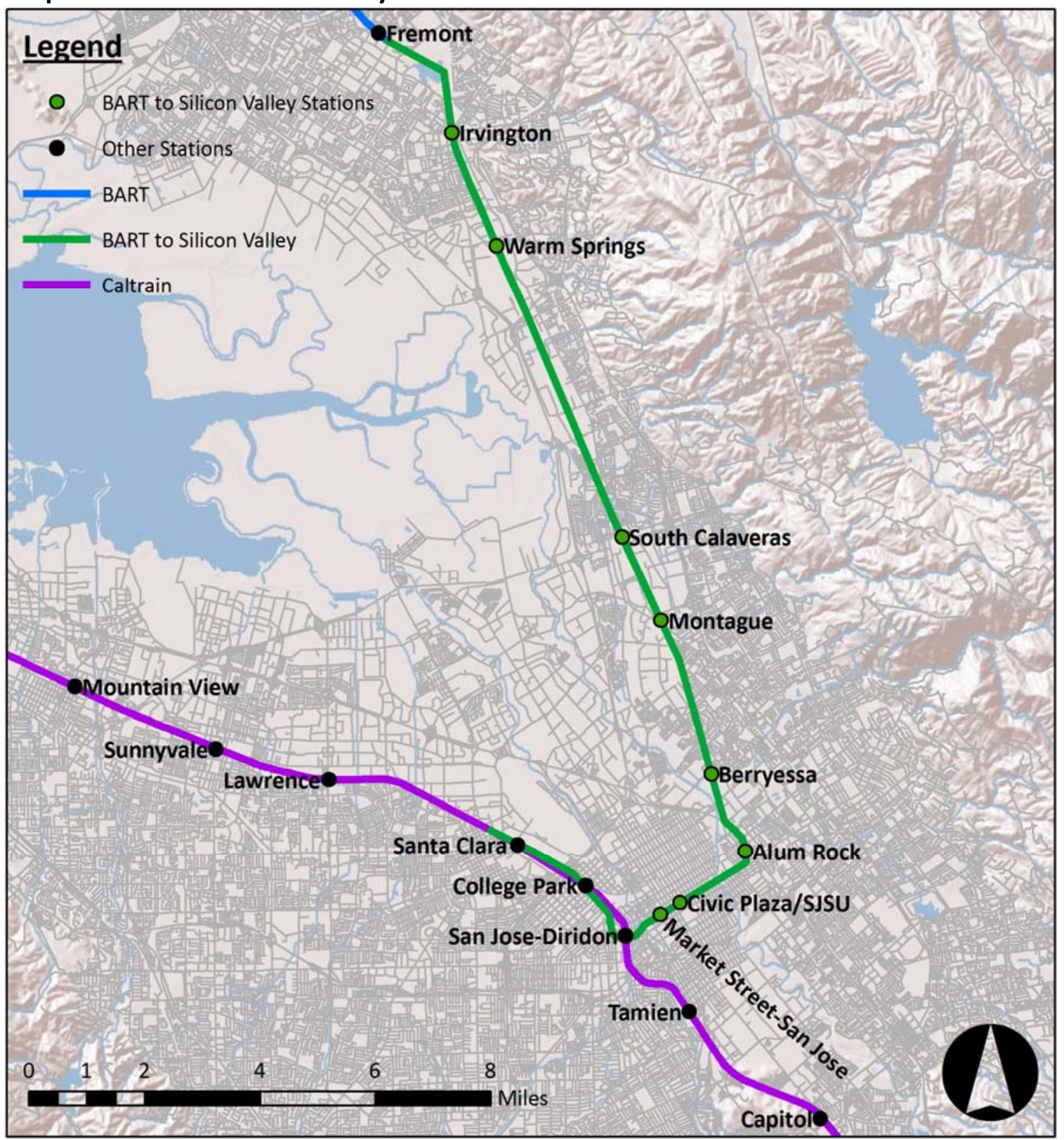

Source: SF-Metropolitan Transportation Commission, ESRI Shaded Relief Basemap

\subsection{4c. Caltrain to Downtown San Francisco}

The proposed Caltrain extension to downtown San Francisco would extend the system one station closer to the higher job concentration areas of the City. The new northern 
terminus of the system would be a rebuilt Transbay Terminal. Currently a bus only station, the Transbay Terminal would be rebuilt as an intermodal transit facility with an adjoining office tower. The extension would serve both Caltrain commuter trains and future high-speed rail trains.

The extension would be entirely underground, differing from the rest of the system which is mostly at grade. The extension would be tunneled under Townsend Street going Northeast, before turning onto $2^{\text {nd }}$ Street to the Northwest, and into the station (see Figure 3.5). Construction of the extension, which is in Phase II of the overall Transbay Terminal redevelopment project is slated to begin in 2012 and be complete in 2019.

\section{Figure 3.5}

\section{Proposed Caltrain to Downtown San Francisco Extension}

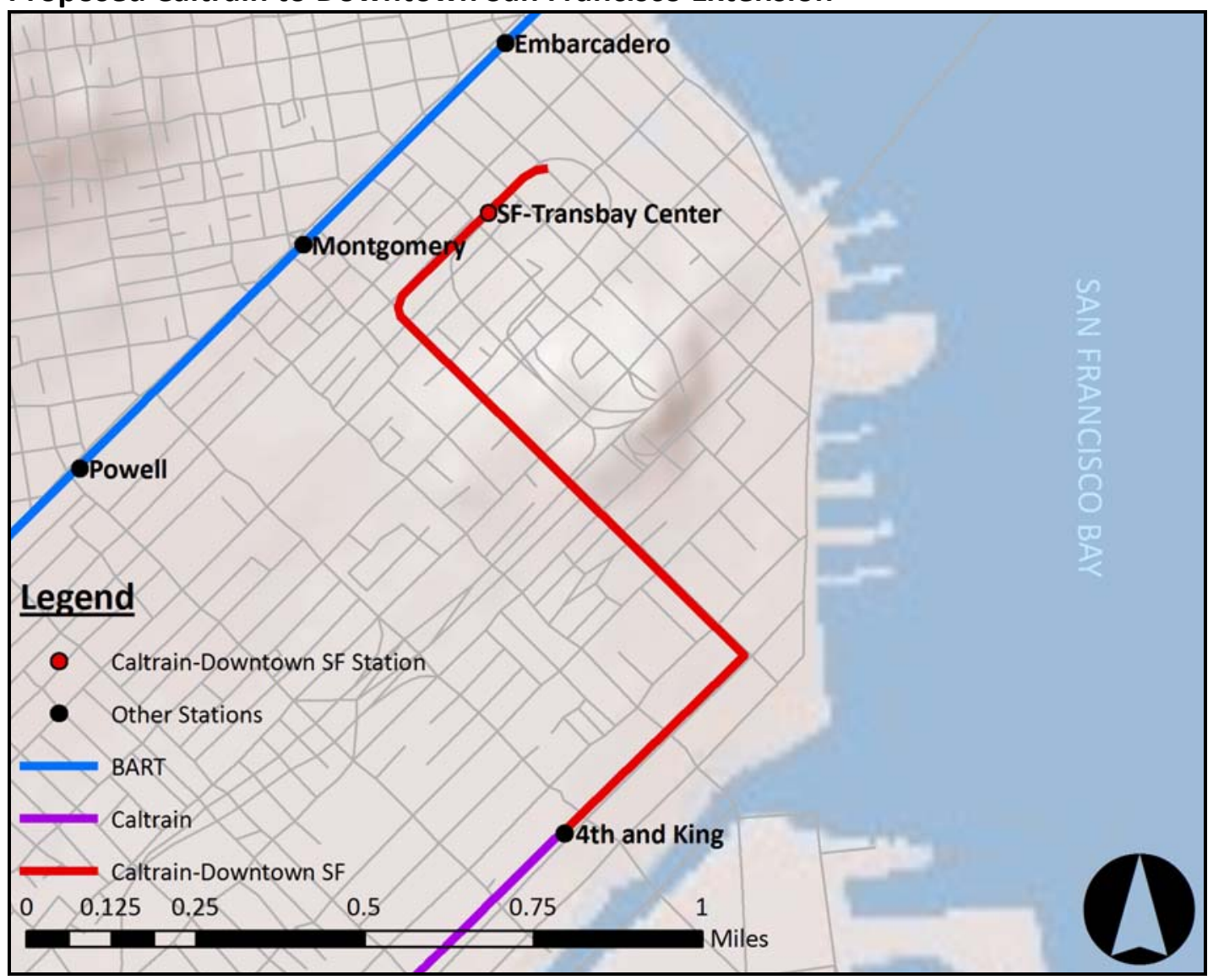

Source: SF-Metropolitan Transportation Commission, ESRI Shaded Relief Basemap 


\subsection{4d. Dumbarton Rail}

The Dumbarton Rail project would restore rail service across the middle of San Francisco Bay which has been discontinued since the 1980s. The project would involve the recommissioning and rehabilitation of the Dumbarton Rail Bridge, an abandoned bridge to the south of the State Route 84 Highway Bridge.

The system’s Eastern terminus would be on new platforms constructed at the Union City BART station. There would be three additional stations at Centerville Station in Fremont, Newark, and Willow Road in Menlo Park (see Figure 3.6). Trains on the system would be conventional commuter rail trains, and as such could hop onto the Caltrain right of way on the Peninsula, serving both San Francisco to the North and San Jose to the South.

\section{Figure 3.6}

Proposed Dumbarton Rail System

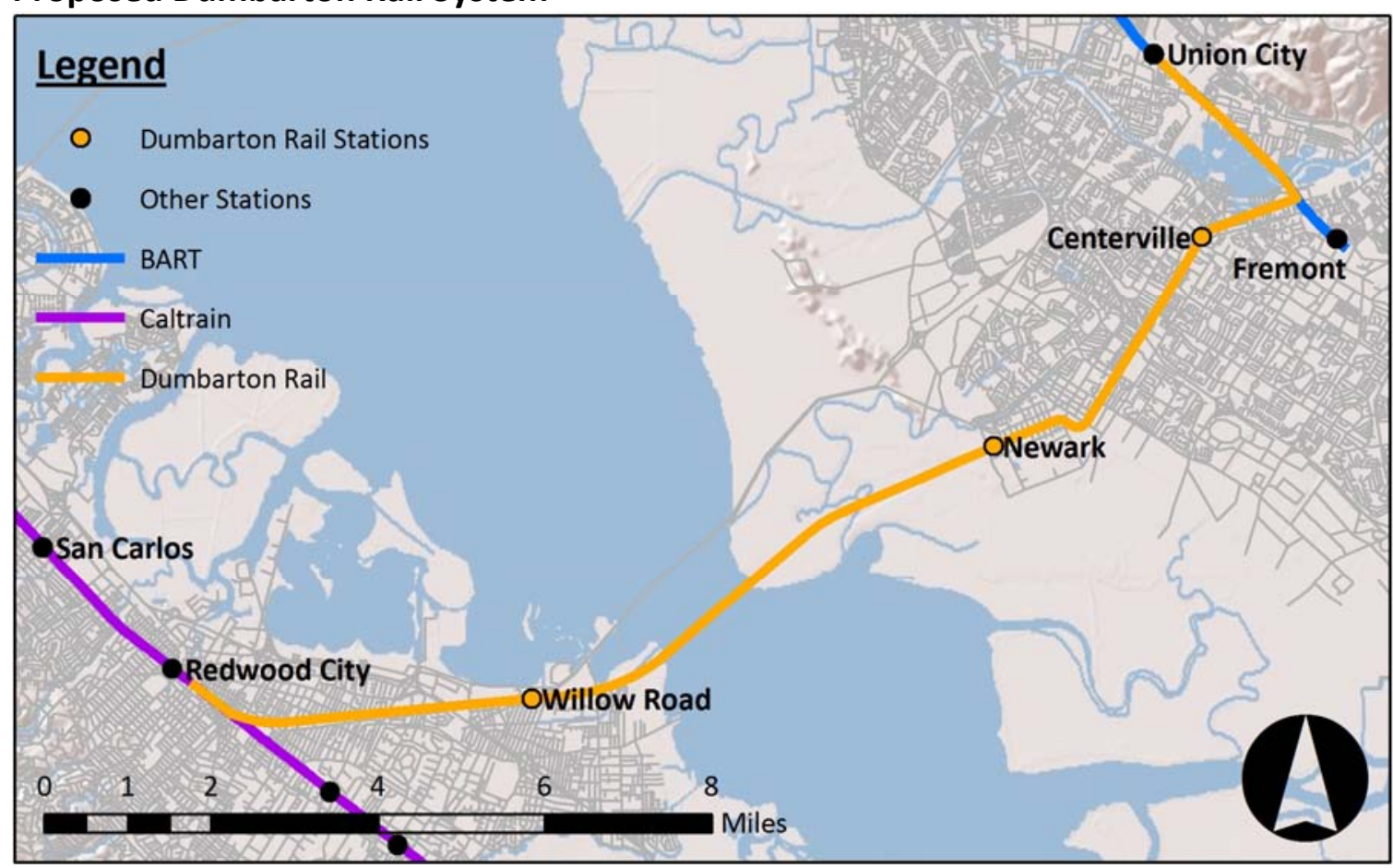

Source: SF-Metropolitan Transportation Commission, ESRI Shaded Relief Basemap 


\subsection{Measuring TOD Opportunities: Accessibility Indices}

The main tool used in this study to quantify opportunities for TOD around Bay Area rail transit stations is the accessibility index. The accessibility index is an application of the gravity model of transportation planning, and is derived from the physical science concept of gravitation. Issac Newton's Law of Universal Gravitation states that the force of gravity between two bodies is proportional to their mass and inversely proportional to their distance. The greater the gravitational force between the masses, the greater the attraction that exists between them.

The gravity model, as used in transportation, holds that the attraction between two locations, or the number of trips between them, is proportional to the size of the locations and inversely proportional to their distance. The greater the attraction between the two places, the more trips there are between them, and thus the more accessible the two places can be considered to each other.

Thus, accessibility can generally be described by the following function:

$$
\text { Accessibility }=\frac{\text { Size of Attraction }}{\text { Distance }}
$$

The size of attraction in this study will be the number of jobs surrounding rail stations. As detailed in the literature review chapter, the home based work trip holds the largest share of total trips made, and holds an even larger share of total miles traveled. So, at a given distance, the greater number of jobs at a station, the greater it will contribute to the accessibility index. 
It is of note that every station on the Bay Area rail transit system will be considered as both a potential TOD site and as a source of jobs for other stations. When referring to the residential opportunities of a given station, it will be referred to as a potential TOD site. However, when referring to the residential opportunities of a different station in the system, the original station is referred to as a source of jobs for that different station.

Residents who might live in a potential TOD site may access jobs at any other station on the system, not just at particular ones. Thus, the total accessibility of a potential TOD site is not the accessibility index between that potential site and another given station but rather the sum of the accessibility indices between that potential site and all other stations.

The accessibility index for a potential TOD site can thus be generally described by the ollowing function:

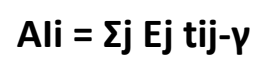

Where: $\quad \mathrm{Al}_{\mathrm{i}}=$ Aggregate accessibility index of potential TOD site, $\mathrm{i}$ $E=$ Number of jobs at reachable station, $j$ $\mathrm{t}_{\mathrm{ij}}=$ Distance between potential TOD site, $\mathrm{i}$ and reachable station, $\mathrm{j}$ $\mathrm{Y}=$ Inverse relationship between distance and accessibility

\subsubsection{Size of Attraction: Jobs Component}

The size of attractions in this study are based on job counts surrounding the stations and are 2006 estimates as derived from the US Census Local Employment Dynamics (LED): On The Map Tool (http://lehd.did.census.gov/led/datatools/onthemap3.html). The LED: On The Map Tool allows users to select data on where workers live and are employed for 
custom user-defined geographies, beyond standard census geographies like censusdesignated places and tracts and blocks.

Job counts were pulled for within three distances away from rail transit stations, one quarter mile, one half mile, and one mile. These distances were pulled under the working assumption that most commuters will probably be willing to walk a quarter mile distance, the average commuter may be willing to walk within a half mile distance, and some commuters could walk up to a one mile distance. Assuming a 3 mile per hour average walking speed, a person can travel a quarter mile in 5 minutes, a half mile in 10 minutes, and one mile in 20 minutes.

At both one quarter mile and half mile radii, the Montgomery BART Station in Downtown San Francisco had the largest number of jobs. There were 64,162 jobs within one quarter mile and more than double, 159,034 jobs within one half mile. The San Francisco-Transbay Center and Powell BART stations were ranked second and third respectively at the two distances. Within one mile, Powell becomes the largest job center at 265,726 jobs, with Montgomery and Transbay Center moving down one ranking (see Table 3.3).

Generally, at each distance, there are larger job centers in San Francisco than San Jose and Oakland. The only stations outside of the three main regional centers to rank in the top 10 at any distance are Berkeley, $7^{\text {th }}$ at one quarter mile and $9^{\text {th }}$ at one half mile, and Walnut Creek, $10^{\text {th }}$ at one quarter mile. 
Table 3.3

Top 10 Job Centers Around Bay Area Rail Transit Stations, 2006

\begin{tabular}{|c|c|c|c|c|c|c|}
\hline \multirow{2}{*}{ Rank } & \multicolumn{2}{|c|}{ Quarter Mile Radius } & \multicolumn{2}{c|}{ Half Mile Radius } & \multicolumn{2}{c|}{ One Mile Radius } \\
\cline { 2 - 7 } & Station & \# of Jobs & Station & \# of Jobs & Station & \# of Jobs \\
\hline 1 & Montgomery & 64,162 & Montgomery & 159,034 & Powell & 265,726 \\
\hline 2 & SF-Transbay Ctr. & 44,596 & SF-Transbay Ctr. & 143,250 & Montgomery & 246,163 \\
\hline 3 & Powell & 27,635 & Powell & 83,580 & SF-Transbay Ctr. & 234,672 \\
\hline 4 & Market St-SJ & 25,877 & 12 th St-Oakland & 46,388 & Embarcadero & 185,457 \\
\hline 5 & 12 th St-Oakland & 20,435 & 16 th St-Mission & 45,137 & Civic Center & 161,010 \\
\hline 6 & 19 th St-Oakland & 14,856 & 19 th St-Oakland & 37,994 & 4th and King & 98,363 \\
\hline 7 & Berkeley & 10,343 & Civic Center & 37,936 & 16 th St-Mission & 91,518 \\
\hline 8 & Civic Center & 10,066 & Market St-SJ & 35,553 & 19 th St-Oakland & 73,860 \\
\hline 9 & SFO Intl Airport & 8,150 & Berkeley & 32,470 & 12 th St-Oakland & 70,520 \\
\hline 10 & Walnut Creek & 7,118 & Embarcadero & 31,785 & Lake Merritt & 68,117 \\
\hline
\end{tabular}

Source: US Census, Local Employment Dynamics (2009)

The fewest number of jobs at a quarter mile radius are around the proposed Oakley and Byron eBART stations, with zero and single digits respectively. Both stations also appear in the bottom five at a half mile radius, behind smallest center North Concord at 117 jobs.

Byron is the smallest job center within a one mile radius with 451 jobs (see Table 3.4).

Table 3.4

Smallest 5 Job Centers Around Bay Area Rail Stations, 2006

\begin{tabular}{|c|c|c|c|c|c|c|}
\hline \multirow{2}{*}{ Rank } & \multicolumn{2}{|c|}{ Quarter Mile Radius } & \multicolumn{2}{c|}{ Half Mile Radius } & \multicolumn{2}{c|}{ One Mile Radius } \\
\cline { 2 - 7 } & Station & \# of Jobs & Station & \# of Jobs & Station & \# of Jobs \\
\hline 5 & San Martin & 71 & Byron & 412 & South Hayward & 1,793 \\
\hline 4 & E. Dublin/Plsntn. & 70 & San Martin & 193 & Hillcrest Ave. & 1,704 \\
\hline 3 & Concord & 25 & Oakley & 192 & Pittsburg & 683 \\
\hline 2 & Byron & 4 & Pittsburg & 132 & San Martin & 610 \\
\hline 1 & Oakley & 0 & North Concord & 117 & Byron & 451 \\
\hline
\end{tabular}

Source: US Census, Local Employment Dynamics (2009)

Job counts for all 93 stations and potential station sites evaluated in this study are presented in the Appendix, Table X3.1. Job counts are shown graphically within one quarter mile in Figure 3.7, one half mile in Figure 3.8, and one mile in Figure 9. 


\section{Figure 3.7}

Number of Jobs Within One Quarter Mile of Bay Area Rail Stations, 2006

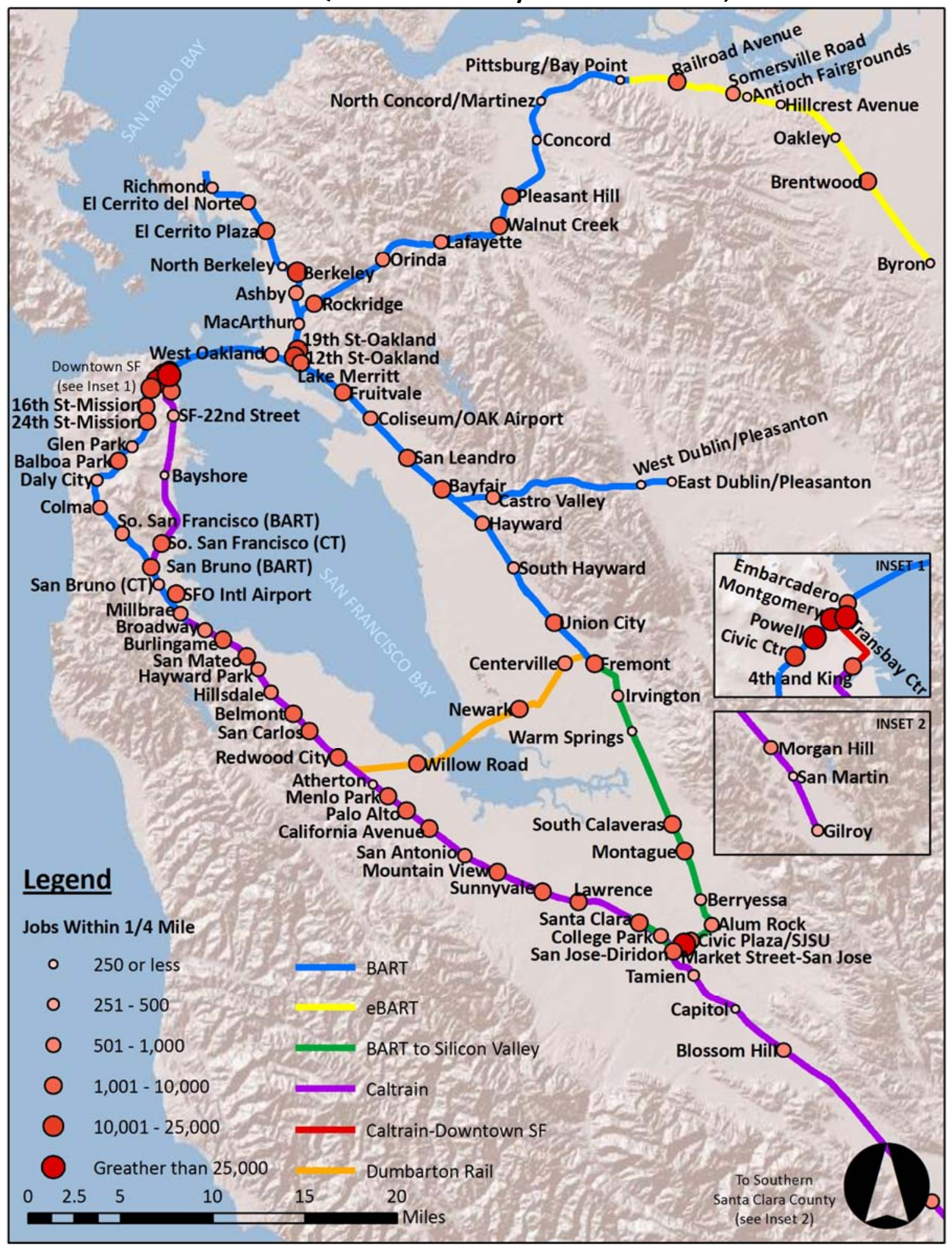

Source: U.S. Census (2006), SF-Metropolitan Transportation Commission, ESRI Shaded Relief Basemap 


\section{Figure 3.8}

Number of Jobs Within One Half Mile of Bay Area Rail Stations, 2006

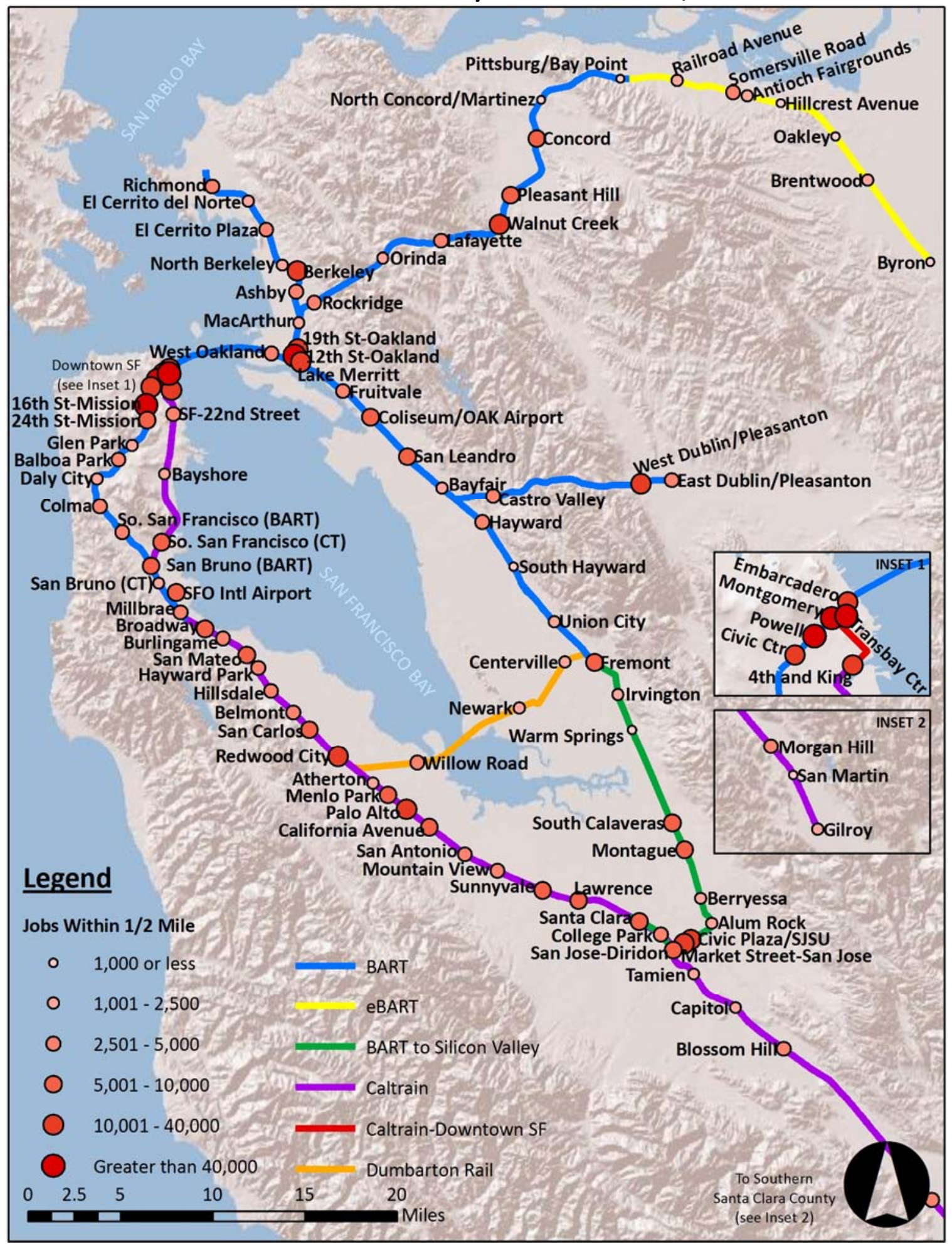

Source: U.S. Census (2006), SF-Metropolitan Transportation Commission, ESRI Shaded Relief Basemap 
Figure 3.9

Number of Jobs Within One Mile of Bay Area Rail Stations, 2006

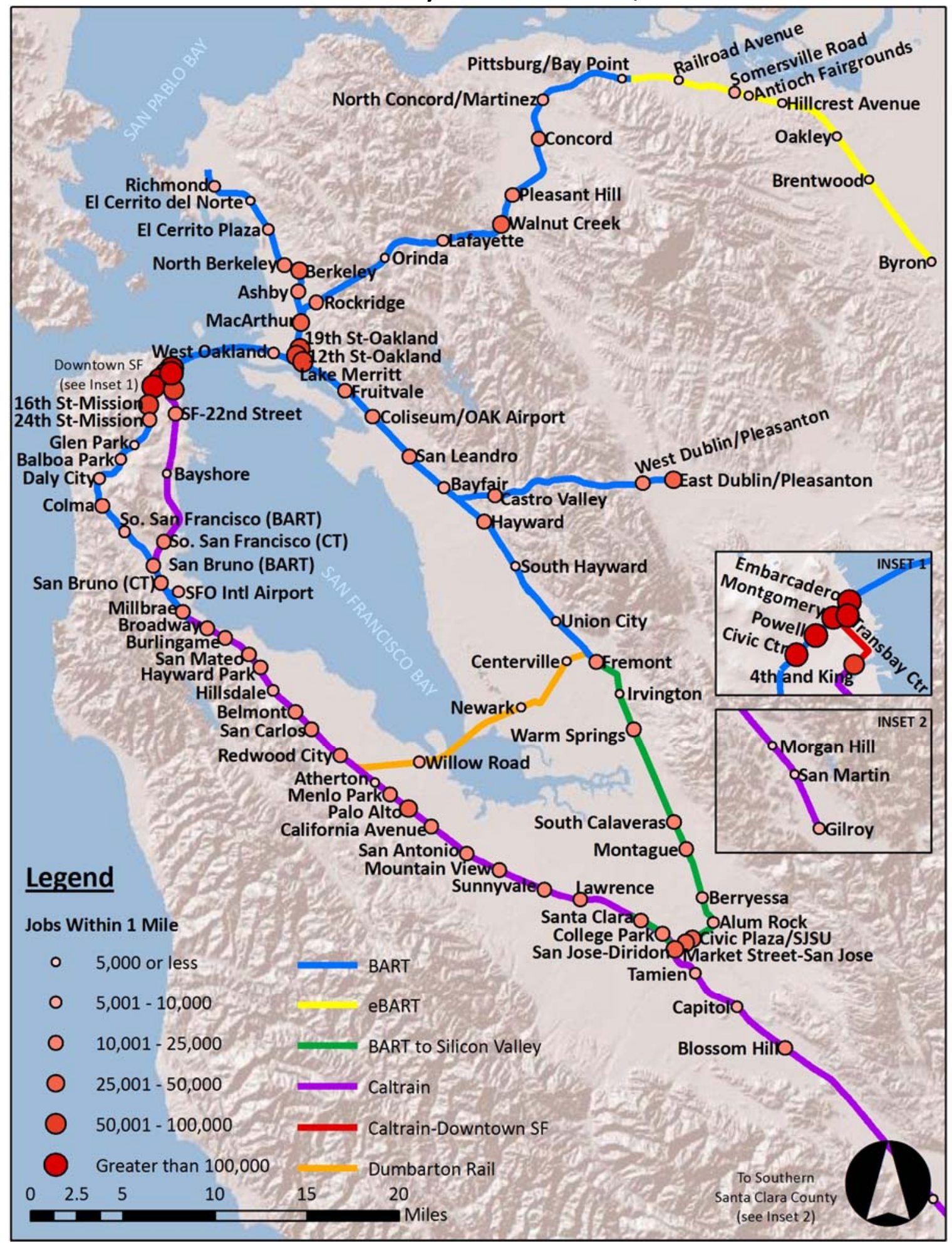

Source: U.S. Census (2006), SF-Metropolitan Transportation Commission, ESRI Shaded Relief Basemap 


\subsubsection{Friction Factor Component}

As previously mentioned, the accessibility between one station and another is inversely proportional to the distance. This is due to travelers generally being less willing to make a certain trip as the length of that trip increases. In terms of the accessibility index measurement, ‘distance’ can be interpreted several ways.

To be more precise, accessibility decreases as impedance increases. If a traveler is more greatly impeded traveling between two locations, the less likely they will make that trip. Physical distance is one type of impedance, but so are costs, like time cost and economic cost.

The numeric value of the level of impedance of travel is also known as the friction factor. The friction factor can be described by the portion of the accessibility index equation as follows:

$$
F_{f}=t_{i j}^{-Y}
$$

\footnotetext{
Where: $F_{f}=$ friction factor

$t_{i j}=$ Distance between potential TOD site, $i$ and reachable station, $i$

$Y=$ Inverse relationship between distance and accessibility
}

A default value for Y can be assumed as -1 in a non-calibrated application of friction factors. Travelers in different areas may behave differently, and have differing willingness to take certain trips. By surveying traveler behavior, transportation planners can come up with calibrated friction factors for an area. Calibrated friction factors for Bay Area travelers were produced in the BAYCAST-90 Travel Demand Model for the 
San Francisco Bay Area (Metropolitan Transportation Commission, 1997). In the BAYCAST-90 travel model, the characteristic of travel measured for impedance is time.

Travel times from station to station are derived from available time tables and station distance information. Time tables are available for the existing BART and Caltrain systems. Travel times for trips passing through the Caltrain line account for Baby Bullet express service. For the proposed systems where timetables do not yet exist, travel times are extrapolated based on how long BART or Caltrain trips cover similar distances. BART to Silicon Valley travel times are based on BART travel times. Caltrain to San Francisco and Dumbarton Rail travel times are based on Caltrain travel times. eBART is also based on Caltrain travel times as it is planned to run non-grade separated, nonelectrified rolling stock like Caltrain as opposed to grade-separated, electrified rolling stock like BART.

The friction factors from the BAYCAST-90 travel model are shown graphically compared to the generic $\mathrm{t}^{-1}$ value in Figure 3.10. It is of note that for the generic friction factors, the maximum friction factor is 1 , assuming that one minute is the shortest possible travel time. Friction factors for travel times greater than one minute are increasingly smaller decimals. In the BAYCAST-90 model, the maximum friction factor is 355,000 at a travel time of one minute. In Figure 10, the generic and BAYCAST-90 friction factors are drawn on differently scaled axes such that their maximum values are near equivalent. 
Both the generic and BAYCAST-90 friction factor curves are downward in shape, sloping increasingly down with travel time up to a point, before sloping decreasingly down with travel time as travel time approaches infinity. The two differ in that the BAYCST-90 friction factors decline at a slightly greater rate than the generic value.

Thus, Bay Area travelers are slightly less willing to make trips with increasing travel time than would be expected under default conditions. Values of BAYCAST-90 and generic friction factors are provided in the Appendix, Table X3.2 and X3.3.

\section{Figure 3.10}

Friction Factors from MTC BAYCAST-90 Travel Demand Study vs. Generic (Ff = T-1) values

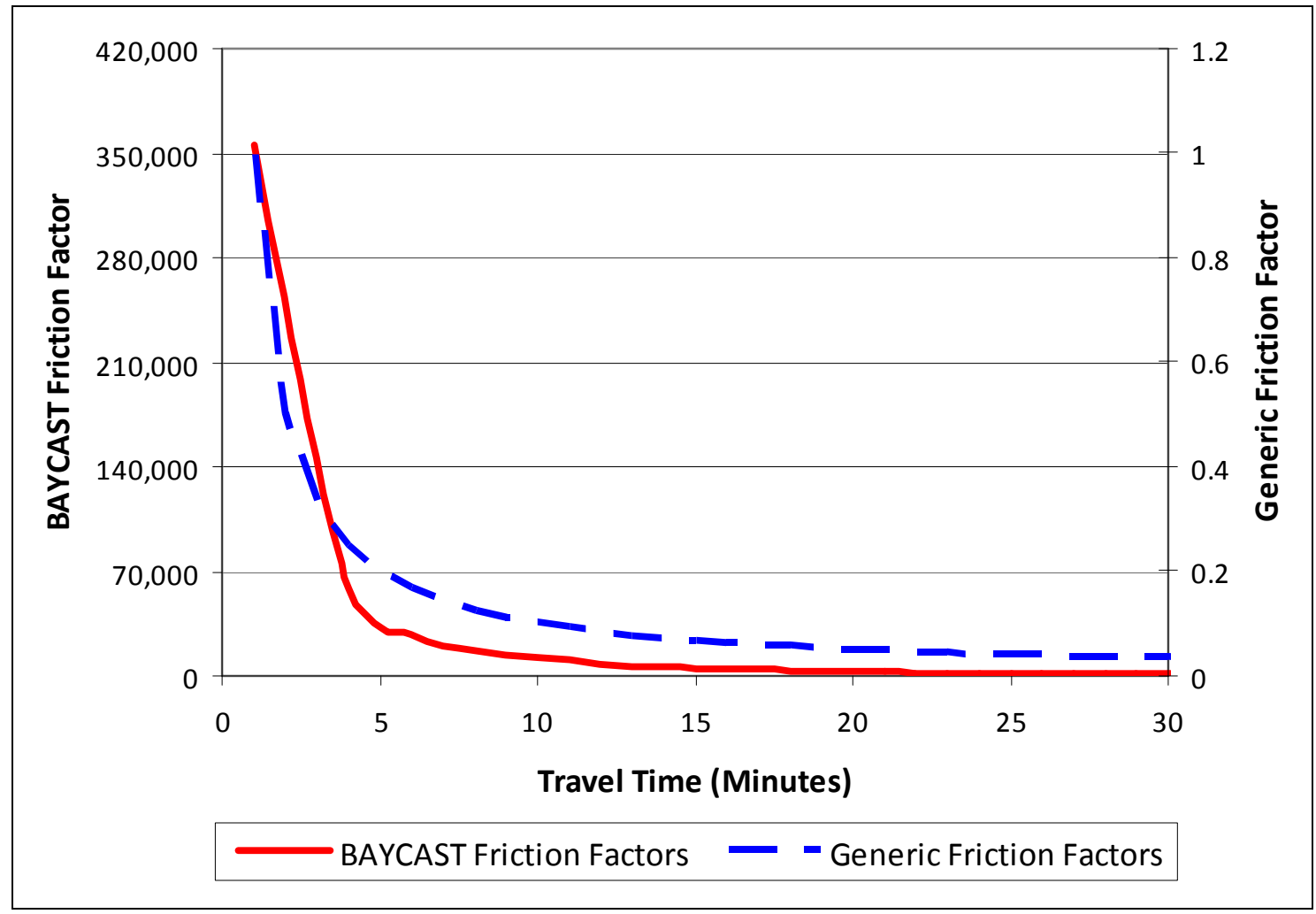

Source: SF-MTC BAYCAST-90 Travel Demand Study, Table 3 (1997)

\subsubsection{Scaling of Accessibility Index}


The number of jobs surrounding each individual ranges from zero to hundreds of thousands., however it can be into the six digits at some of the larger stations at a one mile radius. Generic friction factors can be no greater than one. The BAYCAST-90 model friction factors used in this study can also be up to six digits. A six digit job count multiplied by a six digit friction factor produces a 12 digit accessibility index.

To create more understandable accessibility index values, the raw product of jobs and friction factors are divided by one billion to produce smaller values. This purely a cosmetic difference as the accessibility indices are unit-less thus making only the relation between index values significant, and not their absolute values.

With this change, the accessibility indices, as presented in this report, can be described with the following equation:

$$
A I_{i}=\frac{\Sigma_{j} E_{j} t_{i j}^{-v}}{10^{9}}=\frac{\Sigma_{j} E_{j} F_{f}}{10^{9}}
$$

$$
\begin{array}{ll}
\text { Where: } & \mathrm{Al}_{\mathrm{i}}=\text { Accessibility index of origin station, } \mathrm{i} \\
& \mathrm{E}=\text { Number of jobs at reachable station, } \mathrm{j} \\
& \mathrm{t}_{\mathrm{ij}}=\text { Distance between origin station, } \mathrm{I} \text {, and destination station } \\
& \mathrm{Y}=\text { Inverse relationship between distance and accessibility } \\
& \mathrm{F}_{\mathrm{f}}=\text { Friction factor (from BAYCAST-90 travel model) }
\end{array}
$$

\subsection{Alternative Network Configurations}

Accessibility indices were calculated up to nine times for each station. They were calculated three times each for distance, and times each for the three alternative network configurations. The three configurations include different combinations of existing and 
proposed lines. Not all stations are in each configuration, so stations that are in only one or two configurations have their index calculated three or six times respectively.

The different combinations of lines in the three alternative network configurations produce system alignments with differing shapes and differing numbers of connections between the western and eastern half of the region.

Alternative Network Configuration A (see Figure 3.11) calculates accessibility on a network composed of the existing BART and Caltrain lines. Together, they form a trunk and branch shape with one bay crossing at the Transbay Tube between San Francisco and Oakland. One connection between BART and Caltrain is present at Millbrae.

Alternative Network Configuration B (see Figure 3.12) calculates accessibility on a network composed of the existing BART and Caltrain lines, plus BART to Silicon Valley extension, eBART extension, and the Caltrain to Downtown San Francisco extension. These systems form a loop of rail around San Francisco Bay with additional branches. With the closing of this loop, connections between BART and Caltrain occur at Millbrae directly, and at Diridon and Santa Clara on the BART to Silicon Valley extension.

Alternative Network Configuration C (see Figure 3.13) incorporates the lines on Alternative B plus Dumbarton Rail. This addition results in a loop, with a mid-bay crosslink, and branches. In this alignment, Dumbarton Rail acts as a fourth connection between BART and Caltrain. 
Figure 3.11

Alternative Network A: Existing System - BART and Caltrain

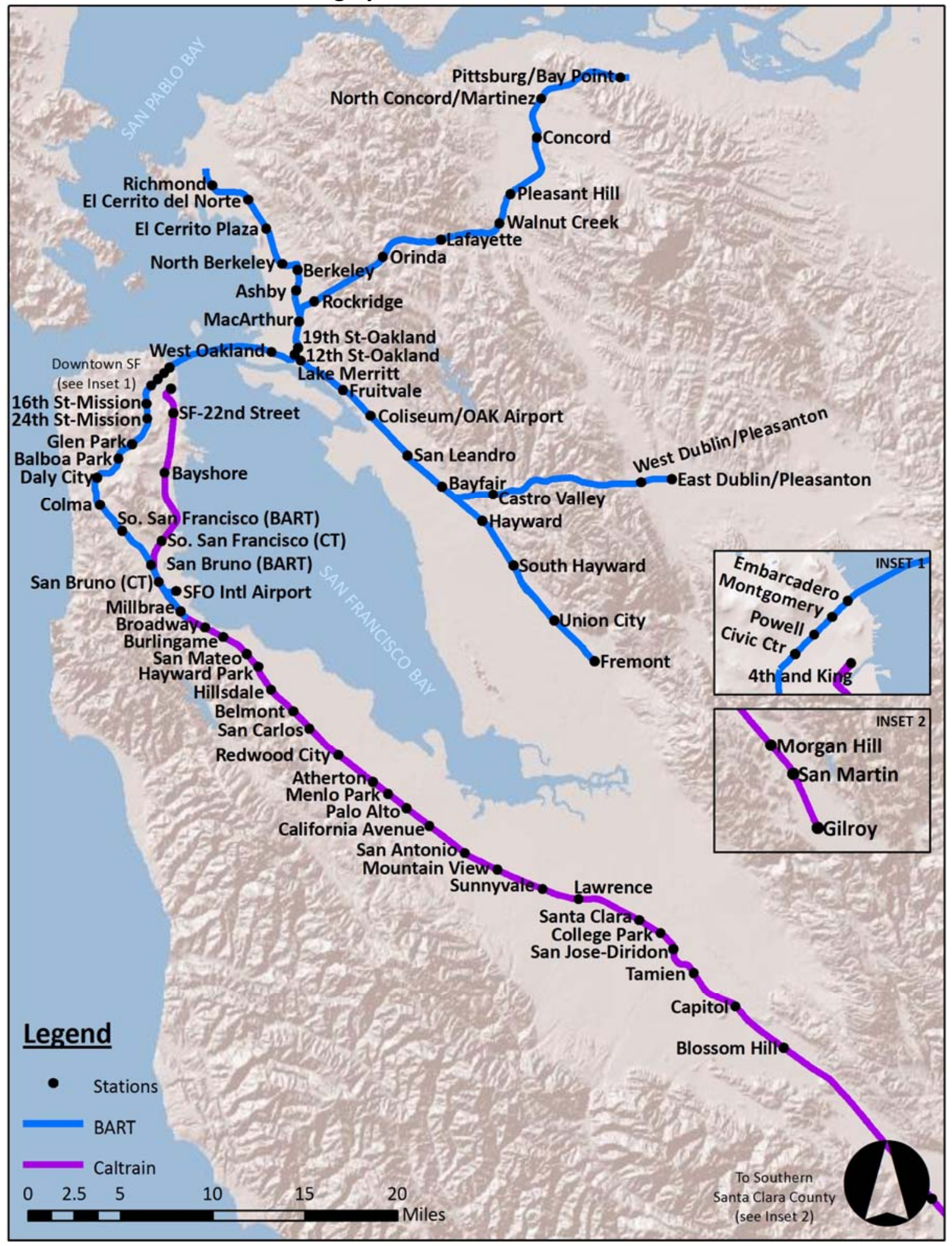

Source: SF-Metropolitan Transportation Commission, ESRI Shaded Relief Basemap 


\section{Figure 3.12}

\section{Alternative Network B: BART, Caltrain, eBART, BART-Silicon Valley, Caltrain-}

\section{Downtown SF}

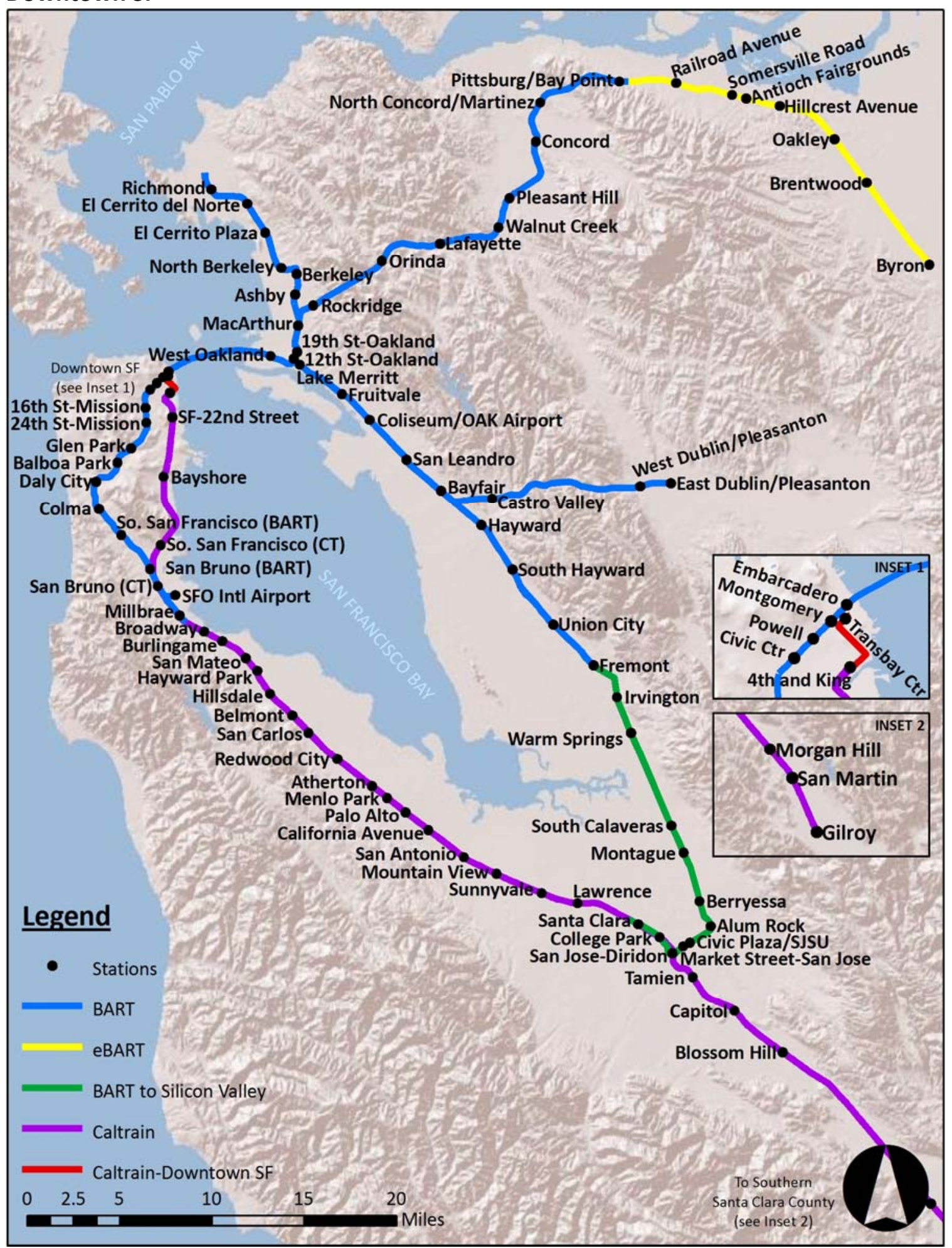

Source: SF-Metropolitan Transportation Commission, ESRI Shaded Relief Basemap 
Figure 3.13

Alternative Network C: Alternative B plus Dumbarton Rail

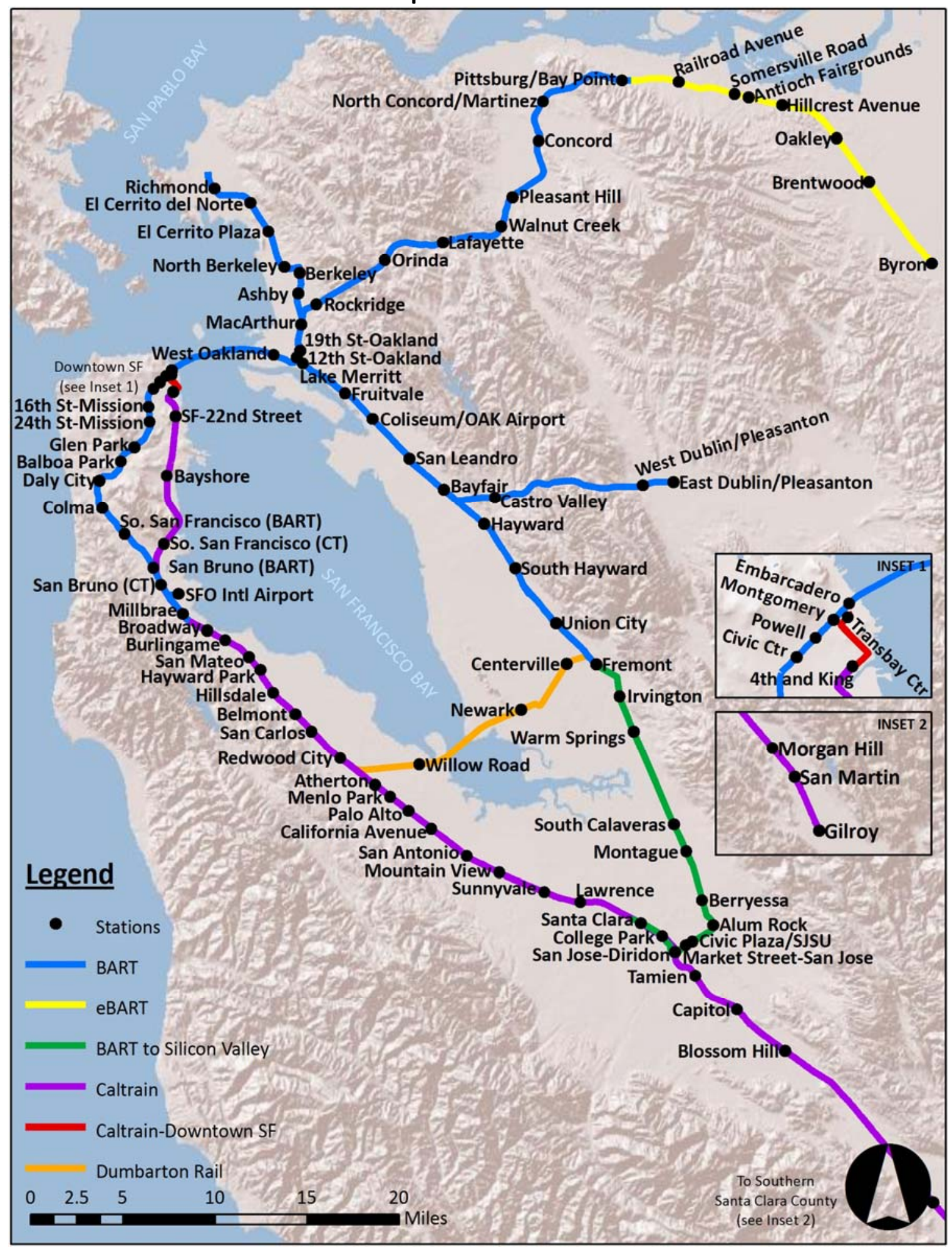

Source: SF-Metropolitan Transportation Commission, ESRI Shaded Relief Basemap 


\section{RESULTS AND ANALYSIS}

This chapter presents the results of the accessibility indices calculated for Bay Area rail transit stations included in this study. Since the accessibility indices are unitless values, it would make little sense to simply show the numbers. As a result, this chapter both states what the accessibility indices are, and discusses how different values relate to each other and change between the three alternative network configurations for which the indices are calculated. The three configurations combine existing and proposed lines to produce differing connectivity presented in Chapter 3 and summarized as follows (see Figure 4.1):

Alternative Configuration A considers the existing inter-city rail transportation network and looks at stations on the BART and Caltrain systems. Under existing conditions, the two systems form a trunk and branch shaped network.

Alternative Configuration B considers the existing system plus three extensions, the eBART extension, the BART to Silicon Valley extension, and the Caltrain to Downtown San Francisco extension. Considering these extensions, the network is in the shape of a loop going around the region with branches coming off at various points.

Alternative Configuration C considers every line from Alternative B plus the Dumbarton Rail line. With this addition, the network again consists of a loop around the region with branches, but also includes an additional mid-bay cross link connecting two sides of the loop. 


\section{Figure 4.1}

Schematic of Connectivity for the Three Alternative Network Configurations
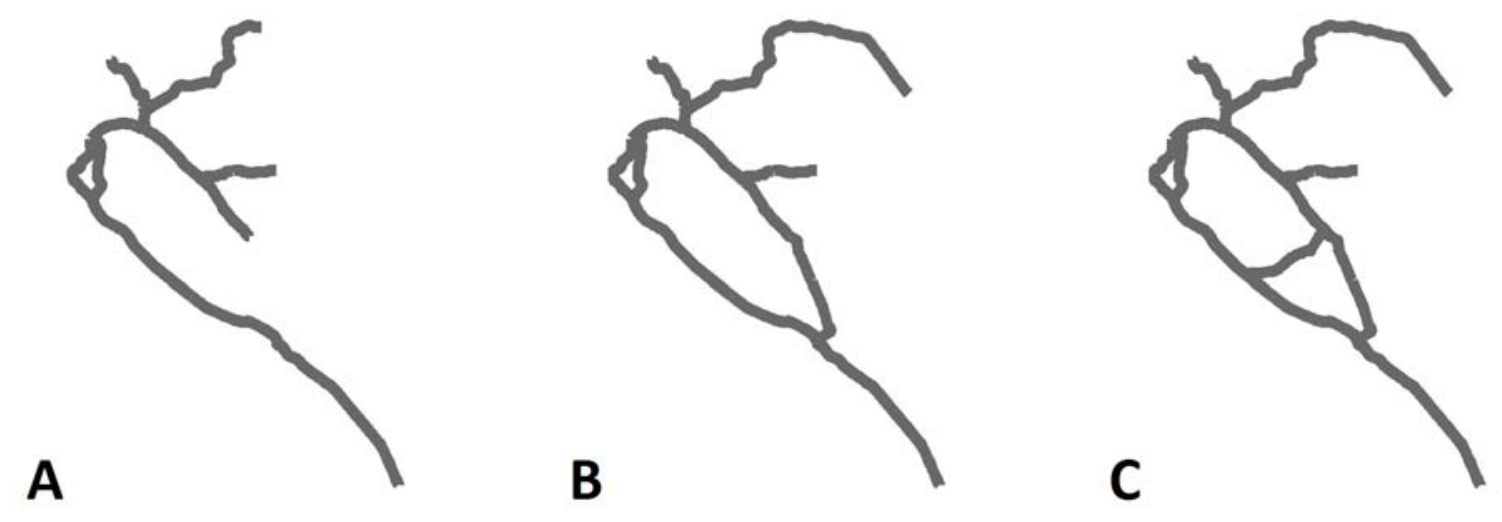

Accessibility indices were calculated for the three alternative network configurations but also calculated encompassing three different distances away from stations, one quarter mile, one half mile, and one mile. The results shown will be mainly those of the average of the three distances. Why the averages were selected is discussed in the later subsection on variation in accessibility indices by radii distances. Full data on accessibility index values for each of the three radii distances calculated are presented in the Appendix, Table X4.1, X4.2, and X4.3.

\subsection{Accessibility Indices}

\subsubsection{Accessibility Indices for Alternative Network Configuration A}

In Alternative Network Configuration A, accessibility indices are calculated assuming the existing intercity rail transportation network. For these existing stations, accessibility indices range from a low of .03 for the Gilroy Caltrain Station to a high of 78.48 for the Embarcadero BART Station. The mean accessibility index for stations under Alternative 
A is 7.68. Embarcadero Station is thus ten times higher than the system average and 4,426 times more accessible than the Gilroy Station.

Accessibility indices for stations under Alternative A are shown on a map in Figure 4.2 and in tabular form in the Appendix, Table X.1. Generally, the most accessible stations can be found in two of the three main regional centers, San Francisco and Oakland. Stations close to San Francisco and Oakland tended to be the next most accessible stations, with values tapering down with increasing distance away from the two cities.

There is some local fluctuation in the trend of tapering values as a result of job counts around other stations. In particular, there is also greater accessibility at stations in proximity to other regional satellite job centers. In the East Bay, relatively high accessibility index values are seen at stations close to the Berkeley and Walnut Creek Stations. In the peninsula, relatively high accessibility index values are seen near Redwood City.

Only a very small spike in accessibility index values can be seen in stations near downtown San Jose however. This is probably a result of Diridon Station, Caltrain’s downtown San Jose station, not being located directly in the main business area of Downtown, and thus not capturing much of downtown San Jose's employment. San Jose thus did not see the high index values in stations close to it that San Francisco and Oakland did, despite being the largest city of the three. 
While accessibility indices were higher at stations near job centers, they were not necessarily higher at the job centers themselves. Since this study is examining accessibility via inter-city rail travel, jobs at a given station were not counted toward its own accessibility index. Accessing jobs from one station area to the same station area would not necessitate a rail transit trip. More likely it would involve a pedestrian, bicycle, or local transit trip. Examples of this phenomenon can be seen in jobs-rich Berkeley and Walnut Creek which have lower accessibility index than adjacent North Berkeley and Ashby, and Pleasant Hill and Lafayette, which have fewer jobs. This phenomenon is not seen in Downtown San Francisco and Downtown Oakland as their main job centers are captured by multiple stations. Thus, while not counting jobs around their own station, stations could capture large amounts of other jobs, and in some cases, the same jobs from other nearby stations.

An interesting difference can also be seen comparing the main trunk of the Caltrain system through the peninsula with the BART Fremont Line in the East Bay, both of which run down developed corridors along the western and eastern shores respectively of San Francisco Bay. There are generally much higher indices along Caltrain, signaling a greater density of jobs near rail in the Peninsula than in the Lower, Coastal East Bay. 
Figure 4.2

Accessibility Indices - Alternative Network Configuration A

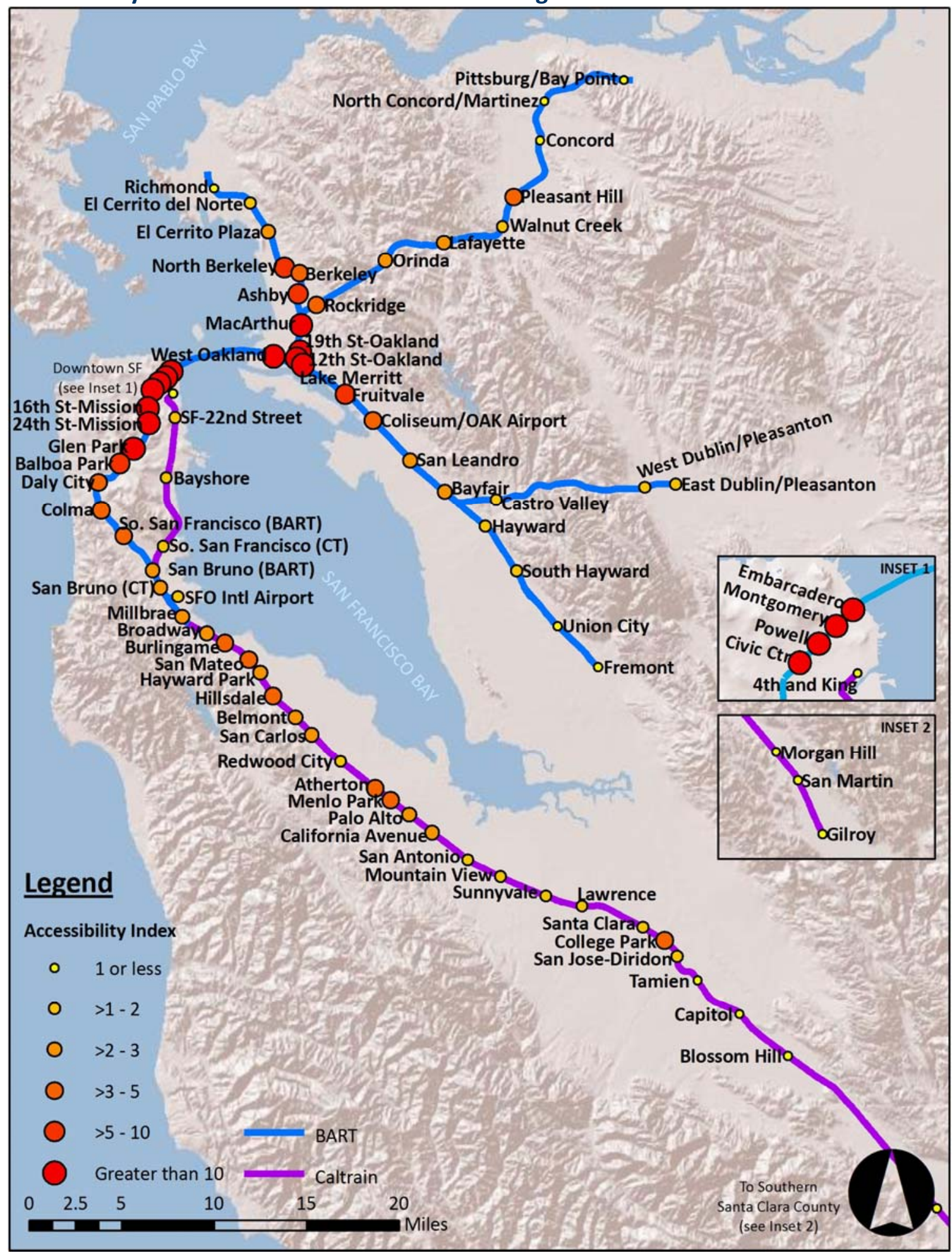

Source: SF-Metropolitan Transportation Commission, ESRI Shaded Relief Basemap 
A list of the 20 stations with the highest accessibility index and five stations with the lowest for Alternative A are shown below in Table 4.1.

Table 4.1

Top 20 and Bottom 5 Index Stations - Alternative Network Configuration A

\begin{tabular}{|c|c|c|c|c|}
\hline $\begin{array}{l}\text { Rank } \\
\text { (of 74) }\end{array}$ & Station & $\begin{array}{r}\text { Accessibility } \\
\text { Index }\end{array}$ & System & Location \\
\hline 1 & Embarcadero & 78.48 & BART & San Francisco \\
\hline 2 & Powell & 72.13 & BART & San Francisco \\
\hline 3 & Montgomery & 64.95 & BART & San Francisco \\
\hline 4 & Civic Center & 56.60 & BART & San Francisco \\
\hline 5 & 16th Street-Mission & 33.93 & BART & San Francisco \\
\hline 6 & 12th Street-Oakland & 24.56 & BART & Oakland \\
\hline 7 & 24th Street-Mission & 23.99 & BART & San Francisco \\
\hline 8 & 19th Street-Oakland & 22.32 & BART & Oakland \\
\hline 9 & Lake Merritt & 13.13 & BART & Oakland \\
\hline 10 & MacArthur & 12.37 & BART & Oakland \\
\hline 11 & West Oakland & 11.42 & BART & Oakland \\
\hline 12 & Glenn Park & 10.06 & BART & San Francisco \\
\hline 13 & North Berkeley & 8.93 & BART & Berkeley \\
\hline 14 & Ashby & 7.87 & BART & Berkeley \\
\hline 15 & Balboa Park & 6.27 & BART & San Francisco \\
\hline 16 & Fruitvale & 5.57 & BART & Oakland \\
\hline 17 & Berkeley & 4.93 & BART & Berkeley \\
\hline 18 & Menlo Park & 4.18 & Caltrain & Menlo Park \\
\hline 19 & Rockridge & 4.06 & BART & Oakland \\
\hline 20 & Coliseum/OAK Airport & 4.03 & BART & Oakland \\
\hline 70 & Fremont & 0.34 & BART & Fremont \\
\hline 71 & Blossom Hill & 0.22 & Caltrain & San Jose \\
\hline 72 & San Martin & 0.15 & Caltrain & San Martin \\
\hline 73 & Morgan Hill & 0.10 & Caltrain & Morgan Hill \\
\hline 74 & Gilroy & 0.03 & Caltrain & Gilroy \\
\hline
\end{tabular}

The stations that appear on the list reflect many of the observations that can be made by looking at the map of indices. Of the top 20, 16 are in San Francisco and Oakland. The highest ranked non-San Francisco and non-Oakland station is North Berkeley at $13^{\text {th }}$. 
At the bottom of the rankings are stations towards the ends of lines, and thus the furthest away from San Francisco and Oakland. Fremont, the terminus of the Fremont-Daly City BART line is ranked $70^{\text {th }}$ overall. The last four ranked stations are the four southernmost stations on Caltrain. Blossom Hill, the $71^{\text {st }}$ ranked station is actually in San Jose, which demonstrates the lack of accessibility generated on Caltrain from downtown San Jose. Blossom Hill, Morgan Hill $\left(73^{\text {rd }}\right)$, and Gilroy $\left(74^{\text {th }}\right)$ are ranked in descending order relative to their increasing distance to San Francisco. However, San Martin $\left(72^{\text {nd }}\right)$ is further than Morgan Hill but leapfrogs it as there are significantly more jobs in Morgan Hill than in San Martin.

\subsubsection{Accessibility Indices for Alternative Network Configuration B}

Alternative Network Configuration B incorporates the existing network and adds the eBART and Silicon Valley BART extensions, as well as the Caltrain to Downtown San Francisco extension. For this array of stations, accessibility indices range from a low of .04 in Gilroy to a high of 78.50 at Embarcadero. These are the same lowest and highest index stations as Alternative A. The mean accessibility index for stations under Alternative B is 7.44 .

Accessibility indices for stations under Alternative B are shown on a map in Figure 4.3 and in tabular form in the Appendix, Table X.2. As was seen in Alternative A, generally very high accessibility stations can be found in two of the three main regional centers, San Francisco and Oakland. However, unlike in Alternative A, very high accessibility stations can also be found in the third regional center, San Jose. The BART to Silicon 
Valley extension adds several stations to San Jose’s downtown core, capturing more jobs there, and raising accessibility indices in San Jose.

As in Alternative A, the next highest accessibility areas could be found in stations near the major cities, tapering down with distance. This is actually more noticeable near San Francisco in Alternative B. In Alternative A the characteristic of high accessibility near San Francisco was present on BART heading in both directions out of San Francisco, but not as much on Caltrain. The Downtown San Francisco Caltrain extension to the Transbay Center would provide access to many more jobs in San Francisco than can be reached at the current terminus of $4^{\text {th }}$ and King. Much like how BART to Silicon Valley raises accessibility indices in San Jose, this extension greatly increases the indices of stations at the northern end of Caltrain. 
Figure 4.3

Accessibility Indices - Alternative Network Configuration B

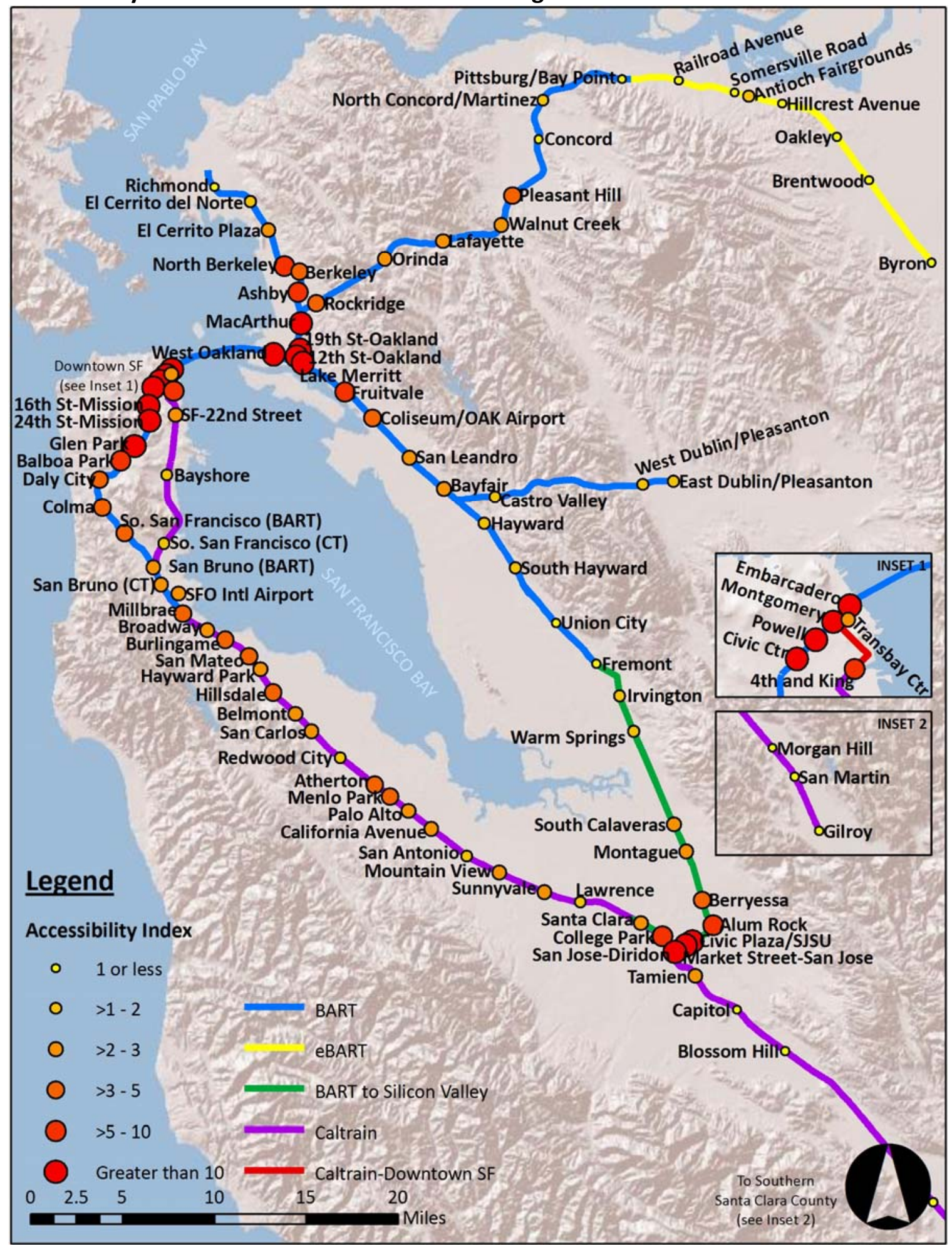

Source: SF-Metropolitan Transportation Commission, ESRI Shaded Relief Basemap 
A list of the 20 stations with the highest accessibility index and five stations with the lowest for Alternative B are shown below in Table 4.2.

Table 4.2

Top 20 and Bottom 5 Index Stations - Alternative Network Configuration B

\begin{tabular}{|c|c|c|c|c|}
\hline $\begin{array}{l}\text { Rank } \\
\text { (of 90) }\end{array}$ & Station & $\begin{array}{r}\text { Accessibility } \\
\text { Index }\end{array}$ & System & Location \\
\hline 1 & Embarcadero & 78.50 & BART & San Francisco \\
\hline 2 & Powell & 72.15 & BART & San Francisco \\
\hline 3 & Montgomery & 64.97 & BART & San Francisco \\
\hline 4 & Civic Center & 56.62 & BART & San Francisco \\
\hline 5 & 16th Street-Mission & 33.95 & BART & San Francisco \\
\hline 6 & 12th Street-Oakland & 24.57 & BART & Oakland \\
\hline 7 & 24th Street-Mission & 24.02 & BART & San Francisco \\
\hline 8 & 19th Street-Oakland & 22.33 & BART & Oakland \\
\hline 9 & Diridon & 20.30 & Caltrain/BART-SV & San Jose \\
\hline 10 & Civic Center/SJSU & 19.04 & BART-SJ & San Jose \\
\hline 11 & Market Street-San Jose & 16.23 & BART-SV & San Jose \\
\hline 12 & Lake Merritt & 13.14 & BART & Oakland \\
\hline 13 & MacArthur & 12.38 & BART & Oakland \\
\hline 14 & West Oakland & 11.44 & BART & Oakland \\
\hline 15 & Glenn Park & 10.10 & BART & San Francisco \\
\hline 16 & North Berkeley & 8.94 & BART & Berkeley \\
\hline 17 & 4th and King & 8.62 & Caltrain & San Francisco \\
\hline 18 & Ashby & 7.88 & BART & Berkeley \\
\hline 19 & Alum Rock & 7.19 & BART-SV & San Jose \\
\hline 20 & College Park & 6.65 & Caltrain & San Jose \\
\hline 86 & San Martin & 0.17 & Caltrain & San Martin \\
\hline 87 & Morgan Hill & 0.14 & Caltrain & Morgan Hill \\
\hline 88 & Brentwood & 0.12 & eBART & Brentwood \\
\hline 89 & Byron & 0.08 & eBART & Byron \\
\hline 90 & Gilroy & 0.04 & Caltrain & Gilroy \\
\hline
\end{tabular}

The addition of more stations in downtown San Jose vaults five San Jose stations into the top 20. 18 of the top 20 stations are in San Francisco, Oakland, or San Jose. Again, the top station outside the three major cities is North Berkeley at $16^{\text {th }}$. 
Gilroy $\left(90^{\text {th }}\right)$, San Martin $\left(86^{\text {th }}\right)$, and Morgan Hill $\left(87^{\text {th }}\right)$ remain among the bottom five stations as in Alternative A. Fremont, which is no longer a system terminus, and Blossom Hill, which benefits from the additional job access in San Jose, move out of the very bottom of the list. Brentwood $\left(88^{\text {th }}\right)$ and Byron $\left(89^{\text {th }}\right)$, the two easternmost stations along the eBART extension debut in the bottom five.

\subsubsection{Accessibility Indices for Alternative Network Configuration C}

Alternative Network Configuration C incorporates the existing network, the extensions analyzed in Alternative B, plus the proposed Dumbarton Rail project. Accessibility indices range from a low of .04 in Gilroy to a high of 78.50 at Embarcadero. These are the same lowest and highest index stations as Alternatives A and B, with both having the same lowest and highest value as in Alternative B. The mean accessibility index for stations under Alternative B is 7.24. Since the mean accessibility index drops from Alternative A to Alternative B to Alternative C, it can be said that the new stations added in each successive alternative are on average less accessible than the stations that existed in the previous alternatives.

Alternative C incorporates only three more stations than Alternative B and the distribution of accessibility index values is very similar to Alternative B. However, some stations do experience significant changes. This will be explored in more detail later in the accessibility increases by sub-regional geographic area subsection.

Accessibility indices for stations under Alternative $\mathrm{C}$ are shown on a map in Figure 4.4 and in tabular form in the Appendix, Table X4.3. 
Figure 4.4

Accessibility Indices - Alternative Network Configuration C

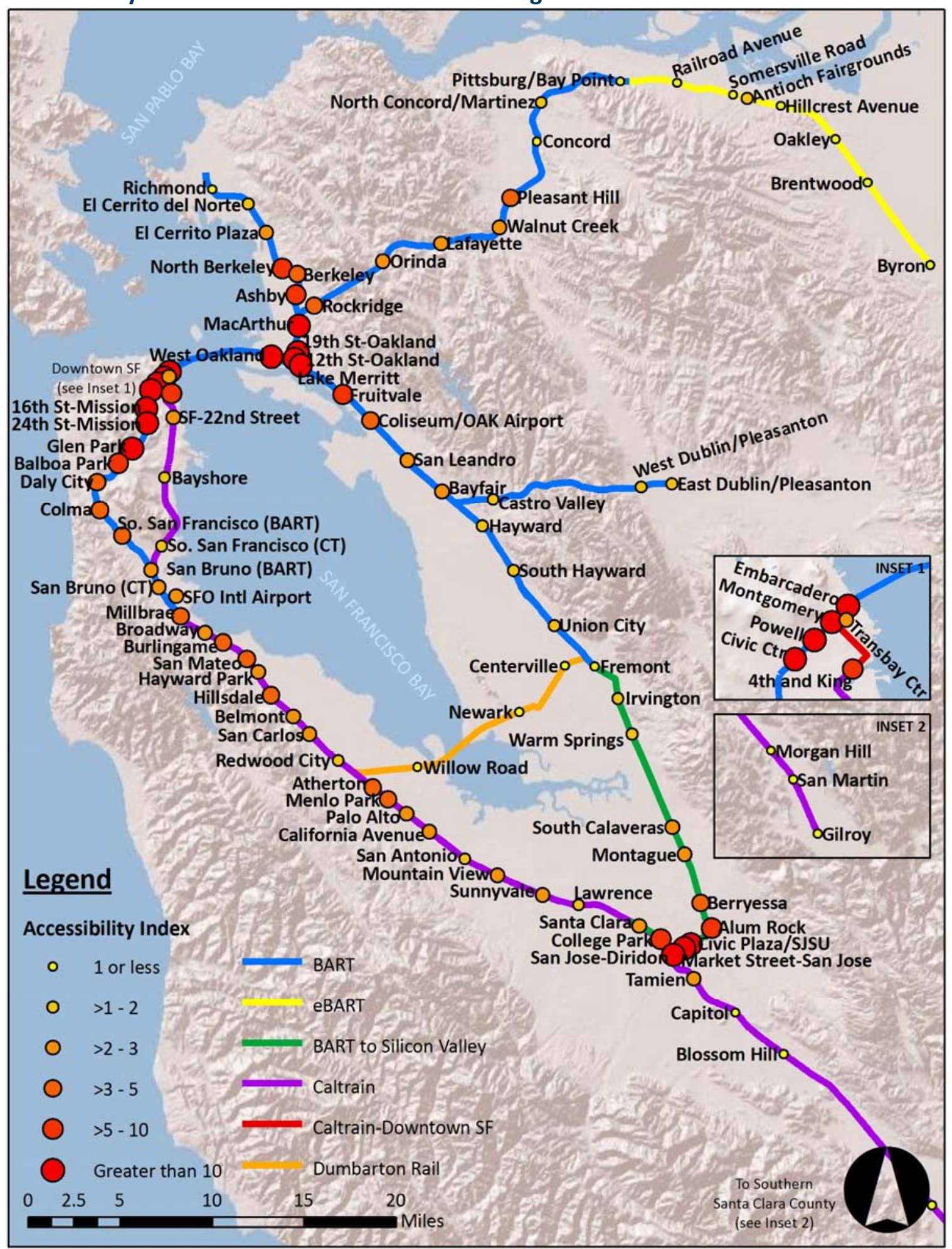

Source: SF-Metropolitan Transportation Commission, ESRI Shaded Relief Basemap 
A list of the 20 most and five least accessible stations for Alternative $\mathrm{C}$ is shown in Table 4.3. The top 20 and bottom five stations in Alternative $\mathrm{C}$ are identical to Alternative $\mathrm{B}$ with the same accessibility index values. All indices are marginally higher due to the increase in total jobs of the entire regional rail network from the three new stations.

Again, as will be shown later, Alternative C does produce noticeable impacts. However, it is not as apparent at the extremes, and more precisely, not as apparent in the geographic areas of the region where the top and bottom index stations are located.

\section{Table 4.3}

Top 20 and Bottom 5 Index Stations - Alternative Network Configuration C

\begin{tabular}{|c|c|c|c|c|}
\hline $\begin{array}{l}\text { Rank } \\
\text { (of 93) }\end{array}$ & Station & $\begin{array}{r}\text { Accessibility } \\
\text { Index }\end{array}$ & System & Location \\
\hline 1 & Embarcadero & 78.50 & BART & San Francisco \\
\hline 2 & Powell & 72.15 & BART & San Francisco \\
\hline 3 & Montgomery & 64.97 & BART & San Francisco \\
\hline 4 & Civic Center & 56.62 & BART & San Francisco \\
\hline 5 & 16th Street-Mission & 33.95 & BART & San Francisco \\
\hline 6 & 12th Street-Oakland & 24.57 & BART & Oakland \\
\hline 7 & 24th Street-Mission & 24.02 & BART & San Francisco \\
\hline 8 & 19th Street-Oakland & 22.34 & BART & Oakland \\
\hline 9 & Diridon & 20.32 & Caltrain/BART-SV & San Jose \\
\hline 10 & Civic Center/SJSU & 19.05 & BART-SV & San Jose \\
\hline 11 & Market Street-San Jose & 16.24 & BART-SV & San Jose \\
\hline 12 & Lake Merritt & 13.15 & BART & Oakland \\
\hline 13 & MacArthur & 12.38 & BART & Oakland \\
\hline 14 & West Oakland & 11.44 & BART & Oakland \\
\hline 15 & Glenn Park & 10.10 & BART & San Francisco \\
\hline 16 & North Berkeley & 8.94 & BART & Berkeley \\
\hline 17 & 4th and King & 8.63 & Caltrain & San Francisco \\
\hline 18 & Ashby & 7.88 & BART & Berkeley \\
\hline 19 & Alum Rock & 7.20 & Caltrain & San Jose \\
\hline 20 & College Park & 6.65 & Caltrain & San Jose \\
\hline 89 & San Martin & 0.33 & Caltrain & San Martin \\
\hline 90 & Morgan Hill & 0.29 & Caltrain & Morgan Hill \\
\hline 91 & Brentwood & 0.26 & eBART & Brentwood \\
\hline 92 & Byron & 0.16 & eBART & Byron \\
\hline 93 & Gilroy & 0.09 & Caltrain & Gilroy \\
\hline
\end{tabular}




\subsection{Variation in Accessibility Indices by Radii Distances}

As previously mentioned, the accessibility indices described above for the three Alternative Network Configurations are averages of the three indices calculated using different radii distances around stations (one quarter mile, one half mile, and one mile). This has been done for simplicity, as showing results for all three distances in the text would lead to a likely confusing discussion of up to nine different results for values and attributes. There is some variation between the index values from distance to distance, however when looking at all stations overall, the variation between radii distances is not significant.

To determine the significance of variation between the three radii distance, analysis of dispersion using Spearman’s Rho was conducted. With each increasing radius distance, it is expected by default that accessibility index values themselves would increase because of the capturing of more jobs. Thus, an analysis of variation using just the accessibility indices is not possible since they should be different. Instead, analysis of variation is done on accessibility ranks using Spearman’s Rho, since it is capable of handling ordinal level data like ranks.

Spearman's Rho values were calculated nine times. For each alternative network, Spearman's rho was calculated comparing index ranks at a quarter mile versus half mile, half mile versus one mile, and quarter mile versus one mile. The ranks of each station at each distance for each alternative can be found in the Appendix (see Appendix, Tables 
X4.4-X4.6). The resulting Spearman's Rho values vary from a low of .909 to a high of .974 (see Table 4.4).

Table 4.4

Spearman's Rho Values Measuring Variation of Accessibility Index Values between Radius Distances

\begin{tabular}{|c|c|c|c|c|}
\hline \multirow{2}{*}{ Alternative } & \multicolumn{3}{|c|}{ Spearman's Rho } & \multirow{2}{*}{ Average } \\
\cline { 2 - 4 } & $\begin{array}{c}\text { Quarter vs. } \\
\text { Half Mile }\end{array}$ & $\begin{array}{c}\text { Half vs. } \\
\text { One Mile }\end{array}$ & $\begin{array}{c}\text { Quarter vs. } \\
\text { One Mile }\end{array}$ & \\
\hline A & 0.963 & 0.964 & 0.909 & 0.945 \\
\hline B & 0.974 & 0.964 & 0.931 & 0.957 \\
\hline C & 0.973 & 0.968 & 0.935 & 0.959 \\
\hline Average & 0.970 & 0.966 & 0.925 & \\
\hline
\end{tabular}

Spearman's Rho values can range from a low of negative one to a high of positive one. A value of negative one signifies a full negative correlation between two sets of ranks, and a value of positive one signifies a full positive correlation. In a full positive correlation, the ranks are exactly the same between two sets, and in a full negative correlation, the ranks are exactly opposite. A value of zero signifies no correlation where ranks of the two sets are completely random to each other (Healey, 2005). All the values calculated in the case of this study are very close to positive one signaling a strong positive correlation.

The significance of the Spearman's Rho values can be evaluated by performing a tdistribution test. In the test, if the computed test statistic, t-obtained, based on Spearman's Rho, is beyond the identified baseline, t-critical value, the null hypothesis can be rejected that two sets of ranks analyzed are not related.

T-critical and t-obtained values based on Spearman's Rho are shown in Table 4.5. The tcritical values are based on a 95\% confidence interval, two tailed test, and vary for each alternative network due to the differing number of stations in each scenario. As can be 
clearly seen, the t-obtained values are well beyond the t-critical values. Thus, the null hypothesis can be rejected and it can be safely concluded that each set of rankings is sampling the same population of accessibility, up to a five percent chance of error. Full detail on this significance test is presented in the Appendix, Table X4.7.

Table 4.5

T-distribution Significance Test for Spearman's Rho Values

\begin{tabular}{|c|c|c|c|c|}
\hline \multirow{2}{*}{ Alternative } & $\begin{array}{c}\text { t-critical } \\
\text { (95\% confidence } \\
\text { interval) }\end{array}$ & $\begin{array}{c}\text { Quarter vs. } \\
\text { Half Mile }\end{array}$ & $\begin{array}{c}\text { Half vs. } \\
\text { One Mile }\end{array}$ & $\begin{array}{c}\text { Quarter vs. } \\
\text { One Mile }\end{array}$ \\
\cline { 3 - 5 } A & \pm 1.994 & 29.31 & 29.88 & 17.93 \\
\hline B & \pm 1.987 & 40.64 & 34.17 & 23.97 \\
\hline C & \pm 1.986 & 40.35 & 36.97 & 25.22 \\
\hline
\end{tabular}

While variation is proven not significant in Table 4.5, as shown in Table 4.4, the largest variation can be seen between index values calculated at one quarter mile versus one mile. All variation present can be traced back to the number of jobs counted around stations. The biggest fluctuations in rankings can be linked to two phenomenons regarding jobs. In the first phenomenon, a station has a given number of jobs around it. However they are concentrated in such a way that either most of the jobs do not show up at the shorter distances, or they mostly show up at the shorter distances, with few jobs being added at longer distances.

A quarter mile ring around a transit station encompasses .196 square miles, a one half mile ring encompasses .785 square miles, and a one mile ring encompasses 3.142 square miles. A one half mile ring is an area four times greater than a quarter mile ring, and a one mile rings is an area four times greater than a half mile ring. 
Accessibility would not sway much between distances if job counts around stations increased at the same pace area increases between distances. Of course, it would not be expected that most stations would actually follow this pattern of a given number of jobs at one quarter mile, four times as many jobs at one half mile, and four times as many jobs as that at one mile. With the presence of Euclidian zoning and the separation of land uses, it can not be expected that commercial zones, and thus employment, are heterogeneously dispersed in a given area. However, for some stations, the difference between job counts at different distances is far more or far less than a factor of four.

A prime example of this occurrence can be seen around the Dublin/Pleasanton stations, which are near the top of the list of most variable stations. At both stations, the number of jobs within a half mile radius is over 45 times greater than at a quarter mile radius, much greater than the theoretical 4:1 are to distance ratio (see Table 4.6).

Table 4.6

Variability In Job Counts Around East and West Dublin/Pleasanton Stations

\begin{tabular}{|c|c|c|}
\hline & $\begin{array}{r}\text { West Dublin/ } \\
\text { Pleasanton }\end{array}$ & $\begin{array}{r}\text { East Dublin/ } \\
\text { Pleasanton }\end{array}$ \\
\hline Jobs, $1 / 4$ Mile Radius & 225 & 70 \\
\hline Jobs, $1 / 2$ Mile Radius & 10,166 & 3,201 \\
\hline Jobs, 1 Mile Radius & 19,563 & 25,684 \\
\hline Ratio, $1 / 2$ Mile : $1 / 4$ Mile & 45.18 & 45.73 \\
\hline Ratio, 1 Mile : 1/2 Mile & 1.92 & 8.02 \\
\hline Ratio, 1 Mile : $1 / 4$ Mile & 86.95 & 366.91 \\
\hline
\end{tabular}

The second phenomenon involves stations that are nearby, but not directly in large job centers. Since they are not directly in the job centers, they have relatively low job counts at one quarter mile and one half mile. However, since they are nearby, at one mile they 
capture some of the large job centers’ jobs. If the job center is particularly large, like downtown San Francisco, this can be a very large difference in number of jobs.

$4^{\text {th }}$ and King Station in San Francisco has 3,250 within a one quarter mile radius (see Table 4.7). However, within one mile there are 98,363 jobs or 30.27 times as many. While definitely a high ratio compared to the $16: 1$ area to distance ratio, other stations have more extreme ratios. However, since $4^{\text {th }}$ and King is capturing an extremely large job center the difference in number of jobs is extremely high, 95,113 jobs. This large difference contributes into a large fluctuation in accessibility at the adjacent Transbay Center station, the highest variable station in Alternative Futures B and C.

Table 4.7

Variability In Job Counts Around $4^{\text {th }}$ and King Station

\begin{tabular}{|c|c|}
\hline & 4th and King \\
\hline Jobs, $1 / 4$ Mile Radius & 3,250 \\
\hline Jobs, $1 / 2$ Mile Radius & 18,574 \\
\hline Jobs, 1 Mile Radius & 98,363 \\
\hline Ratio, $1 / 2$ Mile : $1 / 4$ Mile & 5.72 \\
\hline Ratio, 1 Mile : $1 / 2$ Mile & 5.30 \\
\hline Ratio, 1 Mile : $1 / 4$ Mile & 30.27 \\
\hline Difference, $1 / 2$ Mile $-1 / 4$ Mile & 15,324 \\
\hline Difference, 1 Mile - $1 / 2$ Mile & 79,789 \\
\hline Difference, 1 Mile - $1 / 1 / 4$ Mile & 95,113 \\
\hline
\end{tabular}

An additional issue that comes up with the one mile radius is jobs within walking distance of a station being counted at another station. As previously mentioned, since this study is measuring transit-oriented accessibility, the jobs within walking distance of a station are not counted toward its own accessibility index. Stations that are very close together can have rings that overlap such that those jobs that are not counted as within 
walking distance are counted as accessible via transit from an adjacent station. This can be true for any of the three distances, but is particularly noticeable at the one mile radius.

It is completely plausible that given a choice of walking three quarters of a mile to a station, or taking a transit ride for one stop and walking one quarter of mile, a commuter may in fact take the transit ride. But, if more people choose the walk over the ride, the overlapping rings could make it so that we are over measuring the transit accessibility of a station by counting its pedestrian accessible jobs as transit accessible.

\subsection{Regional Impacts of Network Changes}

\subsubsection{Overall Increase To System}

All the stations in the region and all the jobs that the residents of the region can access from them provide a certain total level of accessibility to the region. This systemwide accessibility can be measured by summing the accessibility indices of all the stations. Extending the system, and in particular adding stations to the network, provides access to new jobs via transit that were previously not accessible on the system. As a result, the systemwide accessibility of the network increases.

The systemwide accessibility indices for the Bay Area rail transit network in each of the three alternative network configurations, and the rates of change of the systemwide index between the configurations, are shown in Table 4.8. 
Table 4.8

Systemwide Accessibility and Rates of Change From Alternatives A-C

\begin{tabular}{|l|r|r|r|r|}
\hline & $\begin{array}{r}\text { Quarter } \\
\text { Mile }\end{array}$ & Half Mile & Mile & Average \\
\hline Alternative Network A & 148.67 & 448.42 & $1,107.22$ & 568.10 \\
\hline Alternative Network B & 184.82 & 540.92 & $1,282.76$ & 669.50 \\
\hline Alternative Network C & 186.30 & 544.07 & $1,289.57$ & 673.31 \\
\hline $\begin{array}{l}\text { Percent Change In Sum Of } \\
\text { Accessibility Index, Alt. Network A-B }\end{array}$ & $24.3 \%$ & $20.6 \%$ & $15.9 \%$ & $17.8 \%$ \\
\hline $\begin{array}{l}\text { Percent Change In Sum Of } \\
\text { Accessibility Index, Alt. Network A-C }\end{array}$ & $25.3 \%$ & $21.3 \%$ & $16.5 \%$ & $18.5 \%$ \\
\hline $\begin{array}{l}\text { Percent Change In Sum Of } \\
\text { Accessibility Index, Alt. Network B-C }\end{array}$ & $0.8 \%$ & $0.6 \%$ & $0.5 \%$ & $0.6 \%$ \\
\hline
\end{tabular}

For the current network (Alternative A) the average systemwide accessibility index is 568.10. The systemwide index is 148.67 at a quarter mile, 448.42 at a half mile, and 1,107.22 at one mile. These expectedly increase with distance as counting jobs at greater distances encompass more jobs.

Alternative B adds 17 stations on three extensions and raises the average systemwide index 17.8 percent. Alternative $\mathrm{C}$ adds only three stations on the Dumbarton Rail extension. With comparatively fewer new stations, the systemwide index rises only .6 percent compared to Alternative C. Comparing back to Alternative Future A, the 20 stations added between Alternatives A and C result in an increase of 18.5 percent.

Notably, the increases between scenarios increase with decreasing distance from stations. This indicates that generally around the stations added to the system in Alternatives B and $\mathrm{C}$, the jobs closer to the station are denser than those further away. This is a good development for potential commuters who may not be willing to walk as far from a station to reach a job. 


\subsubsection{Impacts on Accessibility by Sub-Regional Area Type}

When looking at the amount of accessibility gained from extensions to the rail network, it may be important to consider where in the region, and in what types of areas in the region, these accessibility gains are taking place.

For example, there is the issue of densities required in an area for there to be enough travelers to utilize transit. A study by Messenger and Ewing, 1996, found that it takes densities of 8.4 dwelling units or greater to support moderate 25 minute headways for bus service. At this density, the transit operator is running at the lowest level of productivity sustainable. For the operator to run at an average level of productivity, more than double the density, 19.4 dwelling units per acre are required (Messenger and Ewing, 1996). This is subject to local fluctuation. Rail systems typically have higher passenger capacities and operating costs than bus systems, so conceivably higher densities than this will be required than rail.

Sub-regional area type plays into the issue of density as different types of areas have differing density. Generally, central cities have greater densities than suburbs. Even among suburbs there are density differences, with older, inner-ring suburbs that developed in the Streetcar Era of transportation, or early Freeway era being denser than, newer, outer-ring suburbs that have developed in more recent decades.

To look at what types of areas in the region accessibility gains are concentrated, the stations and proposed stations in the network have been broken down into four sub- 
regional area types. These types are Central City - Central Business District areas, Central City - Non-CBD areas, Inner Ring Suburbs, and Outer Ring Suburbs.

Defining these sub-regional types can be fairly subjective, with geographic location, and era in which a community was developed being factors, among others. For the purposes of this analysis, the central cities are defined to be the three main regional centers, San Francisco, San Jose, and Oakland. Stations in the downtowns are the Central Business District area stations, and stations in all other areas are the Non-CBD area stations.

Inner ring suburb stations are defined as those not in the three main regional centers, but inside the valley in which San Francisco Bay sits. The valley in which the bay sits is surrounded for the most part by hillsides. Stations in the bay valley, or before the hillsides, form a ring directly around the Bay.

Outer ring suburb stations are defined as those not in the three main regional centers, and outside the valley in which San Francisco Bay directly sits. These stations are either in the hills that frame the bay valley, or in successive valleys and hillsides

Summing the accessibility index increases of each sub-regional area type between the three alternative future scenarios shows that almost all of the systemwide growth between the scenarios is in three of the four area types, Central City - CBD, Central City - NonCBD, and Inner Ring Suburbs, and a relatively small share of growth in Outer Ring Suburbs (see Table 4.9). 
Table 4.9

Shares of Growth In Accessibility Between Alternative Network Configurations by SubRegional Area Type

\begin{tabular}{|l|r|r|r|r|r|}
\hline \multirow{2}{*}{} & \multicolumn{4}{|c|}{ Sub-Regional Area Type } \\
\cline { 2 - 6 } & $\begin{array}{r}\text { Central } \\
\text { City } \\
\text { CBD }\end{array}$ & $\begin{array}{r}\text { Central } \\
\text { City } \\
\text { Non-CBD }\end{array}$ & $\begin{array}{r}\text { Inner } \\
\text { Ring } \\
\text { Suburbs }\end{array}$ & $\begin{array}{r}\text { Outer } \\
\text { Ring } \\
\text { Suburbs }\end{array}$ & $\begin{array}{r}\text { All } \\
\text { Stations }\end{array}$ \\
\hline Total Index, Alternative A & 319.04 & 133.57 & 99.57 & 15.93 & 568.10 \\
\hline Total Index, Alternative B & 357.03 & 166.72 & 125.81 & 19.94 & 669.50 \\
\hline Total Index, Alternative C & 357.06 & 166.79 & 129.49 & 19.97 & 673.31 \\
\hline $\begin{array}{l}\text { Share of Growth of Sum Accessibility } \\
\text { Index, Alternative A-B }\end{array}$ & $37.5 \%$ & $32.7 \%$ & $25.9 \%$ & $4.0 \%$ & $100.0 \%$ \\
\hline $\begin{array}{l}\text { Share of Growth of Sum Accessibility } \\
\text { Index, Alternative A-C }\end{array}$ & $36.1 \%$ & $31.6 \%$ & $28.4 \%$ & $3.8 \%$ & $100.0 \%$ \\
\hline $\begin{array}{l}\text { Share of Growth of Sum Accessibility } \\
\text { Index, Alternative B-C }\end{array}$ & $0.9 \%$ & $2.0 \%$ & $96.4 \%$ & $0.7 \%$ & $100.0 \%$ \\
\hline
\end{tabular}

Comparing Alternatives A and B, the largest share of growth in accessibility is held by Central City - CBD stations at just over one third. Central City - Non-CBD stations hold slightly less than one third and Inner Ring Suburbs hold just over one quarter of accessibility growth. Outer ring suburbs hold only four percent of accessibility growth.

The shares of growth are similar when comparing Alternatives A and C, which again, as previously mentioned makes sense as Alternative $\mathrm{C}$ accounts for only one new line. Compared to changes from Alternative A to B, Central City - CBD, Central City - NonCBD, and Outer Ring Suburbs have slightly smaller shares of growth and Inner Ring Suburbs have a slightly higher share of growth. This is not surprising as almost all of the growth from Alternative B and C, 96.4 percent, is in Inner Ring Suburbs. Dumbarton Rail connects stations and adds stations to inner-ring suburbs only.

The classification of stations to the four sub-regional area types is shown in Figure 4.5. 


\section{Figure 4.5}

\section{Stations by Sub-Regional Area Type}

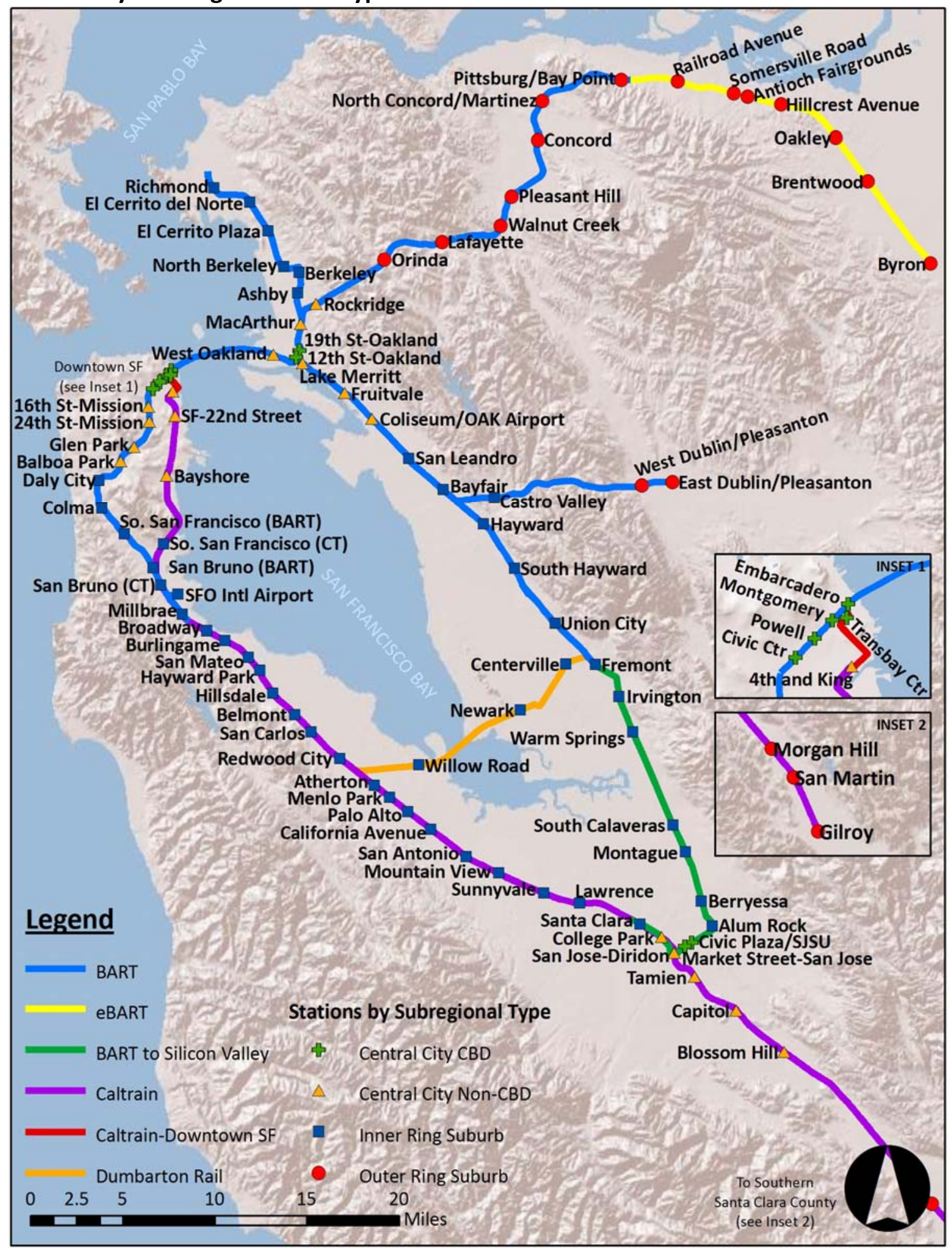

Source: SF-Metropolitan Transportation Commission, ESRI Shaded Relief Basemap 


\subsubsection{Impacts on Accessibility by Sub-Regional Geographic Area}

Just as the extensions in the different alternative future scenarios impact accessibility in different sub-regional area types to varying degrees, accessibility gains vary in different areas of the Bay Area geographically. Expectedly, the biggest increases come in stations that are adjacent to extensions. However, the magnitude of these increases and the extent to which increases are seen as distance increases from extensions varies in the alternatives.

For descriptive purposes, the region is split up into six regional subareas. These subareas are the Upper Peninsula, Lower Peninsula, South Bay, Coastal East Bay (Upper), Coastal East Bay (Lower), and Inland East Bay. From Alternative A to B, and Alternative A to C, a majority of the total systemwide accessibility growth occurs in the South Bay. A majority of growth from Alternative B to C occur in the Lower, Coastal East Bay, with another more than one third in the Lower Peninsula (see Table 4.10). How individual stations increase in accessibility in these areas is discussed in more detail in the following subsections. 
Table 4.10

Shares of Growth In Accessibility Between Alternative Network Configurations by SubRegional Geographic Area

\begin{tabular}{|c|c|c|c|c|c|c|c|}
\hline & \multicolumn{6}{|c|}{ Sub-Regional Geographic Area } & \multirow[b]{2}{*}{$\begin{array}{r}\text { All } \\
\text { Stations }\end{array}$} \\
\hline & $\begin{array}{r}\text { Upper } \\
\text { Peninsula }\end{array}$ & $\begin{array}{r}\text { Lower } \\
\text { Peninsula }\end{array}$ & $\begin{array}{l}\text { Coastal } \\
\text { East Bay } \\
\text { (Upper) }\end{array}$ & $\begin{array}{r}\text { Coastal } \\
\text { East Bay } \\
\text { (Lower) }\end{array}$ & $\begin{array}{r}\text { Inland } \\
\text { East } \\
\text { Bay }\end{array}$ & $\begin{array}{r}\text { South } \\
\text { Bay }\end{array}$ & \\
\hline $\begin{array}{l}\text { Total Index, } \\
\text { Alternative A }\end{array}$ & 369.25 & 34.09 & 124.47 & 9.42 & 15.66 & 15.21 & 568.10 \\
\hline $\begin{array}{l}\text { Total Index, } \\
\text { Alternative B }\end{array}$ & 385.26 & 51.56 & 124.62 & 13.23 & 19.58 & 75.25 & 669.50 \\
\hline $\begin{array}{l}\text { Total Index, } \\
\text { Alternative C }\end{array}$ & 385.40 & 52.92 & 124.67 & 15.37 & 19.61 & 75.35 & 673.31 \\
\hline $\begin{array}{l}\text { Share of Growth } \\
\text { of Sum Access. } \\
\text { Index, Alt. A-B }\end{array}$ & $15.79 \%$ & $17.22 \%$ & $0.15 \%$ & $3.75 \%$ & $3.87 \%$ & $59.21 \%$ & $100 \%$ \\
\hline $\begin{array}{l}\text { Share of Growth } \\
\text { of Sum Access. } \\
\text { Index, Alt. A-C }\end{array}$ & $15.35 \%$ & $17.90 \%$ & $0.19 \%$ & $5.65 \%$ & $3.76 \%$ & $57.16 \%$ & $100 \%$ \\
\hline $\begin{array}{l}\text { Share of Growth } \\
\text { of Sum Access. } \\
\text { Index, Alt. B-C }\end{array}$ & $3.67 \%$ & $35.84 \%$ & $1.27 \%$ & $56.03 \%$ & $0.65 \%$ & $2.53 \%$ & $100 \%$ \\
\hline
\end{tabular}

A map showing the division of the region into the six subareas is shown in Figure 4.6. 
Figure 4.6

Sub-Regional Geographic Areas

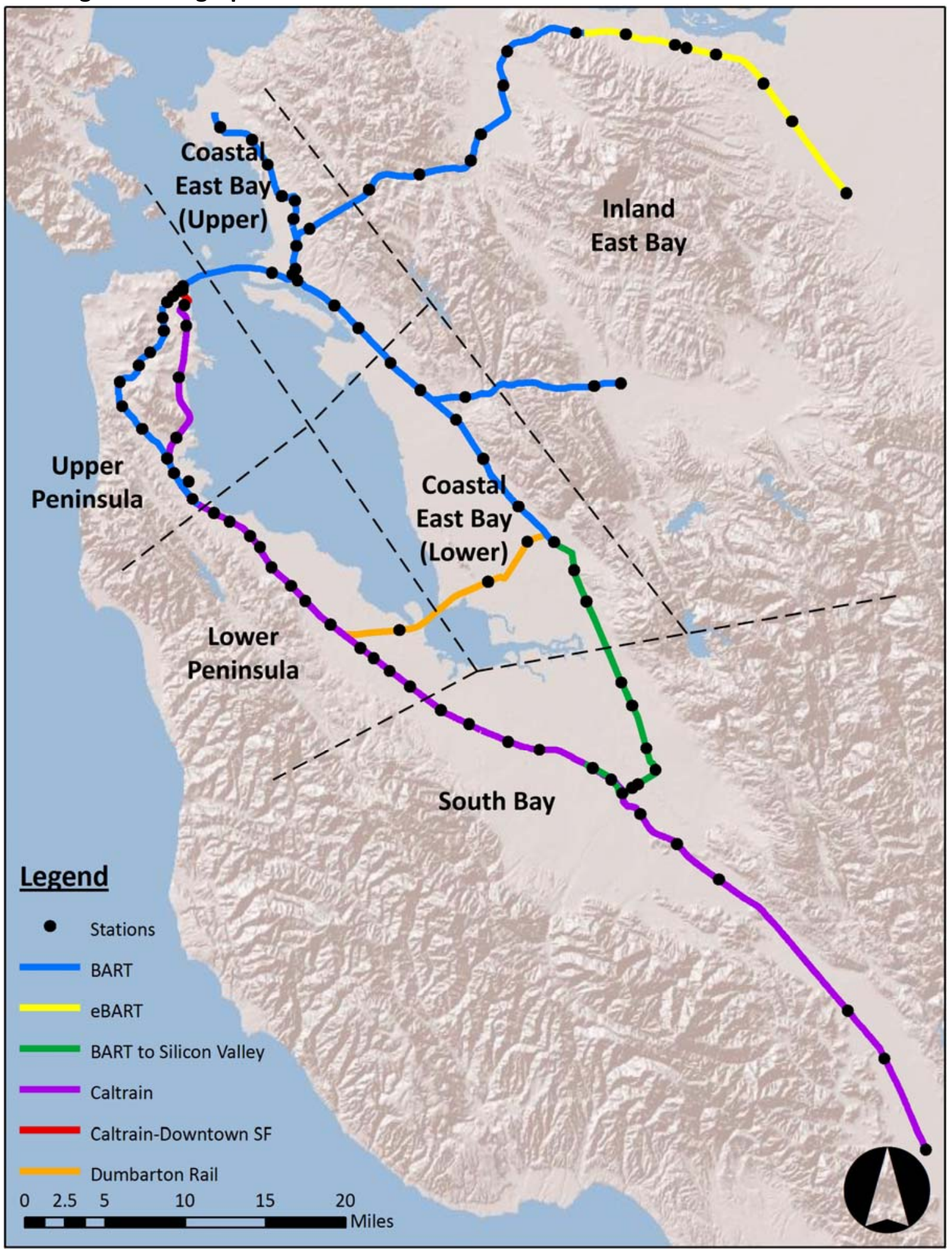

Source: SF-Metropolitan Transportation Commission, ESRI Shaded Relief Basemap 


\subsection{3a. Increases from Alternative Network Configurations $A$ to $B$}

From Alternative A to B, new lines and extensions extend from or connect to existing lines in the Upper Peninsula, South Bay, Coastal East Bay (Lower), and Inland East Bay subareas. Each subarea thus contains at least one station that shows relatively high growth in accessibility indices. In the Upper Peninsula, the northernmost six stations of the existing Caltrain line adjacent to the Downtown San Francisco extension all increase by more than 10 percent. In the South Bay, 13 stations have their indices increase by more than 10 percent in proximity to the BART to Silicon Valley extension. All 13 of these stations are on Caltrain.

While the BART to Silicon Valley spurs high increases in the South Bay, on the San Jose end of the extension, such high increases are not seen as much on the other end of the extension in the lower, Coastal East Bay. Here, only the two southernmost stations of the Fremont BART line increase by more than 10 percent. Similar unspectacular growth can be seen in the Inland East Bay adjacent to the eBART extension where only the terminal Pittsburg station has an index that grows by more than 10 percent.

Overall, from Alternative A to B, 22 stations have indices that increase by more than 10 percent. The most dramatic increases in indices can be seen at $4^{\text {th }}$ and King Station, which increases over 1,700 percent, and Diridon Station, which increases over 1,000

percent. Tamien, SF-22 ${ }^{\text {nd }}$ Street, and Fremont increase over 100 percent. 
On the opposite extreme, 30 stations have indices that increase by less than one percent. This indicates that travel times are too long, and thus level of impedance of travel too high, for the new jobs accessible around stations on the new lines to make a large impact on those stations. The 15 stations that show the greatest increase in accessibility are shown below in Table 4.11.

Table 4.11

Top 10 Increases in Accessibility for Stations from Alternative A to B

\begin{tabular}{|c|c|c|r|}
\hline Rank & Station & Regional Subarea & $\begin{array}{r}\text { Average Rate of } \\
\text { Increase }\end{array}$ \\
\hline 1 & 4th and King & Upper Peninsula & $1752.5 \%$ \\
\hline 2 & Diridon & South Bay & $1056.9 \%$ \\
\hline 3 & Tamien & South Bay & $126.0 \%$ \\
\hline 4 & SF-22nd St & Upper Peninsula & $124.5 \%$ \\
\hline 5 & Fremont & Coastal East Bay (Lower) & $122.4 \%$ \\
\hline 6 & Blossom Hill & South Bay & $82.9 \%$ \\
\hline 7 & College Park & South Bay & $80.6 \%$ \\
\hline 8 & Capitol & South Bay & $79.9 \%$ \\
\hline 9 & SFO Intl Airport & Upper Peninsula & $77.7 \%$ \\
\hline 10 & Santa Clara & South Bay & $68.0 \%$ \\
\hline
\end{tabular}

A map depicting increases systemwide from Alternative A to B can be seen in Figure 4.7 with full data on increases for all stations in the Appendix, Table X4.8. 


\section{Figure 4.7}

Increases in Accessibility for Stations from Alternative A to B

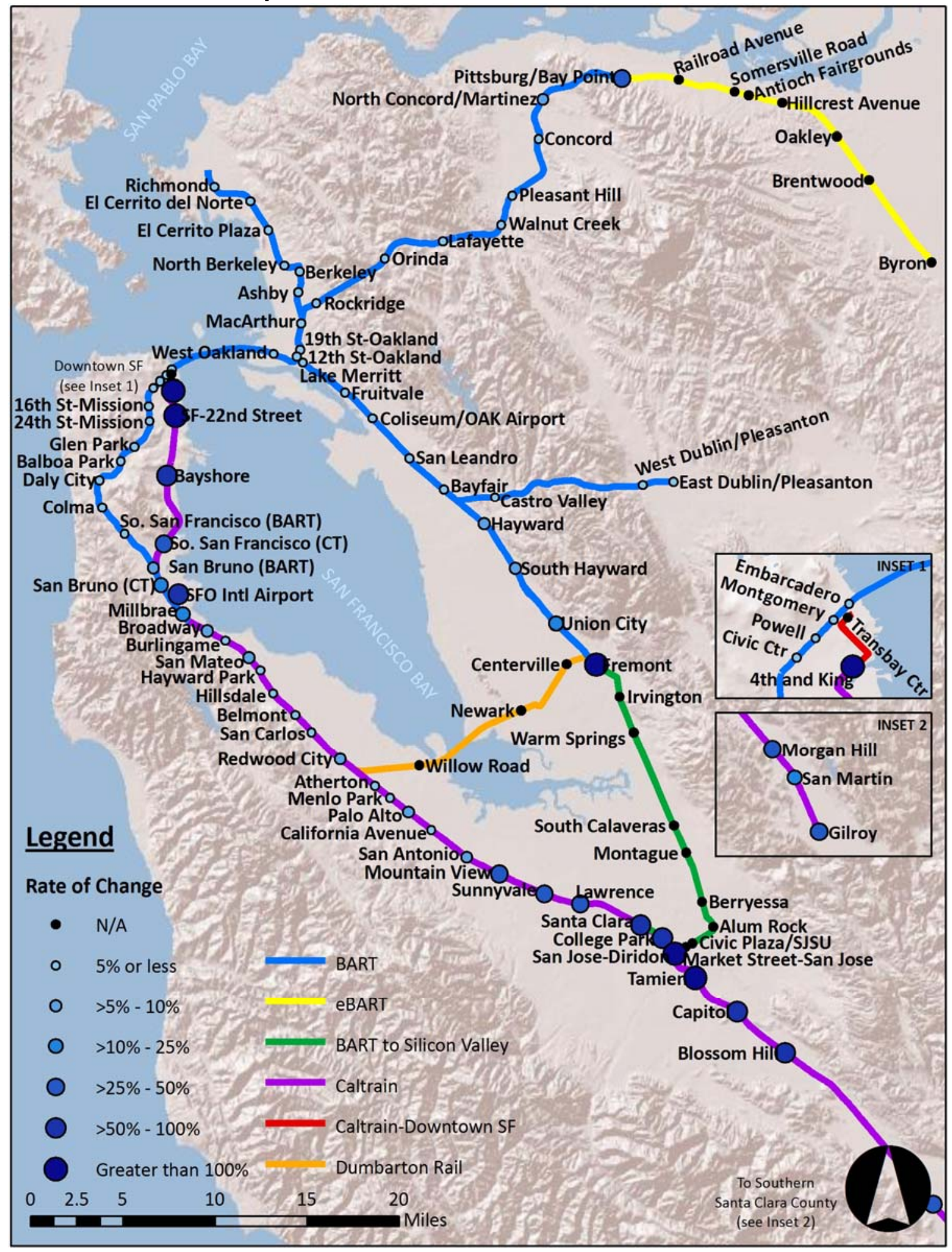

Source: SF-Metropolitan Transportation Commission, ESRI Shaded Relief Basemap 


\subsection{3b. Increases from Alternative Network Configurations $A$ to $C$}

Increases from Alternative $\mathrm{A}$ to $\mathrm{C}$ are very similar to the increases from Alternative $\mathrm{A}$ to B. Again, the highest increases can be seen in stations adjacent to new lines.

Similar to the change from Alternative A to B, the highest increases can be seen in the Upper Peninsula in proximity to the Caltrain-Downtown San Francisco extension, in the South Bay, near the Downtown San Jose end of the BART to Silicon Valley extension, in the Lower, Coastal East Bay near the Fremont end of the BART to Silicon Valley extension, and in the Inland East Bay at the Pittsburg end of the eBART extension.

Additional relatively high increases can be seen from Alternative A to C in the Lower Peninsula, and Lower, Coastal East Bay, on the two ends of the Dumbarton Rail line. Compared to the increases near the other extensions, these higher increases less dramatic as is the case with eBART. Alternative Future A to C has only one additional station experiencing greater than a 10 percent increase in accessibility compared to Alternative Future A to B.

Overall, from Alternative A to C, 23 stations have indices that increase by more than 10 percent, and 29 stations have indices that increase by only one percent or less. The 10 stations with the greatest increases are the same as from Alternative A to B, however Fremont moves from fifth highest increase to third highest increase, with Tamien, and SF-22 ${ }^{\text {nd }}$ Street sliding down one position accordingly (see Table 4.12). 
Table 4.12

Top 10 Increases in Accessibility for Stations from Alternative A to C

\begin{tabular}{|c|c|c|r|}
\hline Rank & Station & Regional Subarea & $\begin{array}{r}\text { Average Rate of } \\
\text { Increase }\end{array}$ \\
\hline 1 & 4th and King & Upper Peninsula & $1753.2 \%$ \\
\hline 2 & Diridon & South Bay & $1057.8 \%$ \\
\hline 3 & Fremont & Coastal East Bay (Lower) & $149.5 \%$ \\
\hline 4 & Tamien & South Bay & $126.1 \%$ \\
\hline 5 & 22 nd St & Upper Peninsula & $124.7 \%$ \\
\hline 6 & Blossom Hill & South Bay & $83.7 \%$ \\
\hline 7 & College Park & South Bay & $80.6 \%$ \\
\hline 8 & Capitol & South Bay & $80.5 \%$ \\
\hline 9 & SFO Intl Airport & Upper Peninsula & $79.2 \%$ \\
\hline 10 & Santa Clara & South Bay & $68.1 \%$ \\
\hline
\end{tabular}

The average increases for all stations go up compared to the change from Alternative A to B as all stations have access to the additional jobs not counted in Alternative B. A map depicting increases systemwide from Alternative A to C can be seen in Figure 4.8 with full data on increases for all stations in the Appendix, Table X4.9. 
Figure 4.8

Increases in Accessibility for Stations from Alternative A to C

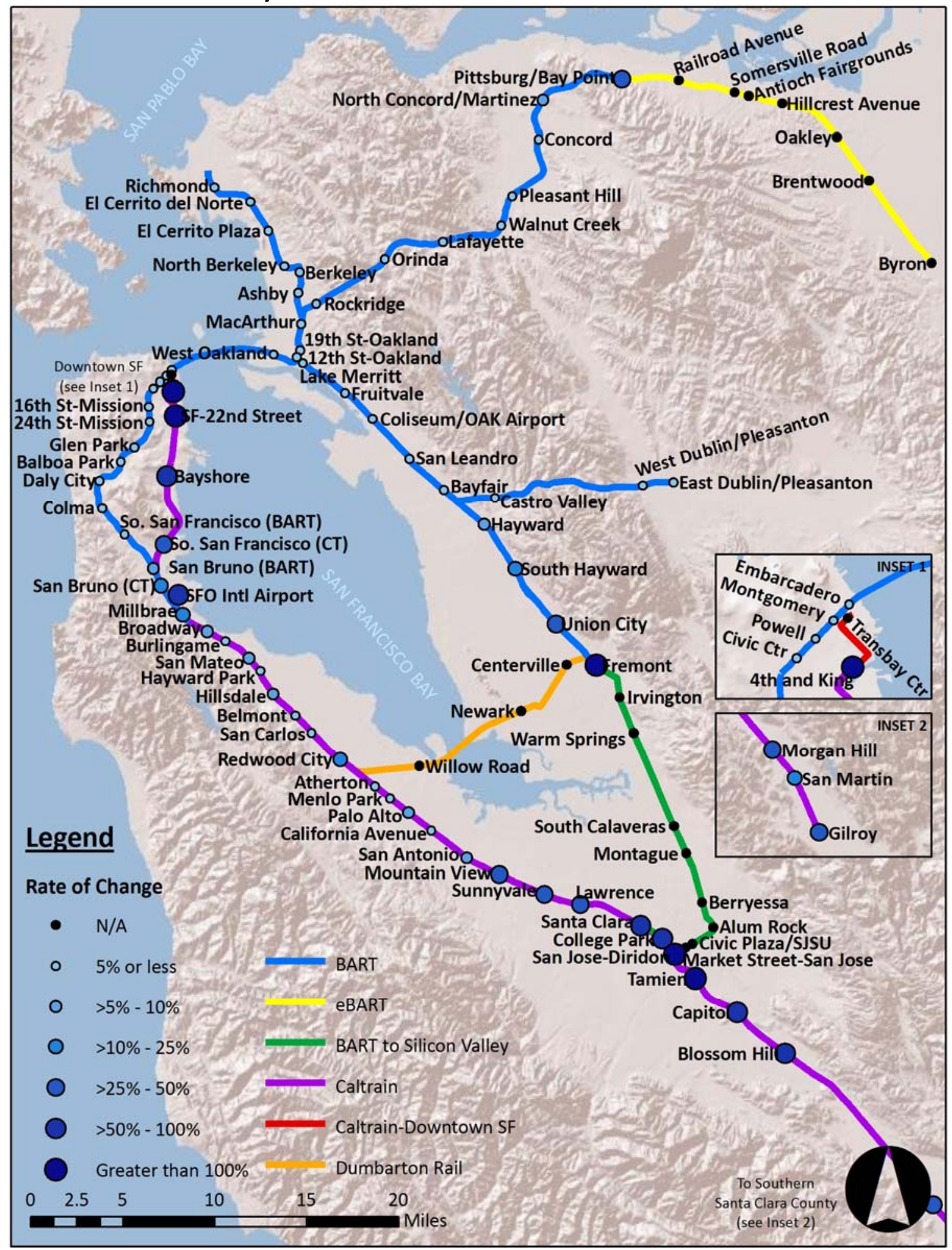

Source: SF-Metropolitan Transportation Commission, ESRI Shaded Relief Basemap 


\subsection{3c. Increases from Alternative Network Configurations B to $C$}

Looking at just the increases from Alternative B to C, we can isolate the specific impact in accessibility as a result of only the Dumbarton Rail line. Since it connects the Lower Peninsula and Lower, Coastal East Bay, relatively high increases can be seen in these geographic areas. Relatively low increases can be seen in the other four geographic areas.

From Alternative B to C, only 14 stations have increases greater than 1 percent, all in the Lower Peninsula, and Lower, Coastal East Bay. Comparing the two subareas, Lower, Coastal East Bay stations register increases higher than Lower Peninsula stations. This reflects the higher number of jobs in the Lower Peninsula that stations in the Lower, Coastal East Bay can access. Lower, Coastal East Bay stations are the top three and four of the top five stations with greatest increases in accessibility (see Table 4.13). Union City shows the greatest rate of increase at just under 20 percent.

Table 4.13

Top 10 Increases in Accessibility for Stations from Alternative B to C

\begin{tabular}{|c|c|c|r|}
\hline Rank & Station & Regional Subarea & $\begin{array}{r}\text { Average Rate of } \\
\text { Increase }\end{array}$ \\
\hline 1 & Union City & Coastal East Bay (Lower) & $19.7 \%$ \\
\hline 2 & Fremont & Coastal East Bay (Lower) & $12.2 \%$ \\
\hline 3 & South Hayward & Coastal East Bay (Lower) & $7.7 \%$ \\
\hline 4 & Redwood City & Lower Peninsula & $6.2 \%$ \\
\hline 5 & Hayward & Coastal East Bay (Lower) & $4.3 \%$ \\
\hline 6 & San Carlos & Lower Peninsula & $3.3 \%$ \\
\hline 7 & Irvington & Coastal East Bay (Lower) & $2.6 \%$ \\
\hline 8 & Warm Springs & Coastal East Bay (Lower) & $2.5 \%$ \\
\hline 9 & Atherton & Lower Peninsula & $2.2 \%$ \\
\hline 10 & Belmont & Lower Peninsula & $1.9 \%$ \\
\hline
\end{tabular}

A map depicting increases systemwide from Alternative B to C can be seen in Figure 4.9 with full data on increases for all stations in the Appendix, Table X4.10. 
Figure 4.9

Increases in Accessibility for Stations from Alternative B to C

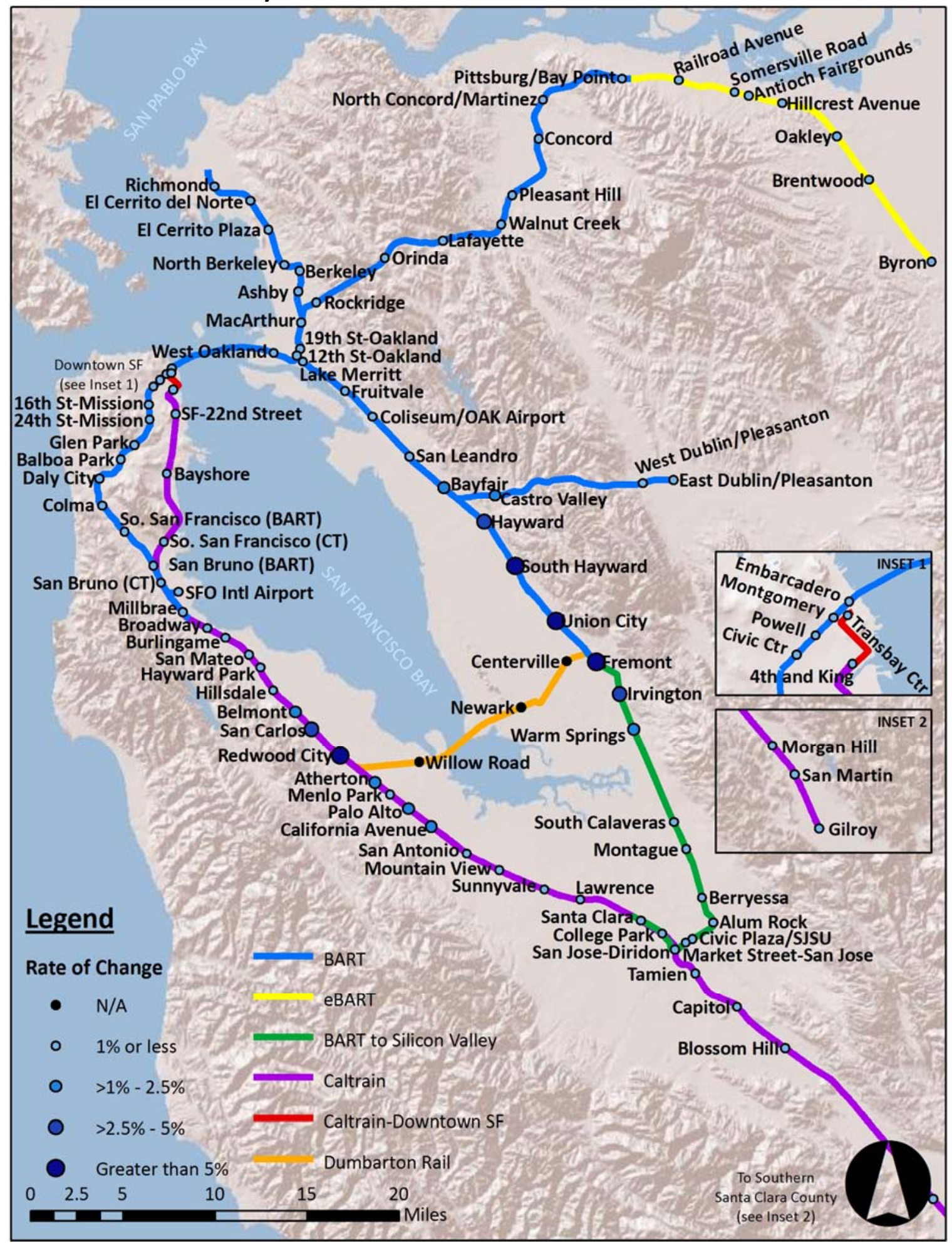

Source: SF-Metropolitan Transportation Commission, ESRI Shaded Relief Basemap 


\subsection{Accessibility of New Lines and Extensions}

\subsubsection{Accessibility Indices and Relative Ranks of Stations Along Extensions}

With one notable exception, stations along the new lines and extensions considered in

Alternatives B and C are on average, relatively less accessible than most existing stations (see Table 4.14).

Table 4.14

Accessibility Indices and Relative Ranks of Stations Along Extensions

\begin{tabular}{|c|c|c|c|c|}
\hline \multirow[b]{2}{*}{ New Lines and Extensions } & \multicolumn{2}{|c|}{ Accessibility Index } & \multicolumn{2}{|c|}{ Accessibility Rank } \\
\hline & Alternative B & Alternative C & $\begin{array}{r}\text { Alternative } \\
\text { B (out of } 90 \text { ) }\end{array}$ & $\begin{array}{r}\text { Alternative } \\
\text { C (out of 93) }\end{array}$ \\
\hline Overall average & 7.44 & 7.24 & $\mathrm{n} / \mathrm{a}$ & $\mathrm{n} / \mathrm{a}$ \\
\hline eBART average & 0.52 & 0.52 & 82.3 & 84.9 \\
\hline Railroad Avenue & 0.40 & 0.40 & 83 & 86 \\
\hline Sommersville Road & 0.96 & 0.96 & 80 & 83 \\
\hline Antioch Fairgrounds & 1.44 & 1.44 & 67 & 67 \\
\hline Hillcrest Avenue & 0.31 & 0.31 & 85 & 88 \\
\hline Oakley & 0.30 & 0.30 & 84 & 87 \\
\hline Brentwood & 0.12 & 0.12 & 88 & 91 \\
\hline Byron & 0.08 & 0.08 & 89 & 92 \\
\hline BART to Silicon Valley average & 6.66 & 6.67 & 39.3 & 39.3 \\
\hline Irvington & 1.73 & 1.78 & 66 & 66 \\
\hline Warm Springs & 1.21 & 1.24 & 70 & 71 \\
\hline South Calaveras & 2.44 & 2.45 & 54 & 53 \\
\hline Montague & 2.26 & 2.27 & 49 & 49 \\
\hline Berryessa & 3.15 & 3.15 & 34 & 34 \\
\hline Alum Rock & 7.19 & 7.20 & 19 & 19 \\
\hline Civic Center/SJSU & 19.04 & 19.05 & 9 & 9 \\
\hline Market Street-San Jose & 16.23 & 16.24 & 13 & 13 \\
\hline Caltrain to Downtown SF & 2.61 & 2.62 & 64 & 64 \\
\hline SF Transbay Terminal & 2.61 & 2.62 & 64 & 64 \\
\hline Dumbarton Rail average & $\mathrm{n} / \mathrm{a}$ & 0.80 & $\mathrm{n} / \mathrm{a}$ & 79.7 \\
\hline Willow Road & $\mathrm{n} / \mathrm{a}$ & 0.82 & $\mathrm{n} / \mathrm{a}$ & 78 \\
\hline Newark & $\mathrm{n} / \mathrm{a}$ & 0.73 & $\mathrm{n} / \mathrm{a}$ & 82 \\
\hline Centerville & $\mathrm{n} / \mathrm{a}$ & 0.84 & $\mathrm{n} / \mathrm{a}$ & 79 \\
\hline
\end{tabular}


Stations along the eBART line, Caltrain to Downtown San Francisco extension, and Dumbarton Rail line on average rank in the bottom half of stations for accessibility in both Alternatives B and C. Only stations on the BART to Silicon Valley extension on average rank in the top half of stations for accessibility.

Stations along the eBART extension rank the lowest in terms of accessibility out of the four new lines and extensions considered. With an index value of .52 in both Alternatives B and C, eBART stations rank 82.3 and 84.9 respectively out of all stations for accessibility. Byron and Brentwood stations along the eBART extension rank second and third lowest out of all stations for accessibility. The three Dumbarton Rail stations average the second lowest in terms of accessibility out of the new lines, with an average index value of .80 and average rank of 79.7 in Alternative C.

The SF-Transbay Center, the only station on the Caltrain to Downtown San Francisco extension, is the $64^{\text {th }}$ most accessible station in both Alternatives B and C. This relatively low rank on the surface may indicate that the Caltrain to Downtown San Francisco extension has little effect on accessibility, but this measure is deceptive in this case. The SF-Transbay Center station, when built, would be an extremely large job source. It would be the second largest job source when counting jobs within a quarter mile or half mile radius, and third largest when counting jobs within a one mile radius.

The jobs surrounding the SF-Transbay Center site induce large increases in accessibility in the closest stations to it from Alternative A, where the station is not considered, to 
Alternative B, where the station is considered. As shown in the previous section, the $4^{\text {th }}$ and King station, the next station south from the SF-Transbay Center has the highest rate of increase from Alternative A to B of over 1700 percent, which raises its rank from $67^{\text {th }}$ in Alternative A to $17^{\text {th }}$ in Alternative B. While the jobs surrounding the SF-Transbay Center increase accessibility greatly to stations nearby, it does not itself have a high accessibility index value because those nearby stations do not have high levels of employment surrounding them.

With an average index rank of 39.3 in both Alternatives B and C, the BART to Silicon Valley extension is the only one of the four whose stations rank on average in the top half for accessibility. Of the eight stations on the extension, they do not all have ranks near the average. Rather, three of the stations can be generalized as having high ranks, two stations having low ranks, and three in between. Civic Center/SJSU has the highest accessibility, ranked $9^{\text {th }}$ in both Alternatives B and C, with Market Street-San Jose and Alum Rock also in the top third of stations. Berryessa, Montague, and South Calaveras rank in the middle third, with Irvington and Warm Springs in the bottom third. With the slight skew of rankings towards the top and middle thirds of stations, and with the bottom third stations not being at the very bottom, the overall average rank for BART to Silicon Valley stations is in the upper half.

\subsubsection{Accessibility Benefit to Specific Lines}

A second way, other than rankings, to examine the accessibility of the new lines is to take a look at how much of the total accessibility gained by the whole system by building the 
new lines and extensions benefit the specific lines. This is done by looking at shares of the accessibility growth per line in the same way it was shown earlier for the sub-regional area types and sub-regional geographic areas.

As shown earlier, under the existing system alignment as calculated in Alternative A, the total accessibility of the whole system is 568.10. If all the new lines are built in a fullbuild scenario as calculated in Alternative C, the total accessibility of the whole system is 673.31. This is an increase of 18.5 percent.

Of the total systemwide accessibility growth that could occur if all the extensions are built, more than half goes to stations on the BART to Silicon Valley extension. The three other extensions had much lower shares of accessibility growth benefiting them, all less than five percent. The eBART extension had a marginally higher share than the Caltrain to Downtown San Francisco extension, and Dumbarton Rail (see Table 4.15).

Table 4.15

Shares of Growth In Accessibility Benefit By Line

\begin{tabular}{|c|c|c|c|}
\hline \multirow[b]{2}{*}{ Line } & \multicolumn{2}{|c|}{ Share of Accessibility Benefit } & \multirow{2}{*}{$\begin{array}{r}\text { Share of Growth } \\
\text { Benefiting Each } \\
\text { Line }\end{array}$} \\
\hline & $\begin{array}{r}\text { Existing Alignment } \\
\text { (Alternative A) }\end{array}$ & $\begin{array}{r}\text { Full Build Alignment } \\
\text { (Alternative C) }\end{array}$ & \\
\hline BART & $90.19 \%$ & $76.73 \%$ & $4.04 \%$ \\
\hline eBART & -- & $0.54 \%$ & $3.44 \%$ \\
\hline BART to Silicon Valley & -- & $7.93 \%$ & $50.73 \%$ \\
\hline Caltrain & $9.81 \%$ & $14.06 \%$ & $37.04 \%$ \\
\hline Caltrain-Downtown SF & -- & $0.39 \%$ & $2.49 \%$ \\
\hline Dumbarton Rail & -- & $0.36 \%$ & $2.27 \%$ \\
\hline TOTAL & $100 \%$ & $100 \%$ & $100 \%$ \\
\hline
\end{tabular}

Note: Transfer stations serving multiple lines are counted with the line the station was originally built for: Diridon, Millbrae, Santa Clara, $4^{\text {th }}$ and King counted with Caltrain; Pittsburg, Fremont, Union City counted with BART. 
The two measures, shares of accessibility growth and rankings, are similar in that the BART to Silicon Valley extension performs as most accessible under both, and Caltrain to Downtown San Francisco performs as third most accessible. The two measures differ in that eBART had the second highest share, but lowest average rank, and Dumbarton Rail had the lowest share, but second highest rank. Caltrain to Downtown San Francisco is third under both measures. This is not a particularly surprising result in that the share of accessibility growth captures total accessibility, and the rankings capture average accessibility. The eBART extension has seven stations to Dumbarton Rails three which makes it reasonable that eBART performs better on the total measure and Dumbarton Rail performs better on the average measure.

\subsubsection{Accessibility Attributable to Specific Lines}

In addition to looking at how much accessibility benefit stations on the new lines and extensions enjoy, it may be helpful to also look at how much accessibility those stations generate for other stations. For example, as shown previously, the SF-Transbay Center has a relatively low accessibility index value, but stations near it show large increases in index if the station is built. This indicates that the Caltrain to Downtown San Francisco extension has a value that is not being captured by the two previous benefit measures, index value, and share of accessibility benefit.

Of the growth in accessibility systemwide under the existing system alignment as calculated in Alternative A, and a full-build scenario as calculated in Alternative C, the BART to Silicon Valley extension is by far the largest contributor, accounting for nearly 
60 percent of the increase in accessibility. The Caltrain to Downtown San Francisco

extension contributes the second highest out of the four extensions, accounting for 12.41 percent. The eBART extension and Dumbarton Rail contribute significantly less than the other two, at just over three percent and one percent respectively (see Table 4.16).

Table 4.16

Shares of Growth In Accessibility Generation By Line

\begin{tabular}{|c|r|r|r|}
\hline \multirow{2}{*}{ Line } & \multicolumn{2}{|c|}{ Share of Accessibility Generation } & Share of Growth \\
\cline { 2 - 3 } & $\begin{array}{r}\text { Existing Alignment } \\
\text { (Alternative A) }\end{array}$ & $\begin{array}{r}\text { Full Build Alignment } \\
\text { (Alternative C) }\end{array}$ & $\begin{array}{r}\text { Attributable To } \\
\text { Each Line }\end{array}$ \\
\hline BART & $90.56 \%$ & $77.06 \%$ & $4.20 \%$ \\
\hline eBART & -- & $0.49 \%$ & $3.16 \%$ \\
\hline BART to Silicon Valley & -- & $9.35 \%$ & $59.82 \%$ \\
\hline Caltrain & $9.44 \%$ & $10.99 \%$ & $19.36 \%$ \\
\hline Caltrain-Downtown SF & -- & $1.94 \%$ & $12.41 \%$ \\
\hline Dumbarton Rail & -- & $0.16 \%$ & $1.04 \%$ \\
\hline TOTAL & $100 \%$ & $100 \%$ & $100 \%$ \\
\hline
\end{tabular}

Note: Transfer stations serving multiple lines are counted with the line the station was originally built for: Diridon, Millbrae, Santa Clara, $4^{\text {th }}$ and King counted with Caltrain; Pittsburg, Fremont, Union City counted with BART.

These results further solidify the relative importance of the BART to Silicon Valley extension among the other extensions as it shows the greatest impact under all three of the measures. Stations on the BART to Silicon Valley extension generate so much accessibility in fact that if all new lines were built, it would generate almost 10 percent of all accessibility systemwide. This would make it the third largest generator of accessibility behind existing BART stations, and existing Caltrain stations. While contributing less than Caltrain, the BART to Silicon Valley extension would come close to matching it, with the eight stations of the extension generating accessibility equal to approximately 85 percent of the 30 existing Caltrain stations. 
This measure also quantifies the aforementioned uncaptured value of the Caltrain to Downtown San Francisco extension. Despite having only one of the 19 stations along new lines and extensions, it generates almost one eighth of the growth in accessibility. Furthermore, it generates approximately $1 / 50^{\text {th }}$ of all accessibility systemwide in the full build alignment, but is only one of 93 stations in that alignment. So, while it enjoys relatively low accessibility itself, it is very impactful in making other stations more accessible, and thus, better opportunities for residential transit-oriented development.

While stations along new lines and extensions generate about three quarters of additional accessibility between the existing and full build scenarios, existing stations do generate additional accessibility in two ways. First, stations along the extensions have access to existing BART and Caltrain stations which they did not have before. Second, existing stations can have greater access to other existing stations as a result of shorter travel times thanks to new connections provided by the new lines.

\subsection{Surrounding Land Uses}

What exists surrounding station sites can be opportunities for or constraints to transitoriented development. For example, favorable zoning, like higher density residential or mixed-use zones, or available land, like vacant property can be seen as opportunities. Unfavorable, or unchangable surrounding land uses, like parks or institutional property can be seen as constraints. 
Some land uses can be seen as either opportunities or constraints. For example, industrial areas could be brownfield redevelopment opportunities, or constraints due to their continuing presence being incompatible with residential land uses. Agricultural areas could be opportunities based on sheer available land, or constraints due to a desire to preserve prime farmland. Thus, analyzing surrounding land uses as opportunities or constraints can get tricky, as it can depend on other variables that are beyond the actual surrounding land uses, like political will, willingness to develop, and other varying values people place on land.

Short of doing full, in depth, land use inventories of all parcels surrounding the 93 station areas looked at in this study, one particular hard land use constraint can be examined with a more cursory look at surrounding land uses. Figure 4.10 shows a generalized land use map of the Bay Area as assembled by the Association of Bay Area Governments (ABAG), the regional planning body of the area. This generalized land use map was constructed by taking general plan land use maps from jurisdictions in the region and recoding the specific land uses from those individual documents into generalized land uses for the region.

The hard land use constraint that can be analyzed from this map is the presence of low density, single family residential areas. This is a hard constraint because it is constitutionally locked in to California law. Proposition 99, passed in the June 2008 primary election includes a provision to Article I, Section 19 of the California 
constitution that prohibits the acquisition of an owner-occupied residence via eminent domain for the purpose of conveyance to a private person.

To redevelop a low density, single family area to higher density residential or mixed-use for transit-oriented development would expectedly require such a taking unless the land is not-occupied, the unit renter-occupied, the owners are willing to sell rights to a developer, or a public agency, and not a private person is the developer of the TOD. Since public agencies have generally not been in the public housing construction business over the last several decades, it is unlikely that all properties in a single family area that are desired to be redeveloped would have one of the first three conditions be true.

Proposition 99 was one of several ballot measures across the country, including two in California, that sought to respond to the Kelo vs. New London (2005) Supreme Court decision which upheld the taking in Connecticut of an owner-occupied dwelling for the purpose of conveyance to a private party in the interests of economic development (California Secretary of State, 2008). 
Figure 4.10

Generalized Land Uses in the San Francisco Bay Area

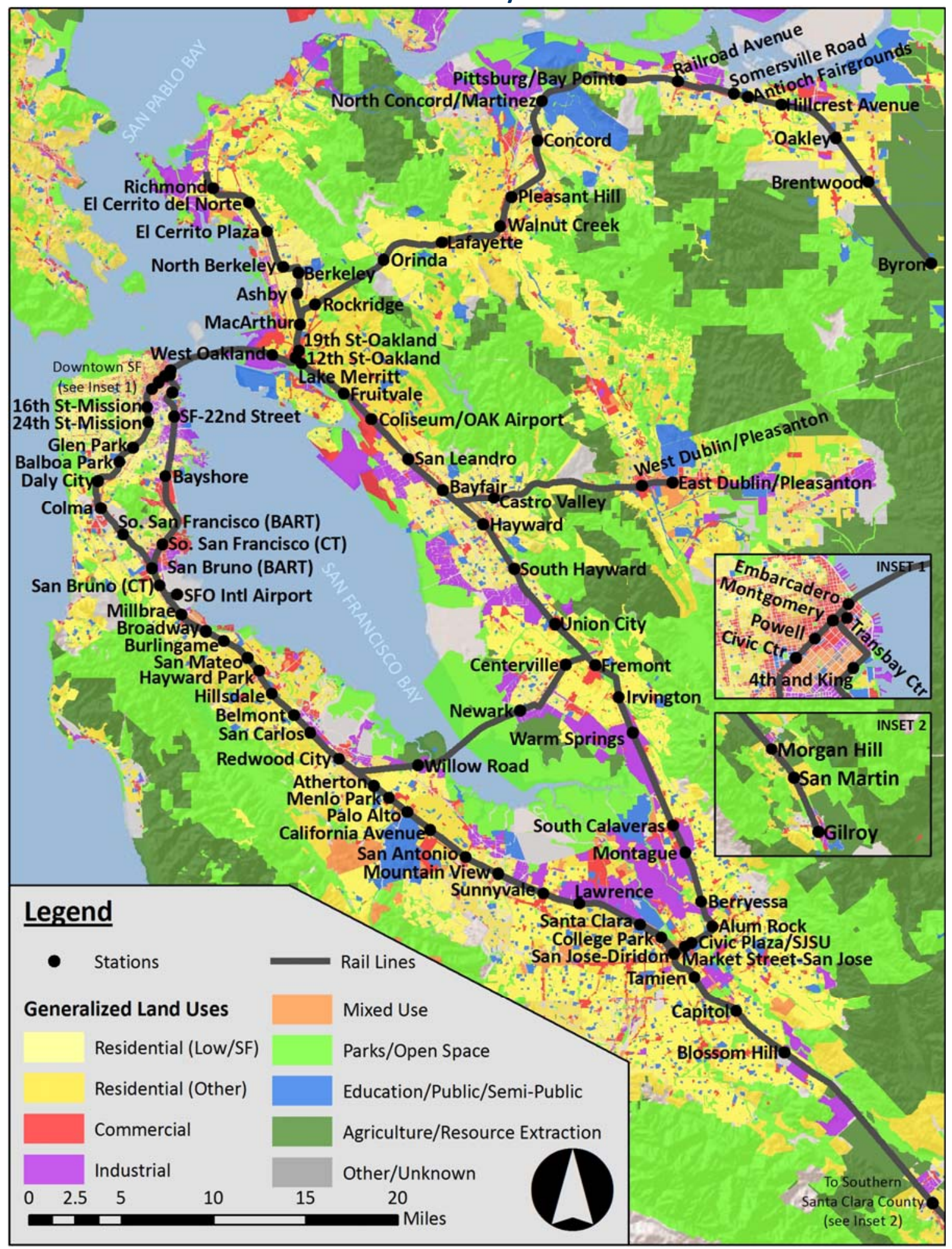

Source: Association of Bay Area Governments, SF-Metropolitan Transportation Commission, ESRI 
Looking within one quarter mile of stations, 58 of 93 stations have some low density residential areas surrounding them. Since the distribution of land uses over an area is not homogeneous, the number of stations that have low density areas surrounding them predictably increases at greater distances away from stations. Looking within one half mile, 75 stations, and looking within one mile, 86 stations, have some surrounding low density residential areas.

Within one quarter mile, the Caltrain station in the extremely affluent town of Atherton is the most constrained for TOD. Almost the entire area within one quarter mile is taken up by low density housing. North Berkeley BART, and San Bruno Caltrain, the second and third most constrained stations at this distance are only half as constrained as Atherton with just over 50 percent of their surrounding areas taken up by low density housing. 18 stations have between 25 to 50 percent of their areas, and 37 stations have less than 25 percent, but greater than zero percent of their surrounding areas taken up by low density housing.

The 20 stations with the highest share of low density housing surrounding them within one quarter mile are shown in Table 4.17. Note, the land uses as compiled by ABAG represent only land use designations, and not actual build out. 
Table 4.17

Top 20 Stations by Percent of Station Areas That Are Low Density Res. Within $1 / 4$ Mile

\begin{tabular}{|c|c|r|}
\hline Rank & Station & $\begin{array}{r}\text { Percent of Surrounding Area } \\
\text { that is Low Density Residential }\end{array}$ \\
\hline 1 & Atherton & $96.7 \%$ \\
\hline 2 & North Berkeley & $52.3 \%$ \\
\hline 3 & San Bruno (Caltrain) & $51.0 \%$ \\
\hline 4 & Hayward Park & $45.6 \%$ \\
\hline 5 & Glenn Park & $45.2 \%$ \\
\hline 6 & North Concord & $37.7 \%$ \\
\hline 7 & El Cerrito Plaza & $37.1 \%$ \\
\hline 8 & San Carlos & $36.2 \%$ \\
\hline 9 & Antioch Fairgrounds & $32.4 \%$ \\
\hline 10 & Castro Valley & $31.6 \%$ \\
\hline 11 & El Cerrito del Norte & $28.7 \%$ \\
\hline 12 & 25 th St-Mission & $28.5 \%$ \\
\hline 13 & Concord & $28.5 \%$ \\
\hline 14 & Sunnyvale & $28.4 \%$ \\
\hline 15 & San Bruno (BART) & $28.2 \%$ \\
\hline 16 & Alum Rock & $28.0 \%$ \\
\hline 17 & Bayfair & $27.9 \%$ \\
\hline 18 & Balboa Park & $27.2 \%$ \\
\hline 19 & Gilroy & $25.8 \%$ \\
\hline 20 & Hillsdale & $25.6 \%$ \\
\hline
\end{tabular}

A map displaying shares of low density housing surrounding all stations within one quarter mile can be seen in Figure 4.11. Full data is presented in The Appendix, Table $\mathrm{X} 4.11$. 
Figure 4.11

Percent of Station Areas That Are Low Density Residential Within $1 / 4$ Mile

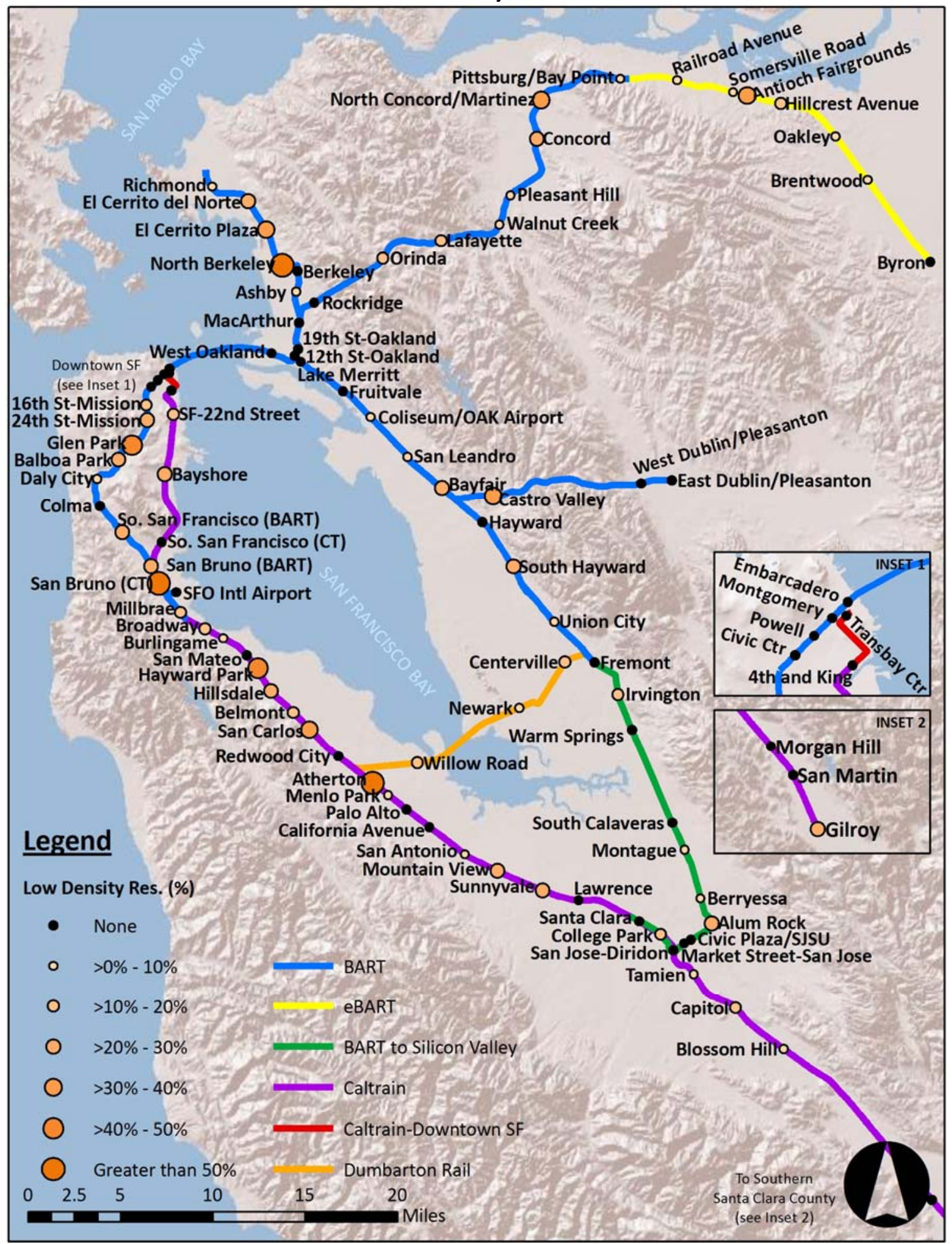

Source: Association of Bay Area Governments, SF-Metropolitan Transportation Commission, ESRI 
Expanding out to within one half mile, again Atherton station is the most constrained with almost 83 percent of its surrounding area taken up by low density housing. Glenn Park, at just over 54 percent is the only other station with more than half of its surrounding area taken up. 28 stations have between 25-50 percent of their areas, and 45 stations have less than 25 , but greater than zero percent of their surrounding areas taken up by low density housing.

The 20 stations with the highest share of low density housing surrounding them within one half mile are shown below in Table 4.18.

Table 4.18

Top 20 Stations by Percent of Station Areas That Are Low Density Res. Within $1 / 2$ Mile

\begin{tabular}{|c|c|r|}
\hline Rank & Station & $\begin{array}{r}\text { Percent of Surrounding Area } \\
\text { that is Low Density Residential }\end{array}$ \\
\hline 1 & Atherton & $83.0 \%$ \\
\hline 2 & Glenn Park & $54.2 \%$ \\
\hline 3 & San Bruno CT & $48.5 \%$ \\
\hline 4 & North Berkeley & $47.4 \%$ \\
\hline 5 & Hillcrest Avenue & $44.2 \%$ \\
\hline 6 & El Cerrito del Norte & $44.2 \%$ \\
\hline 7 & El Cerrito Plaza & $42.1 \%$ \\
\hline 8 & 24 th St-Mission & $39.2 \%$ \\
\hline 9 & Orinda & $38.2 \%$ \\
\hline 10 & Antioch Fairgrounds & $38.1 \%$ \\
\hline 11 & Balboa Park & $38.0 \%$ \\
\hline 12 & Hayward Park & $38.0 \%$ \\
\hline 13 & Belmont & $37.7 \%$ \\
\hline 14 & San Carlos & $36.2 \%$ \\
\hline 15 & Gilroy & $35.1 \%$ \\
\hline 16 & Irvington & $33.4 \%$ \\
\hline 17 & Castro Valley & $33.0 \%$ \\
\hline 18 & Bayfair & $32.8 \%$ \\
\hline 19 & Hillsdale & $32.6 \%$ \\
\hline 20 & North Concord & $32.6 \%$ \\
\hline
\end{tabular}

A map displaying shares of low density housing surrounding all stations within one half mile can be seen in Figure 4.12. Full data is presented in The Appendix, Table X4.12. 
Figure 4.12

Percent of Station Areas That Are Low Density Residential Within $1 / 2$ Mile

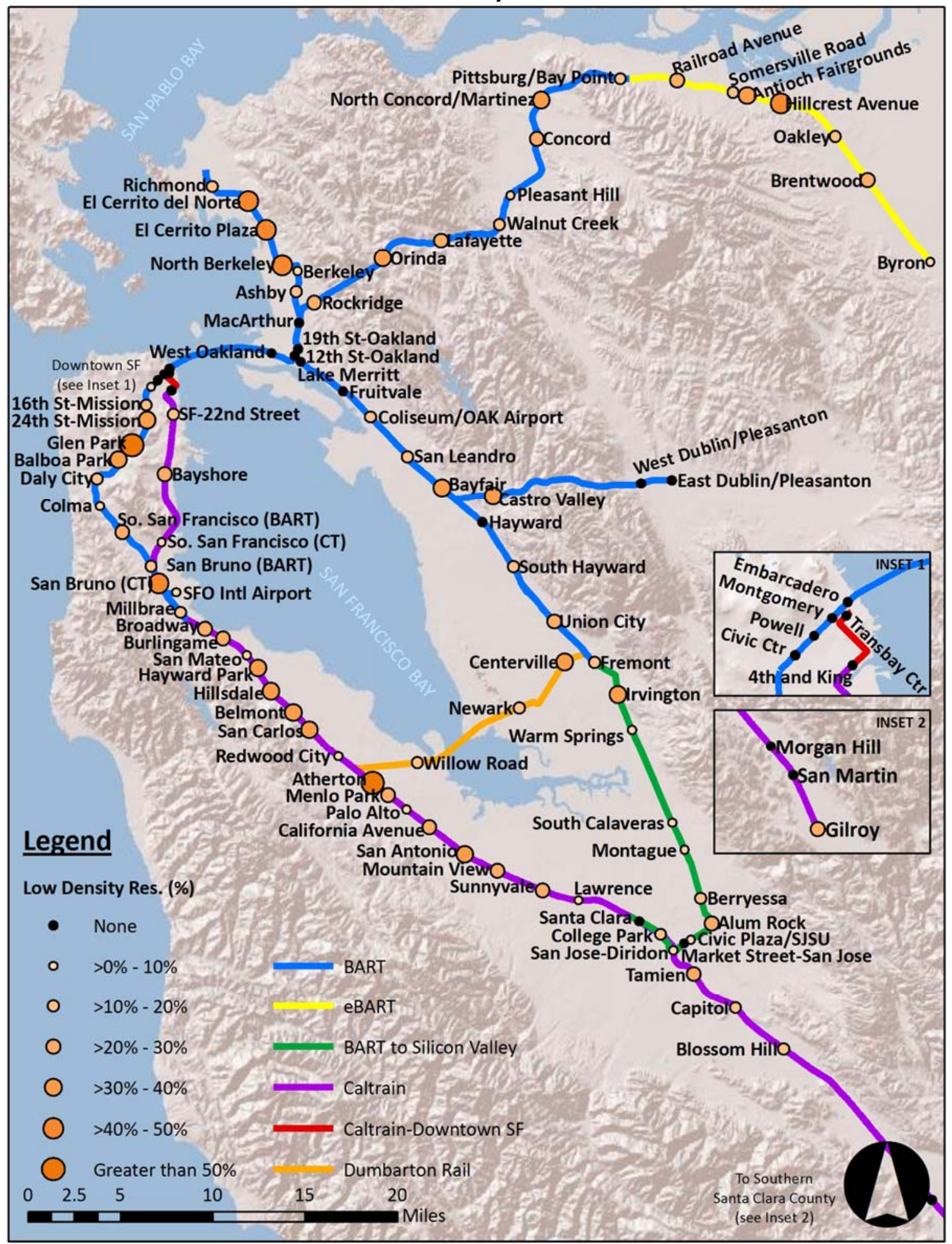

Source: Association of Bay Area Governments, SF-Metropolitan Transportation Commission, ESRI 
Atherton is the most constrained at all three, although its share is significantly lowered at this distance to below two thirds. Irvington, Hillcrest Avenue, Balboa Park, Orinda, Menlo Park, El Cerrito del Norte, and Glenn Park are the other seven stations with more than half their areas taken up by low density residential. Thirty-six stations have between 25-50 percent of their areas, and 42 stations have less than 25, but greater than zero percent of their surrounding areas taken up by low density housing.

The 20 stations with the highest share of low density housing surrounding them within one mile are shown in Table 4.19.

Table 4.19

Percent of Station Areas That Are Low Density Residential Within 1 Mile

\begin{tabular}{|c|c|r|}
\hline Rank & Station & $\begin{array}{r}\text { Percent of Surrounding Area } \\
\text { that is Low Density Residential }\end{array}$ \\
\hline 1 & Atherton & $63.4 \%$ \\
\hline 2 & Irvington & $58.2 \%$ \\
\hline 3 & Hillcrest Avenue & $53.0 \%$ \\
\hline 4 & Balboa Park & $51.9 \%$ \\
\hline 5 & Orinda & $51.8 \%$ \\
\hline 6 & Menlo Park & $50.5 \%$ \\
\hline 7 & El Cerrito del Norte & $50.1 \%$ \\
\hline 8 & Glenn Park & $50.0 \%$ \\
\hline 9 & Centerville & $49.7 \%$ \\
\hline 10 & Hillsdale & $48.5 \%$ \\
\hline 11 & Hayward Park & $46.0 \%$ \\
\hline 12 & Union City & $44.6 \%$ \\
\hline 13 & California Avenue & $44.2 \%$ \\
\hline 14 & Richmond & $43.6 \%$ \\
\hline 15 & Antioch Fairgrounds & $43.0 \%$ \\
\hline 16 & Lafayette & $42.8 \%$ \\
\hline 17 & El Cerrito Plaza & $42.8 \%$ \\
\hline 18 & Brentwood & $40.7 \%$ \\
\hline 19 & North Berkeley & $40.4 \%$ \\
\hline 20 & San Bruno CT & $39.9 \%$ \\
\hline
\end{tabular}

A map displaying shares of low density housing surrounding all stations within one mile can be seen in Figure 4.13. Full tabular data can be found in the Appendix, Table X4.13. 
Figure 4.13

Percent of Station Areas That Are Low Density Residential Within 1 Mile

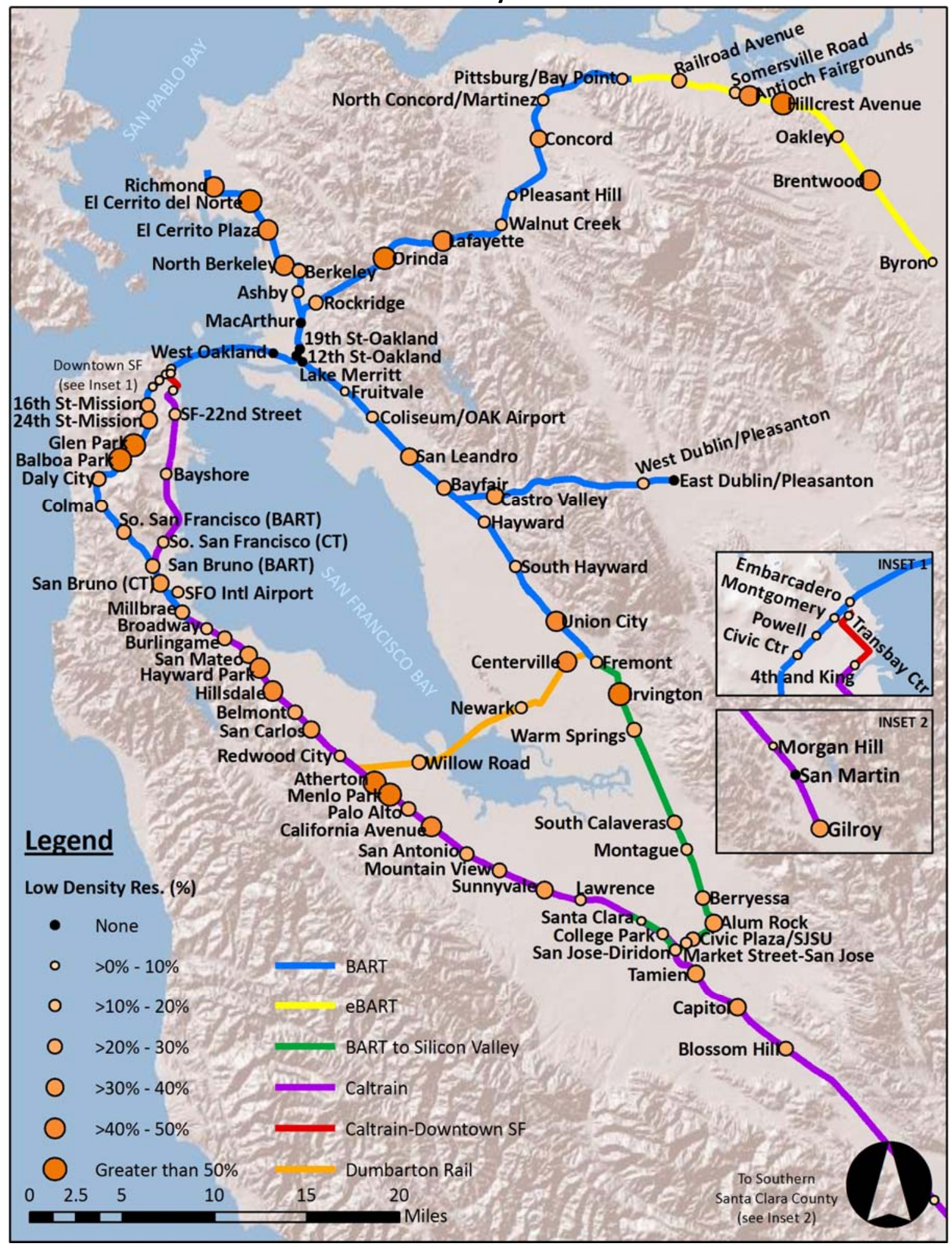

Source: Association of Bay Area Governments, SF-Metropolitan Transportation Commission, ESRI 
When comparing two stations at the same radius distance, obviously the station with the greater share of their surrounding area taken up by low density housing areas is more constrained than the stations with a lower share of their surrounding area taken up. It can also be argued however that between different distances, the percent of a stations surrounding area taken up by low density housing is more of a constraint at a smaller radius than that same percent taken up at a larger radius.

For example, when looking within one quarter mile from stations, an approximately 126 acre area is encompassed. If 50 percent of this area is constrained by low-density housing, only 63 acres are left available for TOD. If the distance is expanded to one-half mile, the area quadruples to 503 acres. If 50 percent is constrained now, there are still 251 acres left available from TOD. Expanding to one mile, 1,005 acres are still available if 50 percent of the area is constrained. Thus, if a TOD project of for example 100 acres is proposed, it would not fit around stations that have 50 percent of their area within one quarter mile constrained by low density housing. However, if a station had 50 percent of its area within one half mile constrained, that same 100 acre project could conceivably fit five times. Also note, the term 'available for TOD' above is used loosely, as these available areas can still be constrained by a multitude of land use related or other factors, but just not by owner-occupied, single family housing.

The figures shown in previous tables capture low density, single family housing, however, not all owner-occupied, single family housing, which is the actual constitutional constraint, exists in low-density areas. Owner-occupied, single family housing can exist 
in other areas like medium-density, high-density, and mixed-use areas. Owner-occupied, single family housing in these areas can be a part of successful TOD, being on smaller lots such that these neighborhoods are still walkable and foster transit accessibility. So, while the figures discussed here capture a large chunk of single-family housing, it intentionally does not capture it all.

Areas were captured as low-density, single family residential if their land use designation, as defined by the original general plan document they were taken from had some derivation of low density or single family in their title. For example, very low density residential, low density residential, and medium low density residential were included as well as single family or low-density, single family. If the designation included the word medium, it also had to include the word low in order to be included. If the designation included the term multi-family, even if it also said low, it was not included. Thus, designations like medium-density single family and low-density multifamily were not included. More technical land use designations like R-1 and those that specified a density, generally less than 10 dwelling units per acre, were included. Designations called single family, with no qualifier, were included in the calculations, which may result in a small capture of non-constraining single family residential if these areas are in fact small-lot single family units.

\subsection{Opportunities for TOD at Specific Station Sites}

The preceding sections have detailed accessibility under different conditions, such as the three network configurations, different radii distances, averages, etc. To try and predict 
today how the future may unfold, one can interpret the multiple results in different ways. This section attempts to state an overall determination for the opportunity of transitoriented development at specific station sites.

In this determination, stations are ranked based off a score calculated from some of the previously presented results. This calculation is one subjective way this interpretation can be made. If someone has different values or wants to emphasize different characteristics of accessibility, they can make a different interpretation than the one presented here.

The score for given stations as presented begins by summing the accessibility index for the station under all three Alternative Network Configurations. This assumes that a station that is relatively highly accessible in multiple network configurations is a better opportunity than a station that is only highly accessible in one configuration.

Second, this sum is multiplied by the percent of that stations surrounding area that is not single-family or low-density residential. If, for example, a station has its entire surrounding are occupied with single family residential, it is blocked from redevelopment to higher density transit-oriented development, regardless of how accessible the site is. This stations score is thus whittled down to zero. Conversely, the greater the non-low density area is surrounding a station, the more it can possibly fulfill its opportunity for transit-oriented development, and thus the more of its summed accessibility score it keeps. In this calculation, the percent of surrounding areas that are low-density residential within one half mile was used. 
It is of note that some of the most accessible stations in Alternative B and Alternative C are new stations that do not exist in Alternative A. A zero index value is added into the sum for these stations, representing a trade-off of sites being good opportunities for transit-oriented development in the present versus the future. As will be discussed, some stations that do not exist in Alternative A are so highly accessible in Alternative B and Alternative $\mathrm{C}$ that they still register in the first quartile of TOD opportunities as scored in this determination.

The generalized score for the individual stations is depicted graphically by rank quintiles in Figure 4.14. Score values and rank numbers can be seen in the Appendix, Table X4.14.

With 94 stations in the study, the quintiles contain either 18 or 19 stations. The stations in the top quintile are (from highest score to lowest score):

Embarcadero, Powell, Montgomery, Civic Center, $16^{\text {th }}$ Street-Mission, $12^{\text {th }}$ Street-Oakland, $19^{\text {th }}$ Street-Oakland, $24^{\text {th }}$ Street-Mission, Diridon, Lake Merritt, MacArthur, Civic Center-SJSU, West Oakland, Market Street-San Jose, Ashby, $4^{\text {th }}$ and King, College Park, North Berkeley

17 of 19 of these stations are in the three largest cities of San Francisco, Oakland, and San Jose. The two stations outside of these three cities are both in Berkeley. Two stations, Civic Center-SJSU and Market Street-San Jose are on the BART to Silicon Valley extension. These stations thus have an Alternative A index of zero, yet still are in the top quintile. 
Looking at the second highest quintile, it can be concluded that generally, that the better, non central city, transit-oriented development opportunities are on the Peninsula. Of the 19 stations in the second quintile, 12 are on the Peninsula, five are in the East Bay, and 2 are in the South Bay. The 19 stations in the second highest quintile are (from highest score to lowest score):

Glenn Park, Berkeley, Balboa Park, San Mateo, Coliseum/OAK Airport, Alum Rock, Menlo Park, Daly City, Rockridge, Pleasant Hill, Colma, Millbrae, Hillsdale, Palo Alto, Burlingame, San Bruno BART, So. San Francisco BART, Santa Clara, San Leandro

The 18 stations in the bottom quintile, and thus poorest opportunities for transit-oriented development are (from lowest score to highest score):

Gilroy, Byron, Brentwood, Hillcrest Avenue, Morgan Hill, San Martin, Oakley, Centerville, Railroad Avenue, Newark, Willow Road, Blossom Hill, Pittsburgh, Atherton, Fremont, Capitol, Sommersville Road, and Antioch Fairgrounds.

Of these 18, 7 are on existing lines and 11 are on new lines. Of the seven stations on existing lines, five are on Caltrain. 
Figure 4.14

Generalized Opportunity for TOD at Individual Stations (by Rank Quintile)

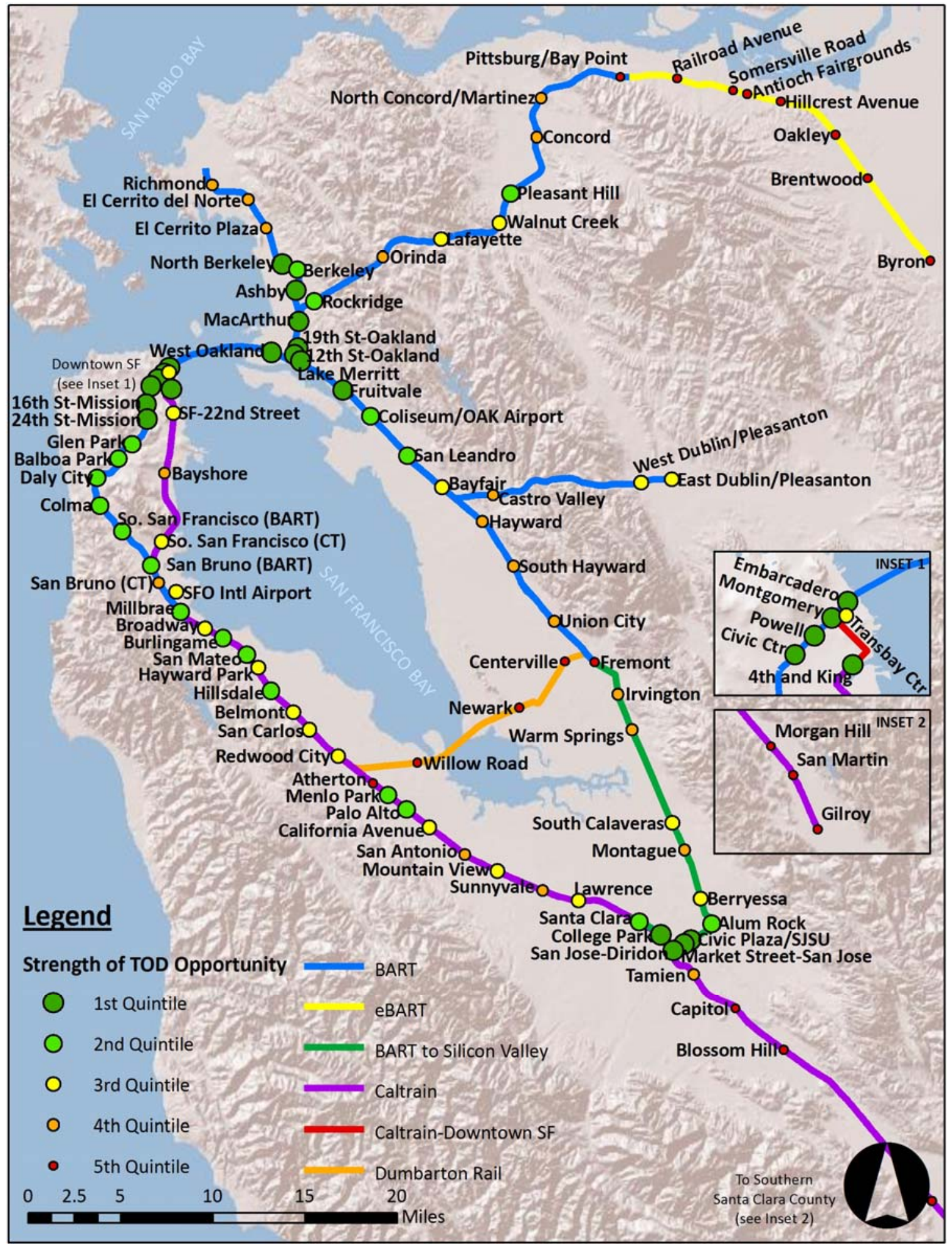

Source: SF-Metropolitan Transportation Commission, ESRI Shaded Relief Base Map 


\section{SUMmARY AND POLICY IMPLICATIONS}

\subsection{Considerations for Paradigm Shift}

Many groups have been seeking a paradigm shift away from automobile-oriented transportation and land use to more transit-oriented transportation and land use. These groups cite many issues which include environmental, economic, consumer preference, and social/equity concerns.

Environmental: Transportation is a great consumer of energy, particularly of nonrenewable and polluting forms, which leads to an inordinate release of climate altering carbon dioxide.

Statistics from the Bureau of Transportation Statistics (2006) and the Energy Information Administration (2008) show that the transportation sector is behind only the industrial sector in energy consumption, and second to none in carbon dioxide output. 97 percent of the nearly 30 quadrillion BTUs of energy consumed by the transportation sector is from the burning of fossil fuels. A transition to rail transit in particular could lower this energy consumption as automobiles have an energy intensity more than double that of rail.

The transportation sector is responsible for the second greatest energy use out of the four main economic sectors. It is only behind the industrial sector, and ahead of the residential and commercial sector in energy use. Around 97 percent of the nearly 30 quadrillion BTUs of energy consumed by the transportation sector is from the burning of fossil fuels. 
This burning of fossil fuels leads to an even more disproportionate release of carbon dioxide. The transportation sector is the greatest generator of carbon dioxide out of the four main sectors. Automobile travel uses approximately 3,500 BTU per passenger mile traveled, while various forms of rail travel use in the neighborhood of 1,000-1,500 BTU per passenger mile traveled.

Economic: Predominantly automobile oriented travel can have significant economic impacts, both for individuals and society at-large.

Statistics from the Energy Information Administration (2009) shows that adjusted for inflation, gasoline prices are still at historical highs and projected to get higher, despite drops from record high prices in 2008.

Burchell and Mukherji (2009) project that development costs in a traditional autooriented approach are more expensive in the long run compared to development in a compact, and thus, more transit-supporting approach. This compact, Managed Growth scenario, has lower costs related to several development impacts including new utility infrastructure, new transportation infrastructure, and fiscal costs for providing services by jurisdictions.

Consumer Preference: Levine, Inam, and Torng (2005) look at consumer preferences, with case studies of residents in Atlanta and Boston. They make the argument for more transit-oriented development finding that there is an underserved demand for alternatives. 
Equity: Blumberg and Ong (1998) and Cervero, Tsai, et al. (2002) identify social equity benefits and needs related to accessibility.

Blumberg and Ong find that in their case study of Los Angeles, increasing accessibility to jobs contributes to decreasing enrollment in welfare and can thus help promote socioeconomic equity. They cite that this result is consistent with several other pieces of research from the early to mid-1990s looking at employment opportunities and welfare use.

Cervero, Tsai, et al., 2002, also highlights an additional accessibility-related equity issue in California. They find transit accessibility lacking in reverse commute directions, with particularly strong impacts on low-income reverse commuters. Low-income workers make reverse commutes at approximately double the rate of all workers in general. Many of these workers do not own cars and thus face exceedingly long travel times, up to four times longer than automobiles, on public transit networks oriented in the standard commute network.

\subsection{Four Key Questions About Bay Area Extensions}

This study (Section 1.1) outlined four key questions to be asked in the examination of accessibility for the specific case of the San Francisco Bay Area's rail transit network and proposed extensions. These questions are:

(a) Whether existing stations are highly accessible and thus good opportunities for transit-oriented development 
(b) Whether stations along proposed extensions are highly accessible and thus good opportunities for transit-oriented development

(c) The degree to which existing stations increase in accessibility as a result of extensions to the network

(d) The overall total accessibility of the regional rail network

\subsubsection{Accessibility of Existing Stations}

Accessibility of existing stations in the existing network was calculated in Alternative Network Configuration A. The highest accessibility stations are generally in San Francisco (the second largest city), and Oakland (the third largest city). The next highest accessibility stations are generally in locations close to San Francisco and Oakland, with accessibility tapering down with increasing distance away from these two cities. There is some fluctuation in this trend with moderately high accessibility at stations nearby to satellite job centers.

While high accessibility is found in San Francisco and Oakland, it is not found in San Jose, the largest city in the region. A station in San Jose ranks as low as fourth lowest out of 74 stations considered in Alternative Network A.

Embarcadero Station in San Francisco is the most accessible station with an index of 78.48. All double-digit index stations are in San Francisco or Oakland. North Berkeley is the highest accessibility non-San Francisco, non-Oakland Station, ranked $13^{\text {th }}$ with an index of 8.93. Gilroy, with an index of .03 is the lowest accessible station in the network.

Generally, BART stations show greater accessibility than Caltrain. The top 17 stations in accessibility are all along BART and the bottom four are all along Caltrain. 


\subsubsection{Accessibility of Stations along Extensions}

Stations along the extensions are generally less accessible than existing stations. With Alternative Network A, the average accessibility index is 7.68. Adding three extensions in Alternative Network B, the average drops to 7.44. Adding the fourth extension in Alternative Network C, the average drops to 7.24.

BART to Silicon Valley is the only one of the four extensions that has stations that on average rank in the upper half of all stations. In Alternatives B and C, BART to Silicon Valley stations on average rank 39.3 out of all stations. Actually, the average index for BART to Silicon Valley stations is lower than the overall average index for all stations. However, since out of the eight new stations in the extension, three are in the top third, and two are in the middle third, the ranks fall in the upper half.

Stations on Caltrain to Downtown San Francisco, Dumbarton Rail, and eBART all rank in the lowest third of all stations. SF-Transbay Center on the Caltrain to Downtown San Francisco ranks 64th in both Alternatives B and C and is barely in the bottom third. Stations on Dumbarton Rail and eBART are solidly in the bottom third.

\subsubsection{Increases in Station Accessibility due to Extensions}

Almost one third of stations experience double-digit increases in accessibility from Alternative Network A to Alternative Network B. 22 stations increase more than 10 percent, with five of these stations experiencing much more dramatic triple-digit and quadruple-digit increases. 4th and King experiences the largest increase at over 1,700 
percent, followed by Diridon at over 1,000 percent. Tamien, SF-22nd Street, and Fremont increase over 100 percent.

Much more limited growth occurs moving from Alternative Network B to Alternative Network C. Only 14 stations have increases greater than 1 percent, with Union City showing the greatest increase at just under 20 percent.

\subsubsection{Total Accessibility of Regional Network}

For Alternative Network A, the existing network, summing the accessibility indices of all stations produces a total systemwide accessibility index of 568.1. Alternative B adds 16 stations on three extensions and raises the systemwide index 17.8 percent to 669.5.

Alternative C adds only three stations on the Dumbarton Rail extension. The increase in systemwide index is thus expectedly lower from Alternative B to C than from Alternative A to $\mathrm{B}$, at .6 percent to 673.3. Comparing Alternative C back to Alternative A, the 19 stations added between Alternatives $\mathrm{A}$ and $\mathrm{C}$ results in a systemwide index increase of 18.5 percent.

From Alternative A to B, over one third of the systemwide accessibility growth occurs at Central City - Central Business District stations. Slightly less than one third of growth occurs at Central City - Non-CBD stations, and just over one quarter occurs at Inner Ring Suburb Stations. Only four percent occurs at Outer Ring Suburbs. Geographically, approximately 60 percent of increase in accessibility takes place in the South Bay, with another one third on the Peninsula. 
From Alternative B to C, over 96 percent of growth occurs in Inner Ring Suburbs. This is not surprising, as Dumbarton Rail, the only extension added in Alternative C runs through and connects inner-ring suburbs only. Geographically, more than half of increase in accessibility takes place in the Lower, Coastal East Bay, with slightly more than one third on the Lower Peninsula.

\subsection{Policy Implications of Accessibility Results}

\subsubsection{Prioritization of Extensions}

Overall, the four extensions, if all built, have the potential to increase heavy and commuter rail accessibility systemwide in the Bay Area by approximately 18 percent. While not an insignificant increase, the four scenarios add 19 stations to the network, an increase in total stations of almost 26 percent. Thus, the increase in accessibility does not keep up with increase in total stations.

The impact of each extension is not even however, some lines perform well in accessibility measures, others do not. Thus, if prioritizing the four lines in order of the strongest performing extension to the weakest, they would be ordered as follows:

1. BART to Silicon Valley

2. Caltrain to Downtown San Francisco

3. eBART

4. Dumbarton Rail

The BART to Silicon Valley extension shows a clear accessibility value, as its potential stations are both highly accessible themselves and contribute greatly to the accessibility of other stations by encompassing large numbers of jobs. The BART to Silicon Valley 
extension would arguably be as important to regionwide accessibility as the entire existing Caltrain system, with its seven stations contributing nearly as much to accessibility of other stations as Caltrain's 33 stations.

The Caltrain to Downtown San Francisco extensions also shows very high improvements in accessibility. This is not so much the case in the lone station of the extension, the SFTransbay Center, itself having high accessibility. However, the SF-Transbay Center spurs large increases in stations leading up to it and would contribute almost double to accessibility of other stations than the average of all stations

eBART and Dumbarton Rail perform relatively poorly in improving accessibility. Stations on these lines have relatively low accessibility values, their impacts on nearby stations are modest at best, and their impact on systemwide accessibility is slight. This is not particularly surprising for eBART, which extends into the exurban fringe of the region. It is somewhat surprising for Dumbarton Rail, since it is regionally central. Apparently, the stations on Dumbarton Rail are sufficiently distant from the three main job centers, despite being between all three, for its stations not to be highly accessible. The line apparently also does not have enough jobs around station areas now to contribute highly to accessibility, nor does it constitute enough of a shortcut for travelers.

In late 2008, the MTC faced controversy and a lawsuit regarding a prioritization decision involving two of the four proposed extensions. The contentious move was a transfer of 91 million dollars from Dumbarton Rail to BART to Silicon Valley. If using accessibility as 
the main measure to evaluate the two, the obvious choice would be to go with BART to Silicon Valley. Considering BART to Silicon Valley enjoys and generates a majority of additional accessibility benefits, and not just a plurality out of the four lines, between the current system and full build scenario, it is an easy choice.

\subsubsection{Characteristics of More Accessible Extensions}

BART to Silicon Valley and Caltrain to Downtown San Francisco share the characteristic of reaching or going through large activity centers. This appears to be the most key characteristic as eBART and Dumbarton Rail do not pass through any.

Forming connections between lines, or being connected on both sides of an extension, also appears to be important. BART to Silicon Valley has this characteristic and has greater accessibility than Caltrain to Downtown San Francisco which does not.

Connections seem less critical than activity centers because of the case of Dumbarton Rail, which performs poorest out of the four extensions. While the benefit of the added connection can be seen moderately at a couple of stations most immediately beyond the extension, the lack of activity centers along it makes it so that its impact does not go far. Caltrain to Downtown San Francisco hitting one activity center proved significantly more important than Dumbarton Rail’s added connection.

However, the benefit of added connections should not be overly dismissed because of the Dumbarton Rail case, as this particular connection may be poorly located. With no activity centers along it, the benefit of the connection would have to come through travel 
time reductions to one of the three main job centers. However, it is a similar distance going to Oakland from the West or San Francisco from the East using Dumbarton Rail than using the existing Transbay Tube on BART. Further, it is longer reaching San Jose by going across Dumbarton Rail than just taking Caltrain in the West, or BART/BART to Silicon Valley in the East, directly to San Jose.

\subsubsection{Importance of Transit-Oriented Development Supporting Policies}

Cervero, Castellanos, Rich, and Sarosa (1996) performed a retrospective on the BART system, and development around stations 20 years into the lifetime of the system and found that access to BART was “an important contributor”, but not by itself “a significant condition to significant land development around stations.” So, while BART to Silicon Valley and Caltrain to Downtown San Francisco perform relatively well in accessibility compared to eBART and Dumbarton Rail, it is not a guarantee that stations on the first two lines will automatically foster successful transit-oriented development, and the stations on the other two will not.

The other critical factors that Cervero, Castellanos, Rich, and Sarosa (1996) identify as important in determining the development of future transit-oriented development are,

“The degree to which the Bay Area embraces stronger regional planning, turns to marketbased approaches, or continues with the status quo.”

This will be important for all four lines. If done on the more accessible pair, new developments can take advantage of their inherent accessibility and support strong 
transit-oriented development. Arguably, this is more important on the less accessible pair, as without the inherent accessibility advantage, they will really need significant development action if the region is to take full advantage of the investment made in the extensions.

What these lower accessibility extensions require from planners intensification of development of satellite job centers along the lines instead of mostly on highways, which has been the prevalent, status-quo trend in the region. Development around the Walnut Creek and Pleasant Hill BART stations, a satellite job center that developed during the age of BART, would be a good example to follow.

The presence of this satellite job center leads to moderately high accessibility index values along this section of the BART system. If a baseline calculation of accessibility similar to what was done in this study was done for this area back in the 1970s, it would have registered relatively low accessibility index values as well based on its somewhat close, but not immediate proximity to Oakland and San Francisco. The purposeful establishment of job centers at these stations made the difference.

\subsection{Questions for Further Study}

Several issues can potentially be delved into further growing from this study, looking at topics covered in more detail, or examining questions raised in the report. 
The accessibility indices as shown in this report are based on existing employment figures, and thus show opportunities for transit-oriented development that exist immediately upon the completion of the extensions, without further job growth. A logical next step would be try and project where employment growth may occur and look at how accessibility would increase in that event. Such projections could be based on several criteria, including how employment has grown along the existing system or the stationarea land use policies of jurisdictions where extensions are located. Alternatively, such a study could try and model where employment growth could be placed and have the greatest impact.

Opportunities are also calculated based on access to all jobs. As discussed in the literature review, accessibility needed and deficiencies are not even across groups. Low, income, and reverse commuters experience much less transit accessibility than commuters as a whole. Further study could try and look at how to improve accessibility for these commuters in particular. Such a study would likely need a discussion on how to model this problem, as some of the assumptions made in the methodology of this report may not be the most appropriate for these sub-groups. For instance, if these workers are not finding employment in central job centers, will they be able to find them in a transitoriented urban form that tries to mimic these centers? What kind of service would be needed to be provided to serve these groups, and allow them to enjoy more fully the benefit of the investments in rail transit extensions? 


\subsection{Overall Conclusions}

The four extensions studied in the San Francisco Bay Area create a marked increase in accessibility, but arguably less than might be optimally desired. Two of the lines, BART to Silicon Valley and Caltrain to Downtown San Francisco demonstrate notable increases in accessibility, while two others, eBART and Dumbarton Rail, show relatively lower additions without purposeful additions of activity centers. The most critical factor to accessibility as measured in this paper is the presence of activity centers along lines. Providing connections is also important, if well located, and providing clear travel time benefit. While it can be seen which extensions in the region have an inherent accessibility benefit and which have lower benefit, it is important to remember that accessibility does not guarantee successful transit-oriented development. Ultimately success and failure are dependent on decisions made on how to develop station areas. 


\section{APPENDICES}

\section{Appendices to Chapter 2}

Table X2.1

Energy Use By Sector, 1949-2007 (Billions of BTUs)

\begin{tabular}{|c|c|c|c|c|}
\hline Year & Residential & Commercial & Industrial & Transportation \\
\hline 1949 & 5.6 & 3.7 & 14.7 & 8.0 \\
\hline 1950 & 6.0 & 3.9 & 16.2 & 8.5 \\
\hline 1951 & 6.4 & 3.9 & 17.7 & 9.0 \\
\hline 1952 & 6.6 & 3.9 & 17.3 & 9.0 \\
\hline 1953 & 6.6 & 3.8 & 18.2 & 9.1 \\
\hline 1954 & 6.9 & 3.7 & 17.1 & 8.9 \\
\hline 1955 & 7.3 & 3.9 & 19.5 & 9.6 \\
\hline 1956 & 7.7 & 4.0 & 20.2 & 9.9 \\
\hline 1957 & 7.7 & 3.9 & 20.2 & 9.9 \\
\hline 1958 & 8.2 & 4.1 & 19.3 & 10.0 \\
\hline 1959 & 8.4 & 4.4 & 20.3 & 10.3 \\
\hline 1960 & 9.1 & 4.6 & 20.8 & 10.6 \\
\hline 1961 & 9.3 & 4.7 & 20.9 & 10.8 \\
\hline 1962 & 9.8 & 5.0 & 21.8 & 11.2 \\
\hline 1963 & 10.0 & 5.2 & 22.7 & 11.7 \\
\hline 1964 & 10.3 & 5.4 & 24.1 & 12.0 \\
\hline 1965 & 10.7 & 5.8 & 25.1 & 12.4 \\
\hline 1966 & 11.2 & 6.3 & 26.4 & 13.1 \\
\hline 1967 & 11.7 & 6.9 & 26.6 & 13.8 \\
\hline 1968 & 12.4 & 7.3 & 27.9 & 14.9 \\
\hline 1969 & 13.2 & 7.8 & 29.1 & 15.5 \\
\hline 1970 & 13.8 & 8.3 & 29.6 & 16.1 \\
\hline 1971 & 14.3 & 8.7 & 29.6 & 16.7 \\
\hline 1972 & 14.9 & 9.1 & 31.0 & 17.7 \\
\hline 1973 & 14.9 & 9.5 & 32.7 & 18.6 \\
\hline 1974 & 14.7 & 9.4 & 31.8 & 18.1 \\
\hline 1975 & 14.8 & 9.5 & 29.4 & 18.2 \\
\hline 1976 & 15.4 & 10.0 & 31.4 & 19.1 \\
\hline 1977 & 15.7 & 10.2 & 32.3 & 19.8 \\
\hline 1978 & 16.2 & 10.5 & 32.7 & 20.6 \\
\hline 1979 & 15.8 & 10.6 & 34.0 & 20.5 \\
\hline 1980 & 15.8 & 10.6 & 32.1 & 19.7 \\
\hline 1981 & 15.3 & 10.6 & 30.8 & 19.5 \\
\hline
\end{tabular}




\begin{tabular}{|c|c|c|c|c|}
\hline Year & Residential & Commercial & Industrial & Transportation \\
\hline 1982 & 15.6 & 10.8 & 27.7 & 19.1 \\
\hline 1983 & 15.5 & 10.9 & 27.5 & 19.2 \\
\hline 1984 & 15.9 & 11.5 & 29.6 & 19.7 \\
\hline 1985 & 16.1 & 11.4 & 28.9 & 20.1 \\
\hline 1986 & 16.0 & 11.6 & 28.3 & 20.8 \\
\hline 1987 & 16.3 & 11.9 & 29.4 & 21.5 \\
\hline 1988 & 17.2 & 12.6 & 30.7 & 22.3 \\
\hline 1989 & 17.9 & 13.2 & 31.4 & 22.5 \\
\hline 1990 & 17.0 & 13.3 & 31.9 & 22.4 \\
\hline 1991 & 17.5 & 13.5 & 31.5 & 22.1 \\
\hline 1992 & 17.4 & 13.5 & 32.7 & 22.4 \\
\hline 1993 & 18.3 & 13.8 & 32.7 & 22.8 \\
\hline 1994 & 18.2 & 14.1 & 33.6 & 23.4 \\
\hline 1995 & 18.6 & 14.7 & 34.0 & 23.8 \\
\hline 1996 & 19.6 & 15.2 & 35.0 & 24.4 \\
\hline 1997 & 19.0 & 15.7 & 35.3 & 24.8 \\
\hline 1998 & 19.0 & 16.0 & 34.9 & 25.3 \\
\hline 1999 & 19.6 & 16.4 & 34.9 & 26.0 \\
\hline 2000 & 20.5 & 17.2 & 34.8 & 26.6 \\
\hline 2001 & 20.1 & 17.1 & 32.8 & 26.3 \\
\hline 2002 & 20.9 & 17.4 & 32.8 & 26.8 \\
\hline 2003 & 21.2 & 17.4 & 32.7 & 27.0 \\
\hline 2004 & 21.2 & 17.7 & 33.6 & 27.9 \\
\hline 2005 & 21.7 & 17.9 & 32.5 & 28.4 \\
\hline 2006 & 20.9 & 17.7 & 32.4 & 28.9 \\
\hline 2007 & 21.8 & 18.4 & 32.3 & 29.1 \\
\hline
\end{tabular}

Source: Energy Information Administration (2007), Annual Energy Review, Table 2.1a 
Table X2.2

Energy Intensity by Passenger Mode (in BTU per Passenger Miles Traveled), 1994-2006

\begin{tabular}{|c|c|c|c|c|c|c|c|c|}
\hline & $\begin{array}{r}\text { Domestic } \\
\text { Aircraft }^{1}\end{array}$ & $\begin{array}{r}\text { Light-duty } \\
\text { trucks }^{1}\end{array}$ & $\begin{array}{c}\text { Transit } \\
\text { Buses }^{1}\end{array}$ & $\begin{array}{r}\text { Passenger } \\
\text { cars }^{1}\end{array}$ & Amtrak $^{1}$ & $\begin{array}{r}\text { Commuter } \\
\text { Rail }^{2}\end{array}$ & \begin{tabular}{r|} 
Light \\
Rail $^{2}$
\end{tabular} & $\begin{array}{r}\text { Heavy } \\
\text { Rail }^{2}\end{array}$ \\
\hline 1994 & 4,444 & 4,345 & 4,162 & 3,771 & 1,935 & -- & -- & -- \\
\hline 1995 & 4,382 & 4,538 & 4,155 & 3,721 & 1,838 & 1,580 & 1,143 & 1,099 \\
\hline 1996 & 4,183 & 4,541 & 4,196 & 3,688 & 2,153 & 1,541 & 1,144 & 986 \\
\hline 1997 & 4,166 & 4,564 & 4,228 & 3,657 & 2,200 & 1,630 & 1,190 & 921 \\
\hline 1998 & 4,123 & 4,569 & 4,133 & 3,637 & 2,138 & 1,612 & 1,152 & 911 \\
\hline 1999 & 4,049 & 4,612 & 4,044 & 3,672 & 2,107 & 1,670 & 1,177 & 895 \\
\hline 2000 & 3,883 & 4,509 & 4,147 & 3,589 & 2,134 & 1,542 & 1,165 & 875 \\
\hline 2001 & 3,890 & 3,985 & 3,698 & 3,597 & 2,100 & 1,533 & 1,156 & 877 \\
\hline 2002 & 3,596 & 4,121 & 3,550 & 3,600 & -- & 1,541 & 1,215 & 920 \\
\hline 2003 & 3,463 & 4,452 & 3,496 & 3,570 & -- & 1,543 & 1,172 & 911 \\
\hline 2004 & 3,297 & 4,452 & -- & 3,527 & -- & 1,536 & 1,197 & 876 \\
\hline 2005 & -- & -- & -- & -- & -- & 1,658 & 1,146 & 892 \\
\hline 2006 & -- & -- & -- & -- & -- & 1,539 & 1,159 & 860 \\
\hline
\end{tabular}

1 - Source: Bureau of Transportation Statistics (2006), National Transporation Statistics, Table K-6

2 - Calculation based on passenger, fuel, and energy consumption figues from the American Public

Transportation Association (2007), Public Transportation Fact Book, Tables 6, 27, 28

Table X2.3

Calculation of Energy Intensity for Heavy Rail and Light Rail

\begin{tabular}{|c|r|r|r|r|r|r|}
\hline & \multicolumn{2}{|c|}{$\begin{array}{c}\text { Electric power } \\
\text { consumption (Trillions of } \\
\text { BTU) }\end{array}$} & $\begin{array}{r}\text { Passenger Miles Traveled } \\
\text { (Billions of Miles) }\end{array}$ & \multicolumn{2}{|c|}{$\begin{array}{c}\text { Energy Intensity } \\
\text { (BTU/Mile Traveled) }\end{array}$} \\
\cline { 2 - 7 } & $\begin{array}{r}\text { Heavy Rail } \\
\text { (BT Light Rail }\end{array}$ & Heavy Rail & Light Rail & Heavy Rail & Light Rail \\
\hline $\mathbf{1 9 9 5}$ & 11.60 & 0.98 & 10.56 & 0.86 & 1099.0 & 1142.6 \\
\hline $\mathbf{1 9 9 6}$ & 11.37 & 1.10 & 11.53 & 0.96 & 986.0 & 1144.5 \\
\hline $\mathbf{1 9 9 7}$ & 11.10 & 1.23 & 12.06 & 1.04 & 920.6 & 1190.1 \\
\hline $\mathbf{1 9 9 8}$ & 11.19 & 1.30 & 12.28 & 1.13 & 911.1 & 1152.5 \\
\hline $\mathbf{1 9 9 9}$ & 11.55 & 1.42 & 12.90 & 1.21 & 895.2 & 1176.9 \\
\hline $\mathbf{2 0 0 0}$ & 12.11 & 1.58 & 13.84 & 1.36 & 874.7 & 1165.0 \\
\hline $\mathbf{2 0 0 1}$ & 12.44 & 1.66 & 14.18 & 1.44 & 877.4 & 1156.3 \\
\hline $\mathbf{2 0 0 2}$ & 12.57 & 1.74 & 13.66 & 1.43 & 919.7 & 1215.2 \\
\hline $\mathbf{2 0 0 3}$ & 12.39 & 1.73 & 13.61 & 1.48 & 910.8 & 1172.0 \\
\hline $\mathbf{2 0 0 4}$ & 12.57 & 1.89 & 14.35 & 1.58 & 875.7 & 1197.2 \\
\hline $\mathbf{2 0 0 5}$ & 12.86 & 1.95 & 14.42 & 1.70 & 891.9 & 1146.0 \\
\hline $\mathbf{2 0 0 6 *}$ & 12.66 & 2.16 & 14.72 & 1.87 & 859.7 & 1159.3 \\
\hline
\end{tabular}

*Preliminary figure

Source: American Public Transportation Association (2007), Public Transportation Fact Book, Tables 6 and 27 
Table X2.4

Calculation of Energy Intensity for Commuter Rail

\begin{tabular}{|c|c|c|c|c|c|c|}
\hline \multirow{2}{*}{ FY } & \multirow{2}{*}{$\begin{array}{r}\text { Diesel fuel } \\
\text { used } \\
\text { (Millions of } \\
\text { gallons) }\end{array}$} & \multicolumn{3}{|c|}{ Energy Used (Trillions of BTUs) } & \multirow{2}{*}{$\begin{array}{r}\text { Passenger. } \\
\text { Miles Trvld. } \\
\text { (Billions of } \\
\text { Miles) }\end{array}$} & \multirow{2}{*}{$\begin{array}{r}\text { Energ } \\
\text { Intensit } \\
\text { (BTU/Mile } \\
\text { Traveled }\end{array}$} \\
\hline & & Diesel & Electric & Total & & \\
\hline 1995 & 63.1 & 8.75 & 4.28 & 13.03 & 8.24 & 1580.2 \\
\hline 1996 & 61.9 & 8.59 & 4.28 & 12.87 & 8.35 & 1540.8 \\
\hline 1997 & 63.2 & 8.77 & 4.33 & 13.10 & 8.04 & 1629.6 \\
\hline 1998 & 69.2 & 9.60 & 4.43 & 14.03 & 8.70 & 1611.9 \\
\hline 1999 & 73.0 & 10.13 & 4.51 & 14.64 & 8.77 & 1669.6 \\
\hline 2000 & 70.8 & 9.82 & 4.67 & 14.49 & 9.40 & 1541.6 \\
\hline 2001 & 72.2 & 10.01 & 4.62 & 14.63 & 9.55 & 1532.7 \\
\hline 2002 & 72.8 & 10.10 & 4.55 & 14.65 & 9.50 & 1541.3 \\
\hline 2003 & 72.3 & 10.03 & 4.72 & 14.75 & 9.56 & 1542.7 \\
\hline 2004 & 72.0 & 9.99 & 4.94 & 14.93 & 9.72 & 1536.2 \\
\hline 2005 & 76.7 & 10.64 & 5.06 & 15.70 & 9.47 & 1657.5 \\
\hline $2006 *$ & 78.6 & 10.90 & 5.04 & 15.94 & 10.36 & 1538.9 \\
\hline
\end{tabular}

*Preliminary figure 
Table X2.5

Carbon Dioxide Emissions by Economic Sector (Millions of Metric Tons of $\mathrm{CO}_{2}$ ), 19802006

\begin{tabular}{|r|r|r|r|r|r|}
\hline Year & Transportation & Industrial & Residential & Commercial & Total \\
\hline $\mathbf{1 9 8 0}$ & 1,386 & 1,788 & 909 & 653 & 4,735 \\
\hline $\mathbf{1 9 8 1}$ & 1,372 & 1,714 & 878 & 652 & 4,616 \\
\hline $\mathbf{1 9 8 2}$ & 1,341 & 1,507 & 872 & 654 & 4,374 \\
\hline $\mathbf{1 9 8 3}$ & 1,345 & 1,467 & 866 & 661 & 4,339 \\
\hline $\mathbf{1 9 8 4}$ & 1,390 & 1,613 & 886 & 694 & 4,582 \\
\hline $\mathbf{1 9 8 5}$ & 1,409 & 1,568 & 900 & 694 & 4,570 \\
\hline $\mathbf{1 9 8 6}$ & 1,463 & 1,523 & 895 & 699 & 4,580 \\
\hline $\mathbf{1 9 8 7}$ & 1,507 & 1,586 & 922 & 725 & 4,739 \\
\hline $\mathbf{1 9 8 8}$ & 1,567 & 1,659 & 970 & 760 & 4,956 \\
\hline $\mathbf{1 9 8 9}$ & 1,584 & 1,682 & 995 & 789 & 5,050 \\
\hline $\mathbf{1 9 9 0}$ & 1,583 & 1,680 & 962 & 788 & 5,012 \\
\hline $\mathbf{1 9 9 1}$ & 1,561 & 1,638 & 977 & 788 & 4,965 \\
\hline $\mathbf{1 9 9 2}$ & 1,582 & 1,712 & 979 & 790 & 5,063 \\
\hline $\mathbf{1 9 9 3}$ & 1,611 & 1,703 & 1,039 & 816 & 5,168 \\
\hline $\mathbf{1 9 9 4}$ & 1,652 & 1,732 & 1,032 & 830 & 5,246 \\
\hline $\mathbf{1 9 9 5}$ & 1,682 & 1,731 & 1,039 & 848 & 5,301 \\
\hline $\mathbf{1 9 9 6}$ & 1,725 & 1,785 & 1,098 & 879 & 5,488 \\
\hline $\mathbf{1 9 9 7}$ & 1,744 & 1,812 & 1,090 & 923 & 5,569 \\
\hline $\mathbf{1 9 9 8}$ & 1,780 & 1,786 & 1,097 & 944 & 5,606 \\
\hline $\mathbf{1 9 9 9}$ & 1,828 & 1,765 & 1,120 & 956 & 5,669 \\
\hline $\mathbf{2 0 0 0}$ & 1,873 & 1,778 & 1,182 & 1,015 & 5,847 \\
\hline $\mathbf{2 0 0 1}$ & 1,851 & 1,704 & 1,171 & 1,023 & 5,749 \\
\hline $\mathbf{2 0 0 2}$ & 1,891 & 1,708 & 1,196 & 1,018 & 5,813 \\
\hline $\mathbf{2 0 0 3}$ & 1,901 & 1,713 & 1,224 & 1,027 & 5,866 \\
\hline $\mathbf{2 0 0 4}$ & 1,959 & 1,736 & 1,222 & 1,042 & 5,957 \\
\hline $\mathbf{2 0 0 5}$ & 1,986 & 1,677 & 1,253 & 1,065 & 5,982 \\
\hline $\mathbf{2 0 0 6}$ & 1,990 & 1,651 & 1,204 & 1,045 & 5,890 \\
\hline
\end{tabular}

Source: Energy Information Administration (2007), Annual Energy Review, Table 12.2 
Table X2.6

Calculation of relative carbon content of different energy fuels

\begin{tabular}{|c|c|c|c|c|}
\hline Fuel & $\begin{array}{c}\text { Given Energy } \\
\text { Production per Unit } \\
\text { Fuel }\end{array}$ & $\begin{array}{c}\text { Given Carbon } \\
\text { Content per Unit } \\
\text { Fuel }\end{array}$ & $\begin{array}{c}\text { Calculated or Given } \\
\text { Carbon per Unit } \\
\text { Energy }\end{array}$ & $\begin{array}{c}\text { Carbon Content per } \\
\text { Unit Energy } \\
\text { (Converted) }\end{array}$ \\
\hline Coal & -- & -- & $\begin{array}{c}25.4 \text { metric tons/ } \\
\text { terajoule }\end{array}$ & $25.4 \mathrm{~g} / \mathrm{megajoule}$ \\
\hline $\begin{array}{c}\text { Oil } \\
\text { (average) }\end{array}$ & -- & -- & $\begin{array}{c}19.9 \text { metric tons/ } \\
\text { terajoule }\end{array}$ & 19.9 g/megajoule \\
\hline \multirow[b]{2}{*}{ Gasoline } & 115,000 BTU/gallon & \multirow[b]{2}{*}{$2.42 \mathrm{~kg} /$ gallon } & \multirow{2}{*}{$\begin{array}{c}2.42 \mathrm{~kg} / \\
121.325 \text { megajoules }\end{array}$} & \multirow[b]{2}{*}{19.9 g/megajoule } \\
\hline & $\begin{array}{c}121.325 \text { megajoules/ } \\
\text { gallon }\end{array}$ & & & \\
\hline \multirow{2}{*}{$\begin{array}{l}\text { Petro- } \\
\text { Diesel }\end{array}$} & 130,500 BTU/gallon & \multirow[b]{2}{*}{2.77 kg/gallon } & \multirow{2}{*}{$\begin{array}{c}2.77 \mathrm{~kg} / \\
131.676 \text { megajoules }\end{array}$} & \multirow[b]{2}{*}{$20.1 \mathrm{~g} / \mathrm{megajoule}$} \\
\hline & $\begin{array}{c}137.676 \text { megajoules/ } \\
\text { gallon }\end{array}$ & & & \\
\hline $\begin{array}{l}\text { Natural } \\
\text { Gas }\end{array}$ & $\begin{array}{c}34.6 \text { megajoules/ } \\
\text { cubic meter }\end{array}$ & $.49 \mathrm{~kg} / \mathrm{cubic}$ meter & $\begin{array}{c}.49 \mathrm{~kg} / \\
34.6 \text { megajoules }\end{array}$ & 14.2 g/megajoule \\
\hline
\end{tabular}

Conversion Factors:

1 terajoule $=1,000,000$ megajoules

1 megajoule $=1,000,000$ joules

$1 \mathrm{BTU}=1,055$ joules

1 metric ton $=1,000 \mathrm{~kg}$

$1 \mathrm{~kg}=1,000 \mathrm{~g}$

Source: Oak Ridge National Laboratory, Bioenergy Conversion Factors 
Table X2.7

Real Gas Prices (in 2008 Dollars), 1919-2010

\begin{tabular}{|c|c|c|c|c|c|c|c|}
\hline Year & $\begin{array}{r}\text { Nominal } \\
\text { Retail Gas. } \\
\text { Price } \\
\text { (\$/Gallon) }\end{array}$ & $\begin{array}{r}\text { Consumer } \\
\text { Price } \\
\text { Index } \\
(2008=1) \\
\end{array}$ & $\begin{array}{r}\text { Real } \\
\text { Gasoline } \\
\text { Price } \\
\text { (\$/Gallon) }\end{array}$ & Year & $\begin{array}{r}\text { Nominal } \\
\text { Retail } \\
\text { Gas.Price } \\
\text { (\$/Gallon) } \\
\end{array}$ & $\begin{array}{r}\text { Consumer } \\
\text { Price } \\
\text { Index } \\
(2008=1) \\
\end{array}$ & $\begin{array}{r}\text { Real } \\
\text { Gasoline } \\
\text { Price } \\
\text { (\$/Gallon) } \\
\end{array}$ \\
\hline 1919 & $\$ 0.25$ & 0.080 & $\$ 3.17$ & 1954 & $\$ 0.29$ & 0.125 & $\$ 2.33$ \\
\hline 1920 & $\$ 0.30$ & 0.093 & $\$ 3.21$ & 1955 & $\$ 0.29$ & 0.124 & $\$ 2.34$ \\
\hline 1921 & $\$ 0.26$ & 0.083 & $\$ 3.16$ & 1956 & $\$ 0.30$ & 0.126 & $\$ 2.37$ \\
\hline 1922 & $\$ 0.25$ & 0.078 & $\$ 3.24$ & 1957 & $\$ 0.31$ & 0.131 & $\$ 2.37$ \\
\hline 1923 & $\$ 0.22$ & 0.079 & $\$ 2.77$ & 1958 & $\$ 0.30$ & 0.134 & $\$ 2.26$ \\
\hline 1924 & $\$ 0.21$ & 0.079 & $\$ 2.64$ & 1959 & $\$ 0.31$ & 0.135 & $\$ 2.26$ \\
\hline 1925 & $\$ 0.22$ & 0.081 & $\$ 2.73$ & 1960 & $\$ 0.31$ & 0.138 & $\$ 2.26$ \\
\hline 1926 & $\$ 0.23$ & 0.082 & $\$ 2.84$ & 1961 & $\$ 0.31$ & 0.139 & $\$ 2.21$ \\
\hline 1927 & $\$ 0.21$ & 0.081 & $\$ 2.61$ & 1962 & $\$ 0.31$ & 0.140 & $\$ 2.18$ \\
\hline 1928 & $\$ 0.21$ & 0.080 & $\$ 2.63$ & 1963 & $\$ 0.30$ & 0.142 & $\$ 2.14$ \\
\hline 1929 & $\$ 0.21$ & 0.080 & $\$ 2.69$ & 1964 & $\$ 0.30$ & 0.144 & $\$ 2.11$ \\
\hline 1930 & $\$ 0.20$ & 0.078 & $\$ 2.57$ & 1965 & $\$ 0.31$ & 0.146 & $\$ 2.13$ \\
\hline 1931 & $\$ 0.17$ & 0.071 & $\$ 2.40$ & 1966 & $\$ 0.32$ & 0.151 & $\$ 2.13$ \\
\hline 1932 & $\$ 0.18$ & 0.063 & $\$ 2.83$ & 1967 & $\$ 0.33$ & 0.155 & $\$ 2.14$ \\
\hline 1933 & $\$ 0.18$ & 0.060 & $\$ 2.96$ & 1968 & $\$ 0.34$ & 0.162 & $\$ 2.08$ \\
\hline 1934 & $\$ 0.19$ & 0.062 & $\$ 3.03$ & 1969 & $\$ 0.35$ & 0.171 & $\$ 2.04$ \\
\hline 1935 & $\$ 0.19$ & 0.064 & $\$ 2.96$ & 1970 & $\$ 0.36$ & 0.180 & $\$ 1.98$ \\
\hline 1936 & $\$ 0.19$ & 0.064 & $\$ 3.02$ & 1971 & $\$ 0.36$ & 0.188 & $\$ 1.94$ \\
\hline 1937 & $\$ 0.20$ & 0.067 & $\$ 3.00$ & 1972 & $\$ 0.36$ & 0.174 & $\$ 2.08$ \\
\hline 1938 & $\$ 0.20$ & 0.065 & $\$ 2.98$ & 1973 & $\$ 0.39$ & 0.206 & $\$ 1.88$ \\
\hline 1939 & $\$ 0.19$ & 0.065 & $\$ 2.91$ & 1974 & $\$ 0.52$ & 0.229 & $\$ 2.29$ \\
\hline 1940 & $\$ 0.18$ & 0.065 & $\$ 2.83$ & 1975 & $\$ 0.57$ & 0.250 & $\$ 2.29$ \\
\hline 1941 & $\$ 0.19$ & 0.068 & $\$ 2.81$ & 1976 & $\$ 0.59$ & 0.264 & $\$ 2.25$ \\
\hline 1942 & $\$ 0.20$ & 0.076 & $\$ 2.70$ & 1977 & $\$ 0.62$ & 0.282 & $\$ 2.20$ \\
\hline 1943 & $\$ 0.21$ & 0.080 & $\$ 2.55$ & 1978 & $\$ 0.63$ & 0.303 & $\$ 2.08$ \\
\hline 1944 & $\$ 0.21$ & 0.082 & $\$ 2.52$ & 1979 & $\$ 0.86$ & 0.337 & $\$ 2.55$ \\
\hline 1945 & $\$ 0.21$ & 0.084 & $\$ 2.45$ & 1980 & $\$ 1.25$ & 0.383 & $\$ 3.25$ \\
\hline 1946 & $\$ 0.21$ & 0.091 & $\$ 2.29$ & 1981 & $\$ 1.38$ & 0.422 & $\$ 3.26$ \\
\hline 1947 & $\$ 0.23$ & 0.104 & $\$ 2.23$ & 1982 & $\$ 1.26$ & 0.448 & $\$ 2.81$ \\
\hline 1948 & $\$ 0.26$ & 0.112 & $\$ 2.31$ & 1983 & $\$ 1.20$ & 0.463 & $\$ 2.60$ \\
\hline 1949 & $\$ 0.27$ & 0.111 & $\$ 2.42$ & 1984 & $\$ 1.18$ & 0.483 & $\$ 2.44$ \\
\hline 1950 & $\$ 0.27$ & 0.112 & $\$ 2.39$ & 1985 & $\$ 1.17$ & 0.500 & $\$ 2.33$ \\
\hline 1951 & $\$ 0.27$ & 0.121 & $\$ 2.25$ & 1986 & $\$ 0.89$ & 0.510 & $\$ 1.75$ \\
\hline 1952 & $\$ 0.28$ & 0.123 & $\$ 2.23$ & 1987 & $\$ 0.91$ & 0.528 & $\$ 1.73$ \\
\hline 1953 & $\$ 0.29$ & 0.124 & $\$ 2.31$ & 1988 & $\$ 0.91$ & 0.550 & $\$ 1.65$ \\
\hline
\end{tabular}




\begin{tabular}{|l|r|r|r|r|r|r|r|}
\hline Year & $\begin{array}{r}\text { Nominal } \\
\text { Retail Gas. } \\
\text { Price } \\
\text { (\$/Gallon) }\end{array}$ & $\begin{array}{r}\text { Consumer } \\
\text { Price } \\
\text { Index } \\
(\mathbf{2 0 0 8}=1)\end{array}$ & $\begin{array}{r}\text { Real } \\
\text { Gasoline } \\
\text { Price } \\
\text { (\$/Gallon) }\end{array}$ & Year & $\begin{array}{r}\text { Nominal } \\
\text { Retail Gas. } \\
\text { Price } \\
\text { (\$/Gallon) }\end{array}$ & $\begin{array}{r}\text { Consumer } \\
\text { Price } \\
\text { Index } \\
(2008=1)\end{array}$ & $\begin{array}{r}\text { Real } \\
\text { Gasoline } \\
\text { Price } \\
\text { (\$/Gallon) }\end{array}$ \\
\hline 1989 & $\$ 0.98$ & 0.576 & $\$ 1.71$ & 2000 & $\$ 1.49$ & 0.800 & $\$ 1.86$ \\
\hline 1990 & $\$ 1.13$ & 0.607 & $\$ 1.86$ & $\mathbf{2 0 0 1}$ & $\$ 1.43$ & 0.823 & $\$ 1.73$ \\
\hline 1991 & $\$ 1.10$ & 0.633 & $\$ 1.74$ & 2002 & $\$ 1.34$ & 0.836 & $\$ 1.60$ \\
\hline 1992 & $\$ 1.09$ & 0.652 & $\$ 1.67$ & 2003 & $\$ 1.56$ & 0.855 & $\$ 1.82$ \\
\hline 1993 & $\$ 1.07$ & 0.670 & $\$ 1.59$ & 2004 & $\$ 1.85$ & 0.878 & $\$ 2.11$ \\
\hline 1994 & $\$ 1.07$ & 0.689 & $\$ 1.56$ & $\mathbf{2 0 0 5}$ & $\$ 2.27$ & 0.907 & $\$ 2.50$ \\
\hline 1995 & $\$ 1.11$ & 0.709 & $\$ 1.57$ & $\mathbf{2 0 0 6}$ & $\$ 2.58$ & 0.937 & $\$ 2.75$ \\
\hline 1996 & $\$ 1.20$ & 0.729 & $\$ 1.64$ & $\mathbf{2 0 0 7}$ & $\$ 2.81$ & 0.963 & $\$ 2.91$ \\
\hline 1997 & $\$ 1.20$ & 0.746 & $\$ 1.61$ & $\mathbf{2 0 0 8}$ & $\$ 3.26$ & 1.000 & $\$ 3.26$ \\
\hline 1998 & $\$ 1.03$ & 0.758 & $\$ 1.36$ & $\mathbf{2 0 0 9}$ & $\$ 2.33$ & 0.992 & $\$ 2.35$ \\
\hline 1999 & $\$ 1.14$ & 0.775 & $\$ 1.47$ & $\mathbf{2 0 1 0}$ & $\$ 2.56$ & 1.011 & $\$ 2.54$ \\
\hline
\end{tabular}

*Projection for 2010

Source: Energy Information Administration (2009), Short-Term Energy Outlook, Real Petroleum Prices 
Table X2.8

Real Gas Prices (in 2008 Dollars) and Vehicle Miles Traveled, January 2007 - April 2009

\begin{tabular}{|c|c|c|}
\hline Month & $\begin{array}{l}\text { Real Gas Price } \\
\text { (2008 Dollars) }\end{array}$ & $\begin{array}{r}\text { Vehicle Miles } \\
\text { Traveled } \\
\text { (Trillions of Miles) }\end{array}$ \\
\hline January 2007 & $\$ 2.34$ & 3.015 \\
\hline February 2007 & $\$ 2.37$ & 3.013 \\
\hline March 2007 & $\$ 2.66$ & 3.016 \\
\hline April 2007 & $\$ 2.94$ & 3.018 \\
\hline May 2007 & $\$ 3.24$ & 3.022 \\
\hline June 2007 & $\$ 3.14$ & 3.024 \\
\hline July 2007 & $\$ 3.05$ & 3.028 \\
\hline August 2007 & $\$ 2.86$ & 3.034 \\
\hline September 2007 & $\$ 2.86$ & 3.034 \\
\hline October 2007 & $\$ 2.84$ & 3.037 \\
\hline November 2007 & $\$ 3.11$ & 3.038 \\
\hline December 2007 & $\$ 3.04$ & 3.030 \\
\hline January 2008 & $\$ 3.05$ & 3.026 \\
\hline February 2008 & $\$ 3.03$ & 3.024 \\
\hline March 2008 & $\$ 3.23$ & 3.013 \\
\hline April 2008 & $\$ 3.43$ & 3.009 \\
\hline May 2008 & $\$ 3.72$ & 2.999 \\
\hline June 2008 & $\$ 3.99$ & 2.985 \\
\hline July 2008 & $\$ 3.95$ & 2.976 \\
\hline August 2008 & $\$ 3.67$ & 2.961 \\
\hline September 2008 & $\$ 3.61$ & 2.950 \\
\hline October 2008 & $\$ 3.02$ & 2.941 \\
\hline November 2008 & $\$ 2.14$ & 2.928 \\
\hline December 2008 & $\$ 1.69$ & 2.926 \\
\hline January 2009 & $\$ 1.79$ & 2.919 \\
\hline February 2009 & $\$ 1.93$ & 2.917 \\
\hline March 2009 & $\$ 1.96$ & 2.914 \\
\hline April 2009 & $\$ 2.05$ & 2.915 \\
\hline
\end{tabular}

Source: Energy Information Administration (2009), Short-Term Energy Outlook, Real Petroleum Prices;

Federal Highway Administration (2009), Traffic Volume Trends, Figure 1 


\section{Appendices to Chapter 3}

Table X3.1

Job Counts Within One Quarter and One Half Mile of Existing or Potential Rail Stations, 2006

\begin{tabular}{|c|c|c|c|c|c|c|c|}
\hline Station & $\begin{array}{r}\text { Jobs } \\
\text { W/in } \\
.25 \\
\text { Miles }\end{array}$ & $\begin{array}{c}\text { Jobs } \\
\text { W/in } \\
\text { Half } \\
\text { Mile }\end{array}$ & $\begin{array}{r}\text { Jobs } \\
\text { Within } \\
1 \text { Mile }\end{array}$ & Station & $\begin{array}{r}\text { Jobs } \\
\text { W/in } \\
.25 \\
\text { Miles }\end{array}$ & $\begin{array}{c}\text { Jobs } \\
\text { W/in } \\
\text { Half } \\
\text { Mile }\end{array}$ & $\begin{array}{r}\text { Jobs } \\
\text { Within } \\
1 \text { Mile }\end{array}$ \\
\hline $\begin{array}{l}\text { 12th St- } \\
\text { Oakland }\end{array}$ & 20,435 & 46,388 & 70,520 & Diridon & 2,668 & 9,737 & 46,618 \\
\hline $\begin{array}{l}\text { 16th St- } \\
\text { Mission }\end{array}$ & 3,660 & 45,137 & 91,518 & Dublin/Pleasanton & 70 & 3,201 & 25,684 \\
\hline $\begin{array}{l}\text { 19th St- } \\
\text { Oakland }\end{array}$ & 14,856 & 37,994 & 73,860 & $\begin{array}{l}\text { El Cerrito del } \\
\text { Norte }\end{array}$ & 588 & 1,556 & 3,282 \\
\hline $\begin{array}{l}\text { 24th St- } \\
\text { Mission }\end{array}$ & 2,317 & 6,181 & 19,972 & El Cerrito Plaza & 1,261 & 2,582 & 6,194 \\
\hline 4th and King & 3,250 & 18,574 & 98,363 & Embarcadero & 6,915 & 31,785 & 185,457 \\
\hline Alum Rock & 531 & 1,706 & 5,699 & Fremont & 3,442 & 8,627 & 18,030 \\
\hline $\begin{array}{l}\text { Antioch } \\
\text { Fairgrds. }\end{array}$ & 88 & 1,108 & 4,865 & Fruitvale & 1,171 & 4,326 & 10,165 \\
\hline Ashby & 828 & 2,706 & 13,251 & Gilroy & 300 & 1,395 & 6,101 \\
\hline Atherton & 90 & 1,051 & 3,676 & Glenn Park & 310 & 1,603 & 4,130 \\
\hline Balboa Park & 2,671 & 3,591 & 6,751 & Hayward & 774 & 2,769 & 11,971 \\
\hline Bayfair & 1,213 & 1,771 & 6,314 & Hayward Park & 648 & 4,400 & 16,132 \\
\hline Bayshore & 107 & 1,893 & 3,305 & Hillcrest Avenue & 87 & 425 & 1,704 \\
\hline Belmont & 1,383 & 3,522 & 13,812 & Hillsdale & 534 & 3,674 & 9,850 \\
\hline Berkeley & 10,343 & 32,470 & 39,587 & Irvington & 445 & 1,726 & 4,394 \\
\hline Berryessa & 327 & 1,697 & 7,683 & Lafayette & 811 & 3,003 & 5,909 \\
\hline Blossom Hill & 624 & 4,384 & 11,110 & Lake Merritt & 7,088 & 30,202 & 68,117 \\
\hline Brentwood & 1,443 & 2,041 & 4,844 & Lawrence & 2,984 & 7,418 & 20,097 \\
\hline Broadway & 933 & 6,338 & 13,379 & MacArthur & 257 & 2,241 & 25,365 \\
\hline Burlingame & 2,524 & 4,436 & 11,147 & $\begin{array}{c}\text { Market St-San } \\
\text { Jose }\end{array}$ & 25,877 & 35,553 & 45,376 \\
\hline Byron & 4 & 412 & 451 & Menlo Park & 4,610 & 8,293 & 11,072 \\
\hline $\begin{array}{l}\text { California } \\
\text { Avenue }\end{array}$ & 2,346 & 7,532 & 13,724 & Millbrae & 737 & 3,648 & 24,691 \\
\hline Capitol & 117 & 1,269 & 5,630 & Montague & 1,574 & 8,985 & 20,711 \\
\hline Castro Valley & 502 & 2,570 & 10,228 & Montgomery & 64,162 & 159,034 & 246,163 \\
\hline Centerville & 767 & 1,251 & 3,433 & Morgan Hill & 586 & 2,571 & 4,343 \\
\hline Civic Center & 10,066 & 37,936 & 161,010 & Mountain View & 2,003 & 4,860 & 11,902 \\
\hline Civic Ctr/SJSU & 1,375 & 26,284 & 38,742 & Newark & 1,806 & 2,163 & 2,746 \\
\hline
\end{tabular}




\begin{tabular}{|c|c|c|c|c|c|c|c|}
\hline Station & $\begin{array}{r}\text { Jobs } \\
\text { Within } \\
.25 \\
\text { Miles }\end{array}$ & $\begin{array}{r}\text { Jobs } \\
\text { Within } \\
\text { Half } \\
\text { Mile }\end{array}$ & $\begin{array}{r}\text { Jobs } \\
\text { Within } \\
1 \text { Mile }\end{array}$ & Station & $\begin{array}{r}\text { Jobs } \\
\text { Within } \\
.25 \\
\text { Miles }\end{array}$ & $\begin{array}{r}\text { Jobs } \\
\text { Within } \\
\text { Half } \\
\text { Mile }\end{array}$ & $\begin{array}{r}\text { Jobs } \\
\text { Within } \\
1 \text { Mile }\end{array}$ \\
\hline $\begin{array}{c}\text { Coliseum/OAK } \\
\text { Apt }\end{array}$ & 525 & 6,366 & 13,147 & North Berkeley & 72 & 1,451 & 20,715 \\
\hline College Park & 584 & 4,370 & 17,049 & North Concord & 103 & 117 & 7,451 \\
\hline Colma & 894 & 4,737 & 11,784 & Oakley & 0 & 192 & 1,861 \\
\hline Concord & 25 & 8,245 & 18,527 & Orinda & 756 & 1,511 & 2,400 \\
\hline Daly City & 401 & 2,002 & 7,469 & Palo Alto & 4,084 & 15,562 & 41,567 \\
\hline Pittsburg & 86 & 132 & 683 & SFO Intl Airport & 8,150 & 8,180 & 8,645 \\
\hline Pleasant Hill & 3,657 & 6,354 & 10,899 & $\begin{array}{c}\text { SF-Transbay } \\
\text { Center }\end{array}$ & 44,596 & 143,250 & 234,672 \\
\hline Powell & 27,635 & 83,580 & 265,726 & $\begin{array}{c}\text { So. San Francisco } \\
\text { BART }\end{array}$ & 774 & 4,774 & 7,308 \\
\hline $\begin{array}{l}\text { Railroad } \\
\text { Avenue }\end{array}$ & 1,317 & 2,014 & 3,978 & $\begin{array}{c}\text { So. San Francisco } \\
\text { CT }\end{array}$ & 1,560 & 6,299 & 18,387 \\
\hline Redwood City & 6,386 & 10,830 & 22,738 & $\begin{array}{c}\text { Sommersville } \\
\text { Road }\end{array}$ & 778 & 3,762 & 5,757 \\
\hline Richmond & 353 & 2,759 & 7,544 & South Calaveras & 2,085 & 5,318 & 10,740 \\
\hline Rockridge & 1,686 & 3,193 & 12,316 & South Hayward & 337 & 750 & 1,793 \\
\hline San Antonio & 587 & 2,910 & 11,051 & Sunnyvale & 1,402 & 8,652 & 22,242 \\
\hline $\begin{array}{l}\text { San Bruno } \\
\text { BART }\end{array}$ & 1,297 & 6,533 & 21,005 & Tamien & 364 & 1,162 & 9,356 \\
\hline San Bruno CT & 492 & 2,143 & 14,096 & Union City & 1,393 & 1,812 & 4,428 \\
\hline San Carlos & 1,272 & 5,248 & 13,780 & Walnut Creek & 7,118 & 17,377 & 27,684 \\
\hline San Leandro & 2,680 & 6,227 & 10,549 & Warm Springs & 134 & 562 & 11,666 \\
\hline San Martin & 71 & 193 & 610 & West Dublin & 225 & 10,166 & 19,563 \\
\hline San Mateo & 3,998 & 7,732 & 11,386 & West Oakland & 683 & 3,443 & 9,121 \\
\hline Santa Clara & 1,088 & 5,858 & 16,137 & Willow Rd & 2,101 & 4,185 & 5,865 \\
\hline $\begin{array}{c}\text { SF-22nd } \\
\text { Street }\end{array}$ & 500 & 4,615 & 19,526 & & & & \\
\hline
\end{tabular}

Source: US Census - Local Employment Dynamics (2009) 
Table X3.2

Calibrated Friction Factors from MTC BAYCAST-90 Travel Model

\begin{tabular}{|c|c|c|c|c|c|c|c|}
\hline Time & $\begin{array}{r}\text { Friction } \\
\text { Factor }\end{array}$ & Time & $\begin{array}{r}\text { Friction } \\
\text { Factor }\end{array}$ & Time & $\begin{array}{r}\text { Friction } \\
\text { Factor }\end{array}$ & Time & $\begin{array}{r}\text { Friction } \\
\text { Factor }\end{array}$ \\
\hline 1 & 355,000 & 34 & 575 & 67 & 38.75 & 100 & 2.75 \\
\hline 2 & 253,750 & 35 & 518.75 & 68 & 35.25 & 101 & 2.6 \\
\hline 3 & 145,750 & 36 & 471.25 & 69 & 32.5 & 102 & 2.45 \\
\hline 4 & 57,750 & 37 & 427.5 & 70 & 29.5 & 103 & 2.3 \\
\hline 5 & 33,000 & 38 & 393.75 & 71 & 26.75 & 104 & 2.15 \\
\hline 6 & 27,450 & 39 & 362.5 & 72 & 24.25 & 105 & 2 \\
\hline 7 & 20,225 & 40 & 337.5 & 73 & 21.75 & 106 & 1.95 \\
\hline 8 & 16,500 & 41 & 303.75 & 74 & 19.5 & 107 & 1.9 \\
\hline 9 & 14,025 & 42 & 275 & 75 & 17.75 & 108 & 1.85 \\
\hline 10 & 11,975 & 43 & 251.25 & 76 & 16.75 & 109 & 1.8 \\
\hline 11 & 10,450 & 44 & 228.75 & 77 & 15.5 & 110 & 1.75 \\
\hline 12 & 8,350 & 45 & 207.5 & 78 & 14.5 & 111 & 1.6 \\
\hline 13 & 6,700 & 46 & 187.5 & 79 & 13 & 112 & 1.45 \\
\hline 14 & 5,750 & 47 & 172.5 & 80 & 11.75 & 113 & 1.3 \\
\hline 15 & 5,000 & 48 & 162.5 & 81 & 10.5 & 114 & 1.15 \\
\hline 16 & 4,575 & 49 & 148.75 & 82 & 9.75 & 115 & 1 \\
\hline 17 & 3,925 & 50 & 137.5 & 83 & 8.75 & 116 & 1 \\
\hline 18 & 3,575 & 51 & 127.5 & 84 & 8.25 & 117 & 1 \\
\hline 19 & 3,200 & 52 & 117.5 & 85 & 8 & 118 & 1 \\
\hline 20 & 2,825 & 53 & 109 & 86 & 7.5 & 119 & 1 \\
\hline 21 & 2,575 & 54 & 100.5 & 87 & 7 & 120 & 1 \\
\hline 22 & 2287.5 & 55 & 93.25 & 88 & 7 & 121 & 1 \\
\hline 23 & 2,000 & 56 & 87.25 & 89 & 6.75 & 122 & 1 \\
\hline 24 & 1,825 & 57 & 81.75 & 90 & 6 & 123 & 1 \\
\hline 25 & 1612.5 & 58 & 77.5 & 91 & 6 & 124 & 1 \\
\hline 26 & 1,425 & 59 & 73.75 & 92 & 5.75 & 125 & 1 \\
\hline 27 & 1,225 & 60 & 69.5 & 93 & 5.25 & 126 & 1 \\
\hline 28 & 1,100 & 61 & 64.75 & 94 & 4.75 & 127 & 1 \\
\hline 29 & 1,000 & 62 & 60 & 95 & 4.5 & 128 & 1 \\
\hline 30 & 875 & 63 & 55.5 & 96 & 3.75 & 129 & 1 \\
\hline 31 & 787.5 & 64 & 51.25 & 97 & 3.75 & 130 & 1 \\
\hline 32 & 718.75 & 65 & 47 & 98 & 3.25 & 131 & 1 \\
\hline 33 & 643.75 & 66 & 42.75 & 99 & 3 & 132 & 1 \\
\hline
\end{tabular}

Source: SF-MTC BAYCAST-90 Travel Demand Study, Table 3 (1997) 
Table X3.3

Generic Friction Factors $\left(\mathrm{F}_{\mathrm{f}}=\mathrm{T}^{-1}\right)$

\begin{tabular}{|c|c|c|c|c|c|c|c|}
\hline Time & $\begin{array}{r}\text { Friction } \\
\text { Factor }\end{array}$ & Time & $\begin{array}{r}\text { Friction } \\
\text { Factor }\end{array}$ & Time & $\begin{array}{r}\text { Friction } \\
\text { Factor }\end{array}$ & Time & $\begin{array}{r}\text { Friction } \\
\text { Factor }\end{array}$ \\
\hline 1 & 1.000 & 34 & 0.029 & 67 & 0.015 & 100 & 0.010 \\
\hline 2 & 0.500 & 35 & 0.029 & 68 & 0.015 & 101 & 0.010 \\
\hline 3 & 0.333 & 36 & 0.028 & 69 & 0.014 & 102 & 0.010 \\
\hline 4 & 0.250 & 37 & 0.027 & 70 & 0.014 & 103 & 0.010 \\
\hline 5 & 0.200 & 38 & 0.026 & 71 & 0.014 & 104 & 0.010 \\
\hline 6 & 0.167 & 39 & 0.026 & 72 & 0.014 & 105 & 0.010 \\
\hline 7 & 0.143 & 40 & 0.025 & 73 & 0.014 & 106 & 0.009 \\
\hline 8 & 0.125 & 41 & 0.024 & 74 & 0.014 & 107 & 0.009 \\
\hline 9 & 0.111 & 42 & 0.024 & 75 & 0.013 & 108 & 0.009 \\
\hline 10 & 0.100 & 43 & 0.023 & 76 & 0.013 & 109 & 0.009 \\
\hline 11 & 0.091 & 44 & 0.023 & 77 & 0.013 & 110 & 0.009 \\
\hline 12 & 0.083 & 45 & 0.022 & 78 & 0.013 & 111 & 0.009 \\
\hline 13 & 0.077 & 46 & 0.022 & 79 & 0.013 & 112 & 0.009 \\
\hline 14 & 0.071 & 47 & 0.021 & 80 & 0.013 & 113 & 0.009 \\
\hline 15 & 0.067 & 48 & 0.021 & 81 & 0.012 & 114 & 0.009 \\
\hline 16 & 0.063 & 49 & 0.020 & 82 & 0.012 & 115 & 0.009 \\
\hline 17 & 0.059 & 50 & 0.020 & 83 & 0.012 & 116 & 0.009 \\
\hline 18 & 0.056 & 51 & 0.020 & 84 & 0.012 & 117 & 0.009 \\
\hline 19 & 0.053 & 52 & 0.019 & 85 & 0.012 & 118 & 0.008 \\
\hline 20 & 0.050 & 53 & 0.019 & 86 & 0.012 & 119 & 0.008 \\
\hline 21 & 0.048 & 54 & 0.019 & 87 & 0.011 & 120 & 0.008 \\
\hline 22 & 0.045 & 55 & 0.018 & 88 & 0.011 & 121 & 0.008 \\
\hline 23 & 0.043 & 56 & 0.018 & 89 & 0.011 & 122 & 0.008 \\
\hline 24 & 0.042 & 57 & 0.018 & 90 & 0.011 & 123 & 0.008 \\
\hline 25 & 0.040 & 58 & 0.017 & 91 & 0.011 & 124 & 0.008 \\
\hline 26 & 0.038 & 59 & 0.017 & 92 & 0.011 & 125 & 0.008 \\
\hline 27 & 0.037 & 60 & 0.017 & 93 & 0.011 & 126 & 0.008 \\
\hline 28 & 0.036 & 61 & 0.016 & 94 & 0.011 & 127 & 0.008 \\
\hline 29 & 0.034 & 62 & 0.016 & 95 & 0.011 & 128 & 0.008 \\
\hline 30 & 0.033 & 63 & 0.016 & 96 & 0.010 & 129 & 0.008 \\
\hline 31 & 0.032 & 64 & 0.016 & 97 & 0.010 & 130 & 0.008 \\
\hline 32 & 0.031 & 65 & 0.015 & 98 & 0.010 & 131 & 0.008 \\
\hline 33 & 0.030 & 66 & 0.015 & 99 & 0.010 & 132 & 0.008 \\
\hline
\end{tabular}




\section{Appendices to Chapter 4}

Table X4.1

Accessibility Indices - Alternative Network Configuration A

\begin{tabular}{|c|c|c|c|c|}
\hline \multirow[b]{2}{*}{ Station } & \multirow{2}{*}{$\begin{array}{r}\text { Average } \\
\text { Accessibility } \\
\text { Index }\end{array}$} & \multicolumn{3}{|c|}{ Radius Distance } \\
\hline & & $\begin{array}{r}\text { Quarter } \\
\text { Mile }\end{array}$ & Half Mile & One Mile \\
\hline 12th Street-Oakland & 24.56 & 7.29 & 21.05 & 45.33 \\
\hline 16th Street-Mission & 33.93 & 6.88 & 21.68 & 73.22 \\
\hline 19th Street-Oakland & 22.32 & 8.39 & 20.65 & 37.93 \\
\hline 24th Street-Mission & 23.99 & 3.72 & 19.85 & 48.41 \\
\hline 4th and King & 0.47 & 0.08 & 0.31 & 1.00 \\
\hline Ashby & 7.87 & 2.53 & 7.60 & 13.47 \\
\hline Atherton & 3.03 & 1.27 & 2.67 & 5.14 \\
\hline Balboa Park & 6.27 & 1.29 & 4.74 & 12.78 \\
\hline Bayfair & 2.19 & 0.54 & 1.72 & 4.32 \\
\hline Bayshore & 1.26 & 0.18 & 0.76 & 2.85 \\
\hline Belmont & 2.68 & 0.58 & 2.09 & 5.38 \\
\hline Berkeley & 4.93 & 0.80 & 2.57 & 11.40 \\
\hline Blossom Hill & 0.22 & 0.03 & 0.13 & 0.51 \\
\hline Broadway & 2.36 & 0.71 & 1.65 & 4.72 \\
\hline Burlingame & 3.20 & 0.92 & 2.76 & 5.92 \\
\hline California Avenue & 2.08 & 0.48 & 1.58 & 4.18 \\
\hline Capitol & 0.46 & 0.06 & 0.29 & 1.04 \\
\hline Castro Valley & 1.28 & 0.33 & 1.00 & 2.51 \\
\hline Civic Center & 56.60 & 12.25 & 43.94 & 113.60 \\
\hline Coliseum/OAK Airport & 4.03 & 1.14 & 3.38 & 7.57 \\
\hline College Park & 3.68 & 0.53 & 2.02 & 8.50 \\
\hline Colma & 3.09 & 0.69 & 2.50 & 6.07 \\
\hline Concord & 0.96 & 0.33 & 0.74 & 1.80 \\
\hline Daly City & 3.77 & 0.91 & 2.92 & 7.49 \\
\hline Diridon & 1.75 & 0.21 & 1.12 & 3.94 \\
\hline East Dublin/Pleasanton & 1.72 & 0.10 & 1.68 & 3.36 \\
\hline El Cerrito del Norte & 1.92 & 0.55 & 1.57 & 3.65 \\
\hline El Cerrito Plaza & 2.49 & 0.66 & 2.03 & 4.80 \\
\hline Embarcadero & 78.48 & 27.63 & 72.00 & 135.82 \\
\hline Fremont & 0.34 & 0.11 & 0.26 & 0.65 \\
\hline Fruitvale & 5.57 & 1.38 & 4.79 & 10.52 \\
\hline Gilroy & 0.03 & 0.01 & 0.03 & 0.07 \\
\hline Glenn Park & 10.06 & 2.60 & 7.65 & 19.93 \\
\hline
\end{tabular}




\begin{tabular}{|c|c|c|c|c|}
\hline \multirow[b]{2}{*}{ Station } & \multirow{2}{*}{$\begin{array}{r}\text { Average } \\
\text { Accessibility } \\
\text { Index }\end{array}$} & \multicolumn{3}{|c|}{ Radius Distance } \\
\hline & & $\begin{array}{r}\text { Quarter } \\
\text { Mile }\end{array}$ & Half Mile & One Mile \\
\hline Hayward & 1.25 & 0.36 & 0.98 & 2.41 \\
\hline Hayward Park & 2.82 & 0.93 & 2.40 & 5.14 \\
\hline Hillsdale & 3.63 & 0.76 & 2.43 & 7.71 \\
\hline Lafayette & 2.22 & 0.78 & 2.01 & 3.87 \\
\hline Lake Merritt & 13.13 & 4.77 & 11.95 & 22.66 \\
\hline Lawrence & 1.41 & 0.22 & 1.04 & 2.98 \\
\hline MacArthur & 12.37 & 4.24 & 11.05 & 21.81 \\
\hline Menlo Park & 4.18 & 0.90 & 3.17 & 8.46 \\
\hline Millbrae & 2.74 & 0.64 & 2.00 & 5.58 \\
\hline Montgomery & 64.95 & 10.52 & 36.97 & 147.36 \\
\hline Morgan Hill & 0.10 & 0.01 & 0.07 & 0.22 \\
\hline Mountain View & 1.71 & 0.33 & 1.24 & 3.55 \\
\hline North Berkeley & 8.93 & 3.18 & 9.76 & 13.85 \\
\hline North Concord & 0.96 & 0.17 & 0.87 & 1.84 \\
\hline Orinda & 2.27 & 0.68 & 1.88 & 4.25 \\
\hline Palo Alto & 2.48 & 1.02 & 2.26 & 4.16 \\
\hline Pittsburg & 0.39 & 0.08 & 0.29 & 0.79 \\
\hline Pleasant Hill & 3.38 & 1.19 & 3.23 & 5.72 \\
\hline Powell & 72.13 & 20.40 & 58.17 & 137.83 \\
\hline Redwood City & 1.67 & 0.41 & 1.28 & 3.31 \\
\hline Richmond & 0.88 & 0.26 & 0.73 & 1.66 \\
\hline Rockridge & 4.06 & 1.16 & 3.27 & 7.75 \\
\hline San Antonio & 1.66 & 0.45 & 1.37 & 3.15 \\
\hline San Bruno BART & 2.50 & 0.68 & 1.77 & 5.04 \\
\hline San Bruno CT & 2.16 & 0.40 & 1.41 & 4.66 \\
\hline San Carlos & 2.45 & 0.76 & 1.74 & 4.83 \\
\hline San Leandro & 2.45 & 0.59 & 1.99 & 4.78 \\
\hline San Martin & 0.15 & 0.03 & 0.12 & 0.29 \\
\hline San Mateo & 3.52 & 0.81 & 2.42 & 7.33 \\
\hline Santa Clara & 1.48 & 0.25 & 0.94 & 3.25 \\
\hline SF-22nd Street & 1.20 & 0.14 & 0.67 & 2.78 \\
\hline SFO Intl Airport & 1.29 & 0.24 & 0.91 & 2.73 \\
\hline So. San Francisco BART & 3.04 & 0.66 & 2.28 & 6.18 \\
\hline So. San Francisco CT & 1.32 & 0.22 & 0.80 & 2.95 \\
\hline South Hayward & 1.12 & 0.29 & 0.82 & 2.25 \\
\hline Sunnyvale & 1.59 & 0.38 & 1.12 & 3.28 \\
\hline Tamien & 0.96 & 0.14 & 0.56 & 2.18 \\
\hline Union City & 0.79 & 0.23 & 0.63 & 1.50 \\
\hline
\end{tabular}




\begin{tabular}{|l|r|r|r|r|}
\hline \multirow{2}{*}{ Station } & Average & \multicolumn{3}{|c|}{ Radius Distance } \\
\cline { 3 - 5 } & $\begin{array}{r}\text { Accessibility } \\
\text { Index }\end{array}$ & $\begin{array}{r}\text { Quarter } \\
\text { Mile }\end{array}$ & Half Mile & One Mile \\
\hline Walnut Creek & 2.00 & 0.77 & 1.75 & 3.47 \\
\hline West Dublin/Pleasanton & 1.77 & 0.10 & 0.75 & 4.46 \\
\hline West Oakland & 11.42 & 3.36 & 9.61 & 21.30 \\
\hline
\end{tabular}

*Average accessibility indices are portrayed in the summary tables and maps in Chapter 4 
Table X4.2

Accessibility Indices - Alternative Network Configuration B

\begin{tabular}{|c|c|c|c|c|}
\hline \multirow[b]{2}{*}{ Station } & \multirow{2}{*}{$\begin{array}{r}\text { Average } \\
\text { Accessibility } \\
\text { Index }\end{array}$} & \multicolumn{3}{|c|}{ Radius Distance } \\
\hline & & $\begin{array}{r}\text { Quarter } \\
\text { Mile }\end{array}$ & Half Mile & One Mile \\
\hline 12th Street-Oakland & 24.57 & 7.29 & 21.06 & 45.36 \\
\hline 16th Street-Mission & 33.95 & 6.89 & 21.71 & 73.26 \\
\hline 19th Street-Oakland & 22.33 & 8.39 & 20.66 & 37.95 \\
\hline 24th Street-Mission & 24.02 & 3.72 & 19.87 & 48.45 \\
\hline 4th and King & 8.62 & 2.68 & 8.61 & 14.58 \\
\hline Alum Rock & 7.19 & 1.97 & 7.04 & 12.55 \\
\hline Antioch Fairgrounds & 1.44 & 0.35 & 1.51 & 2.47 \\
\hline Ashby & 7.88 & 2.53 & 7.61 & 13.49 \\
\hline Atherton & 3.06 & 1.28 & 2.70 & 5.19 \\
\hline Balboa Park & 6.31 & 1.30 & 4.78 & 12.85 \\
\hline Bayfair & 2.24 & 0.55 & 1.75 & 4.41 \\
\hline Bayshore & 1.94 & 0.41 & 1.45 & 3.96 \\
\hline Belmont & 2.72 & 0.60 & 2.12 & 5.43 \\
\hline Berkeley & 4.93 & 0.81 & 2.58 & 11.41 \\
\hline Berryessa & 3.15 & 0.89 & 2.74 & 5.82 \\
\hline Blossom Hill & 0.41 & 0.11 & 0.32 & 0.80 \\
\hline Brentwood & 0.12 & 0.02 & 0.08 & 0.26 \\
\hline Broadway & 2.49 & 0.78 & 1.78 & 4.90 \\
\hline Burlingame & 3.28 & 0.96 & 2.84 & 6.04 \\
\hline Byron & 0.08 & 0.03 & 0.06 & 0.16 \\
\hline California Avenue & 2.14 & 0.51 & 1.64 & 4.27 \\
\hline Capitol & 0.83 & 0.23 & 0.66 & 1.60 \\
\hline Castro Valley & 1.31 & 0.33 & 1.02 & 2.57 \\
\hline Civic Center & 56.62 & 12.26 & 43.96 & 113.64 \\
\hline Civic Center/SJSU & 19.04 & 10.10 & 16.05 & 30.97 \\
\hline Coliseum/OAK Airport & 4.05 & 1.14 & 3.40 & 7.62 \\
\hline College Park & 6.65 & 2.11 & 5.07 & 12.78 \\
\hline Colma & 3.18 & 0.72 & 2.59 & 6.21 \\
\hline Concord & 0.99 & 0.34 & 0.77 & 1.85 \\
\hline Daly City & 3.83 & 0.92 & 2.98 & 7.59 \\
\hline Diridon & 20.30 & 9.80 & 20.62 & 30.48 \\
\hline East Dublin/Pleasanton & 1.73 & 0.10 & 1.69 & 3.38 \\
\hline El Cerrito del Norte & 1.92 & 0.55 & 1.57 & 3.65 \\
\hline El Cerrito Plaza & 2.50 & 0.66 & 2.03 & 4.80 \\
\hline Embarcadero & 78.50 & 27.63 & 72.01 & 135.85 \\
\hline Fremont & 0.75 & 0.20 & 0.54 & 1.51 \\
\hline
\end{tabular}




\begin{tabular}{|c|c|c|c|c|}
\hline \multirow[b]{2}{*}{ Station } & \multirow{2}{*}{$\begin{array}{r}\text { Average } \\
\text { Accessibility } \\
\text { Index }\end{array}$} & \multicolumn{3}{|c|}{ Radius Distance } \\
\hline & & $\begin{array}{r}\text { Quarter } \\
\text { Mile }\end{array}$ & Half Mile & One Mile \\
\hline Fruitvale & 5.58 & 1.39 & 4.81 & 10.56 \\
\hline Gilroy & 0.04 & 0.01 & 0.04 & 0.09 \\
\hline Glenn Park & 10.10 & 2.62 & 7.69 & 19.99 \\
\hline Hayward & 1.32 & 0.38 & 1.03 & 2.54 \\
\hline Hayward Park & 2.87 & 0.95 & 2.44 & 5.21 \\
\hline Hillcrest Avenue & 0.31 & 0.07 & 0.25 & 0.62 \\
\hline Hillsdale & 3.80 & 0.83 & 2.60 & 7.97 \\
\hline Irvington & 1.73 & 0.38 & 1.04 & 3.78 \\
\hline Lafayette & 2.23 & 0.79 & 2.02 & 3.89 \\
\hline Lake Merritt & 13.14 & 4.77 & 11.96 & 22.69 \\
\hline Lawrence & 1.84 & 0.41 & 1.47 & 3.63 \\
\hline MacArthur & 12.38 & 4.24 & 11.05 & 21.83 \\
\hline Market Street-San Jose & 16.23 & 1.65 & 13.73 & 33.32 \\
\hline Menlo Park & 4.29 & 0.95 & 3.29 & 8.64 \\
\hline Millbrae & 3.26 & 0.91 & 2.52 & 6.35 \\
\hline Montague & 2.26 & 0.71 & 1.89 & 4.17 \\
\hline Montgomery & 64.97 & 10.52 & 36.98 & 147.39 \\
\hline Morgan Hill & 0.14 & 0.03 & 0.11 & 0.29 \\
\hline Mountain View & 2.15 & 0.53 & 1.69 & 4.23 \\
\hline North Berkeley & 8.94 & 3.18 & 9.77 & 13.86 \\
\hline North Concord & 1.01 & 0.19 & 0.92 & 1.93 \\
\hline Oakley & 0.30 & 0.11 & 0.23 & 0.56 \\
\hline Orinda & 2.28 & 0.69 & 1.89 & 4.27 \\
\hline Palo Alto & 2.68 & 1.10 & 2.47 & 4.48 \\
\hline Pittsburg & 0.54 & 0.14 & 0.42 & 1.07 \\
\hline Pleasant Hill & 3.40 & 1.19 & 3.25 & 5.75 \\
\hline Powell & 72.15 & 20.40 & 58.19 & 137.86 \\
\hline Railroad Avenue & 0.40 & 0.08 & 0.33 & 0.78 \\
\hline Redwood City & 1.77 & 0.45 & 1.39 & 3.47 \\
\hline Richmond & 0.89 & 0.26 & 0.74 & 1.66 \\
\hline Rockridge & 4.07 & 1.16 & 3.28 & 7.77 \\
\hline San Antonio & 1.75 & 0.50 & 1.47 & 3.29 \\
\hline San Bruno BART & 2.72 & 0.75 & 1.99 & 5.41 \\
\hline San Bruno CT & 2.59 & 0.69 & 1.85 & 5.25 \\
\hline San Carlos & 2.47 & 0.77 & 1.77 & 4.86 \\
\hline San Leandro & 2.48 & 0.60 & 2.01 & 4.85 \\
\hline San Martin & 0.17 & 0.04 & 0.14 & 0.33 \\
\hline San Mateo & 3.76 & 0.92 & 2.66 & 7.69 \\
\hline
\end{tabular}




\begin{tabular}{|l|r|r|r|r|}
\hline \multirow{2}{*}{ Station } & $\begin{array}{r}\text { Average } \\
\text { Accessibility } \\
\text { Index }\end{array}$ & $\begin{array}{c}\text { Quarter } \\
\text { Mile }\end{array}$ & Half Mile & One Mile \\
\cline { 4 - 5 } & 2.48 & 0.71 & 1.97 & 4.76 \\
\hline Santa Clara & 2.61 & 0.25 & 1.28 & 6.31 \\
\hline SF-Transbay Center & 2.69 & 0.62 & 2.18 & 5.26 \\
\hline SF-22nd Street & 2.30 & 0.44 & 1.62 & 4.83 \\
\hline SFO Intl Airport & 3.16 & 0.70 & 2.40 & 6.38 \\
\hline So. San Francisco BART & 1.74 & 0.41 & 1.22 & 3.59 \\
\hline So. San Francisco CT & 0.96 & 0.11 & 0.58 & 2.18 \\
\hline Sommersville Road & 2.44 & 0.49 & 2.02 & 4.80 \\
\hline South Calaveras & 1.22 & 0.32 & 0.89 & 2.46 \\
\hline South Hayward & 2.24 & 0.68 & 1.78 & 4.25 \\
\hline Sunnyvale & 2.17 & 0.71 & 1.81 & 3.99 \\
\hline Tamien & 0.97 & 0.27 & 0.76 & 1.88 \\
\hline Union City & 2.01 & 0.77 & 1.76 & 3.50 \\
\hline Walnut Creek & 1.21 & 0.33 & 1.00 & 2.28 \\
\hline Warm Springs & 1.78 & 0.11 & 0.76 & 4.49 \\
\hline West Dublin/Pleasanton & 11.44 & 3.36 & 9.62 & 21.33 \\
\hline West Oakland & & & \\
\hline
\end{tabular}

*Average accessibility indices are portrayed in the summary tables and maps in Chapter 4 
Table X4.3

Accessibility Indices - Alternative Network Configuration C

\begin{tabular}{|c|c|c|c|c|}
\hline \multirow[b]{2}{*}{ Station } & \multirow{2}{*}{$\begin{array}{r}\text { Average } \\
\text { Accessibility } \\
\text { Index }\end{array}$} & \multicolumn{3}{|c|}{ Radius Distance } \\
\hline & & $\begin{array}{r}\text { Quarter } \\
\text { Mile }\end{array}$ & Half Mile & One Mile \\
\hline 12th Street-Oakland & 24.57 & 7.30 & 21.06 & 45.36 \\
\hline 16th Street-Mission & 33.95 & 6.89 & 21.71 & 73.26 \\
\hline 19th Street-Oakland & 22.34 & 8.39 & 20.66 & 37.96 \\
\hline 24th Street-Mission & 24.02 & 3.73 & 19.88 & 48.46 \\
\hline 4th and King & 8.63 & 2.68 & 8.61 & 14.59 \\
\hline Alum Rock & 7.20 & 1.98 & 7.05 & 12.57 \\
\hline Antioch Fairgrounds & 1.44 & 0.35 & 1.51 & 2.47 \\
\hline Ashby & 7.88 & 2.53 & 7.61 & 13.49 \\
\hline Atherton & 3.12 & 1.32 & 2.76 & 5.30 \\
\hline Balboa Park & 6.32 & 1.31 & 4.79 & 12.86 \\
\hline Bayfair & 2.27 & 0.57 & 1.78 & 4.47 \\
\hline Bayshore & 1.94 & 0.41 & 1.45 & 3.96 \\
\hline Belmont & 2.77 & 0.62 & 2.17 & 5.51 \\
\hline Berkeley & 4.93 & 0.81 & 2.58 & 11.41 \\
\hline Berryessa & 3.15 & 0.89 & 2.74 & 5.83 \\
\hline Blossom Hill & 0.41 & 0.11 & 0.32 & 0.80 \\
\hline Brentwood & 0.12 & 0.02 & 0.08 & 0.26 \\
\hline Broadway & 2.50 & 0.79 & 1.79 & 4.91 \\
\hline Burlingame & 3.29 & 0.97 & 2.85 & 6.06 \\
\hline Byron & 0.08 & 0.03 & 0.06 & 0.16 \\
\hline California Avenue & 2.16 & 0.52 & 1.66 & 4.31 \\
\hline Capitol & 0.83 & 0.23 & 0.67 & 1.61 \\
\hline Castro Valley & 1.33 & 0.34 & 1.04 & 2.62 \\
\hline Centerville & 0.82 & 0.30 & 0.66 & 1.49 \\
\hline Civic Center & 56.62 & 12.26 & 43.96 & 113.64 \\
\hline Civic Center/SJSU & 19.05 & 10.11 & 16.06 & 30.99 \\
\hline Coliseum/OAK Airport & 4.07 & 1.15 & 3.41 & 7.64 \\
\hline College Park & 6.65 & 2.11 & 5.07 & 12.79 \\
\hline Colma & 3.19 & 0.72 & 2.60 & 6.23 \\
\hline Concord & 0.99 & 0.34 & 0.77 & 1.86 \\
\hline Daly City & 3.84 & 0.93 & 2.99 & 7.60 \\
\hline Diridon & 20.32 & 9.81 & 20.63 & 30.51 \\
\hline East Dublin/Pleasanton & 1.73 & 0.11 & 1.70 & 3.40 \\
\hline El Cerrito del Norte & 1.92 & 0.55 & 1.57 & 3.65 \\
\hline El Cerrito Plaza & 2.50 & 0.66 & 2.03 & 4.81 \\
\hline Embarcadero & 78.50 & 27.64 & 72.01 & 135.85 \\
\hline
\end{tabular}




\begin{tabular}{|c|c|c|c|c|}
\hline \multirow[b]{2}{*}{ Station } & \multirow{2}{*}{$\begin{array}{r}\text { Average } \\
\text { Accessibility } \\
\text { Index }\end{array}$} & \multicolumn{3}{|c|}{ Radius Distance } \\
\hline & & $\begin{array}{r}\text { Quarter } \\
\text { Mile }\end{array}$ & Half Mile & One Mile \\
\hline Fremont & 0.84 & 0.23 & 0.62 & 1.67 \\
\hline Fruitvale & 5.59 & 1.39 & 4.82 & 10.58 \\
\hline Gilroy & 0.04 & 0.01 & 0.04 & 0.09 \\
\hline Glenn Park & 10.10 & 2.62 & 7.69 & 20.00 \\
\hline Hayward & 1.37 & 0.40 & 1.08 & 2.64 \\
\hline Hayward Park & 2.90 & 0.97 & 2.47 & 5.25 \\
\hline Hillcrest Avenue & 0.31 & 0.07 & 0.25 & 0.62 \\
\hline Hillsdale & 3.84 & 0.85 & 2.64 & 8.03 \\
\hline Irvington & 1.78 & 0.40 & 1.07 & 3.86 \\
\hline Lafayette & 2.23 & 0.79 & 2.02 & 3.89 \\
\hline Lake Merritt & 13.15 & 4.78 & 11.97 & 22.70 \\
\hline Lawrence & 1.84 & 0.41 & 1.48 & 3.63 \\
\hline MacArthur & 12.38 & 4.24 & 11.06 & 21.84 \\
\hline Market Street-San Jose & 16.24 & 1.65 & 13.74 & 33.35 \\
\hline Menlo Park & 4.34 & 0.97 & 3.33 & 8.71 \\
\hline Millbrae & 3.29 & 0.92 & 2.55 & 6.39 \\
\hline Montague & 2.27 & 0.71 & 1.90 & 4.19 \\
\hline Montgomery & 64.97 & 10.52 & 36.98 & 147.39 \\
\hline Morgan Hill & 0.14 & 0.03 & 0.11 & 0.29 \\
\hline Mountain View & 2.16 & 0.53 & 1.70 & 4.24 \\
\hline Newark & 0.73 & 0.25 & 0.59 & 1.34 \\
\hline North Berkeley & 8.94 & 3.18 & 9.77 & 13.86 \\
\hline North Concord & 1.01 & 0.19 & 0.92 & 1.93 \\
\hline Oakley & 0.30 & 0.11 & 0.23 & 0.56 \\
\hline Orinda & 2.28 & 0.69 & 1.89 & 4.27 \\
\hline Palo Alto & 2.71 & 1.12 & 2.49 & 4.52 \\
\hline Pittsburg & 0.54 & 0.14 & 0.42 & 1.07 \\
\hline Pleasant Hill & 3.40 & 1.19 & 3.25 & 5.75 \\
\hline Powell & 72.15 & 20.40 & 58.19 & 137.86 \\
\hline Railroad Avenue & 0.40 & 0.08 & 0.33 & 0.79 \\
\hline Redwood City & 1.88 & 0.50 & 1.49 & 3.65 \\
\hline Richmond & 0.89 & 0.26 & 0.74 & 1.66 \\
\hline Rockridge & 4.07 & 1.16 & 3.28 & 7.77 \\
\hline San Antonio & 1.76 & 0.50 & 1.48 & 3.31 \\
\hline San Bruno BART & 2.74 & 0.76 & 2.01 & 5.45 \\
\hline San Bruno CT & 2.60 & 0.69 & 1.86 & 5.26 \\
\hline San Carlos & 2.55 & 0.81 & 1.84 & 5.00 \\
\hline San Leandro & 2.51 & 0.61 & 2.03 & 4.88 \\
\hline
\end{tabular}




\begin{tabular}{|l|r|r|r|c|}
\hline \multirow{2}{*}{ Station } & $\begin{array}{r}\text { Average } \\
\text { Accessibility } \\
\text { Index }\end{array}$ & $\begin{array}{r}|c| \\
\text { Quarter } \\
\text { Mile }\end{array}$ & Half Mile & One Mile \\
\hline San Martin & 0.17 & 0.04 & 0.14 & 0.33 \\
\hline San Mateo & 3.79 & 0.93 & 2.69 & 7.74 \\
\hline Santa Clara & 2.48 & 0.71 & 1.97 & 4.76 \\
\hline SF-Transbay Center & 2.62 & 0.25 & 1.28 & 6.31 \\
\hline SF-22nd Street & 2.69 & 0.62 & 2.19 & 5.26 \\
\hline SFO Intl Airport & 2.32 & 0.45 & 1.63 & 4.87 \\
\hline So. San Francisco BART & 3.17 & 0.70 & 2.41 & 6.40 \\
\hline So. San Francisco CT & 1.75 & 0.41 & 1.23 & 3.61 \\
\hline Sommersville Road & 0.96 & 0.11 & 0.58 & 2.18 \\
\hline South Calaveras & 2.45 & 0.49 & 2.03 & 4.82 \\
\hline South Hayward & 1.32 & 0.36 & 0.97 & 2.62 \\
\hline Sunnyvale & 2.24 & 0.68 & 1.78 & 4.25 \\
\hline Tamien & 2.17 & 0.71 & 1.81 & 3.99 \\
\hline Union City & 1.16 & 0.35 & 0.91 & 2.21 \\
\hline Walnut Creek & 2.01 & 0.77 & 1.76 & 3.50 \\
\hline Warm Springs & 1.24 & 0.34 & 1.03 & 2.33 \\
\hline West Dublin/Pleasanton & 1.79 & 0.11 & 0.77 & 4.51 \\
\hline West Oakland & 11.44 & 3.36 & 9.62 & 21.33 \\
\hline Willow Road & 0.84 & 0.30 & 0.67 & 1.55 \\
\hline
\end{tabular}

*Average accessibility indices are portrayed in the summary tables and maps in Chapter 4 
Table X4.4

Accessibility Indices and Ranks - Alternative Network Configuration A

\begin{tabular}{|c|c|c|c|c|c|c|c|c|}
\hline \multirow[b]{2}{*}{ Station } & \multicolumn{4}{|c|}{ Accessibility Index } & \multicolumn{4}{|c|}{ Accessibility Rank } \\
\hline & $\begin{array}{r}1 / 4 \\
\text { Mile }\end{array}$ & $\begin{array}{c}1 / 2 \\
\text { Mile }\end{array}$ & 1 Mile & Avg. & $\begin{array}{r}1 / 4 \\
\text { Mile }\end{array}$ & $\begin{array}{r}1 / 2 \\
\text { Mile }\end{array}$ & $\begin{array}{r}1 \\
\text { Mile }\end{array}$ & Avg. \\
\hline 12th Street-Oakland & 7.29 & 21.05 & 45.33 & 24.56 & 6 & 6 & 7 & 6 \\
\hline 16th Street-Mission & 6.88 & 21.68 & 73.22 & 33.93 & 7 & 5 & 5 & 5 \\
\hline 19th Street-Oakland & 8.39 & 20.65 & 37.93 & 22.32 & 5 & 7 & 8 & 8 \\
\hline 24th Street-Mission & 3.72 & 19.85 & 48.41 & 23.99 & 10 & 8 & 6 & 7 \\
\hline 4th and King & 0.08 & 0.31 & 1.00 & 0.47 & 68 & 67 & 68 & 67 \\
\hline Ashby & 2.53 & 7.60 & 13.47 & 7.87 & 14 & 14 & 14 & 14 \\
\hline Atherton & 1.27 & 2.67 & 5.14 & 3.03 & 17 & 23 & 31 & 29 \\
\hline Balboa Park & 1.29 & 4.74 & 12.78 & 6.27 & 16 & 16 & 15 & 15 \\
\hline Bayfair & 0.54 & 1.72 & 4.32 & 2.19 & 42 & 41 & 40 & 41 \\
\hline Bayshore & 0.18 & 0.76 & 2.85 & 1.26 & 61 & 60 & 56 & 58 \\
\hline Belmont & 0.58 & 2.09 & 5.38 & 2.68 & 40 & 31 & 30 & 32 \\
\hline Berkeley & 0.80 & 2.57 & 11.40 & 4.93 & 27 & 24 & 16 & 17 \\
\hline Blossom Hill & 0.03 & 0.13 & 0.51 & 0.22 & 71 & 71 & 71 & 71 \\
\hline Broadway & 0.71 & 1.65 & 4.72 & 2.36 & 32 & 43 & 37 & 38 \\
\hline Burlingame & 0.92 & 2.76 & 5.92 & 3.20 & 23 & 22 & 27 & 26 \\
\hline California Avenue & 0.48 & 1.58 & 4.18 & 2.08 & 44 & 44 & 42 & 43 \\
\hline Capitol & 0.06 & 0.29 & 1.04 & 0.46 & 70 & 68 & 67 & 68 \\
\hline Castro Valley & 0.33 & 1.00 & 2.51 & 1.28 & 52 & 53 & 59 & 57 \\
\hline Civic Center & 12.25 & 43.94 & 113.60 & 56.60 & 3 & 3 & 4 & 4 \\
\hline Coliseum/OAK Airport & 1.14 & 3.38 & 7.57 & 4.03 & 20 & 17 & 22 & 20 \\
\hline College Park & 0.53 & 2.02 & 8.50 & 3.68 & 43 & 33 & 18 & 22 \\
\hline Colma & 0.69 & 2.50 & 6.07 & 3.09 & 33 & 25 & 26 & 27 \\
\hline Concord & 0.33 & 0.74 & 1.80 & 0.96 & 50 & 62 & 64 & 64 \\
\hline Daly City & 0.91 & 2.92 & 7.49 & 3.77 & 24 & 21 & 23 & 21 \\
\hline Diridon & 0.21 & 1.12 & 3.94 & 1.75 & 60 & 51 & 44 & 47 \\
\hline East Dublin/Pleasanton & 0.10 & 1.68 & 3.36 & 1.72 & 67 & 42 & 49 & 48 \\
\hline El Cerrito del Norte & 0.55 & 1.57 & 3.65 & 1.92 & 41 & 45 & 46 & 45 \\
\hline El Cerrito Plaza & 0.66 & 2.03 & 4.80 & 2.49 & 37 & 32 & 35 & 34 \\
\hline Embarcadero & 27.63 & 72.00 & 135.82 & 78.48 & 1 & 1 & 3 & 1 \\
\hline Fremont & 0.11 & 0.26 & 0.65 & 0.34 & 65 & 70 & 70 & 70 \\
\hline Fruitvale & 1.38 & 4.79 & 10.52 & 5.57 & 15 & 15 & 17 & 16 \\
\hline Gilroy & 0.01 & 0.03 & 0.07 & 0.03 & 74 & 74 & 74 & 74 \\
\hline Glenn Park & 2.60 & 7.65 & 19.93 & 10.06 & 13 & 13 & 12 & 12 \\
\hline Hayward & 0.36 & 0.98 & 2.41 & 1.25 & 49 & 54 & 60 & 59 \\
\hline Hayward Park & 0.93 & 2.40 & 5.14 & 2.82 & 22 & 28 & 32 & 30 \\
\hline Hillsdale & 0.76 & 2.43 & 7.71 & 3.63 & 30 & 26 & 21 & 23 \\
\hline
\end{tabular}




\begin{tabular}{|c|c|c|c|c|c|c|c|c|}
\hline \multirow[b]{2}{*}{ Station } & \multicolumn{4}{|c|}{ Accessibility Index } & \multicolumn{4}{|c|}{ Accessibility Rank } \\
\hline & $\begin{array}{r}1 / 4 \\
\text { Mile }\end{array}$ & $\begin{array}{r}1 / 2 \\
\text { Mile }\end{array}$ & 1 Mile & Avg. & $\begin{array}{r}1 / 4 \\
\text { Mile }\end{array}$ & $\begin{array}{r}1 / 2 \\
\text { Mile }\end{array}$ & $\begin{array}{r}1 \\
\text { Mile }\end{array}$ & Avg. \\
\hline Lafayette & 0.78 & 2.01 & 3.87 & 2.22 & 28 & 34 & 45 & 40 \\
\hline Lake Merritt & 4.77 & 11.95 & 22.66 & 13.13 & 8 & 9 & 9 & 9 \\
\hline Lawrence & 0.22 & 1.04 & 2.98 & 1.41 & 58 & 52 & 54 & 54 \\
\hline MacArthur & 4.24 & 11.05 & 21.81 & 12.37 & 9 & 10 & 10 & 10 \\
\hline Menlo Park & 0.90 & 3.17 & 8.46 & 4.18 & 25 & 20 & 19 & 18 \\
\hline Millbrae & 0.64 & 2.00 & 5.58 & 2.74 & 38 & 35 & 29 & 31 \\
\hline Montgomery & 10.52 & 36.97 & 147.36 & 64.95 & 4 & 4 & 1 & 3 \\
\hline Morgan Hill & 0.01 & 0.07 & 0.22 & 0.10 & 73 & 73 & 73 & 73 \\
\hline Mountain View & 0.33 & 1.24 & 3.55 & 1.71 & 51 & 49 & 47 & 49 \\
\hline North Berkeley & 3.18 & 9.76 & 13.85 & 8.93 & 12 & 11 & 13 & 13 \\
\hline North Concord & 0.17 & 0.87 & 1.84 & 0.96 & 62 & 57 & 63 & 63 \\
\hline Orinda & 0.68 & 1.88 & 4.25 & 2.27 & 34 & 37 & 41 & 39 \\
\hline Palo Alto & 1.02 & 2.26 & 4.16 & 2.48 & 21 & 30 & 43 & 35 \\
\hline Pittsburg & 0.08 & 0.29 & 0.79 & 0.39 & 69 & 69 & 69 & 69 \\
\hline Pleasant Hill & 1.19 & 3.23 & 5.72 & 3.38 & 18 & 19 & 28 & 25 \\
\hline Powell & 20.40 & 58.17 & 137.83 & 72.13 & 2 & 2 & 2 & 2 \\
\hline Redwood City & 0.41 & 1.28 & 3.31 & 1.67 & 46 & 48 & 50 & 50 \\
\hline Richmond & 0.26 & 0.73 & 1.66 & 0.88 & 54 & 63 & 65 & 65 \\
\hline Rockridge & 1.16 & 3.27 & 7.75 & 4.06 & 19 & 18 & 20 & 19 \\
\hline San Antonio & 0.45 & 1.37 & 3.15 & 1.66 & 45 & 47 & 53 & 51 \\
\hline San Bruno BART & 0.68 & 1.77 & 5.04 & 2.50 & 35 & 38 & 33 & 33 \\
\hline San Bruno CT & 0.40 & 1.41 & 4.66 & 2.16 & 47 & 46 & 38 & 42 \\
\hline San Carlos & 0.76 & 1.74 & 4.83 & 2.45 & 31 & 40 & 34 & 37 \\
\hline San Leandro & 0.59 & 1.99 & 4.78 & 2.45 & 39 & 36 & 36 & 36 \\
\hline San Martin & 0.03 & 0.12 & 0.29 & 0.15 & 72 & 72 & 72 & 72 \\
\hline San Mateo & 0.81 & 2.42 & 7.33 & 3.52 & 26 & 27 & 24 & 24 \\
\hline Santa Clara & 0.25 & 0.94 & 3.25 & 1.48 & 55 & 55 & 52 & 53 \\
\hline SF-22nd Street & 0.14 & 0.67 & 2.78 & 1.20 & 63 & 64 & 57 & 60 \\
\hline SFO Intl Airport & 0.24 & 0.91 & 2.73 & 1.29 & 56 & 56 & 58 & 56 \\
\hline So. San Francisco BART & 0.66 & 2.28 & 6.18 & 3.04 & 36 & 29 & 25 & 28 \\
\hline So. San Francisco CT & 0.22 & 0.80 & 2.95 & 1.32 & 59 & 59 & 55 & 55 \\
\hline South Hayward & 0.29 & 0.82 & 2.25 & 1.12 & 53 & 58 & 61 & 61 \\
\hline Sunnyvale & 0.38 & 1.12 & 3.28 & 1.59 & 48 & 50 & 51 & 52 \\
\hline Tamien & 0.14 & 0.56 & 2.18 & 0.96 & 64 & 66 & 62 & 62 \\
\hline Union City & 0.23 & 0.63 & 1.50 & 0.79 & 57 & 65 & 66 & 66 \\
\hline Walnut Creek & 0.77 & 1.75 & 3.47 & 2.00 & 29 & 39 & 48 & 44 \\
\hline West Dublin/Pleasanton & 0.10 & 0.75 & 4.46 & 1.77 & 66 & 61 & 39 & 46 \\
\hline West Oakland & 3.36 & 9.61 & 21.30 & 11.42 & 11 & 12 & 11 & 11 \\
\hline
\end{tabular}


Table X4.5

Accessibility Indices and Ranks - Alternative Network Configuration B

\begin{tabular}{|c|c|c|c|c|c|c|c|c|}
\hline \multirow[b]{2}{*}{ Station } & \multicolumn{4}{|c|}{ Accessibility Index } & \multicolumn{4}{|c|}{ Accessibility Rank } \\
\hline & $\begin{array}{r}1 / 4 \\
\text { Mile }\end{array}$ & $\begin{array}{r}1 / 2 \\
\text { Mile }\end{array}$ & 1 Mile & Avg. & $\begin{array}{r}1 / 4 \\
\text { Mile }\end{array}$ & $\begin{array}{r}1 / 2 \\
\text { Mile }\end{array}$ & $\begin{array}{r}1 \\
\text { Mile }\end{array}$ & Avg. \\
\hline 12th Street-Oakland & 7.29 & 21.06 & 45.36 & 24.57 & 8 & 6 & 7 & 6 \\
\hline 16th Street-Mission & 6.89 & 21.71 & 73.26 & 33.95 & 9 & 5 & 5 & 5 \\
\hline 19th Street-Oakland & 8.39 & 20.66 & 37.95 & 22.33 & 7 & 7 & 8 & 8 \\
\hline 24th Street-Mission & 3.72 & 19.87 & 48.45 & 24.02 & 12 & 9 & 6 & 7 \\
\hline 4th and King & 2.68 & 8.61 & 14.58 & 8.62 & 15 & 16 & 16 & 17 \\
\hline Alum Rock & 1.97 & 7.04 & 12.55 & 7.19 & 19 & 19 & 21 & 19 \\
\hline Antioch Fairgrounds & 0.35 & 1.51 & 2.47 & 1.44 & 67 & 61 & 71 & 69 \\
\hline Ashby & 2.53 & 7.61 & 13.49 & 7.88 & 17 & 18 & 18 & 18 \\
\hline Atherton & 1.28 & 2.70 & 5.19 & 3.06 & 23 & 30 & 42 & 36 \\
\hline Balboa Park & 1.30 & 4.78 & 12.85 & 6.31 & 22 & 22 & 19 & 21 \\
\hline Bayfair & 0.55 & 1.75 & 4.41 & 2.24 & 54 & 55 & 52 & 53 \\
\hline Bayshore & 0.41 & 1.45 & 3.96 & 1.94 & 63 & 64 & 59 & 60 \\
\hline Belmont & 0.60 & 2.12 & 5.43 & 2.72 & 53 & 40 & 37 & 39 \\
\hline Berkeley & 0.81 & 2.58 & 11.41 & 4.93 & 36 & 34 & 22 & 23 \\
\hline Berryessa & 0.89 & 2.74 & 5.82 & 3.15 & 34 & 29 & 35 & 35 \\
\hline Blossom Hill & 0.11 & 0.32 & 0.80 & 0.41 & 81 & 83 & 82 & 82 \\
\hline Brentwood & 0.02 & 0.08 & 0.26 & 0.12 & 89 & 88 & 88 & 88 \\
\hline Broadway & 0.78 & 1.78 & 4.90 & 2.49 & 38 & 51 & 43 & 45 \\
\hline Burlingame & 0.96 & 2.84 & 6.04 & 3.28 & 28 & 28 & 34 & 31 \\
\hline Byron & 0.03 & 0.06 & 0.16 & 0.08 & 88 & 89 & 89 & 89 \\
\hline California Avenue & 0.51 & 1.64 & 4.27 & 2.14 & 57 & 58 & 53 & 58 \\
\hline Capitol & 0.23 & 0.66 & 1.60 & 0.83 & 75 & 78 & 79 & 79 \\
\hline Castro Valley & 0.33 & 1.02 & 2.57 & 1.31 & 69 & 70 & 69 & 71 \\
\hline Civic Center & 12.26 & 43.96 & 113.64 & 56.62 & 3 & 3 & 4 & 4 \\
\hline Civic Center/SJSU & 10.10 & 16.05 & 30.97 & 19.04 & 5 & 10 & 10 & 10 \\
\hline Coliseum/OAK Airport & 1.14 & 3.40 & 7.62 & 4.05 & 26 & 23 & 28 & 26 \\
\hline College Park & 2.11 & 5.07 & 12.78 & 6.65 & 18 & 20 & 20 & 20 \\
\hline Colma & 0.72 & 2.59 & 6.21 & 3.18 & 42 & 33 & 33 & 33 \\
\hline Concord & 0.34 & 0.77 & 1.85 & 0.99 & 68 & 74 & 77 & 75 \\
\hline Daly City & 0.92 & 2.98 & 7.59 & 3.83 & 31 & 27 & 29 & 27 \\
\hline Diridon & 9.80 & 20.62 & 30.48 & 20.30 & 6 & 8 & 11 & 9 \\
\hline East Dublin/Pleasanton & 0.10 & 1.69 & 3.38 & 1.73 & 83 & 57 & 67 & 68 \\
\hline El Cerrito del Norte & 0.55 & 1.57 & 3.65 & 1.92 & 55 & 60 & 62 & 61 \\
\hline El Cerrito Plaza & 0.66 & 2.03 & 4.80 & 2.50 & 50 & 41 & 47 & 44 \\
\hline Embarcadero & 27.63 & 72.01 & 135.85 & 78.50 & 1 & 1 & 3 & 1 \\
\hline Fremont & 0.20 & 0.54 & 1.51 & 0.75 & 76 & 80 & 80 & 80 \\
\hline
\end{tabular}




\begin{tabular}{|c|c|c|c|c|c|c|c|c|}
\hline \multirow[b]{2}{*}{ Station } & \multicolumn{4}{|c|}{ Accessibility Index } & \multicolumn{4}{|c|}{ Accessibility Rank } \\
\hline & $\begin{array}{c}1 / 4 \\
\text { Mile }\end{array}$ & $\begin{array}{r}1 / 2 \\
\text { Mile }\end{array}$ & 1 Mile & Avg. & $\begin{array}{r}1 / 4 \\
\text { Mile }\end{array}$ & $\begin{array}{c}1 / 2 \\
\text { Mile }\end{array}$ & $\begin{array}{r}1 \\
\text { Mile }\end{array}$ & Avg. \\
\hline Fruitvale & 1.39 & 4.81 & 10.56 & 5.58 & 21 & 21 & 23 & 22 \\
\hline Gilroy & 0.01 & 0.04 & 0.09 & 0.04 & 90 & 90 & 90 & 90 \\
\hline Glenn Park & 2.62 & 7.69 & 19.99 & 10.10 & 16 & 17 & 15 & 15 \\
\hline Hayward & 0.38 & 1.03 & 2.54 & 1.32 & 66 & 69 & 70 & 70 \\
\hline Hayward Park & 0.95 & 2.44 & 5.21 & 2.87 & 29 & 37 & 41 & 37 \\
\hline Hillcrest Avenue & 0.07 & 0.25 & 0.62 & 0.31 & 85 & 84 & 84 & 84 \\
\hline Hillsdale & 0.83 & 2.60 & 7.97 & 3.80 & 35 & 32 & 25 & 28 \\
\hline Irvington & 0.38 & 1.04 & 3.78 & 1.73 & 65 & 68 & 61 & 67 \\
\hline Lafayette & 0.79 & 2.02 & 3.89 & 2.23 & 37 & 43 & 60 & 55 \\
\hline Lake Merritt & 4.77 & 11.96 & 22.69 & 13.14 & 10 & 12 & 12 & 12 \\
\hline Lawrence & 0.41 & 1.47 & 3.63 & 1.84 & 62 & 62 & 63 & 62 \\
\hline MacArthur & 4.24 & 11.05 & 21.83 & 12.38 & 11 & 13 & 13 & 13 \\
\hline Market Street-San Jose & 1.65 & 13.73 & 33.32 & 16.23 & 20 & 11 & 9 & 11 \\
\hline Menlo Park & 0.95 & 3.29 & 8.64 & 4.29 & 30 & 24 & 24 & 24 \\
\hline Millbrae & 0.91 & 2.52 & 6.35 & 3.26 & 33 & 35 & 31 & 32 \\
\hline Montague & 0.71 & 1.89 & 4.17 & 2.26 & 45 & 47 & 57 & 52 \\
\hline Montgomery & 10.52 & 36.98 & 147.39 & 64.97 & 4 & 4 & 1 & 3 \\
\hline Morgan Hill & 0.03 & 0.11 & 0.29 & 0.14 & 87 & 87 & 87 & 87 \\
\hline Mountain View & 0.53 & 1.69 & 4.23 & 2.15 & 56 & 56 & 56 & 57 \\
\hline North Berkeley & 3.18 & 9.77 & 13.86 & 8.94 & 14 & 14 & 17 & 16 \\
\hline North Concord & 0.19 & 0.92 & 1.93 & 1.01 & 77 & 72 & 75 & 74 \\
\hline Oakley & 0.11 & 0.23 & 0.56 & 0.30 & 80 & 85 & 85 & 85 \\
\hline Orinda & 0.69 & 1.89 & 4.27 & 2.28 & 48 & 48 & 54 & 51 \\
\hline Palo Alto & 1.10 & 2.47 & 4.48 & 2.68 & 27 & 36 & 51 & 41 \\
\hline Pittsburg & 0.14 & 0.42 & 1.07 & 0.54 & 78 & 81 & 81 & 81 \\
\hline Pleasant Hill & 1.19 & 3.25 & 5.75 & 3.40 & 24 & 26 & 36 & 30 \\
\hline Powell & 20.40 & 58.19 & 137.86 & 72.15 & 2 & 2 & 2 & 2 \\
\hline Railroad Avenue & 0.08 & 0.33 & 0.78 & 0.40 & 84 & 82 & 83 & 83 \\
\hline Redwood City & 0.45 & 1.39 & 3.47 & 1.77 & 60 & 65 & 66 & 64 \\
\hline Richmond & 0.26 & 0.74 & 1.66 & 0.89 & 73 & 77 & 78 & 78 \\
\hline Rockridge & 1.16 & 3.28 & 7.77 & 4.07 & 25 & 25 & 26 & 25 \\
\hline San Antonio & 0.50 & 1.47 & 3.29 & 1.75 & 58 & 63 & 68 & 65 \\
\hline San Bruno BART & 0.75 & 1.99 & 5.41 & 2.72 & 41 & 45 & 38 & 38 \\
\hline San Bruno CT & 0.69 & 1.85 & 5.25 & 2.59 & 47 & 49 & 40 & 43 \\
\hline San Carlos & 0.77 & 1.77 & 4.86 & 2.47 & 40 & 53 & 44 & 48 \\
\hline San Leandro & 0.60 & 2.01 & 4.85 & 2.48 & 52 & 44 & 45 & 46 \\
\hline San Martin & 0.04 & 0.14 & 0.33 & 0.17 & 86 & 86 & 86 & 86 \\
\hline San Mateo & 0.92 & 2.66 & 7.69 & 3.76 & 32 & 31 & 27 & 29 \\
\hline
\end{tabular}




\begin{tabular}{|l|r|r|r|r|r|r|r|r|}
\hline \multirow{2}{*}{\multicolumn{1}{|c|}{ Station }} & \multicolumn{4}{|c|}{ Accessibility Index } & \multicolumn{3}{c|}{ Accessibility Rank } \\
\cline { 2 - 10 } & $\begin{array}{r}\mathbf{1 / 4} \\
\text { Mile }\end{array}$ & $\begin{array}{r}\mathbf{1 / 2} \\
\text { Mile }\end{array}$ & $\begin{array}{r}\mathbf{1} \\
\text { Mile }\end{array}$ & Avg. & $\begin{array}{r}\mathbf{1 / 4} \\
\text { Mile }\end{array}$ & $\begin{array}{r}\mathbf{1 / 2} \\
\text { Mile }\end{array}$ & $\begin{array}{r}\mathbf{1} \\
\text { Mile }\end{array}$ & Avg. \\
\hline Santa Clara & 0.71 & 1.97 & 4.76 & 2.48 & 43 & 46 & 49 & 47 \\
\hline SF-22nd Street & 0.62 & 2.18 & 5.26 & 2.69 & 51 & 39 & 39 & 40 \\
\hline SFO Intl Airport & 0.44 & 1.62 & 4.83 & 2.30 & 61 & 59 & 46 & 50 \\
\hline SF-Transbay Center & 0.25 & 1.28 & 6.31 & 2.61 & 74 & 66 & 32 & 42 \\
\hline So. San Francisco BART & 0.70 & 2.40 & 6.38 & 3.16 & 46 & 38 & 30 & 34 \\
\hline So. San Francisco CT & 0.41 & 1.22 & 3.59 & 1.74 & 64 & 67 & 64 & 66 \\
\hline Sommersville Road & 0.11 & 0.58 & 2.18 & 0.96 & 79 & 79 & 74 & 77 \\
\hline South Calaveras & 0.49 & 2.02 & 4.80 & 2.44 & 59 & 42 & 48 & 49 \\
\hline South Hayward & 0.32 & 0.89 & 2.46 & 1.22 & 71 & 73 & 72 & 72 \\
\hline Sunnyvale & 0.68 & 1.78 & 4.25 & 2.24 & 49 & 52 & 55 & 54 \\
\hline Tamien & 0.71 & 1.81 & 3.99 & 2.17 & 44 & 50 & 58 & 56 \\
\hline Union City & 0.27 & 0.76 & 1.88 & 0.97 & 72 & 75 & 76 & 76 \\
\hline Walnut Creek & 0.77 & 1.76 & 3.50 & 2.01 & 39 & 54 & 65 & 59 \\
\hline Warm Springs & 0.33 & 1.00 & 2.28 & 1.21 & 70 & 71 & 73 & 73 \\
\hline West Dublin/Pleasanton & 0.11 & 0.76 & 4.49 & 1.78 & 82 & 76 & 50 & 63 \\
\hline West Oakland & 3.36 & 9.62 & 21.33 & 11.44 & 13 & 15 & 14 & 14 \\
\hline
\end{tabular}


Table X4.6

Accessibility Indices and Ranks - Alternative Future C

\begin{tabular}{|c|c|c|c|c|c|c|c|c|}
\hline \multirow[b]{2}{*}{ Station } & \multicolumn{4}{|c|}{ Accessibility Index } & \multicolumn{4}{|c|}{ Accessibility Rank } \\
\hline & $\begin{array}{r}1 / 4 \\
\text { Mile }\end{array}$ & $\begin{array}{r}1 / 2 \\
\text { Mile }\end{array}$ & 1 Mile & Avg. & $\begin{array}{r}1 / 4 \\
\text { Mile }\end{array}$ & $\begin{array}{r}1 / 2 \\
\text { Mile }\end{array}$ & $\begin{array}{r}1 \\
\text { Mile }\end{array}$ & Avg. \\
\hline 12th Street-Oakland & 7.30 & 21.06 & 45.36 & 24.57 & 8 & 6 & 7 & 6 \\
\hline 16th Street-Mission & 6.89 & 21.71 & 73.26 & 33.95 & 9 & 5 & 5 & 5 \\
\hline 19th Street-Oakland & 8.39 & 20.66 & 37.96 & 22.34 & 7 & 7 & 8 & 8 \\
\hline 24th Street-Mission & 3.73 & 19.88 & 48.46 & 24.02 & 12 & 9 & 6 & 7 \\
\hline 4th and King & 2.68 & 8.61 & 14.59 & 8.63 & 15 & 16 & 16 & 17 \\
\hline Alum Rock & 1.98 & 7.05 & 12.57 & 7.20 & 19 & 19 & 21 & 19 \\
\hline Antioch Fairgrounds & 0.35 & 1.51 & 2.47 & 1.44 & 69 & 61 & 72 & 69 \\
\hline Ashby & 2.53 & 7.61 & 13.49 & 7.88 & 17 & 18 & 18 & 18 \\
\hline Atherton & 1.32 & 2.76 & 5.30 & 3.12 & 22 & 29 & 39 & 36 \\
\hline Balboa Park & 1.31 & 4.79 & 12.86 & 6.32 & 23 & 22 & 19 & 21 \\
\hline Bayfair & 0.57 & 1.78 & 4.47 & 2.27 & 54 & 54 & 52 & 52 \\
\hline Bayshore & 0.41 & 1.45 & 3.96 & 1.94 & 63 & 65 & 59 & 60 \\
\hline Belmont & 0.62 & 2.17 & 5.51 & 2.77 & 52 & 40 & 37 & 38 \\
\hline Berkeley & 0.81 & 2.58 & 11.41 & 4.93 & 36 & 34 & 22 & 23 \\
\hline Berryessa & 0.89 & 2.74 & 5.83 & 3.15 & 34 & 30 & 35 & 35 \\
\hline Blossom Hill & 0.11 & 0.32 & 0.80 & 0.41 & 85 & 86 & 85 & 85 \\
\hline Brentwood & 0.02 & 0.08 & 0.26 & 0.12 & 92 & 91 & 91 & 91 \\
\hline Broadway & 0.79 & 1.79 & 4.91 & 2.50 & 38 & 52 & 44 & 47 \\
\hline Burlingame & 0.97 & 2.85 & 6.06 & 3.29 & 29 & 28 & 34 & 31 \\
\hline Byron & 0.03 & 0.06 & 0.16 & 0.08 & 91 & 92 & 92 & 92 \\
\hline California Avenue & 0.52 & 1.66 & 4.31 & 2.16 & 57 & 58 & 53 & 57 \\
\hline Capitol & 0.23 & 0.67 & 1.61 & 0.83 & 79 & 79 & 80 & 81 \\
\hline Castro Valley & 0.34 & 1.04 & 2.62 & 1.33 & 71 & 70 & 71 & 71 \\
\hline Centerville & 0.30 & 0.66 & 1.49 & 0.82 & 73 & 80 & 82 & 82 \\
\hline Civic Center & 12.26 & 43.96 & 113.64 & 56.62 & 3 & 3 & 4 & 4 \\
\hline Civic Center/SJSU & 10.11 & 16.06 & 30.99 & 19.05 & 5 & 10 & 10 & 10 \\
\hline Coliseum/OAK Airport & 1.15 & 3.41 & 7.64 & 4.07 & 26 & 23 & 28 & 26 \\
\hline College Park & 2.11 & 5.07 & 12.79 & 6.65 & 18 & 20 & 20 & 20 \\
\hline Colma & 0.72 & 2.60 & 6.23 & 3.19 & 42 & 33 & 33 & 33 \\
\hline Concord & 0.34 & 0.77 & 1.86 & 0.99 & 72 & 75 & 77 & 76 \\
\hline Daly City & 0.93 & 2.99 & 7.60 & 3.84 & 32 & 27 & 29 & 27 \\
\hline Diridon & 9.81 & 20.63 & 30.51 & 20.32 & 6 & 8 & 11 & 9 \\
\hline East Dublin/Pleasanton & 0.11 & 1.70 & 3.40 & 1.73 & 86 & 56 & 67 & 68 \\
\hline El Cerrito del Norte & 0.55 & 1.57 & 3.65 & 1.92 & 55 & 60 & 62 & 61 \\
\hline El Cerrito Plaza & 0.66 & 2.03 & 4.81 & 2.50 & 50 & 41 & 48 & 46 \\
\hline Embarcadero & 27.64 & 72.01 & 135.85 & 78.50 & 1 & 1 & 3 & 1 \\
\hline
\end{tabular}




\begin{tabular}{|c|c|c|c|c|c|c|c|c|}
\hline \multirow[b]{2}{*}{ Station } & \multicolumn{4}{|c|}{ Accessibility Index } & \multicolumn{4}{|c|}{ Accessibility Rank } \\
\hline & $\begin{array}{r}1 / 4 \\
\text { Mile }\end{array}$ & $\begin{array}{r}1 / 2 \\
\text { Mile }\end{array}$ & 1 Mile & Avg. & $\begin{array}{r}1 / 4 \\
\text { Mile }\end{array}$ & $\begin{array}{r}1 / 2 \\
\text { Mile }\end{array}$ & $\begin{array}{r}1 \\
\text { Mile }\end{array}$ & Avg. \\
\hline Fremont & 0.23 & 0.62 & 1.67 & 0.84 & 78 & 81 & 78 & 79 \\
\hline Fruitvale & 1.39 & 4.82 & 10.58 & 5.59 & 21 & 21 & 23 & 22 \\
\hline Gilroy & 0.01 & 0.04 & 0.09 & 0.04 & 93 & 93 & 93 & 93 \\
\hline Glenn Park & 2.62 & 7.69 & 20.00 & 10.10 & 16 & 17 & 15 & 15 \\
\hline Hayward & 0.40 & 1.08 & 2.64 & 1.37 & 66 & 68 & 69 & 70 \\
\hline Hayward Park & 0.97 & 2.47 & 5.25 & 2.90 & 30 & 37 & 42 & 37 \\
\hline Hillcrest Avenue & 0.07 & 0.25 & 0.62 & 0.31 & 88 & 87 & 87 & 87 \\
\hline Hillsdale & 0.85 & 2.64 & 8.03 & 3.84 & 35 & 32 & 25 & 28 \\
\hline Irvington & 0.40 & 1.07 & 3.86 & 1.78 & 65 & 69 & 61 & 65 \\
\hline Lafayette & 0.79 & 2.02 & 3.89 & 2.23 & 39 & 44 & 60 & 55 \\
\hline Lake Merritt & 4.78 & 11.97 & 22.70 & 13.15 & 10 & 12 & 12 & 12 \\
\hline Lawrence & 0.41 & 1.48 & 3.63 & 1.84 & 62 & 64 & 64 & 63 \\
\hline MacArthur & 4.24 & 11.06 & 21.84 & 12.38 & 11 & 13 & 13 & 13 \\
\hline Market Street-San Jose & 1.65 & 13.74 & 33.35 & 16.24 & 20 & 11 & 9 & 11 \\
\hline Menlo Park & 0.97 & 3.33 & 8.71 & 4.34 & 28 & 24 & 24 & 24 \\
\hline Millbrae & 0.92 & 2.55 & 6.39 & 3.29 & 33 & 35 & 31 & 32 \\
\hline Montague & 0.71 & 1.90 & 4.19 & 2.27 & 44 & 47 & 57 & 53 \\
\hline Montgomery & 10.52 & 36.98 & 147.39 & 64.97 & 4 & 4 & 1 & 3 \\
\hline Morgan Hill & 0.03 & 0.11 & 0.29 & 0.14 & 90 & 90 & 90 & 90 \\
\hline Mountain View & 0.53 & 1.70 & 4.24 & 2.16 & 56 & 57 & 56 & 58 \\
\hline Newark & 0.25 & 0.59 & 1.34 & 0.73 & 76 & 82 & 83 & 83 \\
\hline North Berkeley & 3.18 & 9.77 & 13.86 & 8.94 & 14 & 14 & 17 & 16 \\
\hline North Concord & 0.19 & 0.92 & 1.93 & 1.01 & 80 & 73 & 76 & 75 \\
\hline Oakley & 0.11 & 0.23 & 0.56 & 0.30 & 83 & 88 & 88 & 88 \\
\hline Orinda & 0.69 & 1.89 & 4.27 & 2.28 & 48 & 48 & 54 & 51 \\
\hline Palo Alto & 1.12 & 2.49 & 4.52 & 2.71 & 27 & 36 & 50 & 40 \\
\hline Pittsburg & 0.14 & 0.42 & 1.07 & 0.54 & 81 & 84 & 84 & 84 \\
\hline Pleasant Hill & 1.19 & 3.25 & 5.75 & 3.40 & 24 & 26 & 36 & 30 \\
\hline Powell & 20.40 & 58.19 & 137.86 & 72.15 & 2 & 2 & 2 & 2 \\
\hline Railroad Avenue & 0.08 & 0.33 & 0.79 & 0.40 & 87 & 85 & 86 & 86 \\
\hline Redwood City & 0.50 & 1.49 & 3.65 & 1.88 & 58 & 62 & 63 & 62 \\
\hline Richmond & 0.26 & 0.74 & 1.66 & 0.89 & 75 & 77 & 79 & 78 \\
\hline Rockridge & 1.16 & 3.28 & 7.77 & 4.07 & 25 & 25 & 26 & 25 \\
\hline San Antonio & 0.50 & 1.48 & 3.31 & 1.76 & 59 & 63 & 68 & 66 \\
\hline San Bruno BART & 0.76 & 2.01 & 5.45 & 2.74 & 41 & 45 & 38 & 39 \\
\hline San Bruno CT & 0.69 & 1.86 & 5.26 & 2.60 & 47 & 49 & 40 & 43 \\
\hline San Carlos & 0.81 & 1.84 & 5.00 & 2.55 & 37 & 50 & 43 & 44 \\
\hline San Leandro & 0.61 & 2.03 & 4.88 & 2.51 & 53 & 43 & 45 & 45 \\
\hline
\end{tabular}




\begin{tabular}{|l|r|r|r|r|r|r|r|r|}
\hline \multirow{2}{*}{\multicolumn{1}{|c|}{ Station }} & \multicolumn{4}{|c|}{ Accessibility Index } & \multicolumn{3}{c|}{ Accessibility Rank } \\
\cline { 2 - 10 } & $\begin{array}{r}\mathbf{1 / 4} \\
\text { Mile }\end{array}$ & $\begin{array}{r}\mathbf{1 / 2} \\
\text { Mile }\end{array}$ & $\begin{array}{r}\mathbf{1} \\
\text { Mile }\end{array}$ & Avg. & $\begin{array}{r}\mathbf{1 / 4} \\
\text { Mile }\end{array}$ & $\begin{array}{r}\mathbf{1 / 2} \\
\text { Mile }\end{array}$ & $\begin{array}{r}\mathbf{1} \\
\text { Mile }\end{array}$ & Avg. \\
\hline San Martin & 0.04 & 0.14 & 0.33 & 0.17 & 89 & 89 & 89 & 89 \\
\hline San Mateo & 0.93 & 2.69 & 7.74 & 3.79 & 31 & 31 & 27 & 29 \\
\hline Santa Clara & 0.71 & 1.97 & 4.76 & 2.48 & 43 & 46 & 49 & 48 \\
\hline SF-22nd Street & 0.62 & 2.19 & 5.26 & 2.69 & 51 & 39 & 41 & 41 \\
\hline SFO Intl Airport & 0.45 & 1.63 & 4.87 & 2.32 & 61 & 59 & 46 & 50 \\
\hline SF-Transbay Center & 0.25 & 1.28 & 6.31 & 2.62 & 77 & 66 & 32 & 42 \\
\hline So. San Francisco BART & 0.70 & 2.41 & 6.40 & 3.17 & 46 & 38 & 30 & 34 \\
\hline So. San Francisco CT & 0.41 & 1.23 & 3.61 & 1.75 & 64 & 67 & 65 & 67 \\
\hline Sommersville Road & 0.11 & 0.58 & 2.18 & 0.96 & 82 & 83 & 75 & 77 \\
\hline South Calaveras & 0.49 & 2.03 & 4.82 & 2.45 & 60 & 42 & 47 & 49 \\
\hline South Hayward & 0.36 & 0.97 & 2.62 & 1.32 & 67 & 72 & 70 & 72 \\
\hline Sunnyvale & 0.68 & 1.78 & 4.25 & 2.24 & 49 & 53 & 55 & 54 \\
\hline Tamien & 0.71 & 1.81 & 3.99 & 2.17 & 45 & 51 & 58 & 56 \\
\hline Union City & 0.35 & 0.91 & 2.21 & 1.16 & 68 & 74 & 74 & 74 \\
\hline Walnut Creek & 0.77 & 1.76 & 3.50 & 2.01 & 40 & 55 & 66 & 59 \\
\hline Warm Springs & 0.34 & 1.03 & 2.33 & 1.24 & 70 & 71 & 73 & 73 \\
\hline West Dublin/Pleasanton & 0.11 & 0.77 & 4.51 & 1.79 & 84 & 76 & 51 & 64 \\
\hline West Oakland & 3.36 & 9.62 & 21.33 & 11.44 & 13 & 15 & 14 & 14 \\
\hline Willow Road & 0.30 & 0.67 & 1.55 & 0.84 & 74 & 78 & 81 & 80 \\
\hline
\end{tabular}


Table X4.7

Spearman's Rho Significance Test for Station Rankings at Different Distance Radii

Step 1: Making Assumptions and Meeting Test Requirements

Model: Random sampling

Level of measurement is ordinal

Sampling distribution is normal

Step 2: Stating the Null Hypothesis, $\mathrm{H}_{0}$

$$
\begin{array}{ll}
H_{0}: r_{s}=0.0 & \text { No relation between sets of ranks } \\
H_{1}: r_{s} \neq 0.0 & \text { Sets of ranks are related }
\end{array}
$$

\begin{tabular}{|c|c|c|c|c|c|c|c|c|c|}
\hline \multirow{2}{*}{$\begin{array}{r}\text { Alternative: } \\
\text { Distances Compared: }{ }^{1}\end{array}$} & \multicolumn{3}{|c|}{ Alternative A } & \multicolumn{3}{|c|}{ Alternative B } & \multicolumn{3}{|c|}{ Alternative C } \\
\hline & $\mathrm{Q}-\mathrm{H}$ & $\mathrm{H}-\mathrm{M}$ & Q-M & $\mathrm{Q}-\mathrm{H}$ & $\mathrm{H}-\mathrm{M}$ & Q-M & $\mathrm{Q}-\mathrm{H}$ & $\mathrm{H}-\mathrm{M}$ & Q-M \\
\hline Sampling distribution: & \multicolumn{9}{|c|}{$t$ distribution } \\
\hline N (\# of cases/stations): & \multicolumn{3}{|c|}{74} & \multicolumn{3}{|c|}{90} & \multicolumn{3}{|c|}{93} \\
\hline Deg. of freedom ( $\mathrm{N}-2)$ : & \multicolumn{3}{|c|}{72} & \multicolumn{3}{|c|}{88} & \multicolumn{3}{|c|}{91} \\
\hline$t($ critical $):^{2}$ & \multicolumn{3}{|c|}{ \pm 1.9944} & \multicolumn{3}{|c|}{ \pm 1.9867} & \multicolumn{3}{|c|}{ \pm 1.9858} \\
\hline
\end{tabular}

Step 3: Selecting the Sampling Distribution and Establishing the Critical Region

\begin{tabular}{|c|c|c|c|c|c|c|c|c|c|}
\hline \multicolumn{2}{|c|}{ Step 4: Computing Distribution } & \multicolumn{3}{|c|}{$6 \sum D^{2}$} & \multicolumn{4}{|c|}{ N-2 } & \\
\hline \multirow{3}{*}{$\begin{array}{r}\text { Alternative: } \\
\text { stances Compared: }\end{array}$} & & & \multicolumn{2}{|c|}{$N\left(N^{2}-1\right)$} & & & & $1-r_{s}^{2}$ & \\
\hline & \multicolumn{3}{|c|}{ Alternative $\mathrm{A}$} & \multicolumn{3}{|c|}{ Alternative B } & \multicolumn{3}{|c|}{ Alternative C } \\
\hline & Q-H & H-M & Q-M & $\mathrm{Q}-\mathrm{H}$ & $\mathrm{H}-\mathrm{M}$ & Q-M & $\mathrm{Q}-\mathrm{H}$ & $\mathrm{H}-\mathrm{M}$ & Q-M \\
\hline Spearman's Rho, $r_{s}^{3}:^{3 / 4}$ & 0.963 & 0.964 & 0.909 & 0.974 & 0.964 & 0.931 & 0.973 & 0.968 & 0.935 \\
\hline Test Statistic, t(obtained): & 29.31 & 29.88 & 17.93 & 40.64 & 34.17 & 23.97 & 40.35 & 36.97 & 25.22 \\
\hline
\end{tabular}

\begin{tabular}{|c|c|c|c|c|c|c|c|c|c|}
\hline \multirow{3}{*}{$\begin{array}{r}\text { Alternative: } \\
\text { Distances Compared: }{ }^{1} \\
t(\text { critical): }\end{array}$} & \multicolumn{3}{|c|}{ Alternative $\mathrm{A}$} & \multicolumn{3}{|c|}{ Alternative B } & \multicolumn{3}{|c|}{ Alternative $\mathrm{C}$} \\
\hline & Q-H & H-M & Q-M & $Q-H$ & H-M & Q-M & Q-H & $\mathrm{H}-\mathrm{M}$ & Q-M \\
\hline & \multicolumn{3}{|c|}{ \pm 1.9944} & \multicolumn{3}{|c|}{ \pm 1.9867} & \multicolumn{3}{|c|}{ \pm 1.9858} \\
\hline Test Stat., $t$ (obtained): & 29.31 & 29.88 & 17.93 & 40.64 & 34.17 & 23.97 & 40.35 & 36.97 & 25.22 \\
\hline $\begin{array}{r}\mathrm{t} \text { (obtained) beyond } \\
\mathrm{t}(\text { critical)?: }\end{array}$ & Yes & Yes & Yes & Yes & Yes & Yes & Yes & Yes & Yes \\
\hline Reject Null Hypothesis: & Yes & Yes & Yes & Yes & Yes & Yes & Yes & Yes & Yes \\
\hline
\end{tabular}

Step 5: Interpreting Results

1 - Q-H = Quarter Mile vs. Half Mile; H-M = Half Mile vs. One Mile; Q-M = Quarter Mile vs. Half Mile

2 - $t$ (critical) based on Degrees of Freedom

$3-D=$ Difference in ranks for given station between two compared distances

$4-\sum D^{2}=$ Sum of the squares of $D$ 
Table X4.8

Increase in Accessibility from Alternative Network A to Alternative Network B

\begin{tabular}{|c|c|c|c|}
\hline Station & Sub-Regional Type & Sub-regional area & $\begin{array}{l}\text { Average Rate } \\
\text { of Increase }\end{array}$ \\
\hline 4th and King & Central City - Non-CBD & Upper Peninsula & $1752.50 \%$ \\
\hline Diridon & Central City - Non-CBD & South Bay & $1056.85 \%$ \\
\hline Tamien & Central City - Non-CBD & South Bay & $125.95 \%$ \\
\hline SF-22nd Street & Central City - Non-CBD & Upper Peninsula & $124.50 \%$ \\
\hline Fremont & Inner Ring Suburb & Coastal East Bay (Lower) & $122.39 \%$ \\
\hline Blossom Hill & Central City - Non-CBD & South Bay & $82.85 \%$ \\
\hline College Park & Central City - Non-CBD & South Bay & $80.58 \%$ \\
\hline Capitol & Central City - Non-CBD & South Bay & $79.94 \%$ \\
\hline SFO Intl Airport & Inner Ring Suburb & Upper Peninsula & $77.71 \%$ \\
\hline Santa Clara & Inner Ring Suburb & South Bay & $67.97 \%$ \\
\hline Bayshore & Central City - Non-CBD & Upper Peninsula & $53.53 \%$ \\
\hline Morgan Hill & Outer Ring Suburb & South Bay & $44.33 \%$ \\
\hline Sunnyvale & Inner Ring Suburb & South Bay & $40.33 \%$ \\
\hline Pittsburg & Outer Ring Suburb & Inland East Bay & $39.49 \%$ \\
\hline Gilroy & Outer Ring Suburb & South Bay & $34.31 \%$ \\
\hline So. San Francisco CT & Inner Ring Suburb & Upper Peninsula & $31.50 \%$ \\
\hline Lawrence & Inner Ring Suburb & South Bay & $29.98 \%$ \\
\hline Mountain View & Inner Ring Suburb & South Bay & $26.06 \%$ \\
\hline Union City & Inner Ring Suburb & Coastal East Bay (Lower) & $23.34 \%$ \\
\hline San Bruno CT & Inner Ring Suburb & Upper Peninsula & $20.14 \%$ \\
\hline Millbrae & Inner Ring Suburb & Upper Peninsula & $19.00 \%$ \\
\hline San Martin & Outer Ring Suburb & South Bay & $17.25 \%$ \\
\hline San Bruno BART & Inner Ring Suburb & Upper Peninsula & $8.91 \%$ \\
\hline South Hayward & Inner Ring Suburb & Coastal East Bay (Lower) & $8.82 \%$ \\
\hline Palo Alto & Inner Ring Suburb & Lower Peninsula & $8.15 \%$ \\
\hline San Mateo & Inner Ring Suburb & Lower Peninsula & $6.62 \%$ \\
\hline Redwood City & Inner Ring Suburb & Lower Peninsula & $6.22 \%$ \\
\hline North Concord & Outer Ring Suburb & Inland East Bay & $5.68 \%$ \\
\hline San Antonio & Inner Ring Suburb & South Bay & $5.66 \%$ \\
\hline Broadway & Inner Ring Suburb & Lower Peninsula & $5.41 \%$ \\
\hline Hayward & Inner Ring Suburb & Coastal East Bay (Lower) & $5.29 \%$ \\
\hline Hillsdale & Inner Ring Suburb & Lower Peninsula & $4.70 \%$ \\
\hline So. San Francisco BART & Inner Ring Suburb & Upper Peninsula & $3.96 \%$ \\
\hline Concord & Outer Ring Suburb & Inland East Bay & $3.24 \%$ \\
\hline California Avenue & Inner Ring Suburb & Lower Peninsula & $2.94 \%$ \\
\hline Colma & Inner Ring Suburb & Upper Peninsula & $2.87 \%$ \\
\hline
\end{tabular}




\begin{tabular}{|c|c|c|c|}
\hline Station & Sub-Regional Type & Sub-regional area & $\begin{array}{r}\text { Average Rate } \\
\text { of Increase }\end{array}$ \\
\hline Menlo Park & Inner Ring Suburb & Lower Peninsula & $2.81 \%$ \\
\hline Burlingame & Inner Ring Suburb & Lower Peninsula & $2.54 \%$ \\
\hline Castro Valley & Inner Ring Suburb & Coastal East Bay (Lower) & $2.41 \%$ \\
\hline Bayfair & Inner Ring Suburb & Coastal East Bay (Lower) & $2.04 \%$ \\
\hline Hayward Park & Inner Ring Suburb & Lower Peninsula & $1.69 \%$ \\
\hline Daly City & Inner Ring Suburb & Upper Peninsula & $1.57 \%$ \\
\hline San Leandro & Inner Ring Suburb & Coastal East Bay (Lower) & $1.29 \%$ \\
\hline Belmont & Inner Ring Suburb & Lower Peninsula & $1.23 \%$ \\
\hline Atherton & Inner Ring Suburb & Lower Peninsula & $0.97 \%$ \\
\hline San Carlos & Inner Ring Suburb & Lower Peninsula & $0.85 \%$ \\
\hline W. Dublin/Pleasanton & Outer Ring Suburb & Inland East Bay & $0.76 \%$ \\
\hline Walnut Creek & Outer Ring Suburb & Inland East Bay & $0.70 \%$ \\
\hline Balboa Park & Central City - Non-CBD & Upper Peninsula & $0.68 \%$ \\
\hline East Dublin/Pleasanton & Outer Ring Suburb & Inland East Bay & $0.60 \%$ \\
\hline Coliseum/OAK Airport & Central City - Non-CBD & Coastal East Bay (Upper) & $0.58 \%$ \\
\hline Pleasant Hill & Outer Ring Suburb & Inland East Bay & $0.55 \%$ \\
\hline Lafayette & Outer Ring Suburb & Inland East Bay & $0.47 \%$ \\
\hline Orinda & Outer Ring Suburb & Inland East Bay & $0.37 \%$ \\
\hline Fruitvale & Central City - Non-CBD & Coastal East Bay (Upper) & $0.36 \%$ \\
\hline Glenn Park & Central City - Non-CBD & Upper Peninsula & $0.35 \%$ \\
\hline Richmond & Inner Ring Suburb & Coastal East Bay (Upper) & $0.23 \%$ \\
\hline Rockridge & Central City - Non-CBD & Coastal East Bay (Upper) & $0.22 \%$ \\
\hline El Cerrito del Norte & Inner Ring Suburb & Coastal East Bay (Upper) & $0.15 \%$ \\
\hline West Oakland & Central City - Non-CBD & Coastal East Bay (Upper) & $0.14 \%$ \\
\hline El Cerrito Plaza & Inner Ring Suburb & Coastal East Bay (Upper) & $0.14 \%$ \\
\hline Lake Merritt & Central City - Non-CBD & Coastal East Bay (Upper) & $0.13 \%$ \\
\hline Berkeley & Inner Ring Suburb & Coastal East Bay (Upper) & $0.12 \%$ \\
\hline 24th Street-Mission & Central City - Non-CBD & Upper Peninsula & $0.11 \%$ \\
\hline Ashby & Inner Ring Suburb & Coastal East Bay (Upper) & $0.10 \%$ \\
\hline MacArthur & Central City - Non-CBD & Coastal East Bay (Upper) & $0.08 \%$ \\
\hline 16th Street-Mission & Central City - Non-CBD & Upper Peninsula & $0.07 \%$ \\
\hline 12th Street-Oakland & Central City - CBD & Coastal East Bay (Upper) & $0.06 \%$ \\
\hline 19th Street-Oakland & Central City - CBD & Coastal East Bay (Upper) & $0.06 \%$ \\
\hline North Berkeley & Inner Ring Suburb & Coastal East Bay (Upper) & $0.05 \%$ \\
\hline Civic Center & Central City - CBD & Upper Peninsula & $0.04 \%$ \\
\hline Montgomery & Central City - CBD & Upper Peninsula & $0.03 \%$ \\
\hline Powell & Central City - CBD & Upper Peninsula & $0.03 \%$ \\
\hline Embarcadero & Central City - CBD & Upper Peninsula & $0.02 \%$ \\
\hline
\end{tabular}


Table X4.9

Increase in Accessibility from Alternative Network A to Alternative Network C

\begin{tabular}{|c|c|c|c|}
\hline Station & Sub-Regional Type & Sub-regional area & $\begin{array}{l}\text { Avg. Rate of } \\
\text { Increase }\end{array}$ \\
\hline 4th and King & Central City - Non-CBD & Upper Peninsula & $1753.24 \%$ \\
\hline Diridon & Central City - Non-CBD & South Bay & $1057.75 \%$ \\
\hline Fremont & Inner Ring Suburb & Coastal East Bay (Lower) & $149.49 \%$ \\
\hline Tamien & Central City - Non-CBD & South Bay & $126.12 \%$ \\
\hline SF-22nd Street & Central City - Non-CBD & Upper Peninsula & $124.74 \%$ \\
\hline Blossom Hill & Central City - Non-CBD & South Bay & $83.71 \%$ \\
\hline College Park & Central City - Non-CBD & South Bay & $80.63 \%$ \\
\hline Capitol & Central City - Non-CBD & South Bay & $80.45 \%$ \\
\hline SFO Intl Airport & Inner Ring Suburb & Upper Peninsula & $79.19 \%$ \\
\hline Santa Clara & Inner Ring Suburb & South Bay & $68.09 \%$ \\
\hline Bayshore & Central City - Non-CBD & Upper Peninsula & $53.86 \%$ \\
\hline Union City & Inner Ring Suburb & Coastal East Bay (Lower) & $47.59 \%$ \\
\hline Morgan Hill & Outer Ring Suburb & South Bay & $44.85 \%$ \\
\hline Sunnyvale & Inner Ring Suburb & South Bay & $40.54 \%$ \\
\hline Pittsburg & Outer Ring Suburb & Inland East Bay & $39.56 \%$ \\
\hline Gilroy & Outer Ring Suburb & South Bay & $34.66 \%$ \\
\hline So. San Francisco CT & Inner Ring Suburb & Upper Peninsula & $32.04 \%$ \\
\hline Lawrence & Inner Ring Suburb & South Bay & $30.14 \%$ \\
\hline Mountain View & Inner Ring Suburb & South Bay & $26.34 \%$ \\
\hline San Bruno CT & Inner Ring Suburb & Upper Peninsula & $20.60 \%$ \\
\hline Millbrae & Inner Ring Suburb & Upper Peninsula & $19.86 \%$ \\
\hline San Martin & Outer Ring Suburb & South Bay & $17.67 \%$ \\
\hline South Hayward & Inner Ring Suburb & Coastal East Bay (Lower) & $17.14 \%$ \\
\hline Redwood City & Inner Ring Suburb & Lower Peninsula & $12.82 \%$ \\
\hline Hayward & Inner Ring Suburb & Coastal East Bay (Lower) & $9.83 \%$ \\
\hline San Bruno BART & Inner Ring Suburb & Upper Peninsula & $9.73 \%$ \\
\hline Palo Alto & Inner Ring Suburb & Lower Peninsula & $9.30 \%$ \\
\hline San Mateo & Inner Ring Suburb & Lower Peninsula & $7.46 \%$ \\
\hline San Antonio & Inner Ring Suburb & South Bay & $6.45 \%$ \\
\hline Broadway & Inner Ring Suburb & Lower Peninsula & $5.83 \%$ \\
\hline North Concord & Outer Ring Suburb & Inland East Bay & $5.73 \%$ \\
\hline Hillsdale & Inner Ring Suburb & Lower Peninsula & $5.64 \%$ \\
\hline So. San Francisco BART & Inner Ring Suburb & Upper Peninsula & $4.38 \%$ \\
\hline Castro Valley & Inner Ring Suburb & Coastal East Bay (Lower) & $4.28 \%$ \\
\hline San Carlos & Inner Ring Suburb & Lower Peninsula & $4.22 \%$ \\
\hline California Avenue & Inner Ring Suburb & Lower Peninsula & $3.98 \%$ \\
\hline
\end{tabular}




\begin{tabular}{|c|c|c|c|}
\hline Station & Sub-Regional Type & Sub-regional area & $\begin{array}{l}\text { Average Rate } \\
\text { of Increase }\end{array}$ \\
\hline Menlo Park & Inner Ring Suburb & Lower Peninsula & $3.84 \%$ \\
\hline Bayfair & Inner Ring Suburb & Coastal East Bay (Lower) & $3.66 \%$ \\
\hline Concord & Outer Ring Suburb & Inland East Bay & $3.31 \%$ \\
\hline Atherton & Inner Ring Suburb & Lower Peninsula & $3.20 \%$ \\
\hline Colma & Inner Ring Suburb & Upper Peninsula & $3.19 \%$ \\
\hline Belmont & Inner Ring Suburb & Lower Peninsula & $3.12 \%$ \\
\hline Burlingame & Inner Ring Suburb & Lower Peninsula & $2.99 \%$ \\
\hline Hayward Park & Inner Ring Suburb & Lower Peninsula & $2.59 \%$ \\
\hline San Leandro & Inner Ring Suburb & Coastal East Bay (Lower) & $2.16 \%$ \\
\hline Daly City & Inner Ring Suburb & Upper Peninsula & $1.74 \%$ \\
\hline W. Dublin/Pleasanton & Outer Ring Suburb & Inland East Bay & $1.32 \%$ \\
\hline E. Dublin/Pleasanton & Outer Ring Suburb & Inland East Bay & $1.07 \%$ \\
\hline Coliseum/OAK Airport & Central City - Non-CBD & Coastal East Bay (Upper) & $0.91 \%$ \\
\hline Balboa Park & Central City - Non-CBD & Upper Peninsula & $0.75 \%$ \\
\hline Walnut Creek & Outer Ring Suburb & Inland East Bay & $0.74 \%$ \\
\hline Pleasant Hill & Outer Ring Suburb & Inland East Bay & $0.57 \%$ \\
\hline Fruitvale & Central City - Non-CBD & Coastal East Bay (Upper) & $0.52 \%$ \\
\hline Lafayette & Outer Ring Suburb & Inland East Bay & $0.51 \%$ \\
\hline Orinda & Outer Ring Suburb & Inland East Bay & $0.44 \%$ \\
\hline Glenn Park & Central City - Non-CBD & Upper Peninsula & $0.39 \%$ \\
\hline Richmond & Inner Ring Suburb & Coastal East Bay (Upper) & $0.32 \%$ \\
\hline Rockridge & Central City - Non-CBD & Coastal East Bay (Upper) & $0.27 \%$ \\
\hline El Cerrito del Norte & Inner Ring Suburb & Coastal East Bay (Upper) & $0.19 \%$ \\
\hline El Cerrito Plaza & Inner Ring Suburb & Coastal East Bay (Upper) & $0.18 \%$ \\
\hline Lake Merritt & Central City - Non-CBD & Coastal East Bay (Upper) & $0.16 \%$ \\
\hline West Oakland & Central City - Non-CBD & Coastal East Bay (Upper) & $0.16 \%$ \\
\hline Berkeley & Inner Ring Suburb & Coastal East Bay (Upper) & $0.15 \%$ \\
\hline 24th Street-Mission & Central City - Non-CBD & Upper Peninsula & $0.12 \%$ \\
\hline Ashby & Inner Ring Suburb & Coastal East Bay (Upper) & $0.12 \%$ \\
\hline MacArthur & Central City - Non-CBD & Coastal East Bay (Upper) & $0.11 \%$ \\
\hline 16th Street-Mission & Central City - Non-CBD & Upper Peninsula & $0.08 \%$ \\
\hline 12th Street-Oakland & Central City - CBD & Coastal East Bay (Upper) & $0.07 \%$ \\
\hline 19th Street-Oakland & Central City - CBD & Coastal East Bay (Upper) & $0.07 \%$ \\
\hline North Berkeley & Inner Ring Suburb & Coastal East Bay (Upper) & $0.07 \%$ \\
\hline Civic Center & Central City - CBD & Upper Peninsula & $0.04 \%$ \\
\hline Montgomery & Central City - CBD & Upper Peninsula & $0.03 \%$ \\
\hline Powell & Central City - CBD & Upper Peninsula & $0.03 \%$ \\
\hline Embarcadero & Central City - CBD & Upper Peninsula & $0.02 \%$ \\
\hline
\end{tabular}


Table X4.10

Increase in Accessibility from Alternative Network B to Alternative Network C

\begin{tabular}{|c|c|c|c|}
\hline Station & Sub-Regional Type & Sub-regional area & $\begin{array}{l}\text { Average Rate } \\
\text { of Increase }\end{array}$ \\
\hline 12th Street-Oakland & Central City - CBD & Coastal East Bay (Upper) & $0.01 \%$ \\
\hline 16th Street-Mission & Central City - Non-CBD & Upper Peninsula & $0.01 \%$ \\
\hline 19th Street-Oakland & Central City - CBD & Coastal East Bay (Upper) & $0.02 \%$ \\
\hline 24th Street-Mission & Central City - Non-CBD & Upper Peninsula & $0.01 \%$ \\
\hline 4th and King & Central City - Non-CBD & Upper Peninsula & $0.04 \%$ \\
\hline Alum Rock & Inner Ring Suburb & South Bay & $0.12 \%$ \\
\hline Antioch Fairgrounds & Outer Ring Suburb & Inland East Bay & $0.02 \%$ \\
\hline Ashby & Inner Ring Suburb & Coastal East Bay (Upper) & $0.03 \%$ \\
\hline Atherton & Inner Ring Suburb & Lower Peninsula & $2.21 \%$ \\
\hline Balboa Park & Central City - Non-CBD & Upper Peninsula & $0.07 \%$ \\
\hline Bayfair & Inner Ring Suburb & Coastal East Bay (Lower) & $1.59 \%$ \\
\hline Bayshore & Central City - Non-CBD & Upper Peninsula & $0.22 \%$ \\
\hline Belmont & Inner Ring Suburb & Lower Peninsula & $1.87 \%$ \\
\hline Berkeley & Inner Ring Suburb & Coastal East Bay (Upper) & $0.03 \%$ \\
\hline Berryessa & Inner Ring Suburb & South Bay & $0.25 \%$ \\
\hline Blossom Hill & Central City - Non-CBD & South Bay & $0.47 \%$ \\
\hline Brentwood & Outer Ring Suburb & Inland East Bay & $0.11 \%$ \\
\hline Broadway & Inner Ring Suburb & Lower Peninsula & $0.41 \%$ \\
\hline Burlingame & Inner Ring Suburb & Lower Peninsula & $0.44 \%$ \\
\hline Byron & Outer Ring Suburb & Inland East Bay & $0.13 \%$ \\
\hline California Avenue & Inner Ring Suburb & Lower Peninsula & $1.01 \%$ \\
\hline Capitol & Central City - Non-CBD & South Bay & $0.29 \%$ \\
\hline Castro Valley & Inner Ring Suburb & Coastal East Bay (Lower) & $1.82 \%$ \\
\hline Civic Center & Central City - CBD & Upper Peninsula & $0.00 \%$ \\
\hline Civic Center/SJSU & Central City - CBD & South Bay & $0.05 \%$ \\
\hline Coliseum/OAK Airport & Central City - Non-CBD & Coastal East Bay (Upper) & $0.33 \%$ \\
\hline College Park & Central City - Non-CBD & South Bay & $0.03 \%$ \\
\hline Colma & Inner Ring Suburb & Upper Peninsula & $0.30 \%$ \\
\hline Concord & Outer Ring Suburb & Inland East Bay & $0.07 \%$ \\
\hline Daly City & Inner Ring Suburb & Upper Peninsula & $0.16 \%$ \\
\hline Diridon & Central City - Non-CBD & South Bay & $0.08 \%$ \\
\hline E. Dublin/Pleasanton & Outer Ring Suburb & Inland East Bay & $0.47 \%$ \\
\hline El Cerrito del Norte & Inner Ring Suburb & Coastal East Bay (Upper) & $0.04 \%$ \\
\hline El Cerrito Plaza & Inner Ring Suburb & Coastal East Bay (Upper) & $0.05 \%$ \\
\hline Embarcadero & Central City - CBD & Upper Peninsula & $0.00 \%$ \\
\hline Fremont & Inner Ring Suburb & Coastal East Bay (Lower) & $12.19 \%$ \\
\hline
\end{tabular}




\begin{tabular}{|c|c|c|c|}
\hline Station & Sub-Regional Type & Sub-regional area & $\begin{array}{l}\text { Average Rate } \\
\text { of Increase }\end{array}$ \\
\hline Fruitvale & Central City - Non-CBD & Coastal East Bay (Upper) & $0.17 \%$ \\
\hline Gilroy & Outer Ring Suburb & South Bay & $0.26 \%$ \\
\hline Glenn Park & Central City - Non-CBD & Upper Peninsula & $0.03 \%$ \\
\hline Hayward & Inner Ring Suburb & Coastal East Bay (Lower) & $4.31 \%$ \\
\hline Hayward Park & Inner Ring Suburb & Lower Peninsula & $0.89 \%$ \\
\hline Hillcrest Avenue & Outer Ring Suburb & Inland East Bay & $0.04 \%$ \\
\hline Hillsdale & Inner Ring Suburb & Lower Peninsula & $0.90 \%$ \\
\hline Irvington & Inner Ring Suburb & Coastal East Bay (Lower) & $2.61 \%$ \\
\hline Lafayette & Outer Ring Suburb & Inland East Bay & $0.04 \%$ \\
\hline Lake Merritt & Central City - Non-CBD & Coastal East Bay (Upper) & $0.04 \%$ \\
\hline Lawrence & Inner Ring Suburb & South Bay & $0.13 \%$ \\
\hline MacArthur & Central City - Non-CBD & Coastal East Bay (Upper) & $0.02 \%$ \\
\hline Market Street-San Jose & Central City - CBD & Lower Peninsula & $0.07 \%$ \\
\hline Menlo Park & Inner Ring Suburb & Lower Peninsula & $1.00 \%$ \\
\hline Millbrae & Inner Ring Suburb & Upper Peninsula & $0.73 \%$ \\
\hline Montague & Inner Ring Suburb & South Bay & $0.38 \%$ \\
\hline Montgomery & Central City - CBD & Upper Peninsula & $0.00 \%$ \\
\hline Morgan Hill & Outer Ring Suburb & South Bay & $0.36 \%$ \\
\hline Mountain View & Inner Ring Suburb & South Bay & $0.22 \%$ \\
\hline North Berkeley & Inner Ring Suburb & Coastal East Bay (Upper) & $0.02 \%$ \\
\hline North Concord & Outer Ring Suburb & Inland East Bay & $0.05 \%$ \\
\hline Oakley & Outer Ring Suburb & Inland East Bay & $0.07 \%$ \\
\hline Orinda & Outer Ring Suburb & Inland East Bay & $0.06 \%$ \\
\hline Palo Alto & Inner Ring Suburb & Lower Peninsula & $1.07 \%$ \\
\hline Pittsburg & Outer Ring Suburb & Inland East Bay & $0.05 \%$ \\
\hline Pleasant Hill & Outer Ring Suburb & Inland East Bay & $0.02 \%$ \\
\hline Powell & Central City - CBD & Upper Peninsula & $0.00 \%$ \\
\hline Railroad Avenue & Outer Ring Suburb & Inland East Bay & $0.09 \%$ \\
\hline Redwood City & Inner Ring Suburb & Lower Peninsula & $6.21 \%$ \\
\hline Richmond & Inner Ring Suburb & Coastal East Bay (Upper) & $0.09 \%$ \\
\hline Rockridge & Central City - Non-CBD & Coastal East Bay (Upper) & $0.05 \%$ \\
\hline San Antonio & Inner Ring Suburb & South Bay & $0.75 \%$ \\
\hline San Bruno BART & Inner Ring Suburb & Upper Peninsula & $0.75 \%$ \\
\hline San Bruno CT & Inner Ring Suburb & Upper Peninsula & $0.38 \%$ \\
\hline San Carlos & Inner Ring Suburb & Lower Peninsula & $3.34 \%$ \\
\hline San Leandro & Inner Ring Suburb & Coastal East Bay (Lower) & $0.86 \%$ \\
\hline San Martin & Outer Ring Suburb & South Bay & $0.37 \%$ \\
\hline San Mateo & Inner Ring Suburb & Lower Peninsula & $0.80 \%$ \\
\hline
\end{tabular}




\begin{tabular}{|l|l|l|r|}
\hline Station & Sub-Regional Type & Sub-regional area & $\begin{array}{r}\text { Average Rate } \\
\text { of Increase }\end{array}$ \\
\hline Santa Clara & Inner Ring Suburb & South Bay & $0.07 \%$ \\
\hline SF-22nd Street & Central City - Non-CBD & Upper Peninsula & $0.11 \%$ \\
\hline SFO Intl Airport & Inner Ring Suburb & Upper Peninsula & $0.83 \%$ \\
\hline SF-Transbay Center & Central City - CBD & Upper Peninsula & $0.10 \%$ \\
\hline So. San Francisco BART & Inner Ring Suburb & Upper Peninsula & $0.41 \%$ \\
\hline So. San Francisco CT & Inner Ring Suburb & Upper Peninsula & $0.40 \%$ \\
\hline Sommersville Road & Outer Ring Suburb & Inland East Bay & $0.02 \%$ \\
\hline South Calaveras & Inner Ring Suburb & South Bay & $0.47 \%$ \\
\hline South Hayward & Inner Ring Suburb & Coastal East Bay (Lower) & $7.65 \%$ \\
\hline Sunnyvale & Inner Ring Suburb & South Bay & $0.15 \%$ \\
\hline Tamien & Central City - Non-CBD & South Bay & $0.07 \%$ \\
\hline Union City & Inner Ring Suburb & Coastal East Bay (Lower) & $19.65 \%$ \\
\hline Walnut Creek & Outer Ring Suburb & Inland East Bay & $0.04 \%$ \\
\hline Warm Springs & Inner Ring Suburb & Coastal East Bay (Lower) & $2.47 \%$ \\
\hline W. Dublin/Pleasanton & Outer Ring Suburb & Inland East Bay & $0.56 \%$ \\
\hline West Oakland & Central City - Non-CBD & Coastal East Bay (Upper) & $0.02 \%$ \\
\hline
\end{tabular}


Table X4.11

Percent of Station Surrounding Areas That Are Low Density Res. - $1 / 4$ Mile Radius

\begin{tabular}{|c|c|c|c|c|c|}
\hline Rank & Station & $\begin{array}{l}\text { Percent of } \\
\text { Surrounding } \\
\text { Area that is } \\
\text { Low Density } \\
\text { Residential }\end{array}$ & Rank & Station & $\begin{array}{l}\text { Percent of } \\
\text { Surrounding } \\
\text { Area that is } \\
\text { Low Density } \\
\text { Residential }\end{array}$ \\
\hline 1 & Atherton & $96.7 \%$ & 30 & Willow Road & $16.5 \%$ \\
\hline 2 & North Berkeley & $52.3 \%$ & 31 & Millbrae & $16.1 \%$ \\
\hline 3 & San Bruno CT & $51.0 \%$ & 32 & Capitol & $15.4 \%$ \\
\hline 4 & Hayward Park & $45.6 \%$ & 33 & SF-22nd St & $14.9 \%$ \\
\hline 5 & Glenn Park & $45.2 \%$ & 34 & 16th St-Mission & $12.6 \%$ \\
\hline 6 & North Concord & $37.7 \%$ & 35 & Centerville & $12.5 \%$ \\
\hline 7 & El Cerrito Plaza & $37.1 \%$ & 36 & Orinda & $12.4 \%$ \\
\hline 8 & San Carlos & $36.2 \%$ & 37 & Broadway & $10.6 \%$ \\
\hline 9 & Antioch Fairgrounds & $32.4 \%$ & 38 & Sommersville Road & $10.0 \%$ \\
\hline 10 & Castro Valley & $31.6 \%$ & 39 & Daly City & $9.5 \%$ \\
\hline 11 & El Cerrito del Norte & $28.7 \%$ & 40 & Brentwood & $9.4 \%$ \\
\hline 12 & 25th St-Mission & $28.5 \%$ & 41 & Railroad Avenue & $9.2 \%$ \\
\hline 13 & Concord & $28.5 \%$ & 42 & Tamien & $8.3 \%$ \\
\hline 14 & Sunnyvale & $28.4 \%$ & 43 & Coliseum/OAK Airport & $8.0 \%$ \\
\hline 15 & San Bruno BART & $28.2 \%$ & 44 & Newark & $7.7 \%$ \\
\hline 16 & Alum Rock & $28.0 \%$ & 45 & Blossom Hill & $7.2 \%$ \\
\hline 17 & Bayfair & $27.9 \%$ & 46 & San Antonio & $5.8 \%$ \\
\hline 18 & Balboa Park & $27.2 \%$ & 47 & Union City & $5.4 \%$ \\
\hline 19 & Gilroy & $25.8 \%$ & 48 & Menlo Park & $4.5 \%$ \\
\hline 20 & Hillsdale & $25.6 \%$ & 49 & Burlingame & $3.8 \%$ \\
\hline 21 & Bayshore & $25.6 \%$ & 50 & Berryessa & $2.6 \%$ \\
\hline 22 & S. San Francisco BART & $24.8 \%$ & 51 & San Leandro & $2.0 \%$ \\
\hline 23 & South Hayward & $24.5 \%$ & 52 & Montague & $1.1 \%$ \\
\hline 24 & Mountain View & $22.2 \%$ & 53 & Richmond & $0.6 \%$ \\
\hline 25 & Hillcrest Avenue & $18.8 \%$ & 54 & Walnut Creek & $0.5 \%$ \\
\hline 26 & Irvington & $18.0 \%$ & 55 & Ashby & $0.3 \%$ \\
\hline 27 & Lafayette & $17.9 \%$ & 56 & Pittsburg & $0.1 \%$ \\
\hline 28 & College Park & $17.9 \%$ & 57 & Oakley & $0.0 \%$ \\
\hline 29 & Belmont & $17.6 \%$ & 58 & Pleasant Hill & $0.0 \%$ \\
\hline
\end{tabular}


Table X4.12

Percent of Station Surrounding Areas That Are Low Density Res. - 1/2 Mile Radius

\begin{tabular}{|c|c|c|c|c|c|}
\hline Rank & Station & $\begin{array}{l}\text { Percent of } \\
\text { Surrounding } \\
\text { Area that is } \\
\text { Low Density } \\
\text { Residential }\end{array}$ & Rank & Station & $\begin{array}{r}\text { Percent of } \\
\text { Surrounding } \\
\text { Area that is } \\
\text { Low Density } \\
\text { Residential }\end{array}$ \\
\hline 1 & Atherton & $83.0 \%$ & 39 & Capitol & $19.4 \%$ \\
\hline 2 & Glenn Park & $54.2 \%$ & 40 & San Leandro & $18.1 \%$ \\
\hline 3 & San Bruno CT & $48.5 \%$ & 41 & Richmond & $18.0 \%$ \\
\hline 4 & North Berkeley & $47.4 \%$ & 42 & Berryessa & $17.5 \%$ \\
\hline 5 & Hillcrest Avenue & $44.2 \%$ & 43 & Fremont & $17.3 \%$ \\
\hline 6 & El Cerrito del Norte & $44.2 \%$ & 44 & SF-22nd Street & $17.1 \%$ \\
\hline 7 & El Cerrito Plaza & $42.1 \%$ & 45 & Willow Road & $17.0 \%$ \\
\hline 8 & 24th St-Mission & $39.2 \%$ & 46 & Millbrae & $16.6 \%$ \\
\hline 9 & Orinda & $38.2 \%$ & 47 & San Bruno BART & $16.2 \%$ \\
\hline 10 & Antioch Fairgrounds & $38.1 \%$ & 48 & Daly City & $16.0 \%$ \\
\hline 11 & Balboa Park & $38.0 \%$ & 49 & Coliseum/OAK Apt. & $15.7 \%$ \\
\hline 12 & Hayward Park & $38.0 \%$ & 50 & South Hayward & $15.0 \%$ \\
\hline 13 & Belmont & $37.7 \%$ & 51 & Newark & $14.8 \%$ \\
\hline 14 & San Carlos & $36.2 \%$ & 52 & Blossom Hill & $14.8 \%$ \\
\hline 15 & Gilroy & $35.1 \%$ & 53 & Ashby & $12.7 \%$ \\
\hline 16 & Irvington & $33.4 \%$ & 54 & Walnut Creek & $12.4 \%$ \\
\hline 17 & Castro Valley & $33.0 \%$ & 55 & 16th St-Mission & $11.8 \%$ \\
\hline 18 & Bayfair & $32.8 \%$ & 56 & College Park & $11.5 \%$ \\
\hline 19 & Hillsdale & $32.6 \%$ & 57 & Pittsburg & $11.2 \%$ \\
\hline 20 & North Concord & $32.6 \%$ & 58 & Oakley & $11.1 \%$ \\
\hline 21 & Centerville & $32.6 \%$ & 59 & Sommersville Road & $10.2 \%$ \\
\hline 22 & San Antonio & $30.9 \%$ & 60 & Civic Center/SJSU & $9.4 \%$ \\
\hline 23 & Alum Rock & $29.9 \%$ & 61 & Lawrence & $8.4 \%$ \\
\hline 24 & Sunnyvale & $29.8 \%$ & 62 & Berkeley & $8.1 \%$ \\
\hline 25 & S. San Francisco BART & $29.1 \%$ & 63 & Pleasant Hill & $8.1 \%$ \\
\hline 26 & Tamien & $28.8 \%$ & 64 & Montague & $7.7 \%$ \\
\hline 27 & Concord & $28.5 \%$ & 65 & San Mateo & $6.8 \%$ \\
\hline 28 & Burlingame & $26.9 \%$ & 66 & Warm Springs & $6.7 \%$ \\
\hline 29 & Mountain View & $26.3 \%$ & 67 & Colma & $5.5 \%$ \\
\hline 30 & Brentwood & $26.2 \%$ & 68 & South Calaveras & $5.3 \%$ \\
\hline 31 & Bayshore & $24.4 \%$ & 69 & Palo Alto & $4.5 \%$ \\
\hline 32 & California Avenue & $23.3 \%$ & 70 & So. San Francisco CT & $3.1 \%$ \\
\hline 33 & Menlo Park & $23.3 \%$ & 71 & Redwood City & $1.6 \%$ \\
\hline 34 & Railroad Avenue & $23.0 \%$ & 72 & Civic Center & $0.1 \%$ \\
\hline 35 & Lafayette & $22.6 \%$ & 73 & Byron & $0.1 \%$ \\
\hline
\end{tabular}




\begin{tabular}{|c|c|c|c|c|c|}
\hline Rank & Station & $\begin{array}{l}\text { Percent of } \\
\text { Surrounding } \\
\text { Area that is } \\
\text { Low Density } \\
\text { Residential }\end{array}$ & Rank & Station & $\begin{array}{r}\text { Percent of } \\
\text { Surrounding } \\
\text { Area that is } \\
\text { Low Density } \\
\text { Residential }\end{array}$ \\
\hline 36 & Rockridge & $22.4 \%$ & 74 & Diridon & $0.1 \%$ \\
\hline 37 & Union City & $21.6 \%$ & 75 & SFO Intl Airport & $0.1 \%$ \\
\hline 38 & Broadway & $21.6 \%$ & & & \\
\hline
\end{tabular}


Table X4.13

Percent of Station Surrounding Areas That Are Low Density Residential - 1 Mile Radius

\begin{tabular}{|c|c|c|c|c|c|}
\hline Rank & Station & $\begin{array}{l}\text { Percent of } \\
\text { Surrounding } \\
\text { Area that is } \\
\text { Low Density } \\
\text { Residential }\end{array}$ & Rank & Station & $\begin{array}{r}\text { Percent of } \\
\text { Surrounding } \\
\text { Area that is } \\
\text { Low Density } \\
\text { Residential }\end{array}$ \\
\hline 1 & Atherton & $63.4 \%$ & 36 & Mountain View & $27.5 \%$ \\
\hline 2 & Irvington & $58.2 \%$ & 37 & Rockridge & $27.2 \%$ \\
\hline 3 & Hillcrest Avenue & $53.0 \%$ & 38 & Burlingame & $27.2 \%$ \\
\hline 4 & Balboa Park & $51.9 \%$ & 39 & Berryessa & $26.7 \%$ \\
\hline 5 & Orinda & $51.8 \%$ & 40 & Berkeley & $26.5 \%$ \\
\hline 6 & Menlo Park & $50.5 \%$ & 41 & San Antonio & $26.2 \%$ \\
\hline 7 & El Cerrito del Norte & $50.1 \%$ & 42 & Daly City & $25.5 \%$ \\
\hline 8 & Glenn Park & $50.0 \%$ & 43 & Millbrae & $25.1 \%$ \\
\hline 9 & Centerville & $49.7 \%$ & 44 & Willow Road & $25.1 \%$ \\
\hline 10 & Hillsdale & $48.5 \%$ & 45 & Civic Center/SJSU & $24.4 \%$ \\
\hline 11 & Hayward Park & $46.0 \%$ & 46 & South Calaveras & $24.0 \%$ \\
\hline 12 & Union City & $44.6 \%$ & 47 & Palo Alto & $24.0 \%$ \\
\hline 13 & California Avenue & $44.2 \%$ & 48 & San Bruno BART & $22.3 \%$ \\
\hline 14 & Richmond & $43.6 \%$ & 49 & 16th St-Mission & $21.8 \%$ \\
\hline 15 & Antioch Fairgrounds & $43.0 \%$ & 50 & Blossom Hill & $21.5 \%$ \\
\hline 16 & Lafayette & $42.8 \%$ & 51 & Warm Springs & $21.3 \%$ \\
\hline 17 & El Cerrito Plaza & $42.8 \%$ & 52 & Broadway & $19.9 \%$ \\
\hline 18 & Brentwood & $40.7 \%$ & 53 & Montague & $19.5 \%$ \\
\hline 19 & North Berkeley & $40.4 \%$ & 54 & Oakley & $19.3 \%$ \\
\hline 20 & San Bruno CT & $39.9 \%$ & 55 & Fremont & $19.2 \%$ \\
\hline 21 & San Mateo & $39.1 \%$ & 56 & Walnut Creek & $19.1 \%$ \\
\hline 22 & San Carlos & $38.7 \%$ & 57 & Bayshore & $19.0 \%$ \\
\hline 23 & 24th St-Mission & $38.3 \%$ & 58 & College Park & $19.0 \%$ \\
\hline 24 & San Leandro & $36.6 \%$ & 59 & Sommersville Road & $18.8 \%$ \\
\hline 25 & Tamien & $35.2 \%$ & 60 & North Concord & $18.5 \%$ \\
\hline 26 & Castro Valley & $34.0 \%$ & 61 & Pittsburg & $18.2 \%$ \\
\hline 27 & Sunnyvale & $33.6 \%$ & 62 & Coliseum/OAK Apt & $18.0 \%$ \\
\hline 28 & Gilroy & $32.7 \%$ & 63 & Newark & $17.7 \%$ \\
\hline 29 & Concord & $31.1 \%$ & 64 & Ashby & $17.3 \%$ \\
\hline 30 & Alum Rock & $30.8 \%$ & 65 & Diridon & $16.9 \%$ \\
\hline 31 & Capitol & $30.1 \%$ & 66 & Lawrence & $16.6 \%$ \\
\hline 32 & Belmont & $29.9 \%$ & 67 & Redwood City & $16.3 \%$ \\
\hline 33 & Bayfair & $29.6 \%$ & 68 & South Hayward & $14.8 \%$ \\
\hline 34 & S. San Francisco BART & $28.7 \%$ & 69 & W. Dublin/Pleasanton & $12.1 \%$ \\
\hline 35 & Railroad Avenue & $28.4 \%$ & 70 & Hayward & $11.7 \%$ \\
\hline
\end{tabular}




\begin{tabular}{|c|c|c|c|c|c|}
\hline Rank & Station & $\begin{array}{l}\text { Percent of } \\
\text { Surrounding } \\
\text { Area that is } \\
\text { Low Density } \\
\text { Residential }\end{array}$ & Rank & Station & $\begin{array}{r}\text { Percent of } \\
\text { Surrounding } \\
\text { Area that is } \\
\text { Low Density } \\
\text { Residential }\end{array}$ \\
\hline 71 & Market St.-San Jose & $11.6 \%$ & 79 & Montgomery & $1.7 \%$ \\
\hline 72 & SFO Intl. Airport & $11.4 \%$ & 80 & Embarcadero & $1.5 \%$ \\
\hline 73 & So. San Francisco CT & $11.2 \%$ & 81 & Morgan Hill & $1.5 \%$ \\
\hline 74 & Colma & $10.8 \%$ & 82 & Byron & $1.4 \%$ \\
\hline 75 & SF-22nd St & $10.1 \%$ & 83 & Santa Clara & $1.4 \%$ \\
\hline 76 & Pleasant Hill & $9.6 \%$ & 84 & SF-Transbay Center & $0.9 \%$ \\
\hline 77 & Fruitvale & $6.7 \%$ & 85 & 4th and King & $0.9 \%$ \\
\hline 78 & Civic Center & $2.4 \%$ & 86 & Powell & $0.5 \%$ \\
\hline
\end{tabular}


Table X4.14

Generalized Opportunities for TOD at Individual Stations

\begin{tabular}{|c|c|c|c|c|c|c|c|}
\hline \multirow[b]{2}{*}{ Station } & \multicolumn{4}{|c|}{ Accessibility Index } & \multirow{2}{*}{\begin{tabular}{|r|}
$\%$ of Area \\
Surrounding, \\
Low-Den. Res.
\end{tabular}} & \multirow[b]{2}{*}{ Score } & \multirow{2}{*}{$\begin{array}{l}\text { Score } \\
\text { Rank }\end{array}$} \\
\hline & Alt. A & Alt. B & Alt. C & Sum & & & \\
\hline Embarcadero & 78.48 & 78.50 & 78.50 & 235.48 & \begin{tabular}{|l|}
$0.00 \%$ \\
\end{tabular} & 234.30 & 1 \\
\hline Powell & 72.13 & 72.15 & 72.15 & 216.43 & $0.00 \%$ & 216.05 & 2 \\
\hline Montgomery & 64.95 & 64.97 & 64.97 & 194.88 & $0.00 \%$ & 193.79 & 3 \\
\hline Civic Center & 56.60 & 56.62 & 56.62 & 169.84 & $0.12 \%$ & 168.44 & 4 \\
\hline 16th Street-Mission & 33.93 & 33.95 & 33.95 & 101.83 & $11.85 \%$ & 86.13 & 5 \\
\hline 12th Street-Oakland & 24.56 & 24.57 & 24.57 & 73.70 & $0.00 \%$ & 73.70 & 6 \\
\hline 19th Street-Oakland & 22.32 & 22.33 & 22.34 & 66.99 & $0.00 \%$ & 66.99 & 7 \\
\hline 24th Street-Mission & 23.99 & 24.02 & 24.02 & 72.03 & $39.24 \%$ & 46.57 & 8 \\
\hline Diridion & 1.75 & 20.30 & 20.32 & 42.37 & $0.10 \%$ & 39.97 & 9 \\
\hline Lake Merritt & 13.13 & 13.14 & 13.15 & 39.42 & $0.00 \%$ & 39.42 & 10 \\
\hline MacArthur & 12.37 & 12.38 & 12.38 & 37.12 & $0.00 \%$ & 37.12 & 11 \\
\hline Civic Center/SJSU & -- & 19.04 & 19.05 & 38.09 & $9.40 \%$ & 33.80 & 12 \\
\hline West Oakland & 11.42 & 11.44 & 11.44 & 34.30 & $0.00 \%$ & 34.30 & 13 \\
\hline Market St.-San Jose & -- & 16.23 & 16.24 & 32.48 & $0.00 \%$ & 31.23 & 14 \\
\hline Ashby & 7.87 & 7.88 & 7.88 & 23.62 & $12.68 \%$ & 21.24 & 15 \\
\hline 4th and King & 0.47 & 8.62 & 8.63 & 17.71 & $0.00 \%$ & 17.66 & 16 \\
\hline \begin{tabular}{|l|} 
Fruitvale \\
\end{tabular} & 5.57 & 5.58 & 5.59 & 16.74 & $0.00 \%$ & 16.37 & 17 \\
\hline College Park & 3.68 & 6.65 & 6.65 & 16.99 & $11.52 \%$ & 14.25 & 18 \\
\hline North Berkeley & 8.93 & 8.94 & 8.94 & 26.81 & $47.38 \%$ & 14.30 & 19 \\
\hline Glenn Park & 10.06 & 10.10 & 10.10 & 30.26 & $54.21 \%$ & 15.19 & 20 \\
\hline Berkeley & 4.93 & 4.93 & 4.93 & 14.79 & $8.13 \%$ & 13.08 & 21 \\
\hline Balboa Park & 6.27 & 6.31 & 6.32 & 18.90 & $38.01 \%$ & 11.52 & 22 \\
\hline San Mateo & 3.52 & 3.76 & 3.79 & 11.07 & $6.77 \%$ & 9.37 & 23 \\
\hline Coliseum/OAK Apt. & 4.03 & 4.05 & 4.07 & 12.15 & $15.71 \%$ & 10.46 & 24 \\
\hline Alum Rock & -- & 7.19 & 7.20 & 14.39 & $29.88 \%$ & 10.13 & 25 \\
\hline Menlo Park & 4.18 & 4.29 & 4.34 & 12.81 & $23.29 \%$ & 9.46 & 26 \\
\hline Daly City & 3.77 & 3.83 & 3.84 & 11.45 & $15.95 \%$ & 9.50 & 27 \\
\hline \begin{tabular}{|l|} 
Rockridge \\
\end{tabular} & 4.06 & 4.07 & 4.07 & 12.20 & $22.36 \%$ & 10.18 & 28 \\
\hline Pleasant Hill & 3.38 & 3.40 & 3.40 & 10.18 & $8.08 \%$ & 9.58 & 29 \\
\hline Colma & 3.09 & 3.18 & 3.19 & 9.45 & $5.55 \%$ & 8.93 & 30 \\
\hline Millbrae & 2.74 & 3.26 & 3.29 & 9.29 & $16.58 \%$ & 7.50 & 31 \\
\hline Hillsdale & 3.63 & 3.80 & 3.84 & 11.27 & $32.63 \%$ & 7.27 & 32 \\
\hline Palo Alto & 2.48 & 2.68 & 2.71 & 7.87 & $4.48 \%$ & 7.12 & 33 \\
\hline Burlingame & 3.20 & 3.28 & 3.29 & 9.77 & $26.94 \%$ & 7.88 & 34 \\
\hline San Bruno BART & 2.50 & 2.72 & 2.74 & 7.95 & $16.22 \%$ & 6.18 & 35 \\
\hline So. San Francisco BART & 3.04 & 3.16 & 3.17 & 9.37 & $29.13 \%$ & 6.79 & 36 \\
\hline Santa Clara & 1.48 & 2.48 & 2.48 & 6.44 & $0.00 \%$ & 6.41 & 37 \\
\hline San Leandro & 2.45 & 2.48 & 2.51 & 7.44 & $18.10 \%$ & 6.04 & 38 \\
\hline SFO Intl Airport & 1.29 & 2.30 & 2.32 & 5.91 & $0.06 \%$ & 5.68 & 39 \\
\hline Broadway & 2.36 & 2.49 & 2.50 & 7.34 & $21.62 \%$ & 6.07 & 40 \\
\hline
\end{tabular}




\begin{tabular}{|c|c|c|c|c|c|c|c|}
\hline \multirow[b]{2}{*}{ Station } & \multicolumn{4}{|c|}{ Accessibility Index } & \multirow{2}{*}{$\begin{array}{r}\text { \% of Area } \\
\text { Surrounding, } \\
\text { Low-Den. } \\
\text { Res. }\end{array}$} & \multirow[b]{2}{*}{ Score } & \multirow{2}{*}{$\begin{array}{l}\text { Score } \\
\text { Rank }\end{array}$} \\
\hline & Alt. A & Alt. B & Alt. C & Sum & & & \\
\hline SF-22nd Street & 1.20 & 2.69 & 2.69 & 6.58 & $17.10 \%$ & 5.65 & 41 \\
\hline W. Dublin/Pleasanton & 1.77 & 1.78 & 1.79 & 5.35 & $0.00 \%$ & 5.13 & 42 \\
\hline Hayward Park & 2.82 & 2.87 & 2.90 & 8.59 & $37.95 \%$ & 4.88 & 43 \\
\hline Walnut Creek & 2.00 & 2.01 & 2.01 & 6.02 & $12.40 \%$ & 5.38 & 44 \\
\hline Redwood City & 1.67 & 1.77 & 1.88 & 5.32 & $1.61 \%$ & 5.00 & 45 \\
\hline SF-Transbay Center & -- & 2.61 & 2.62 & 5.23 & $0.00 \%$ & 5.21 & 46 \\
\hline Berryessa & -- & 3.15 & 3.15 & 6.30 & $17.52 \%$ & 5.32 & 47 \\
\hline E. Dublin/Pleasanton & 1.72 & 1.73 & 1.73 & 5.18 & $0.00 \%$ & 5.18 & 48 \\
\hline Lafayette & 2.22 & 2.23 & 2.23 & 6.68 & $22.57 \%$ & 4.83 & 49 \\
\hline Belmont & 2.68 & 2.72 & 2.77 & 8.17 & $37.72 \%$ & 5.85 & 50 \\
\hline California Avenue & 2.08 & 2.14 & 2.16 & 6.38 & $23.34 \%$ & 4.95 & 51 \\
\hline San Carlos & 2.45 & 2.47 & 2.55 & 7.46 & $36.21 \%$ & 4.70 & 52 \\
\hline Lawrence & 1.41 & 1.84 & 1.84 & 5.09 & $8.37 \%$ & 4.67 & 53 \\
\hline So. San Francisco CT & 1.32 & 1.74 & 1.75 & 4.81 & $3.06 \%$ & 4.59 & 54 \\
\hline South Calaveras & -- & 2.44 & 2.45 & 4.88 & $5.30 \%$ & 4.41 & 55 \\
\hline Bayfair & 2.19 & 2.24 & 2.27 & 6.70 & $32.78 \%$ & 4.68 & 56 \\
\hline Mountain View & 1.71 & 2.15 & 2.16 & 6.01 & $26.26 \%$ & 4.49 & 57 \\
\hline El Cerrito Plaza & 2.49 & 2.50 & 2.50 & 7.49 & $42.05 \%$ & 4.45 & 58 \\
\hline Sunnyvale & 1.59 & 2.24 & 2.24 & 6.07 & $29.84 \%$ & 4.21 & 59 \\
\hline Orinda & 2.27 & 2.28 & 2.28 & 6.83 & $38.19 \%$ & 4.50 & 60 \\
\hline Montague & -- & 2.26 & 2.27 & 4.53 & $7.70 \%$ & 4.10 & 61 \\
\hline Hayward & 1.25 & 1.32 & 1.37 & 3.94 & $0.00 \%$ & 3.79 & 62 \\
\hline Bayshore & 1.26 & 1.94 & 1.94 & 5.14 & $24.43 \%$ & 3.96 & 63 \\
\hline San Bruno CT & 2.16 & 2.59 & 2.60 & 7.36 & $48.48 \%$ & 3.94 & 64 \\
\hline Tamien & 0.96 & 2.17 & 2.17 & 5.30 & $28.84 \%$ & 4.02 & 65 \\
\hline San Antonio & 1.66 & 1.75 & 1.76 & 5.17 & $30.88 \%$ & 4.09 & 66 \\
\hline El Cerrito del Norte & 1.92 & 1.92 & 1.92 & 5.77 & $44.17 \%$ & 3.41 & 67 \\
\hline South Hayward & 1.12 & 1.22 & 1.32 & 3.66 & $15.02 \%$ & 3.00 & 68 \\
\hline Castro Valley & 1.28 & 1.31 & 1.33 & 3.92 & $33.02 \%$ & 2.63 & 69 \\
\hline Irvington & -- & 1.73 & 1.78 & 3.51 & $33.41 \%$ & 2.23 & 70 \\
\hline Union City & 0.79 & 0.97 & 1.16 & 2.91 & $21.63 \%$ & 2.22 & 71 \\
\hline Warm Springs & -- & 1.21 & 1.24 & 2.44 & $6.72 \%$ & 2.21 & 72 \\
\hline Richmond & 0.88 & 0.89 & 0.89 & 2.66 & $18.05 \%$ & 2.11 & 73 \\
\hline Concord & 0.96 & 0.99 & 0.99 & 2.93 & $28.49 \%$ & 2.07 & 74 \\
\hline North Concord & 0.96 & 1.01 & 1.01 & 2.99 & $32.62 \%$ & 2.10 & 75 \\
\hline Antioch Fairgrounds & -- & 1.44 & 1.44 & 2.89 & $38.08 \%$ & 1.79 & 76 \\
\hline Sommersville Road & -- & 0.96 & 0.96 & 1.92 & $10.21 \%$ & 1.67 & 77 \\
\hline Capitol & 0.46 & 0.83 & 0.83 & 2.13 & $19.39 \%$ & 1.67 & 78 \\
\hline Fremont & 0.34 & 0.75 & 0.84 & 1.93 & $17.26 \%$ & 1.69 & 79 \\
\hline Atherton & 3.03 & 3.06 & 3.12 & 9.21 & $82.96 \%$ & 1.75 & 80 \\
\hline
\end{tabular}




\begin{tabular}{|c|c|c|c|c|c|c|c|}
\hline \multirow[b]{2}{*}{ Station } & \multicolumn{4}{|c|}{ Accessibility Index } & \multirow{2}{*}{$\begin{array}{r}\% \text { of Area } \\
\text { Surrounding, } \\
\text { Low-Den. } \\
\text { Res. }\end{array}$} & \multirow[b]{2}{*}{ Score } & \multirow{2}{*}{$\begin{array}{l}\text { Score } \\
\text { Rank }\end{array}$} \\
\hline & Alt. A & Alt. B & Alt. C & Sum & & & \\
\hline Pittsburg & 0.39 & 0.54 & 0.54 & 1.47 & $11.19 \%$ & 1.32 & 81 \\
\hline Blossom Hill & 0.22 & 0.41 & 0.41 & 1.05 & $14.79 \%$ & 0.89 & 82 \\
\hline Willow Road & -- & -- & 0.84 & 0.84 & $17.03 \%$ & 0.68 & 83 \\
\hline Newark & -- & -- & 0.73 & 0.73 & $14.85 \%$ & 0.63 & 84 \\
\hline Railroad Avenue & -- & 0.40 & 0.40 & 0.80 & $22.96 \%$ & 0.64 & 85 \\
\hline Centerville & -- & -- & 0.82 & 0.82 & $32.58 \%$ & 0.56 & 86 \\
\hline Oakley & -- & 0.30 & 0.30 & 0.60 & $11.09 \%$ & 0.54 & 87 \\
\hline San Martin & 0.15 & 0.17 & 0.17 & 0.49 & $0.00 \%$ & 0.49 & 88 \\
\hline Morgan Hill & 0.10 & 0.14 & 0.14 & 0.38 & $0.00 \%$ & 0.38 & 89 \\
\hline Hillcrest Avenue & -- & 0.31 & 0.31 & 0.63 & $44.17 \%$ & 0.39 & 90 \\
\hline Brentwood & -- & 0.12 & 0.12 & 0.24 & $26.23 \%$ & 0.18 & 91 \\
\hline Byron & -- & 0.08 & 0.08 & 0.17 & $0.12 \%$ & 0.17 & 92 \\
\hline Gilroy & 0.03 & 0.04 & 0.04 & 0.12 & $35.13 \%$ & 0.08 & 93 \\
\hline
\end{tabular}




\section{REFERENCES}

\section{Chapter 1}

Bay Area Rapid Transit District. (2008). BART Fiscal Year Weekday Average Exits. Accessed 30 September 2009 from http://www.bart.gov/docs/station_exits_FY.pdf

Peninsula Corridor Joint Powers Board (2008). Key Findings: February 2008 Caltrain Annual Passenger Counts. Accessed 30 September 2009 from http://www.caltrain.com/pdf/annual_ridership_counts/2008_Caltrain_Ridership_Counts.p df.

San Francisco Bay Area Metropolitan Transportation Commission. (2008). Bay Area 2035 Regional Transportation Plan. Accessed 30 May 2008 from http://www.mtc.ca.gov/planning/2035_plan/.

U.S. Census Bureau (2009). ACS Demographic and Housing Estimates, 2005-2007: San Jose-San Francisco-Oakland Combined Statistical Area. Retrieved July 8, 2009 from http://factfinder.census.gov/servlet/DatasetMainPageServlet?_program=ACS\&_submenu $\underline{\mathrm{Id}=\& \text { \& lang=en\&_ts. }}$

\section{Chapter 2}

American Public Transportation Association. (2007). Public Transportation Fact Book. Washington, DC: Author.

American Public Transportation Association. (2008). Transit Savings Report. Washington, DC: Author.

Aten, B, and Hewings, J. (1995). Transportation and Energy. In S. Hanson (ed.) The Geography of Urban Transportation, $2^{\text {nd }}$ ed. (Chapter 14). New York: Guildford Press.

Blumberg, E., and Ong, P. (1998). Job Accessibility and Welfare Usage: Evidence from Los Angeles. Journal of Policy Analysis and Management (17)4, 639-657.

Burchell, R and Mukherji S. (2003). Conventional Development versus Managed Growth: The Costs of Sprawl. American Journal of Public Health, 93(9), 1534-1540.

Bureau of Labor Statistics. (2007). Consumer Expenditure Survey. Accessed 25 May 2008 from http://www.bls.gov/cex/.

Bureau of Transportation Statistics. (2006). National Transportation Statistics. Accessed 30 April 2008 from http://www.bts.gov/publications/national_transportation_statistics/2006/index.html. 
Cervero, R. (1999). The Transit Metropolis: A Global Inquiry. Washington, DC: Island Press.

Cervero, R. (2000). Transport and Land Use: Key Issues in Metropolitan Planning and Smart Growth. University of California Transportation Center, 436.

Cervero, R., Tsai, Y-H., Dibb, J., Kluter, A., Nuworsoo, C., Petrova, I., Pohan, M. R., Wachs, M., and Deakin, E. (2002). Reverse Commuting and Job Access in California: Markets, Needs and Policy Prospects; Institute of Transportation Studies. University of California at Berkeley, Institute of Transportation Studies Research Report, 2002-7.

Daisa, J (2004). Traffic, Parking, and Transit-Oriented Development. In H. Dittmar and G Ohland (Ed.), The New Transit Town: Best Practices in Transit Oriented Development (pp. 113-130). Washington, DC: Island Press

Dittmar, H, Belzer, D, and Autler, G (2004). An Introduction To Transit-Oriented Development. In H. Dittmar and G Ohland (Ed.), The New Transit Town: Best Practices in Transit Oriented Development (pp. 1-18). Washington, DC: Island Press

Dittmar, H, and Poticha, S (2004). Defining Transit-Oriented Development: The New Regional Building Block. In H. Dittmar and G Ohland (Ed.), The New Transit Town: Best Practices in Transit Oriented Development (pp. 19-41). Washington, DC: Island Press

Energy Information Administration. (2008). Annual Energy Review 2007. Accessed July 10, 2008 from http://www.eia.doe.gov/aer/.

Energy Information Administration. (2009). Short Term Energy Outlook. Washington, Accessed 30 May 2009 from http://www.eia.doe.gov/steo.

Federal Highway Administration. (2009). Traffic Volume Trends - June 2009. Accessed 15 July 2009 from http://www.fhwa.dot.gov/ohim/tvtw/tvtpage.cfm.

Levine, J, Inam, A, and Torng, G-W. (2005). A Choice-Based Rationale for Land Use and Transportation Alternatives: Evidence from Boston and Atlanta. Journal of Planning Education and Research, 24(3), 317-330.

San Francisco Bay Area Metropolitan Transportation Commission. (2005). The Journey To Work In The San Francisco Bay Area. Accessed 20 June 2008 from http://www.mtc.ca.gov/maps_and_data/datamart/census/datasum.htm

San Francisco Metropolitan Transportation Commission. (2007). Bay Area Transportation 2035 Poll. Accessed 10 November 2007 from http://www.mtc.ca.gov/planning/2035_plan/poll.htm. 
San Francisco Baty Area Metropolitan Transportation Commission. (2008). Bay Area 2035 Regional Transportation Plan. Accessed 30 May 2008 from

http://www.mtc.ca.gov/planning/2035_plan/.

Seigman, P (2003). Is It Really Transit-Oriented Devlopment? Planning, 69(5), 17.

Tumlin, J, and Millard-Ball, A. (2003). How To Make Transit Oriented Development Work. Planning, 69(5), 14-19.

\section{Chapter 3}

Bay Area Rapid Transit District. (2008). BART Fiscal Year Weekday Average Exits. Accessed 30 September 2009 from http://www.bart.gov/docs/station_exits_FY.pdf

Peninsula Corridor Joint Powers Board (2008). Key Findings: February 2008 Caltrain Annual Passenger Counts. Accessed 30 September 2009 from http://www.caltrain.com/pdf/annual_ridership_counts/2008_Caltrain_Ridership_Counts.p df.

San Francisco Bay Area Metropolitan Transportation Commission (1997). Travel Demand Models for the San Francisco Bay Area (BAYCAST-90) - Technical Summary. Accessed 25 August 2007 from http://www.mtc.ca.gov/maps_and_data/datamart/forecast/table3.htm.

\section{Chapter 4}

Healey, J. (2005). Association Between Variables Measured at the Ordinal Level. In Statistics: A Tool for Social Resarach (pp. 361-392). Belmont, CA: Thomson Wadsworth Messenger, T. and Ewing, R. (1996). “Transit-Oriented Development in the Sun Belt.” Transportation Research Record, 1996-1552.

\section{Chapter 5}

Cervero, R., Castellanos, C., Rich, K., and Sarosa, W. (1996). "BART at 20 Series: Land Use and Development Impacts”. University of California Transportation Center, 308. 